\title{
Transactions of the Zoological Society of London
}

An Index to the Artists, 1835-1936

Nina J. Root and Bryan R. Johnson 


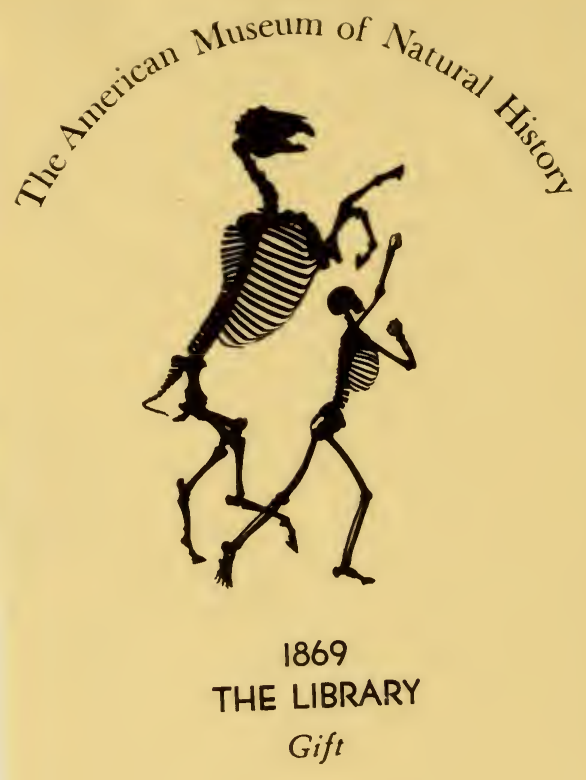

Nina J. Root 


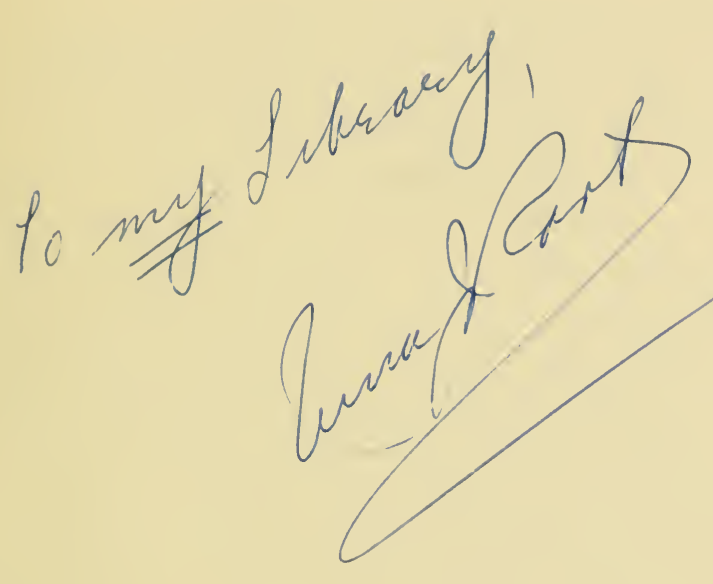





\section{TRANSACTIONS OF THE ZOOLOGICAL SOCIETY OF LONDON AN INDEX TO THE ARTISTS 1835-1936}




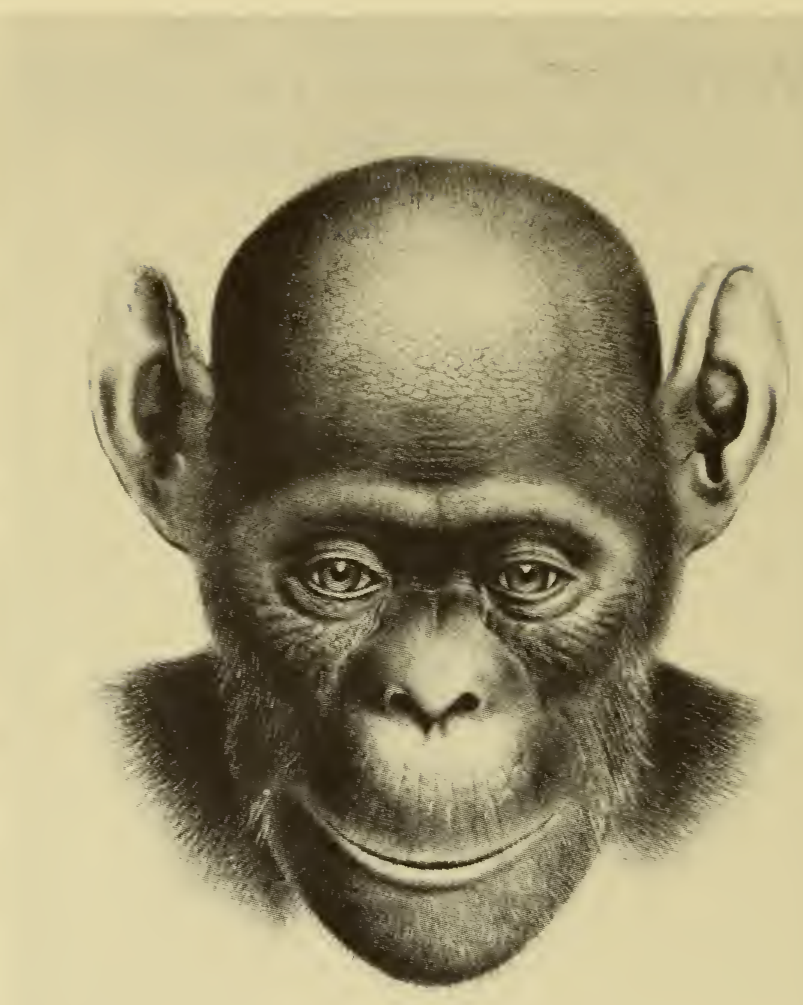

"Head of Troglodytes calvus, Front View" (J. Smit, 13: Plate 20)

AMNH Library Collections 


\title{
TRANSACTIONS OF THE ZOOLOGICAL SOCIETY OF LONDON AN INDEX TO THE ARTISTS 1835-1936
}

\author{
compiled by \\ Nina J. Root \\ and \\ Bryan R. Johnson
}

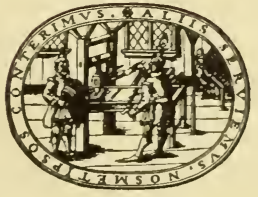

Garland Publishing, Inc. • New York \& London 1986 
(C) 1986 Nina J. Root and Bryan R. Johnson

All rights reserved

\section{Library of Congress Cataloging-in-Publication Data}

Root, Nina J.

Transactions of the Zoological Society of London.

(Garland reference library of the humanities ;

vol. 697)

1. Transactions of the Zoological Society of

London-Illustrations-Indexes. 2. Zoological artists-

Indexes. 3. Zoological illustrations-Indexes.

I. Johnson, Bryan R., 1956- . II. Title.

III. Title: Index to the artists, 1835-1936.

IV. Series: Garland reference library of the humanities ; v. 697.

QL1.Z73 Suppl. 590'.22'2 86-18484

ISBN 0-8240-8548-5 (alk. paper)

Printed on acid-free, 250-year-life paper

Manufactured in the United States of America 
To Obaysch . . .

... and let the world wonder! 

Acknowledgements . . . . . . . . . . . . . . xv

How to Use This Index . . . . . . . . . . . . xvii

ADAMS, Andrew Leith . . . . . . . . . . . . . 1

AHMUD, Shaik Khuleelooddeen . . . . . . . . . 2

B., E.M. • . . . . . . . . . . . . . . . 3

BAYZAND, C.J. •. . . . . . . . . . . . . . 7

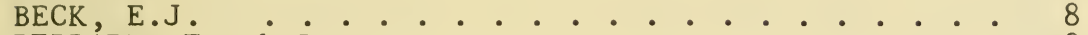

BEDDARD, Frank Émers . . . . . . . . . . . . 9

BELL, Jane S. . . . . . . . . . . . . . . . . 10

BENHAM, William Blaxland Shoppee . . . . . . . 11

BENNETT, George . . . . . . . . . . . . . . 13

BERJEAU, Charles .. . . . . . . . . . . . 14

BERRIDGE, Walter Sydney . . . . . . . . . . 23

BLAIR, David.................. . . . . . 24

BRADY, George Stewardson . . . . . . . . . . . 25

BUDGETT, John Samuel . . . . . . . . . . . . . 34

BUTLER, Arthur Gardiner . . . . . . . . . . 36

CALMAN, William Thomas . . . . . . . . . . 37

CANTOR, Theodore Edward . . . . . . . . . . . 41

CARTER, E.V. . . . . . . . . . . . . . . . 42

CARTER, H.V. . . . . . . . . . . . . . . . 43

CLIFT, William . . . . . . . . . . . . . . . 44

CURTIS, Charles M. . . . . . . . . . . . 45

CURTIS, John . . . . . . . . . . . . . . . 47

DeWILDE, G.R. . . . . . . . . . . . . . . . . . 48

DICKES, William . . . . . . . . . . . . 50

DINKEL, Joseph . . . . . . . . . . . . . 51

EDWARDS, James . . . . . . . . . . . . . . 54

ERXLEBEN, James . . . . . . . . . . . . . 57

FAWCETT, Lt. Col. J. Malcolm . . . . . . . . 94

FLOWER, Sir William Henry . . . . . . . . . . 97

FORD, George Henry . . . . . . . . . . . . . 98

FROHAWK, Frederick William . . . . . . . . 109

GARNER, Robert ................... . . 112

GEDDES, Sir Patrick . . . . . . . . . . . 113

GOULD, Elizabeth ................. . 114

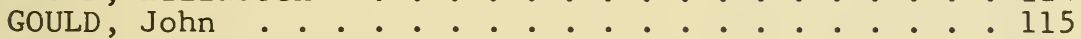

GRANT, Robert Edward .............. . . 117

GREEN, J . . . . . • • . . . . . . . . . 118

GRIESBACH, $\dot{\mathrm{C}}$ arl Ludolf

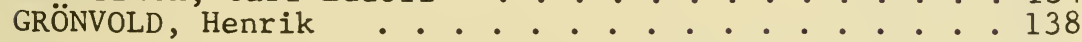


HAMILTON, A. . . . . . . . . . . . . . . 144

HAWKINS, W. . . . . . . . . . . . . . . 145

HICKSON, A.W. . . . . . . . . . . . . . . 146

HICKSON, Sydney John . . . . . . . . . . . . . 147

HIGHLEY, Percy . . . . . . . . . . . . . . 148

HILLS . . . . . . . . . . . . . . . . . . . 149

HILLS, R. . . . . . . . . . . . . . . . 150

HORNE, Charles . . . . . . . . . . . . 151

HOWE, W.M. . . . . . . . . . . . . . . 153

JENNENS, John . . • • . . . . . . . . . . . 154

JONES, Rymer . . . . . . . . . . . . . 155

JONES, Thomas Rymer . . . . . . . . . . . 156

JURY, Julius . . . • • • • • . • . . • • 157

KEULEMANS, John Gerrard . . . . . . . . . . . . 160

KING, L.B. . . . . . . . . . . . . . . . 166

KNIGHT, Horace . . . . . . . . . . . . . . 167

LANKESTER, Sir Edwin Ray . . . . . . . . . . . 173

LEAR, Edward . . . . . . . . . . . . . . . . 174

MACLISE, Joseph . . . . . . . . . . . . . 176

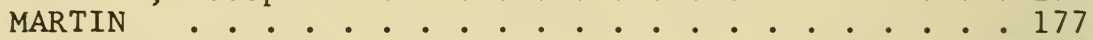

MATTHEWS, M.A.A. . . . . . . . . . . . . 178

MCINTOSH, W.C. ................... . 179

McLEAY, William Sharp . . . . . . . . . . . 181

MINTERN Bros. . . . . . . . . . . . . . . 182

MINTERN, Robert . . . . . . . . . . . . . . 184

MITCHELL, W. . . . . . . . . . . . . . . . . 189

MOORE, Frederic G. . . . . . . . . . . . . 190

MOSS, A. Miles . . . . . . . . . . . . . . 191

MURIE, James . . . . . . . . . . . . . . . . . 193

NEWTON . . . . . . . . . . . . . . . . . . 194

OWEN, Sir Richard . . . . . . . . . . . . . 195

P., C.M. . . . . . . . . . . . . . . . 202

PARKER, M.P. . . . . . . . . . . . . . . . 204

PARKER, Thomas Jeffery . . . . . . . . . . 206

PARKER, William Kitchen . . . . . . . . . . 2 ZUY

PURKISS, W. . . . . . . . . . . . . . . . 220

RHODES, M. . . . . . . . . . . . . . . 223

RICHTER, Henry Constantine . . . . . . . . . 224

ROBINSON, Edward William . . . . . . . . . 225

ROBINSON, F. . . . . . . . . . . . . . . . 226

ROBSON, Guy Coburn . . . . . . . . . . . . 227

ROWE, W.M. . . . . . . . . . . . . . . . 228

RÜPPELL, Edward . . . . . . . . . . . . . . 229

SCHARF, George . . . . . . . . . . . . . 230

SCHARF, Henry . . . . . . . . . . . . . 236

SCHARF, W. . . . . . . . . . . . . . . . . 238

SCHWANWITSCH, B.N. • . . . . . . . . . . 239

SCOTT, John H. . . . . . . . . • . . . . 241

SEARLE, A.H. . . . . . . . . . . . . . 242

SMIT, Joseph •. • • • . . . • • . . • . 247

SMIT, Peter .................. . . 273

SMIT, Pierre Jacques . . . . . . . . . . . . . 276

SMITH, Edgar Albert . . . . . . . . . . . . . 277

SOWERBY, George Brettingham . . . . . . . . . . 278

SOWERBY, George Brettingham, Jr. . . . . . . . 279 
STEBBING, Thomas R.R. . . . . . . . . . . 281

STONE, A. . . . . . . . . . . . . . . . . 287

SUSINI, T. . . . . . . . . . . . . . . . 288

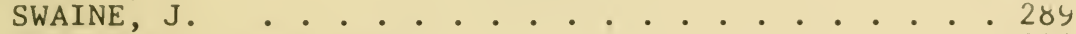

SWINNERTON, Henry Hurd . . . . . . . . . . . 290

TEMPLETON, Robert . . . . . . . . . . . . . 292

TERZI, Amadeo John Enge1 . . . . . . . . . . 293

VAN DER HOEVEN, Jan . . . . . . . . . . . . . 294

VINCENT, Swale .................. . . 295

VISOISF, Djrowcz . . . . . . . . . . . . . 297

VOGEL, F.C. . . . . . . . . . . . . . . . 298

WAGNER, F. . . . . . . . . . . . . . . . . . $29 y$

WATERHOUSE, George Robert . . . . . . . . . . 300

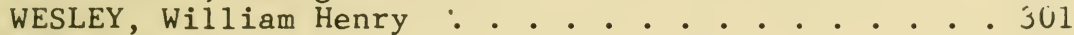

WEST, George . . . . . . . . . . . . . 308

WESTWOOD, John Obadiah . . . . . . . . . . 313

WILLIAMS, Edwin M. • . . . . . . . . . . . 319

WILLIS, G. . . . . . . . . . . . . . . . 321

WILSON, Edwin. . . . . . . . . . . . . . . . 323

WITH, Carl Johannes . . . . . . . . . . . 328

WITTHOOS, Pierre . . . . . . . . . . . . . . 330

WOLF, Joseph . . . . . . . . . . . . . 331

WOODALL, Rev. E.H. . . . . . . . . . . . . 338

WOODWARD, A.M. . . . . . . . . . . . . . 334

WOODWARD, Ellen C. . . . . . . . . . . . . 340

WOODWARD, Gertrude M. . . . . . . . . . . 342

YOUNG . . . . . . . . . . . . . . . . 343

ZEITTER, John Christian . . . . . . . . . . 344

UNSIGNED . . . . . . . . . . . . . . . . 345

Subject index

Amphibians and Reptiles . . . . . . . . 361

Birds .. . . . . . . . . . . . . 364

Fish ................... . 378

Fossils . . . . . . . . . . . . . 386

Insects ................... . . . 390

Beetles ................. . . 393

Butterflies and Moths . . . . . . . . . 347

Invertebrates. . . . . . . . . . . . . 411

Shells... . . . . . . . . . . . 429

Mammals . . . . . . . . . . . . . . . 432 



\section{PLATES}

"Head of Troglodytes calvus, Front View"

(J. Smit, 13: Plate 20). . . . . frontispiece opposite page

Macheirhamphus alcinus (Wolf, 6: Plate 29). . . 56 Apteryx australis (Gould, J., 1: Plate 10). . . 113 Apteryx australis (Unsigned, 1: Plate 10) . . . . 114 Camelopardalis giraffa

(Hills, 3: Plate 1). . . . . . . . . 150

Syonium albitarse (Wolf, 4: Plate 60) . . . . . 202 Didus?; Bernicla ruficollis

(Witthoos, 6: Plate 62). . . . . . . . 246

Rhinoceros unicornis (Wolf, 9: Plate 95). •. . . 300 Dendrocilla leucogastra (Unsigned, 1: Plate 12) • . 344 



\section{PREFACE}

One thing that soon becomes apparent to anyone who works in a natural history library is the wealth of illustrations which have been used in conjunction with scientific publications. Eighteenth-

and nineteenth-century art and science are so closely related in the zoological fields that it becomes difficult to separate the two; one could no more imagine the great zoological journals without their plates than a zoo without the animals.

Important zoological illustrations are part of the history of the science, but it is still difficult to gain access to them through standard bibliographies. Books and articles on the history of natural history art provide scattered information, but a great deal of bibliographical work remains to be done. It was for this reason that we undertook to index the artists who created the plates in the publications of the Zoological Society of London. Our previous work, on the Proceedings, along with the current volume, should provide some aid to researchers who wish to examine the plates in the publications of the Society published before the advent of totally photographic processes. We hope that others will continue the work we have begun and create similar indexes for the many journals which remain. The fields of natural history, librarianship and printing history will all benefit from such work.

It would be pleasant to state that, having compiled one such index, this one was easier to bring together. It would be pleasant, but not entirely true. Each publication, with its own particular assortment of plates, presents its own problems. Working through these problems and finding what we hope are the most appropriate solutions is the most satisfying aspect of compiling this Index (apart, of course, from actually finishing it). These challenges and the pleasure of working with the outstanding illustrations in the Transactions have made the process of compiling this work a satisfying experience for us. 



\section{ACKNOWLEDGEMENTS}

We wish to thank Garland Publishing and Gary Kuris for their support. The plates in this work were photographed from originals in the collection of the Department of Library Services in the American. Museum of Natural History by Olivia Bauer and Jackie Beckett of the Photography Studio in the Museum. Phyllis Johnson and Andy Bates are also thanked for putting up, for a second time, with the turmoil that accompanied the compilation of this work. 

HOW TO USE THIS INDEX

Each plate published in the Transactions of the Zoological Society of London from volume 1 (1835) through volume 21 (1916-1936) has been bibliographically described in this work. Photographic process plates, maps, and diagrams have not been included. Arranged by artist, the citations are listed chronologically within each artist's section.

A subject index of common and scientific names as cited for the thousands of species depicted in these plates is provided at the end of this work.

\section{The Citations}

Each citation is composed of the following elements: date and plate number, title of plate (if given), the subject of the plate, a description of and notes on the plate and a citation for the article which the plate illustrates.

For titled plates (other than those simply listing the scientific name of the species depicted), this title has been given in the citation, in quotes, following the number of the plate.

The scientific names of the species depicted in the plate are listed, in bold face, as cited, and in the same order as that found in the description of the plate published with the article. The names may not conform with current usage.

The description and notes section of the citation indicates if the plate is an engraving, a lithograph (i.e., uncolored), a hand-colored lithograph, a chromolithograph or the product of another process. Even if the method of printing the plate is a photomechanical process, if the original work so reproduced was created by a person, it is included in this work. The name of the printer is also given. 
For those plates where the artist's name is listed without qualification, or is simply followed by the note "del." (i.e., delineator), no note is given. Any other permutation of a proper name is noted as "plate signed..." followed by a transcription of the form on the plate. This note may include the names of co-artists and/or lithographers. Cross-references have been provided when more than one artist created a plate, with the artist whose name is listed first having precedence. Cross-references are not provided for lithographers.

The note "signed" concerns those plates in which the illustration itself bears the signature or monogram of the artist. This note should not be confused with "plate signed" which concerns the names presented on the margin of the plate.

Finally, the accompanying article is cited including author, title, year and pagination of the article (or articles) for which the plate was created.

\section{The Subject Indexes}

The scientific names listed in the citations for the plates have been divided into several major taxonomic groups: amphibians and reptiles; birds; fish; fossils (which are also listed in the other sections of the subject index); insects (including separate sub-groups of beetles and butterflies and moths); invertebrates (with a sub-section for shells); and mammals.

At the beginning of most of these subject index sections, some common names are also listed. These common names are only the most obvious, either from the title of the plate or the title or text of the article. These sections of the subject indexes are not comprehensive and should be used only as a quick finding aid. For those users who wish only to find the citations for plates depicting a monkey, pheasant or salmon, this should usually be sufficient.

The scientific names provide the most useful and accurate method of finding plates of a particular species. For those users who are unfamiliar with taxonomic name forms, there are many reference works which will provide cross-indexing from common names. A very comprehensive work of this type is Synopsis and classification of living organisms, edited by Sybil P. Parker (New York: McGraw-Hill, I982). It should be remembered, however, that some of the names listed in the subject index may no longer be currently used by zoological taxonomists. Synonomies for some zoological 
taxa are available, and the incidence of type specimens illustrated in the Proceedings greatly increases the user's chances of finding a reference to the original name as given in this Index.

The citations for the plates in the subject index refer to the artist, volume and plate. Unless more than one artist with the same surname created plates for the Transactions, only the surname is used. When there is more than one artist with the same surname (e.g., Joseph, Peter and Pierre Jacques Smit), their initials are used to distinguish among them. At times, when the name was particularly long, the periods after the initials were dropped to allow the citation to be placed within the column. Whenever possible, however, this was avoided. A similar system was used in the Index to the Proceedings.

Finally, mention should be made of the fact that the "Shells" section of the subject index only includes those species for which the shell was illustrated in a plate. Those species for which the animal was depicted are listed in the "Invertebrates" section. 



\section{TRANSACTIONS OF THE ZOOLOGICAL SOCIETY OF LONDON AN INDEX TO THE ARTISTS 1835-1936}





\section{ADANiS, Andrew Leith (1826-1882)}

Volume 6 (1869)

Plate 54 subject: Myoxus melitensis

description and notes: lithograph; printed by M. \& N. Hanhart; plate signed L.A. ad nat. del.; figures shown $4 \mathrm{x}$ natural size

article: Adams, A. Leith. "On a species of dormouse (Myoxus) occuring in the fossil state in

Malta." 6:307-308. 


\section{AHMUD, Shaik Khuleelooddeen}

Volume $8(1874)$

Plate 64

subject: Hylomys peguensis

description and notes: 1ithograph; printed by

Mintern Bros.; plate signed Shaik Khuleelooddeen

Ahmud del. G.H. Ford \& C.L. Griesbach lith.

article: Anderson, John. "On the osteology and

dentition of Hylomys." 8:453-467. 


$$
\text { B., E.M. }
$$

\section{Volume $10(1879)$}

\section{Plate 3: "Felidae, Canis, Meles"}

subject: Felidae pardus; Felidae pardina;

Felidae caligata; Canis vulpes; Meles taxus

description and notes: lithograph; printed by $W$.

West; plate signed E.M.B. \& Dinkel del., Linkel

lith.

article: Busk, George. "On the ancient or

Quaternary fauna of Gibraltar, as exemplified in

the mammalian remains of the ossiferous

breccia." 10:53-136.

Plate 5

subject: Ursus arctos

description and notes: 1ithograph; printed by $W$.

West; plate signed E.M.B. del., Dinkel lith.

article: Busk, George. "On the ancient or

Quaternary fauna of Gibraltar, as exemplified in

the mammalian remains of the ossiferous

breccia." 10:53-136.

\section{Plate 7}

subject: Equus caballus

description and notes: lithograph; printed by $W$.

West; plate signed E.M.B. del., Dinkel lith.

article: Busk, George. "On the ancient or

Quaternary fauna of Gibraltar, as exemplified in

the mammalian remains of the ossiferous

breccia." 10:53-136.

\section{Plate 8}

subject: Equus caballus

description and notes: lithograph; printed by $W$.

West; plate signed E.M.B. del. et lith.

article: Busk, George. "On the ancient or

Quaternary fauna of Gibraltar, as exemplified in

the mammalian remains of the ossiferous

breccia." 10:53-136. 
Plate 9

subject: Equus caballus

description and notes: lithograph; printed by $W$.

West; plate signed E.M.B. del. et lith.

article: Busk, George. "On the ancient or

Quaternary fauna of Gibraltar, as exemplified in

the mammalian remains of the ossiferous

breccia." 10:53-136.

Plate 10

subject: Rhinoceros hemitoechus

description and notes: lithograph; printed by $W$. West; plate signed E.M.B. del., G. West lith. article: Busk, George. "On the ancient or

Quaternary fauna of Gibraltar, as exemplified in the mammalian remains of the ossiferous

breccia." 10:53-136.

Plate 11

subject: Rhinoceros hemitoechus

description and notes: lithograph; printed by $W$.

West; plate signed E.M.B. del., Dinkel lith.

article: Busk, George. "On the ancient or

Quaternary fauna of Gibraltar, as exemplified in

the mammalian remains of the ossiferous

breccia." 10:53-136.

Plate 12

subject: Rhinoceros hemitoechus

description and notes: lithograph; printed by $W$.

West; plate signed E.M.B. del., G. West lith.

article: Busk, George. "On the ancient or

Quaternary fauna of Gibraltar, as exemplified in

the mammalian remains of the ossiferous

breccia." 10:53-136.

Plate 13

subject: Rhinoceros hemitoechus

description and notes: lithograph; printed by $W$.

West; plate signed E.M.B. del., G. West lith. article: Busk, George. "On the ancient or

Quaternary fauna of Gibraltar, as exemplified in

the mammalian remains of the ossiferous

breccia." 10:53-136.

Plate 14

subject: Rhinoceros hemitoechus

description and notes: lithograph; printed by $W$. West; plate signed E.M.B. del., Linkel lith.; double-page plate

article: Busk, George. "On the ancient or

Quaternary fauna of Gibraltar, as exemplified in

the mammalian remains of the ossiferous

breccia." 10:53-136. 
Plate 15

subject: Rhinoceros hemitoechus

description and notes: lithograph; printed by $W$.

West; plate signed E.M.B. del., G. West lith.

article: Busk, George. "On the ancient or

Quaternary fauna of Gibraltar, as exemplified in

the mammalian remains of the ossiferous

breccia." 10:53-136.

Plate 16

subject: Rhinoceros hemitoechus

description and notes: lithograph; printed by $W$.

West; plate signed E.M.B. del., Geo. West lith.

article: Busk, George. "On the ancient or

Quaternary fauna of Gibraltar, as exemplified in

the mammalian remains of the ossiferous

breccia." 10:53-136.

Plate 17

subject: Rhinoceros hemitoechus

description and notes: lithograph; printed by $W$.

West; plate signed E.M.B. del., Geo. West lith.

article: Busk, George. "On the ancient or

Quaternary fauna of Gibraltar, as exemplified in

the mammalian remains of the ossiferous

breccia." 10:53-136.

Plate 18

subject: Rhinoceros hemitoechus; Equus caballus; Bos

description and notes: lithograph; printed by $W$.

West; plate signed E.M.B. del., Dinkel lith.

article: Busk, George. "On the ancient or

Quaternary fauna of Gibraltar, as exemplified in

the mammalian remains of the ossiferous

breccia." 10:53-136.

Plate 19

subject: Cervus dama

description and notes: lithograph; printed by $W$.

West; plate signed E.M.B. del., Dinkel lith.

article: Busk, George. "On the ancient or

Quaternary fauna of Gibraltar, as exemplified in

the mammalian remains of the ossiferous

breccia." 10:53-136.

Plate 21

subject: Cervus elephus var. barbarus; Cervus elephus

description and notes: lithograph; printed by $W$. West; plate signed E.M.B. del., Dinkel lith. article: Busk, George. "On the ancient or

Quaternary fauna of Gibraltar, as exemplified in

the mammalian remains of the ossiferous

breccia." 10:53-136. 


\section{Plate 23}

subject: Ibex

description and notes: 1ithograph; printed by W. West; plate signed E.M.B. del., Dinkel lith. article: Busk, George. "On the ancient or Quaternary fauna of Gibraltar, as exemplified in the mammalian remains of the ossiferous breccia." 10:53-136.

Plate 24

subject: Ibex

description and notes: 1ithograph; printed by $W$. West; plate signed E.M.B. del., Dinkel lith. article: Busk, George. "On the ancient or Quaternary fauna of Gibraltar, as exemplified in the mammalian remains of the ossiferous breccia." 10:53-136.

\section{Plate 25}

subject: Ibex

description and notes: lithograph; printed by $W$. West; plate signed E.M.B. del., Dinkel lith. article: Busk, George. "On the ancient or

Quaternary fauna of Gibraltar, as exemplified in the mammalian remains of the ossiferous breccia." 10:53-136.

\section{Plate 26}

subject: Ibex

description and notes: lithograph; printed by $W$. West; plate signed E.M.B. del., Dinkel lith. article: Busk, George. "On the ancient or

Quaternary fauna of Gibraltar, as exemplified in the mammalian remains of the ossiferous breccia." 10:53-136. 
BAYZAND, C.J.

Volume 14 (1898)

Plate 2

subject: Lepidosiren paradoxa; Protopterus annectens

description and notes: lithograph; printed by Mintern Bros.; plate signed Bayzand del. ad nat., J. Smit lith.; folded plate

article: Lankester, E. Kay. "On the Lepidosiren of Paraguay, and on the external characters of Lepidosiren and Protopterus." 14:11-24. 
BECK, E.J. (Miss)

Volume 11 (1885)

Plate 77: "Anatomy of Scorpio"

subject: Scorpio (Buthus); Scorpio (Androctonus)

description and notes: hand-colored lithograph;

printed by Hanhart; plate signed E.J. Beck del., C. Berjeau lith.

article: Lankester, E. Ray, W.B.S. Benham and E.J.

Beck. "On the muscular and endoskeletal systems

of Limulus and Scorpio; with some notes on

the anatomy and generic characters of scorpions." 11:311-384.

Plate 78: "Anatomy of Scorpio"

subject: Scorpio (Buthus); Scorpio (Androctonus)

description and notes: hand-colored lithograph;

printed by Hanhart; plate signed E.J. Beck del.,

C. Berjeau lith.

article: Lankester, E. Ray, W.B.S. Benham and E.J. Beck. "On the muscular and endoskeletal systems of Limulus and Scorpio; with some notes on the anatomy and generic characters of scorpions." 11:311-384.

Plate 79: "Anatomy of Scorpio"

subject: Scorpio (Buthus); Scorpio (Italicus)

description and notes: hand-colored lithograph;

printed by Hanhart; plate signed E.J. Beck del., C. Berjeau lith.

article: Lankester, E. Ray, W.B.S. Benham and E.J. Beck. "On the muscular and endoskeletal systems of Limulus and Scorpio; with some notes on the anatomy and generic characters of scorpions." 11:311-384. 
BEDDARD, Frank Emers (1858-1925)

\section{Volume 12 (1890)}

\section{Plate 14}

subject: Microchaeta rappi

description and notes: hand-colored lithograph;

printed by Mintern Bros.; plate signed F.E.E. del., P. Smit lith.

article: Beddard, Frank E. "On the anatomy and systematic position of a gigantic earthworm (Microchaeta rappi) from the Cape Colony." $12: 63-76$.

Plate 15

subject: Microchaeta rappi

description and notes: hand-colored lithograph; printed by Mintern Bros.; plate signed F.E.B. del., P. Smit lith.; shows anatomical details article: Beddard, Frank E. "On the anatomy and systematic position of a gigantic earthworm (Microchaeta rappi) from the Cape Colony." $12: 63-76$. 
BELL, Jane S.

Volume 1 (1835)

Plate 17

subject: Bradypus tridactylus

description and notes: lithograph; printed by $C$.

Hullmandel; plate signed G. Scharf lithog., Jane S. Bell delt.; plate shows vertebrae and ribs of species only

article: Bell, Thomas. "Observations on the neck of the three-toed sloth, Bradypus tridactylus, Linn." $1: 113-116$. 
BENHAM, William Blaxland Shoppee (1860-1950)

Volume 11 (1885)

Plate 72: "Anatomy of Limulus" subject: Limulus

description and notes: hand-colored lithograph; printed by Hanhart; plate signed W.B.S. Benham del., C. Berjeau lith.

article: Lankester, E. Ray, W.B.S. Benham and E.J. Beck. "On the muscular and endoskeletal systems of Limulus and Scorpio; with some notes on the anatomy and generic characters of scorpions." 11:311-384.

Plate 73: "Anatomy of Limulus"

subject: Limulus

description and notes: hand-colored lithograph; printed by Hanhart; plate signed W.B.S. Benham del., C. Berjeau lith.

article: Lankester, E. Ray, W.B.S. Benham and E.J. Beck. "On the muscular and endoskeletal systems of Limulus and Scorpio; with some notes on the anatomy and generic characters of scorpions." 11:311-384.

Plate 74: "Anatomy of Limulus"

subject: Limulus

description and notes: hand-colored lithograph; printed by Hanhart; plate signed W.B.S. Benham del., C. Berjeau lith.

article: Lankester, E. Ray, W.B.S. Benham and E.J. Beck. "On the muscular and endoskeletal systems of Limulus and Scorpio; with some notes on the anatomy and generic characters of scorpions." 11:311-384.

Plate 75: "Anatomy of Limulus" subject: Limulus

description and notes: hand-colored lithograph; printed by Hanhart; plate signed W.B.S. Benham del., C. Berjeau lith.

article: Lankester, E. Ray, W.B.S. Benham and E.J. Beck. "On the muscular and endoskeletal systems of Limulus and Scorpio; with some notes on the anatomy and generic characters of scorpions." 11:311-384. 
Plate 76: "Anatomy of Limulus"

subject: Limulus

description and notes: hand-colored lithograph;

printed by Hanhart; plate signed W.B.S. Benham

del., C. Berjeau lith.

article: Lankester, E. Ray, W.B.S. Benham and E.J. Beck. "On the muscular and endoskeletal systems of Limulus and Scorpio; with some notes on the anatomy and generic characters of scorpions." 11:311-384. 
BENNETT, George (1804-1893)

Volume 1 (1835)

Plate 34 subject: Ornithorhynchus paradoxus

description and notes: lithograph; printed by $C$. Hullmandel; plate signed G. Scharf lithog., G. Bennett del.

article: Bennett, George. "Notes on the natural history and habits of the Ornithorhynchus paradoxus, Blum." $1: 229-258$. 
BERJEAU, Charles [fl. 1877-1892]

Volume 7 (1872)

Plate 2

subject: Galago crassicaudatus [female]

description and notes: lithograph; printed by M. \& N. Hanhart; plate signed C. Eerjeau \& Dr. Murie, del., C. Berjeau lith.; figure shown natural size; shows muscle structure article: Murie, James and St. George Mivart. "On the anatomy of the Lemuroidea." $7: 1-113$.

Plate 3

subject: Galago crassicaudatus

description and notes: lithograph; printed by M. \& N. Hanhart; plate signed C. Berjeau \& Dr. Murie, del., C. Berjeau lith.; shows muscle structure article: Murie, James and St. George Mivart. "On the anatomy of the Lemuroidea." $7: 1-113$.

Plate 4

subject: Galago crassicaudatus

description and notes: lithograph; printed by $M$. \& N. Hanhart; plate signed C. Berjeau \& Dr. Murie, del., C. Berjeau lith.; shows muscle structure article: Murie, James and St. George Mivart. "On the anatomy of the Lemuroidea." 7:1-113.

Plate 5

subject: Galago crassicaudatus

description and notes: lithograph; printed by M. \& $N$. Hanhart; plate signed C. Berjeau \& Dr. Murie, del., C. Berjeau lith.; shows muscle structure article: Murie, James and St. George Mivart. "On the anatomy of the Lemuroidea." 7:1-113.

Plate 6

subject: Galago crassicaudatus

description and notes: 1ithograph; printed by M. \& N. Hanhart; plate signed C. Berjeau \& Dr. Murie, del., C. Berjeau lith.; shows muscle structure article: Murie, James and St. George Mivart. "On the anatomy of the Lemuroidea." 7:1-113. 
Plate 54: "Urino Generative Organs, \&c." subject: Trichecus rosmarus [male]

description and notes: lithograph; printed by $M$. \& $N$. Hanhart; plate signed C. Berjeau del. et lith., J. Murie dir.

article: Murie, James. "Researches upon the anatomy of the Pinnipedia. Part I. On the walrus

(Trichechus rosmarus, Linn.)." 7:411-464.

Plate 55: "Vascular Digestive \& Vocal Organs, \&c." subject: Trichecus rosmarus [male]

description and notes: lithograph; printed by M. \& $N$. Hanhart; plate signed C. Berjeau del. et lith., J. Murie dir.

article: Murie, James. "Researches upon the anatomy of the Pinnipedia. Part I. On the walrus

(Trichechus rosmarus, Linn.)." 7:411-464.

Plate 56

subject: Rhinochetus jubatus; Cancroma cochlearia; Cacatua ducorpsii

description and notes: lithograph; printed by $N_{\text {. }} \&$ N. Hanhart; plate signed C. Berjeau, lith. ad nat., J. Murie dir.; two-page plate

article: Murie, James. "On the dermal and visceral structures of the kagu, sun-bittern, and boatbil1." 7:465-492.

Plate 57

subject: Rhinochetus jubatus; Eurypyga helias;

Cancroma cochlearia

description and notes: lithograph; printed by 11 . \& N. Hanhart; plate signed C. Berjeau, del. et lith., J. Murie dir.

article: Murie, James. "On the cermal and visceral structures of the kagu, sun-bittern, and boatbill." 7:465-492.

Plate 63: "Anal Glands \&c., Hyaena brunnea" subject: Hyaena brunnea [female]

description and notes: lithograph; printed by $M$. \& N. Hanhart; plate signed C. Berjeau del. ad nat.; figure shown natural size

article: Murie, James. "On the female generative organs, viscera, and fleshy parts of Hyaena brunnea, Thunberg." 7:503-512.

Plate 67: "Dorsal Surface Fore \& Hind Flippers" subject: Otaria jubata

description and notes: lithograph; printed by M. \& N. Hanhart; plate signed C. Berjeau del. ad nat., J. Smit lith.; figures shown $1 / 3$ natural size

article: Murie, James. "Researches upon the anatomy of the Pinnipedia. Part II. Descriptive anatomy of the sea-lion (Otaria jubata)." 7:527-596. 

Plate 68: "Perinaeo-Tibial Region \& Soles Hind \& Fore

subject: Otarie jubata

description and notes: lithograph; printed by M. \& N. Hanhart; plate signed C. Berjeau delt., J. Smit lith.; figures shown $1 / 3$ natural size article: Murie, James. "Researches upon the anatomy of the Pinnipedia. Part II. Descriptive anatomy of the sea-lion (Otaria jubata)." 7:527-596.

Plate 69: "Chest Folds, Eye, Ear, Muzzle \& Skin Muscle" subject: Otaria jubata

description and notes: lithograph; printed by $M$. \& $\mathrm{N}$. Hanhart; plate signed C. Berjeau del., J.

Smit lith.

article: Murie, James. "Researches upon the anatomy of the Pinnipedia. Part II. Descriptive anatomy of the sea-lion (Otaria jubata)." 7:527-596.

Plate 70: "Muscles Head, Body, Limbs and Diaphragm" subject: Otaria jubata

description and notes: lithograph; printed by M. \& $\mathrm{N}$. Hanhart; plate signed C. Berjeau del. et lith., J. Murie dir.; three-page folded plate article: Murie, James. "Researches upon the anatomy of the Pinnipedia. Part II. Descriptive anatomy of the sea-lion (Otaria jubata)." 7:527-596.

Plate 71: "Superficial \& Deep Spinal Muscles" subject: Otaria jubata

description and notes: lithograph; printed by M. \& $\mathrm{N}$. Hanhart; plate signed C. Berjeau del. et lith., J. Murie dir.

article: Murie, James. "Researches upon the anatomy of the Pinnipedia. Part II. Descriptive anatomy of the sea-lion (Otaria jubata)." 7:527-596.

Plate 72: "Deep Flexors \& Ligaments Forelimb \&c." subject: Otaria jubata

description and notes: lithograph; printed by M. \& $\mathrm{N}$. Hanhart; plate signed C. Berjeau del. et lith., J. Murie dir.

article: Murie, James. "Researches upon the anatomy of the Pinnipedia. Part II. Descriptive anatomy of the sea-lion (Otaria jubata)." 7:527-596.

Plate 73: "Abdomino-Lumbar Regions \& Hind Legs Muscles Ligaments \&c."

subject: Otaria jubata

description and notes: lithograph; printed by $M$. \& $\mathrm{N}$. Hanhart; plate signed C. Berjeau del. et lith., J. Murie dir.; two-page plate article: Murie, James. "Researches upon the anatomy of the Pinnipedia. Part II. Descriptive anatomy of the sea-1ion (Otaria jubata)." 7:527-596. 
Volume 8 (1874)

Plate 21: "Myology Superficial \& Deep Layers" subject: Manatus americanus [female]

description and notes: hand-colored lithograph;

printed by $M$. \& N. Hanhart; plate signed $C$.

Berjeau del. et lith.; figures shown $1 / 4$ natural size

article: Murie, James. "On the form and structure of the manatee (Manatus americanus)."

$8: 127-202$.

Plate 22: "Limb Muscles Mouth \& Foetal Sku11" subject: Manatus americanus

description and notes: 1ithograph; printed by M. \& N. Hanhart; plate signed C. Berjeau lith., J. Murie

article: Murie, James. "On the form and structure of the manatee (Manatus americanus)."

$8: 127-202$.

Plate 23: "Alimentary Canal"

subject: Manatus americanus

description and notes: lithograph; printed by M. \& N. Hanhart; plate signed C. Berjeau lith. ad nat., J. Murie dir.

article: Murie, James. "On the form and structure of the manatee (Manatus americanus)."

$8: 127-202$.

Plate 24: "Heart, Plexuses Neck \& Auxillary Regions \&c." subject: Manatus americanus

description and notes: hand-colored lithograph; printed by $M$. \& N. Hanhart

article: Murie, James. "On the form and structure of the manatee (Manatus americanus)." $8: 127-202$.

Plate 25: "The Brain Nat. size and Cranial Cavity reduced"

subject: Manatus americanus

description and notes: lithograph; printed by M.\&

N. Hanhart; plate signed Berjeau \& Murie delt.,

C. Berjeau lith.

article: Murie, James. "On the form and structure of the manatee (Manatus americanus)." 8:127-202. 
Plate 26: "Dissections, Viscera, Vascular, Pulmonary \& Generative Organs \&c" subject: Manatus americanus description and notes: hand-colored lithograph; printed by M. \& N. Hanhart; plate signed Berjeau del. et lith.; two-page plate article: Murie, James. "On the form and structure of the manatee (Manatus americanus)." $8: 127-202$.

\section{Plate 30}

subject: Globiocephalus melas [female]

description and notes: 1ithograph; printed by M. \& $N$. Hanhart; plate signed C. Berjeau del. et lith.; figures shown $1 / 13$ natural size article: Murie, James. "On the organization of the caaing whale, Globiocephalus melas." 8:235-301.

Plate 31: "Mouth Cavity \& Hyo Larynceal Apparatus" subject: Globiocephalus mélas

description and notes: hand-colored lithograph; printed by M. \& N. Hanhart

article: Nurie, James. "On the organization of the caaing whale, Globiocephalus melas." 8:235-301.

Plate 32: "Fin Sections, Spiracular Cavities \& Cranial Rete, \&c."

subject: Globiocephalus melas

description and notes: hand-colored lithograph; printed by $M$. \& N. Hanhart

article: Murie, James. "On the organization of the caaing whale, Globiocephalus melas." 8:235-301.

Plate 33: "Alimentary cavities, Glands \& Kidney" subject: Globiocephalus melas

description and notes: lithograph; printed by $M$. \&

N. Hanhart; plate signed C. Berjeau del. et lith. article: Murie, James. "On the organization of the caaing whale, Globiocephalus melas." 8:235-301.

Plate 34: "Folds \& Glands Alimentary Tract \&c." subject: Globiocephalus melas

description and notes: 1ithograph; printed by $M$. \&

N. Hanhart; plate signed C. Berjeau lith. ad nat. article: Murie, James. "On the organization of the caaing whale, Globiocephalus melas." 8:235-301.

Plate 35: "Pulmo-Sanguiferous Structures \& Penis" subject: Globiocephalus melas

description and notes: hand-colored lithograph;

printed by $M$. \& N. Hanhart; plate signed C.

Berjeau del. et lith.

article: Murie, James. "On the organization of the caaing whale, Globiocephalus melas." 8:235-301. 
Plate 36: "Myology. Superficial Layers \& Tendons, Tail" subject: Globiocephalus melas

description and notes: hand-colored lithograph; printed by $M$. \& N. Hanhart

article: Murie, James. "On the organization of the caaing whale, Globiocephalus melas." 8:235-301.

Plate 37: "Myology. Deep Layers Limbs and Blow Hole" subject: Globiocephalus melas

description and notes: hand-colored lithograph; printed by $M$. \& N. Hanhart; plate signed $C$. Berjeau del. et lith.

article: Murie, James. "On the organization of the caaing whale, Globiocephalus melas." 8:235-301.

Plate 38: "Generative Organs [female] Pelvic Bones and Muscles"

subject: Globiocephalus melas

description and notes: hand-colored lithograph; printed by $M$. \& N. Hanhart

article: Murie, James. "On the organization of the caaing whale, Globiocephalus melas." 8:235-301.

Plate 77: "Otaria jubata. Skeleton and Crania at Different Ages, \&c."

subject: Otaria jubata

description and notes: 1ithograph; printed by M. \& N. Hanhart; plate signed C. Berjeau del. et lith.; double-page plate

article: Murie, James. "Researches upon the anatomy of the Pinnipedia. (Part III.) Lescriptive anatomy of the sea-lion (Otaria jubata)." $8: 501-582$.

Plate 78: "Brain of Otaria jubata" subject: Otaria jubata

description and notes: hand-colored lithograph; printed by $M$. \& N. Hanhart; plate signed C. Berjeau del. et lith.

article: Murie, James. "Researches upon the anatomy of the Pinnipedia. (Part III.) Descriptive anatomy of the sea-lion (Otaria jubata)." $8: 501-582$.

Plate 79: "Sensory and Vascular Organs. Otaria jubata" subject: Otaria jubata

description and notes: hand-colored lithograph;

printed by M. \& N. Hanhart; plate signed Burjeau $\&$ Murie del., C. Berjeau lith.

article: Murie, James. "Researches upon the anatomy of the Pinnipedia. (Part III.) Descriptive anatomy of the sea-lion (Otaria jubata)." 8:501-582. 
Plate 80: "Organs of Deglution \& Voice. Otaria jubata" subject: Otaria jubata

description and notes: hand-colored lithograph;

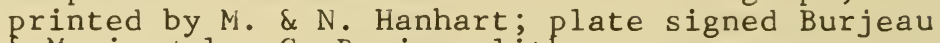
\& Murie del., C. Berjeau lith.

article: Murie, James. "Kesearches upon the anatomy of the Pinnipedia. (Yart III.) Descriptive anatomy of the sea-lion (Otaria jubata)." $8: 501-582$.

Plate 81: "Digestive \& Urinary Organs. Otaria jubata" subject: Otaria jubata

description and notes: hand-colored lithograph; printed by M. \& N. Hanhart; plate signed C. Burjeau del., J. Smit lith.

article: Murie, James. "Researches upon the anatomy of the Pinnipedia. (Part III.) Descriptive anatomy of the sea-lion (Otaria jubata)." $8: 501-582$.

Plate 82: "Liver \& Generative Organs. Otaria jubata" subject: Otaria jubata

description and notes: hand-colored lithograph; printed by $M$. \& N. Hanhart; plate signed C. Burjeau del. et lith.

article: Murie, James. "Researches upon the anatomy of the Pinnipedia. (Part III.) Descriptive anatomy of the sea-lion (Otaria jubata)." $8: 501-582$.

Volume 11 (1885)

Plate 5: "Attitudes of Manatee in Tank" subject: Manatus americanus

description and notes: lithograph; printed by Hanhart

article: Murie, James. "Further observations on the manatee." $11: 19-48$.

Plate 6: "Different Aspects, Head, Muzzle \& Tail of Manatee Alive \& Dead"

subject: Manatus americanus

description and notes: lithograph; printed by Hanhart

article: Murie, James. "Further observations on the manatee." $11: 19-48$. 
Plate 7: "Manatee Feeding and Views of Dorsum, Mamma \& Perineum"

subject: Manatus americanus

description and notes: lithograph; printed by Hanhart

article: Murie, James. "Further observations on the manatee." $11: 19-48$.

Plate 8: "Manatee: Eye, Sternum, Limb-Muscles, \& Dissection Neck \& Chest, for Cervical Nerves,

subject: Manatus americanus

description and notes: lithograph; printed by Hanhart

article: Nurie, James. "Further observations on the manatee." $11: 19-48$.

Plate 9: "Brain, Nerves \& Bloodvessels of Manatee in Different Aspects"

subject: Manatus americanus

description and notes: hand-colored lithograph; printed by Hanhart; figures shown natural size article: Murie, James. "Further observations on the manatee." $11: 19-48$.

\section{Volume 13 (1895)}

Plate 11

subject: Gerardia savalia

description and notes: lithograph; printed by Hanhart; plate signed Berjeau \& Highley del. et lith.

article: Bell, F. Jeffrey. "Contributions to our knowledge of the antipatharian corals." 13:87-92.

Plate 12

subject: Antipathes robillardi

description and notes: lithograph; printed by $M \& N$ Hanhart; plate signed Berjeau \& Highley del. et lith.

article: Bell, F. Jeffrey. "Contributions to our knowledge of the antipatharian corals." 13:87-92.

Plate 19

subject: Trogontherium cuvieri

description and notes: lithograph; printed by Hanhart; plate signed Berjeau \& Highley del. et lith.

article: Newton, E.T. "On a skull of Trogontherium cuvieri from the forest bed of East Runton, near Cromer." 13:165-175. 
Plate 38

subject: Cidaris curvatispinis

description and notes: lithograph with printed tan back tone; printed by Hanhart; plate signed Berjeau \& Highley del. et lith.; figure shown $2 / 3$ natural size

article: Bell, F. Jeffrey. "Description of a remarkable new sea-urchin of the genus Cidaris from Mauritius." 13:303-304. 
BERRIDGE, Walter Sydney [fl. 1880-1930]

Volume 16 (1903)

Plate 7: "Osteology of Neobalaena marginata" subject: Neobalaena marginata

description and notes: lithograph; printed by

Mintern Bros.; plate signed W.S. Berridge del., J. Smit lith.; figure shown $1 / 10$ natural size; two-page plate

article: Beddard, Frank E. "Contribution towards a knowledge of the osteology of the pigmy whale (Neobalaena marginata)." 16:87-114.

Plate 8: "Osteology of Neobalaena marginata" subject: Neobalaena marginata

description and notes: lithograph; printed by

Mintern Bros.; plate signed W.S. Berridge del., J. Smit lith.

article: Beddard, Frank E. "Contribution towards a knowledge of the osteology of the pigmy whale (Neobalaena marginata)." 16:87-114.

Plate 9: "Osteology of Neobalaena marginata" subject: Neobalaena marginata description and notes: lithograph; printed by Mintern Bros.; plate signed W.S. Berridge del., J. Smit lith.

article: Beddard, Frank E. "Contribution towards a knowledge of the osteology of the pigmy whale (Neobalaena marginata)." 16:87-114. 
BLAIR, David [fl, 1878-1890]

Volume 12 (1890)

Plate 30

subject: Megalapteryx hectori

description and notes: lithograph; printed by M. \&

$\mathrm{N}$. Hanhart; plate signed D. Blair del., on Stone

by $\mathrm{J}$. Erxleben; figures of bones shown natural

size; folded plate

article: Haast, Julius von. "On Megalapteryx hectori, a new gigantic species of Apterygian bird." 12:161-169. 
BRADY, George Stewardson (1832-1921)

\section{Volume 5 (1866)}

Plate 57: "New Marine Ostracoda"

subject: Cytherella pulchra; Cytherella

punctata; Cytherella beyrichi; Cytherella

rugosa; Bairdia bosquetiana; Bairdia

amygdaloides; Bairdia ovata; Bairdia

subdeltoidea; Bairdia fusca; Bairdia

crosskeiana; Jonesia simplex; Cytherideis

maculata; Cytherideis decora

description and notes: 1ithograph; printed by M. \& N. Hanhart; plate signed G.S. Brady delt., Geo. West lith.

article: Brady, George Stewarỏson. "On new or imperfectly known species of marine Ostracoda." $5: 359-393$.

Plate 58: "New Marine Ostracoda"

subject: Cytherideis gracilis; Cytherideis oryza; Cytherideis pulchra; Cytherideis

lata; Cytherideis tigrina; Cytheridea margaritea; Cytheridea curta; Cytheridea papillosa; Cytherideis nobilis; Cytheridea minima; Cytheridea mülleri; Cythere setosa Hunde; Cythere setosa var. hunde; Cytheridea kirkbyi

description and notes: 1ithograph; printed by M. \& N. Hanhart; plate signed G.S. Brady delt., Geo. West 1 ith.

article: Brady, George Stewardson. "On new or imperfectly known species of marine Ostracoda." $5: 359-393$. 
Plate 59: "New Marine Ustracoda"

subject: Cythere jurinei; Cythere jurinei var. costellata; Cythere hodgii; Cythere canaliculata; Cythere oblonga; Cythere mamillata; Cythere producta; Cythere venata; Cythere clathrata var. nuda; Cythere clathrata; Cythere clathrata var. lyrata; Cythere clathrata var. latimarginata; Cythere mutabilis

description and notes: lithograph; printed by $M$. \& N. Hanhart; plate signed G.S. Brady delt., Geo. West lith.

article: Brady, George Stewardson. "On new or imperfectly known species of marine Ostracoda." $5: 359-393$.

Plate 60: "New Marine Ostracoda"

subject: Cythere plicatula; Cythere catenata;

Cythere lactea; Cythere septentrionalis;

Cythere costata; Cythere lactea var. rudis; Cythere pumila; Cythereis batei;

Cythereis subcoronata; Cythereis spinosissima

description and notes: lithograph; printed by $M$. \& N. Hanhart; plate signed G.S. Brady delt., Geo. West lith.

article: Brady, George Stewardson. "On new or imperfectly known species of marine Ostracoda." $5: 359-343$.

Plate 61: "New Marine Ostracoda"

subject: Cythereis cristatella; Cythere pavonia; Cythere pumicosa; Cythereis

lacerata; Cythere normani; Cythere cribriformis; Cythereis fungoides; Cythere scabra Abrolhos; Cythereis militaris; Normania grisea; Normania glabra; Normania affinis; Normania modesta; Normania dorso-tuberculata; Normania avellana

description and notes: 1ithograph; printed by M. \& N. Hanhart; plate signed G.S. Brady del., Geo. West lith.

article: Brady, George Stewardson. "On new or imperfectly known species of marine Ostracoda." $5: 359-393$. 
Plate 62: "New Marine Ostracoda"

subject: Cythere parkeri; Cythere areolata;

Cythere compacta; Cythere latissima;

Cythere rhomboidea; Heterodesmus adamsii;

Cypridina bairdii; Cypridina japonica;

Cypridina elongata

description and notes: 1ithograph; printed by $M$. \&

N. Hanhart; plate signed G.S. Brady delt., W.

West lith.

article: Brady, George Stewardson. "On new or

imperfectly known species of marine Ostracoda."

$5: 359-393$.

Volume 10 (1879)

Plate 62: "Fossil Ostracoda"

subject: Cytheridea papillosa var.; Cytherella

parallela; Cytheridea pinguis; Cytheridea

mülleri [female and male]; Cytherella nodosa;

Cytherella elliptica

description and notes: lithograph; printed by M. \&

N. Hanhart; plate signed G.S.B. del., W. Purkiss lith.

article: brady, George Stewardson. "A monograph of the Ostracoda of the Antwerp Crag." 10:379-409.

Plate 63: "Fossil Ostracoda"

subject: Cythere tarentina; Cytherideis(?)

lithodomoides; Cytherideis recta;

Pontocypris propinqua; Paracypris polita;

Pontocypris faba [female and male]; Bairdia ovi formis

description and notes: lithograph; printed by $M$. \& N. Hanhart; plate signed G.S.B. del., W. Purkiss lith.

article: Brady, George Stewardson. "A monograph of the Ostracoda of the Antwerp Crag." 10:379-409.

Plate 64: "Fossil Ostracoda"

subject: Cythere oedichilus; Paradoxostoma

ensiforme; Cythere cicatricosa; Cythere

cribrosa?; Cythere petrosa; Cythere

plicatula; Cythere wetherellii; Cythere

latimarginata; Cythere limicola

description and notes: lithograph; printed by $M . \&$ N. Hanhart; plate signed G.S.B. del., W. Purkiss lith.

article: Brady, George Stewardson. "A monograph of the Ostracoda of the Antwerp Crag." 10:379-409. 
Plate 65: "Fossil Ostracoda"

subject: Cythere ellipsoidea; Cythere jurinei;

Cythere belgica; Cythere woodiana; Cythere plicata

description and notes: lithograph; printed by $M$. \& N. Hanhart; plate signed G.S.B. del., W. Purkiss lith.

article: Brady, George Stewardson. "A monograph of the Ostracoda of the Antwerp Crag." 10:379-409.

\section{Plate 66: "Fossil Ostracoda"}

subject: Cythere polytrema; Cythere scabropapulosa; Cythere dawsoni?; Cythere trapezia; Cythere acuticosta; Cythere macropora; Cythere cornuta; Xestoleberis depressa

description and notes: lithograph; printed by M. \& N. Hanhart; plate signed G.S.B. del., W. Purkiss lith.

article: brady, George Stewardson. "A monograph of the Ostracoda of the Antwerp Crag." 10:399-409.

Plate 67: "Fossil Ostracoda"

subject: Cythere macropora; Cythere jonesii;

Cythere mucronata; Cythere subcoronata

description and notes: lithograph; printed by M. \&

N. Hanhart; plate signed G.S.B. del., W. Purkiss lith.

article: Brady, George Stewardson. "A monograph of the Ostracoda of the Antwerp Crag." 10:379-409.

Plate 68: "Fossil Ostracoda"

subject: Loxoconcha latissima [female and male];

Loxoconcha bitruncata; Loxoconcha

grateloupiana [male and female]; Loxoconcha variolata

description and notes: lithograph; printed by N. \& N. hanhart; plate signed G.S.B. del., W. Purkiss lith.

article: Brady, George Stewarason. "A monograph of the Ostracoda of the Antwerp Crag." 10:399-409.

Plate 69: "Fossil Ostracoda"

subject: Cytheropteron latissimum; Cytheropteron

pipistrella; Cytheropteron intermedium;

Cytheropteron gradatum; Cytherura broeckiana

[female and male]; Cytheridea cypridioides description and notes: lithograph; printed by M. \&

N. Hanhart; plate signed G.S.E. del., W. Purkiss lith.

article: brady, George Stewardson. "A monograph of the Ostracoda of the Antwerp Crag." 10:379-409. 
Volume $14(1898)$

Plate 15: "Crustaceans of the Group Myodocopa" subject: Cyclasterope hendersoni [female]; Cyclasterope orbicularis [female]; Cypridina(?) armata

description and notes: lithograph; printed by Geo. West \& Sons; plate signed G.S. Brady del., M.P. Parker lith.

article: Brady, G. Stewardson. "A supplementary report on the crustaceans of the group Nyodocopa obtained during the 'Challenger' Expedition, with notes on other new or imperfectly known species." 14:85-100.

Plate 16: "Crustaceans of the Group Myodocopa" subject: Cypridina castanea [female]; Cypridina punctata; Cypridina(?) squamosa;

Philomedes agilis [female]; Philomedes corrugata; Cypridina bairdi; Cypridina danae; Eurypylus petrosus

description and notes: lithograph; printed by Geo. West \& Sons; plate signed G.S. Brady del., M.P. Parker lith.

article: Brady, G. Stewardson. "A supplementary report on the crustaceans of the group Myodocopa obtained during the 'Challenger' Expedition, with notes on other new or imperfectly known species." 14:85-100.

Plate 17: "Crustaceans of the Group Myodocopa" subject: Pleoschisma moroides [male and female]; Sarsiella sculpta; Sarsiella robusta [male]; Sarsiella simplex [female]; Paraconchaecia oblonga [male]; Pseudoconchaecia serrulata [male]

description and notes: lithograph; printed by Geo. West \& Sons; plate signed G.S.'Brady del., M.P. Parker lith.

article: Brady, G. Stewardson. "A supplementary report on the crustaceans of the group Myodocopa obtained during the 'Challenger' Expedition, with notes on other new or imperfectly known species." 14:85-100. 
Plate 43: "Ostracoda from New Zealand"

subject: Asterope australis [male and female]; Asterope grisea [female and male];

Cyclasterope zealandica [female and male]; Cyclasterope ovulum [female]

description and notes: lithograph; printed by Geo. West \& Sons; plate signed G.S. Brady del., Parker \& Percy lith.

article: Brady, G. Stewardson. "On new or imperfectly-known species of Ostracoda, chiefly from New Zealand." 14:429-452.

Plate 44: "Ostracoda from liew Zealand"

subject: Philomedes flexilis [female and male];

Philomedes sculpta [male]; Eupathistoma

natans [male]; Cyclasterope tenera

description and notes: lithograph; printed by Geo. West \& Sons; plate signed G.S. Brady del.,

Parker \& Percy lith.

article: Brady, G. Stewardson. "On new or imperfectly-known species of Cstracoda, chiefly from New Zealand." 14:429-452.

Plate 45: "Ostracoda from New Zealand"

subject: Sarsiella hanseni [female and male]; Sarsiella hispida [female]; Philomedes

flexilis [female]; Asterope quadrata [female and male]; Cypris viridis [female]

description and notes: lithograph; printed by Geo. West \& Sons; plate signed G.S. Brady del., Parker \& Percy lith.

article: Brady, G. Stewardson. "On new or imperfectly-known species of Ostracoda, chiefly from New Zealand." 14:429-452.

Plate 46: "Ostracoda from New Zealand"

subject: Cythere innominata; Loxoconcha punctata [female]; Xestoleberis olivacea [female]; Cytherella eburnea; Xestoleberis compressa [female and male]; Xestoleberis luxata; Cyprinotus flavescens

description and notes: lithograph; printed by Geo. West \& Sons; plate signed G.S. Brady del., Parker \& Percy lith.

article: Brady, G. Stewardson. "On new or imperfectly-known species of Ostracoda, chiefly from New Zealand." 14:429-452. 
Plate 47: "Ustracoda from New Zealand"

subject: Trachyleberis scabrocuneata Lmale and female]; Cythere brunnea [female and male]; Cythere truncula; Trachyleberis scabrocuneata [temale and male]

description and notes: lithograph; printed by leo. West \& Sons; plate signed G.S. Brady del., Parker \& Percy lith.

article: Brady, G. Stewardson. "On new or imperfectly-known species of Ostracoda, chiefly from New Zealand." 14:429-452.

Volume 15 (1901)

Plate 9: "Marine Copepoda of New Zealand" subject: Paracalanus parvus [male];

Clausocalanus furcatus [female and male];

Acartia ensifera [female and male]; Temora

tenuicauda [female and malej; Centropages pectinatus [female]; Peltidium novae-zealandiae [female]

description and notes: lithograph; printed by Geo.

West \& Sons; plate signed G.S. Brady del.,

Parker \& Percy lith.

article: Brady, G. Stewardson. "On the marine Copepoda of New Zealand." 15:31-54.

Plate 10: "Marine Copepoda of New Zealand" subject: Centropages discaudatus [male and

female]; Labidocera cervi [female and male];

Cyclops ewarti [female]; Ectinosoma australe

[female]; Flava crassicornis [female]

description and notes: lithograph; printed by Geo.

West \& Sons; plate signed G.S. Brady del.,

Parker \& Percy lith.

article: Brady, G. Stewardson. "On the marine Copepoda of New Zealand." 15:31-54.

Plate 11: "Marine Copepoda of New Zealand"

subject: Laophonte meinerti [female and male];

Dactylopus hanseni [female and male]; Phroso

gracilis [female]; Thalestris ciliata [female]

description and notes: lithograph; printed by Geo.

West \& Sons; plate signed G.S. Brady del.,

Parker \& Percy lith.

article: Brady, G. Stewardson. "On the marine

Copepoda of New Zealand." 15:31-54. 
Plate 12: "Marine Copepoda of New Zealand" subject: Thalestris australis [female]; Harpacticus glaber [female]; Peltidium novae-zealandiae [female]; Scutellidium plumosum [male and female]; Dactylopus tisboides; Caligus longicaudatus [female]; Artotrogus brevicaudatus

description and notes: lithograph; printed by Geo. West \& Sons; plate signed G.S. Brady del., Parker \& Percy lith.

article: Brady, G. Stewardson. "On the marine Copepoda of New Zealand." 15:31-54.

Plate 13: "Marine Copepoda of New Zealand" subject: Paurocope robusta [femalej; Centromma thomsoni; Entomolepis ovalis; Artotrogus brevicaudatus

description and notes: lithograph; printed by Geo. West \& Sons; plate signed G.S. Brady del., Parker \& Fercy lith.

article: Brady, G. Stewardson. "Cn the marine Copepoda of New Zealand." 15:31-54.

Volume 16 (1903)

Plate 21: "New or Imperfectly-Known Ostracoda" subject: Philomedes debilis [male]; Asterope oculata [female and male]; Pyrocypris americana [female]; Cyclasterope fascigera [male and female]; Cypridina granulosa [female] description and notes: lithograph; printed by Bale $\&$ Danielsson

article: Brady, George Stewardson. "On new or imperfectly-known Ostracoda, chiefly from a collection in the Zoological Museum, Copenhagen." 16:179-210.

Plate 22: "New or Imperfectly-Known Ostracoda" subject: Codonocera cruenta Lmale]; Cypridina insolita [female]; Cypridina foveolata [female]; Cypridinodes favus [female] description and notes: lithograph; printed by Bale $\&$ Danielsson

article: Brady, George Stewardson. "On new or imperfectly-known Ostracoda, chiefly from a collection in the Zoological Museum, Copenhagen." 16:179-210. 
Plate 23: "New or Imperfectly-Known Ostracoda"

subject: Cypridopsis marmorata; Cypris

laetevirens; Cyprinotus dentato-marginatus;

Cypris virens; Cyprinotus fragilis; Cypris flexilis; Sarsiella ornithoides; Asterope lichenoides [male]; Cyclasterope similis [female]

description and notes: lithograph; printed by kale \& Danielsson

article: Brady, George Stewardson. "On new or imperfectly-known Ostracoda, chiefly from a collection in the Zoological Museum, Copenhagen." 16:179-210.

Plate 24: "New or Imperfectly-Known Ostracoda" subject: Conchaecissa cucullata; Euconchaecia chierchiae [male and female]; Cyclasterope brevis [female]; Philomedes sordida [male] description and notes: lithograph; printed by bale $\&$ Danielsson

article: Brady, George Stewardson. "On new or imperfectly-known Ostracoda, chiefly from a collection in the Zoological Museum, Copenhagen." 16:179-210.

Plate 25: "New or Imperfectly-Known Cistracoda" subject: Cythere sicula [male]; Bairdia longisetosa; Cypretta sarsi; Candone1la virescens [female and male]; Candonopsis complanata [female]; Cyprinotus fragilis [female]

description and notes: lithograph; printed by bale \& Danielsson

article: Brady, George Stewardson. "On new or imperfectly-known Ostracoda, chiefly from a collection in the Zoological Museum, Copenhagen." 16:179-210. 
Volume 16 (1903)

Plate 10: "Development of West African Fishes. Protopterus"

subject: Protopterus annectens Ow.

description and notes: chromolithograph?; printed by $E$. Wilson

article: Budgett, J.S. "On the breeding-habits of some West-African fishes, with an account of the external features in development of Protopterus annectens, and a description of the larva of Polypterus lapradei." 16:115-136.

Plate 11: "Development of West African Fishes" subject: Polypterus lapradei Stein; Protopterus annectens OW.; Gymnarchus niloticus Cuv.; Heterotis niloticus Cuv.; Sarcodaces odoë B1.; Hyperopisus bebe Lacép.

description and notes: chromolithograph?; printed by $\mathrm{E}$. Wilson

article: Budgett, J.S. "On the breeding-habits of some West-African fishes, with an account of the external features in development of Protopterus annectens, and a description of the larva of Polypterus lapradei." 16:115-136.

Plate 33: "Structure of the Larval Polypterus" subject: Polypterus

description and notes: chromolithograph; printed by E. Wils on

article: Budgett, J.S. "On the structure of the larval Polypterus." 16:315-346.

Plate 34: "Structure of the Larval Polypterus" subject: Polypterus

description and notes: chromolithograph; printed by E. Wilson

article: Budgett, J.S. "On the structure of the larval Polypterus." 16:315-346. 
Plate 35: "Structure of the Larval Polypterus" subject: Polypterus

description and notes: chromolithograph; printed by E. Wilson

article: Budgett, J.S. "On the structure of the larval Polypterus." 16:315-346. 
BUTLER, Arthur Gardiner (1844-1925)

Volume 9 (1877)

Plate 90: "T'ransformations of Sphingidae"

subject: Lophura hyas Walker [larvae and pupa];

Hemaris hylas Linn. [larva and pupa];

Macroglossa belis Cramer [larva and pupa];

Macroglossa pyrrhosticta Butler [larva];

Macroglossa gilia Herr.-Sch. [larva and pupa];

Acosmeryx anceus Cramer [larva and pupa];

Chaerocampa lewisii Butler [larva and pupa];

Smerinthus tattarinovii Ménétriés [larva]

description and notes: hand-colored lithograph; printed by Mintern Bros.; plate signed A.G.

Butler lith. May 1875

article: Butler, Arthur Gardiner. "Kevision of the heterocerous Lepidoptera of the family Sphingidae." 9:511-644.

Plate 91: "Transformations of Sphingidae"

subject: Chaerocampa oldenlandiae Fabricius

[larva]; Ambulyx liturata Butler [larva and pupa]; Ampelophaga rubiginosa Ménétriés [larva and pupa]; Triptogon roseipennis Butler [larva]; Chaerocampa japonica Boisduval Llarva and pupa]; Polyptychus dentatus Cramer

[larva]; Pseudosphinx cyrtolophia Butler

[larva and pupa]; Pergesa mongoliana Butler

[larva and pupa]; Protoparce orientalis butler

[larva and pupa]; Diludia vates Butler [larva

and pupa]; Nephele hespera Fabricius [larva and pupaj

description and notes: chromolithograph; printed by Mintern Bros.; plate signed A.G. Butler Chromo-1ith. 1875

article: Butler, Arthur Gardiner. "Revision of the heterocerous Lepidoptera of the family

Sphingidae." y:511-644. 
CALMAN, Willian Thomas (1871-1952)

Volume 18 (1907-1911)

Plate 1

subject: Bodotria sublevis [female]; Bodotria similis [female and male]; Bodotria siamensis [female and male]; Bodotria parva [female] description and notes: lithograph; plate signed W.T. Calman del., Huth sc. et imp.

article: Calman, W.T. "On new or rare Crustacea of the order Cumacea from the collection of the Copenhagen Museum. Part I. The families Bodotriidae, Vauntompsoniidae, and Leuconidae." $18: 1-58$.

Plate 2

subject: Cyclaspis elegans [female and male] description and notes: lithograph; plate signed W.T. Calman del., Huth sc. et imp. article: Calman, W.'T. "On new or rare Crustacea of the order Cumacea from the collection of the Copenhagen Museum. Part I. The families Bodotriidae, Vauntompsoniidae, and Leuconidae." $18: 1-58$.

Plate 3

subject: Cyclaspis similis [female]; Cyclaspis biplicata [female and male]; Cyclaspis triplicata [female and male]

description and notes: lithograph; plate signed W.T. Calman del., Huth sc. et imp. article: Calman, W.T. "On new or rare Crustacea of the order Cumacea from the collection of the Copenhagen Museum. Part I. The families Bodotrildae, Vauntompsoniidae, and Leuconidae." $18: 1-58$. 
Plate 4

subject: Cyclaspis cingulata [female]; Cyclaspis uniplicata [female]

description and notes: lithograph; plate signed W.T. Calman del., Huth sc. et imp.

article: Calman, W.T. "On new or rare Crustacea of the order Cumacea from the collection of the Copenhagen Museum. Fart I. The families Bodotriidae, Vauntompsoniidae, and Leuconidae." $18: 1-58$.

Plate 5

subject: Cyclaspis longipes [female and male];

Cyclaspis levis [female]; Cyclaspis

unicornis [female]; Cyclaspis thomsoni

[female and male]

description and notes: lithograph; plate signed

w.T. Calman del., Huth sc. et imp.

article: Calman, W.T. "On new or rare Crustacea of

the order Cunacea from the collection of the

Copenhagen Museum. Part 1. The families

Bodotriidae, Vauntompsoniidae, and Leuconidae." $18: 1-58$.

Plate 6

subject: Eocuma longicornis [male]; Eocuma lata

[female]; Eocuma stellifera [female]; Eocuma producta [female]

description and notes: lithograph; plate signed W.T. Calman del., Huth sc. et imp.

article: Calman, W.T. "On new or rare Crustacea of the order Cumacea from the collection of the Copenhagen Museum. Part I. The families Bodotriidae, Vauntompsoniidae, and Leuconidae." $18: 1-58$.

Plate 7

subject: Zygosiphon mortenseni [female and male]; Vauntompsonia arabica [male]

description and notes: lithograph; plate signed W.T. Calman del., Huth sc. et imp.

article: Calman, W.T. "On new or rare Crustacea of the order Cumacea from the collection of the Copenhagen Museum. Part I. The families Bodotriidae, Vauntompsoniidae, and Leuconidae." 18:1-58. 
Plate 8

subject: Leucon(?) heterostylis [female];

Eudorellopsis resimus [female]; Heteroleucon akaroënsis [female and male]

description and notes: lithograph; plate signed W.T. Calman del., Huth sc. et imp.

article: Calman, W.T. "On new or rare Crustacea of the order Cumacea from the collection of the Copenhagen Museum. Fart I. The families Bodotriidae, Vauntompsoniidae, and Leucoridat." $18: 1-58$.

Plate 9

subject: Paraleucon suteri [female ana male];

Hemileucon uniplicatus [female and male];

Hemileucon comes [female and male]

description and notes: lithograph; plate signed

W.T. Calman del., Huth sc. et imp.

article: Calman, W.T. "On new or rare Crustacea of the order Cumacea from the collection of the Copenhagen Museum. Part I. The families Bodotriidae, Vauntompsoniidae, and Leuconidae." $18: 1-58$.

Plate 32

subject: Cumella forficula [female and malej; Cumella clavicauda [male]; Cumella leptopus [male]; Cumella hispida [female]; Cumella serrata [female and male]; Cumella laevis [female]

description and notes: lithograph; plate signed W.T. Calman del., Huth sc. et imp.

article: Calman, W.T. "On new or rare Crustacea of the order Cumacea from the collection of the Copenhagen Museum. Fart II. The fanilies Nannastacidae and Diastylidae." 18:341-398.

Plate 33

subject: Nannastacus lepturus [male];

Nannastacus zimmeri [female and male];

Nannastacus gibbosus [female]; Nannastacus reptans [female]

description and notes: chromolithograph; plate signed W.T. Calman del., Huth sc. et imp. article: Calman, W.T. "On new or rare Crustacea of the order Cumacea from the collection of the Copenhagen Museum. Part II. The families Nannastacidae and Diastylidae." 18:341-398. 
Plate 34

subject: Nannastacus minor [female]; Nannastacus tardus [female]; Nannastacus agnatus [female]; Schizotrema depressum [femalej; Schizotrema bifrons [female]; Schizotrema sordidum [female]; Campylaspis platyuropus [female]

description and notes: chromolithograph; plate signed W.T. Calman del., Huth sc. et imp.

article: Calman, W.T. "On new or rare Crustacea of the order Cumacea from the collection of the Copenhagen Museum. Part II. The families Nannastacidae and Diastylidae." 18:341-398.

Plate 35

subject: Campylaspis orientalis [female];

Gynodiastylis carinata [female and male];

Gynodiastylis laevis [female]

description and notes: chromolithograph; plate

signed W.T. Calman del., Huth sc. et imp.

article: Calman, W.T. "On new or rare Crustacea of the order Cumacea from the collection of the Copenhagen Museum. Part II. The families

Nannastacidae and. Liastylidae." 18:341-398.

Plate 36

subject: Gynodiastylis costata [female and male];

Gynodiastylis bicristata [female and male];

Colurostylis pseudocuma [female and male]

description and notes: lithograph; plate signed

W.T. Calman del., Huth sc. et imp.

article: Calman, W.T. "On new or rare Crustacea of the order Cumacea from the collection of the Copenhagen Museum. Part II. The families

Nannastacidae and Diastylidae." 18:341-396.

Plate 37

subject: Diastylopsis elongata [female and male];

Diastylopsis crassior [female]; Diastylis

koreana [female]; Diastylis fistularis [male?]

description and notes: lithograph; plate signed

W.T. Calman del., Huth sc. et imp.

article: Calman, W.T. "On new or rare Crustacea of the order Cumacea from the collection of the Copenhagen Museum. Part II. The families

Nannastacidae and Diastylidae." 18:341-398. 


\section{CANTOR, Theodore Edwara (1804-1879)}

\section{Volume 2 (1841)}

Plate 56

subject: Hydrophis gracilis, Schlegel

description and notes: hand-colored lithograph; plate signed 1. Cantor del., G. Scharf lithog. article: Cantor, Theodore. "Observations upon pelagic serpents." 2:303-313.

Plate 57

subject: Hydrophis schistosa, Schlegel

description and notes: engraving; plate signed $T$. Cantor delt., Swaine sc.; shows anatomical details

article: Cantor, Theodore. "Observations upon pelagic serpents." 2:303-313. 
Volume 4 (1862)

Plate 37

subject: Myrmecophaga jubata

description and notes: lithograph; printed by Day \& Son; plate signed E.V. Carter del., J. Erxleben, lith.; double-page folded plate

article: Owen, [Professor]. "On the anatomy of the great anteater (Myrmecophaga jubata, Linn.)." 4:117-140.

Plate 38

subject: Myrmecophaga jubata

description and notes: lithograph; printed by Day \& Son; plate signed E.V. Carter del., J. Erxleben, lith.; double-page folded plate; shows muscles of the tongue

article: Owen, [Professor]. "On the anatomy of the great anteater (Myrmecophaga jubata, Linn.)." 4:117-140.

Plate 39

subject: Myrmecophaga jubata

description and notes: lithograph; printed by Day \& Son; plate signed E.V. Carter del., J. Erxleben, lith.; double-page folded plate; shows anatomy of the head

article: Cwen, [Frofessor]. "On the anatomy of the great anteater (Myrmecophaga jubata, Linn.)." 4: $117-140$. 
CARTEK, H.V.

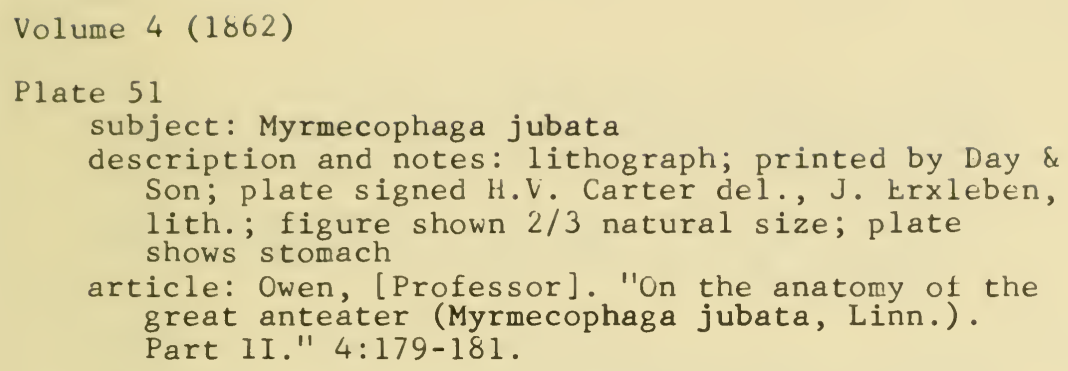


Volume $2(1841)$

\section{Plate 49}

subject: Apteryx australis

description and notes: engraving; plate signed $W$. Clift delt., Is. Basire sc.; shows anatomical details

article: Owen, [Richard]. "On the anatomy of the southern Apteryx (Apteryx australis, Shaw)." 2:257-301.

\section{Plate 51}

subject: Apteryx australis

description and notes: engraving; plate signed $W$. Clift delt., Is. Basire sc.; shows anatomical details

article: Owen, [Richard]. "On the anatomy of the southern Apteryx (Apteryx australis, Shaw)." $2: 257-301$.

Plate 52

subject: Apteryx australis

description and notes: engraving; plate signed $W$. Clift delt., Is. Basire sc.; shows anatomical details

article: Owen, [Richard]. "On the anatomy of the southern Apteryx (Apteryx australis, Shaw)." $2: 257-301$. 
CURTIS, Charles M.

Volume 2 (1841)

Plate 7

subject: Pteropus whitei

description and notes: engraving; plate signed C.

Curtis del., Weddell sc.; plate shows details of hairs

article: Bennett, E.T. "On a remarkable species of pteropine bat." 2:31-38.

Plate 38

subject: Echiodon drummondii

description and notes: engraving; plate signed

Chas. M. Curtis delt., J. Swaine sc.

article: Thompson, William. "On a new sub-genus of

fishes, allied to Ophidium." 2:207-212.

Plate 58

subject: Galeopithecus temminckii; Galeopithecus philippinensis

description and notes: engraving; plate signed C.M.

Curtis \& G.R. Waterhouse delt., J. Swaine Sc.;

gives views of skulls

article: Waterhouse, G.R. "On the genus

Galeopithecus." $2: 335-342$.

Volume 3 (1849)

Plate 4

subject: Serranus rasor; Nemadactylus concinnus

description and notes: hand-colored engraving;

plate signed Chas. M. Curtis delt., J. Swaine sc. article: Richardson, John. "Description of

Australian fish." 3:69-131.

Plate 5

subject: Trigla vanessa; Trigla polyommata description and notes: engraving; plate signed C.M. Curtis del., Js. Basire sc.

article: Richardson, John. "Description of

Australian fish.' 3:69-131. 
Plate 6

subject: Latris hecateia; Clinus despicillatus

description and notes: hand-colored engraving; plate signed C.M. Curtis del., J. Basire SC. article: Richardson, John. "Description of Australian fish." 3:69-131.

Plate 8

subject: Lepidolepris australis, Rich.

description and notes: engraving; plate signed C.M. Curtis delt., J. Swaine sc.; figure shown $1 / 2$ natural size

article: Kichardson, John. "(Fart 2.) Description of Australian fish." 3:133-185. 
CURTIS, John (1791-1862)

Volume 1 (1835)

Plate 40

subject: Ancistrosoma klugii; Cecidoses eremita description and notes: hand-colored engraving; plate signed J. Curtis, pinx. et direx. article: Curtis, John. "Characters and description of a new genus of the family Melolonthidae." $1: 307-310$. 
DeWILDE, G.K.

Volume $8(1874)$

Plate 41: "Deep Sea Corals"

subject: Sphenotrochus intermedius;

Sabinotrochus apertus; Desmophyllum crista-galli

description and notes: lithograph; printed by M. \& $\mathrm{N}$. Hanhart

article: Duncan, Y. Martin. "A description of the Madreporaria dredged up during the expeditions of H.M.S. 'Porcupine' in 1869 and 1870." $8: 303-344$.

Plate 44: "Deep Sea Corals"

subject: Amphihelia ramea; Caryophillia sequenzae; Lophohelia prolifera

description and notes: lithograph; printed by M. \& $\mathrm{N}$. Hanhart

article: Duncan, P. Martin. "A description of the Madreporaria dredged up during the expeditions of H.M.S. 'Porcupine' in 1869 and 1870." $8: 303-344$.

Plate 47: "Deep Sea Corals"

subject: Guynia annulata; Rhizotrochus affinis description and notes: lithograph; printed by M. \& N. Hanhart

article: Duncan, P. Martin. "A description of the Madreporaria dredged up during the expeditions of H.M.S. 'Porcupine' in 1865 and $1870 . "$

$8: 303-344$. 
Plate 48: "Deep Sea Corals"

subject: Bathycyathus atlanticus; Caryophyllia cyathus var. alpha; Caryophyllia clavus var. exserta; Caryophyliia clavus var. borealis; Caryophyllia clavus var. elongata; Caryophyllia clavus var. smithii; Caryophyllia clavus var. epithecata

description and notes: lithograph; printed by M. \& $\mathrm{N}$. Hanhart

article: Duncan, P. Martin. "A description of the Madreporaria dredged up during the expeditions of H.M.S. 'Porcupine' in 1869 and $1870 . "$

$8: 303-344$. 
DICKES, William (1815-1892)

Volume 2 (1841)

Plate 27

subject: Myrmecobius fasciatus

description and notes: hand-colored lithograph;

printed by Hullmandel; plate signed Lithographed from Nature by $W$. Dickes

article: Waterhouse, George R. "Description of a new genus of mammiferous animals from Australia, belonging probably to the order Marsupialia." $2: 149-154$.

Plate 46

subject: Echinops telfairi

description and notes: hand-colored lithograph

article: Martin, W.C.L. "On a new genus of

insectivorous Mammalia." 2:249-256. 
DINKEL, Joseph [fl. 1833-1806s]

\section{Volume $3(1849)$}

\section{Plate 56}

subject: Porphyrio; Notornis

description and notes: lithograph; printed by Day \& Son; plate signed J. Dinkel del. on Zinc by $J$. Erxleben; figures shown natural size

article: Cwen, [Professor]. "On Dinornis (Fart III.): containing a description of the skull and beak of that genus, and of the same characteristic parts of Palapteryx, and of two other genera of birds, Notornis and Nestor; forming part of an extensive series of ornithic remains discovered by Mr. Walter Mantell at Waingongoro, North Island of New Zealand." $3: 345-398$.

\section{Volume $4(1862)$}

\section{Plate 43}

subject: Dinornis elephantopus

description and notes: lithograph; printed by $W$. Wing; folded plate

article: Owen, [Protessor]. "On Dinornis (Part

VII.): containing a description of the bones of the leg and foot of Dinornis elephantopus, Owen." $4: 149-157$.

\section{Volume 6 (1869)}

\section{Plate 88}

subject: Dinornis robustus

description and notes: lithograph; printed by M. \& N. Hanhart; plate signed Dinkel, delt. on Stone by J. Erxleben

article: Owen, [Professor]. "On Dinornis (Part XI): containing a description of the integument of the sole, and tendons of a toe, of the foot of Dinornis robustus, Ow." 6:495-496. 


\section{Plate 89}

subject: Dinornis maximus

description and notes: lithograph; printed by $M$. \& N. Hanhart; plate signed Dinkel del. \& 1ith.; five-page folded plate

article: Owen, [Professor]. "On Dinornis (Fart XII.): containing a description of the femur, tibia, and metatarsus of Dinornis maximus, Owen." 6:497-500.

\section{Plate 90}

subject: Dinornis maximus

description and notes: lithograph; printed by M. \& N. Hanhart; plate signed Dinkel del. et lith.; five-page folded plate

article: Owen, [Professor]. "On Dinornis (Part XII.): containing a description of the femur, tibia, and metatarsus of Dinornis maximus, Owen." 6:497-500.

Volume $10(1879)$

Plate 1

subject: Hyena crocuta

description and notes: lithograph; printed by $W$. West; plate signed Dinkel del. et lith.

article: Busk, George. "On the ancient or

Quaternary fauna of Gibraltar, as exemplified in the mammalian remains of the ossiferous breccia." 10:53-136.

Plate 2

subject: Hyena crocuta

description and notes: lithograph; printed by $W$. West; plate signed Dinkel del. et lith. article: Busk, George. "On the ancient or Quaternary fauna of Gibraltar, as exemplified in the mammalian remains of the ossiferous breccia." 10:53-136.

Plate 3: "Felidae, Canis, Meles see B., E.M.

Plate 4

subject: Ursus arctos

description and notes: lithograph; printed by W.

West; plate signed Dinkel del. et 1 ith.

article: Busk, George. "On the ancient or

Quaternary fauna of Gibraltar, as exemplified in the mammalian remains of the ossiferous breccia." 10:53-136. 
Plate 6

subject: Ursus arctos

description and notes: lithograph; printed by $W$.

west; plate signed Dinkel del. et lith.

article: Busk, George. "On the ancient or

Quaternary fauna of Gibraltar, as exemplified in

the mammalian remains of the ossiferous

breccia." 10:53-136.

Plate 20

subject: Cervus elephus var. barbarus?; Ibex

description and notes: lithograph; printed by $W$.

West; plate signed Linkel del. et lith.

article: Busk, George. "On the ancient or

Quaternary fauna of Gibraltar, as exemplified in the mammalian remains of the ossiferous breccia." 10:53-136.

Plate 22

subject: Ibex

description and notes: lithograph; printed by $W$.

West; plate signed Dinkel del. et lith.

article: Busk, George. "On the ancient or

Quaternary fauna of Gibraltar, as exemplified in

the mammalian remains of the ossiferous

breccia." 10:53-136. 
Plate 27: "Oriental Hesperiidae"

subject: Parnara robusta; Parnara austeni Moore; Parnara kumara Moore; Parnara cahira Moore; Parnara conjuncta H.-S.; Hasora chromus $\mathrm{Cr}$. ; Hasora inermis; Bibasis uniformis; Bibasis sambavana

description and notes: lithograph; printed by West, Newman; plate signed J. Edwards ad nat. del. article: Elwes, H.J. and James Edwards. "A revision of the oriental Hesperiidae." 14:161-324. 


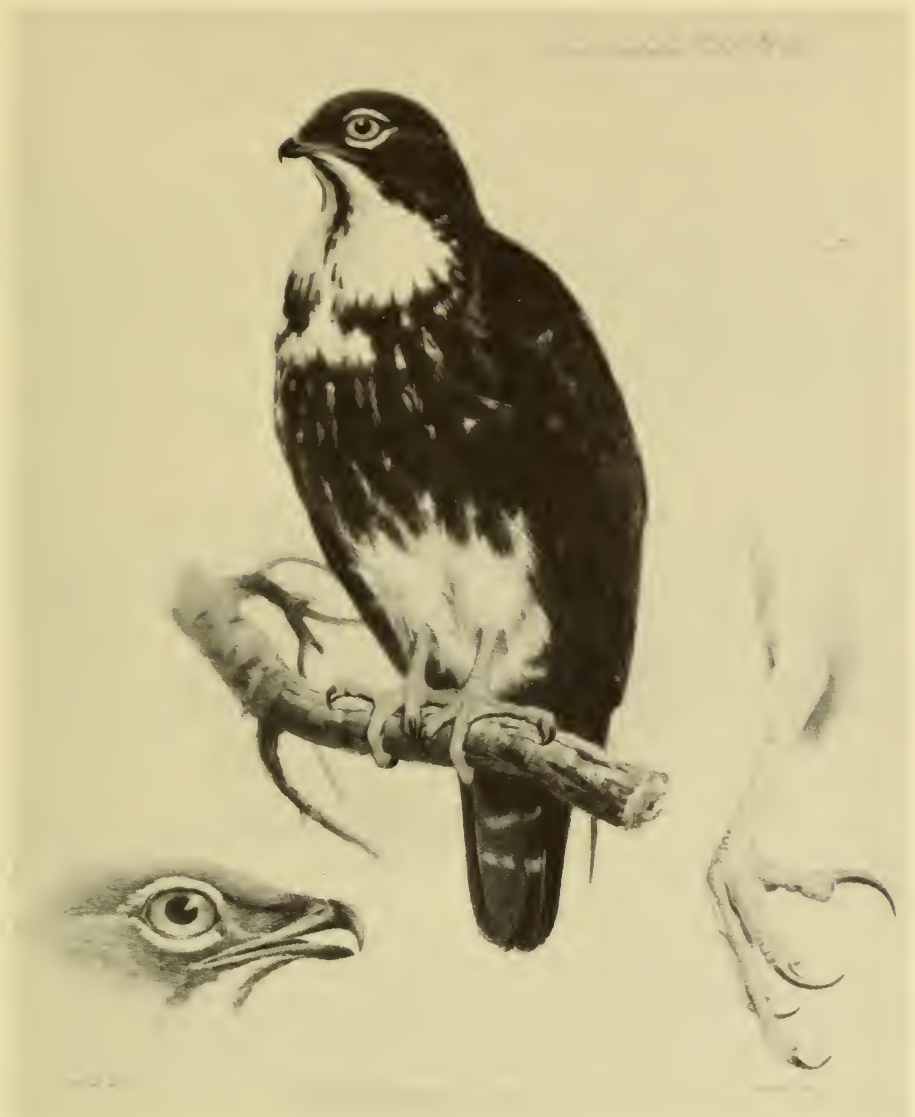

Macheirhamphus alcinus

(Wolf, 6: Plate 29)

AMNH Library Collections 

ERYLEBEN, James [f $1.1830-188 \mathrm{C}]$

\section{Volume 3 (1849)}

Plate 18

subject: Dinornis; Apteryx

description and notes: lithograph; printed by Day \& Haghe; plate signed J. Erxleben, Zinc

article: Owen, [Professor]. "On Dinornis, an extinct genus of tridactyle struthious birds, with descriptions of portions of the skeleton of five species which formerly existed in New Zealand." 3:235-275.

Plate 18 a

subject: Dinornis; Struthio; Apteryx

description and notes: lithograph; printed by Day \& Haghe; plate signed J. Erxleben, Zinc

article: Owen, [Professor]. "On Dinornis, an extinct genus of tridactyle struthious birds, with descriptions of portions of the skeleton of five species which formerly existed in New Zealand." 3:235-275.

Plate 19

subject: Dinornis; Struthio

description and notes: lithograph; printed by Day \& Haghe; plate signed J. Erxleben, Zinc; figures shown $1 / 3$ natural size

article: Owen, [Professor]. "On Dinornis, an extinct genus of tridactyle struthious birds, with descriptions of portions of the skeleton of five species which formerly existed in New Zealand." 3:235-275.

Plate 20

subject: Dinornis

description and notes: lithograph; printed by Day \& Haghe; plate signed J. Erxleben, Zinc; figures shown $1 / 3$ natural size

article: Owen, [Professor]. "On Dinornis, an extinct genus of tridactyle struthious birds, with descriptions of portions of the skeleton of five species which formerly existed in New Zealand." 3:235-275. 


\section{Plate 28}

subject: Struthio; Dinornis

description and notes: lithograph; printed by Day \& Haghe; plate signed J. Erxleben,, Zinc; figures shown $1 / 2$ natural size

article: Cwen, [Professor]. "On Dinornis, an extinct genus of tridactyle struthious birds, with descriptions of portions of the skeleton of five species which formerly existed in New Zealand." $3: 235-275$.

Plate 29

subject: Dinornis; Struthio; Apteryx

description and notes: lithograph; printed by Day \& Haghe; plate signed J. Erxleben, Zinc; figures shown natural or $1 / 2$ natural size

article: Owen, [Professor]. "On Dinornis, an extinct genus of tridactyle struthious birds, with descriptions of portions of the skeleton of five species which formerly existed in New Zealand." $3: 235-275$.

Plate 30

subject: Dinornis didiformis; Dinornis struthoides; Dinornis ingens; Dinornis giganteus; Casuarius galeatus

description and notes: lithograph; printed by Day \& Haghe; plate signed J. Erxleben, Zinc; shows relative size of legs for each species

article: Owen, [Professor]. "On Dinornis, an extinct genus of tridactyle struthious birds, with descriptions of portions of the skeleton of five species which formerly existed in New Zealand." 3:235-275.

Plate 38

subject: Dinornis struthioides; Didus ineptus

description and notes: lithograph; printed by Day \& Haghe; plate signed J. Erxleban from nat. on Zinc article: Owen, [Professor]. "Observations on the dodo (Didus ineptus, Linn.); an appendix to the foregoing memoir on the Dinornis." $3: 331-338$.

Plate 39

subject: Dromaius; Dinornis dromioides;

Dinornis gigas; Struthio; Apteryx

description and notes: lithograph; printed by Day \& Haghe; plate signed J. Erxleben del.

article: Owen, [Professor]. "Observations on the dodo (Didus ineptus, Linn.); an appendix to the foregoing memoir on the Dinornis." $3: 331-338$. 
Plate 40: "Cervical vertebrae"

subject: Dinornis ingens; Dinornis giganteus

description and notes: lithograph; printed by Day \& Haghe; plate signed J. Erxleben, Zinc.; figures shown natural size

article: Owen, [Professor]. "Observations on the dodo (Didus ineptus, Linn.); an appendix to the foregoing memoir on the Dinornis." $3: 331-338$.

Plate 42: "Dorsal vertebrae"

subject: Dinornis crassus (?); Dinornis ingens

description and notes: lithograph; printed by Day \& Haghe; plate signed J. Erxleben, Zinc.; figures shown natural size

article: Owen, [Professor]. "Observations on the dodo (Didus ineptus, Linn.); an appendix to the foregoing memoir on the Dinornis." $3: 331-338$.

Plate 43: "Sternum"

subject: Dinornis; Struthio; Rhea;

Casuarius; Dromaius; Apteryx

description and notes: lithograph; printed by Day \& Haghe; plate signed J. Erxleben, Zinc.; figures shown natural or $1 / 2$ natural size

article: Owen, [Professor]. "Observations on the dodo (Didus ineptus, Linn.); an appendix to the foregoing memoir on the Dinornis." $3: 331-338$.

Plate 44

subject: Dinornis gigantus

description and notes: lithograph; printed by Day \& Haghe; plate signed J. Erxleben, Zinc.; figures shown natural size

article: Owen, [Professor]. "Observations on the dodo (Didus ineptus, Linn.); an appendix to the foregoing memoir on the Dinornis." $3: 331-338$.

Plate 45

subject: Dinornis gigas; Struthio; Dromaius; Argala

description and notes: lithograph; printed by Day \& Haghe; plate signed J. Erxleben del.

article: Owen, [Professor]. "Observations on the dodo (Didus ineptus, Linn.); an appendix to the foregoing memoir on the Dinornis." $3: 331-338$. 
Plate 46

subject: Dinornis casuarinus

description and notes: lithograph; printed by Day \& Haghe; plate signed J. Erxleben, Zinc.; figures shown natural size

article: Owen, [Professor]. "Observations on the dodo (Didus ineptus, Linn.); an appendix to the foregoing memoir on the Dinornis." $3: 331-338$.

Plate 47: "Tibia"

subject: Palapteryx dromioides; Dinornis casuarinus; Dinornis curtus

description and notes: 1ithograph; printed by Day \& Haghe; plate signed J. Erxleben, Zinc.; figures shown natural size; double-page folded plate

article: Owen, [Professor]. "Observations on the dodo (Didus ineptus, Linn.); an appendix to the foregoing memoir on the Dinornis." $3: 331-338$.

Plate 48: "Tarso - metatarsus"

subject: Dinornis ingens; Dinornis dromioides;

Dinornis casuarinus; Dinornis crassus;

Dinornis curtus

description and notes: lithograph; printed by Day \& Haghe; plate signed J. Erxleben, Zinc.; figures shown natural size; double-page folded plate

article: Owen, [Professor]. "Observations on the dodo (Didus ineptus, Linn.); an appendix to the foregoing memoir on the Dinornis." $3: 331-338$.

Plate 49

subject: Didus; Haliaeetus; Apteryx

description and notes: lithograph; printed by Day \& Haghe; plate signed J. Erxleben, Zinc.; figures shown natural size

article: Owen, [Professor]. "Observations on the dodo (Didus ineptus, Linn.); an appendix to the foregoing memoir on the Dinornis." $3: 331-338$.

Plate 50

subject: Didus; Haliaeetus; Apteryx

description and notes: lithograph; printed by Day \& Haghe; plate signed J. Erxleben, Zinc.; figures shown natural size

article: Owen, [Professor]. "Observations on the dodo (Didus ineptus, Linn.); an appendix to the foregoing memoir on the Dinornis." $3: 331-338$. 
Plate 52

subject: Dinornis; Otis

description and notes: lithograph; printed by Day \&

Son; plate signed From Nature on Zinc by $\mathrm{J}$.

Erxleben; figures shown natural size

article: Owen, [Professor]. "On Dinornis (Part

III.): containing a description of the skull and

beak of that genus, and of the same

characteristic parts of Palapteryx, and of two

other genera of birds, Notornis and Nestor;

forming part of an extensive series of ornithic

remains discovered by $\mathrm{Mr}$. Walter Mantell at

Waingongoro, North Island of New Zealand."

$3: 345-378$.

Plate 53

subject: Dinornis; Struthio; Palapteryx;

Nestor

description and notes: lithograph; printed by Day $\&$

Son; plate signed From Nature on Zinc by J.

Erxleben; figures shown natural size

article: Owen, [Professor]. "On Dinornis (Part

III.): containing a description of the skull and beak of that genus, and of the same

characteristic parts of Palapteryx, and of two

other genera of birds, Notornis and Nestor;

forming part of an extensive series of ornithic

remains discovered by Mr. Walter Mantell at

Waingongoro, North Island of New Zealand." $3: 345-398$.

Plate 54

subject: Palapteryx

description and notes: 1ithograph; printed by Day \&

Son; plate signed From Nature on Zinc by $J$.

Erxleben; figures shown natural size

article: Owen, [Professor]. "On Dinornis (Part

III.): containing a description of the skull and beak of that genus, and of the same

characteristic parts of Palapteryx, and of two

other genera of birds, Notornis and Nestor;

forming part of an extensive series of ornithic

remains discovered by $\mathrm{Mr}$. Walter Mantell at

Waingongoro, North Island of New Zealand."

$3: 345-378$. 
Plate 55

subject: Palapteryx

description and notes: lithograph; printed by Day \& Son; plate signed From Nature on Zinc by $\mathrm{J}$.

Erxleben; figures shown natural size

article: Owen, [Professor]. "On Dinornis (Part

III.): containing a description of the skull and beak of that genus, and of the same

characteristic parts of Palapteryx, and of two other genera of birds, Notornis and Nestor; forming part of an extensive series of ornithic remains discovered by Mr. Walter Mantell at Waingongoro, North Island of New Zealand." $3: 345-378$.

Plate 58

subject: Troglodytes niger [male]

description and notes: Iithograph; printed by Day \& Son; plate signed From Nature on Stone by $\mathrm{J}$.

Erxleban; shows profile of skull; figure shown natural size

article: Owen, [Professor]. "Osteological

contributions to the natural history of the chimpanzees (Troglodytes geoffroy), including the description of the skull of a large species (Troglodytes gorilla, Savage) discovered by Thomas S. Savage, M.D., in the Gaboon country, West Africa." 3:381-422.

Plate 59

subject: Troglodytes niger [male]

description and notes: Iithograph; printed by Day \& Son; plate signed From Nature on Stone by $\mathrm{J}$. Erxleban; shows front view of skull; figure shown natural size

article: Owen, [Professor]. "Osteological contributions to the natural history of the chimpanzees (Troglodytes geoffroy), including the description of the skull of a large species (Troglodytes gorilla, Savage) discovered by Thomas S. Savage, M.D., in the Gaboon country, West Africa." 3:381-422. 
Plate 60

subject: Troglodytes niger [male]

description and notes: Iithograph; printed by Day \&

Son; plate signed From Nature on Stone by J.

Erxleban; shows base view of skull; figure shown natural size

article: Owen, [Professor]. "Osteological

contributions to the natural history of the

chimpanzees (Troglodytes geoffroy), including

the description of the skull of a large species

(Troglodytes gorilla, Savage) discovered by

Thomas S. Savage, M.D., in the Gaboon country, West Africa." $3: 381-422$.

Plate 61

subject: Troglodytes gorilla [male]

description and notes: 1ithograph; printed by Day \& Son; plate signed From Nature on Zinc by J.

Erxleban; shows profile of skull; figure shown natural size

article: Owen, [Professor」. "Osteological

contributions to the natural history of the

chimpanzees (Troglodytes geoffroy), incluaing

the description of the skull of a large species

(Troglodytes gorilla, Savage) discovered by

Thomas S. Savage, M.D., in the Gaboon country, West Africa." $3: 381-422$.

Plate 62

subject: Troglodytes gorilla [male]

description and notes: 1ithograph; printed by Day \& Son; plate signed From Nature on Stone by $\mathrm{J}$. Erxleban; shows front view of skull; figure shown natural size

article: Owen, [Professor]. "Osteological contributions to the natural history of the chimpanzees (Troglodytes geoffroy), including the description of the skull of a large species (Troglodytes gorilla, Savage) discovered by Thomas S. Savage, M.D., in the Gaboon country, West Africa." 3:381-422.

Plate 63

subject: Troglodytes gorilla [malej

description and notes: lithograph; printed by Day \& Son; plate signed From Nature on Zinc by $\mathrm{J}$.

Erxleban; shows base view of skull; figure shown natural size

article: Owen, [Professor]. "Osteological

contributions to the natural history of the chimpanzees (Troglodytes geoffroy), including the description of the skull of a large species (Troglodytes gorilla, Savage) discovered by Thomas S. Savage, M.D., in the Gaboon country, West Africa." $3: 381-422$. 
Volume 4 (1862)

Plate 1

subject: Palapteryx robustus

description and notes: lithograph; printed by Day \& Son; plate signed From Nature on Stone by $\mathrm{J}$. Erxleben; folded plate

article: Owen, [Professor]. "On Dinornis (Part IV.): containing the restoration of the feet of that genus and of Palapteryx, with a description of the sternum in Palapteryx and Aptornis." 4:1-20.

Plate 2

subject: Palapteryx dromioides; Notornis mantel1i; Apteryx australis

description and notes: lithograph; printed by Lay \& Son; folded plate

article: Owen, [Professor]. "On Dinornis (Part

IV.): containing the restoration of the feet of that genus and of Palapteryx, with a description of the sternum in Palapteryx and Aptornis." 4:1-20.

Plate 3

subject: Dinornis rheides; Aptornis otidiformis

description and notes: lithograph; printed by Day \& Son; folded plate

article: Owen, [Professor]. "On Dinornis (Part

IV.): containing the restoration of the feet of that genus and of Palapteryx, with a description of the sternum in Palapteryx and Aptornis." 4:1-20.

Plate 4

subject: Palapteryx; Notornis mantelli

description and notes: lithograph; printed by Day \& Son; folded plate

article: Owen, [Professor]. "On Dinornis (Part

IV.) : containing the restoration of the feet of that genus and of Palapteryx, with a description of the sternum in Palapteryx and Aptornis." 4:1-20.

Plate 9

subject: Rhinoceros indicus

description and notes: lithograph; printed by Day \& Son; plate signed From Nature on Stone by J. Erxleben

article: Owen, [Professor]. "On the anatomy of the Indian rhinoceros (Rh. unicornis, L.).' $4: 31-58$. 
Plate 10

subject: Rhinoceros indicus

description and notes: lithograph; printed by Day \& Son; plate signed From Nature on Stone by J. Erxleben

article: Owen, [Professor]. "Cn the anatomy of the Indian rhinoceros (Rh. unicornis, L.).'

4:31-58.

Plate 11

subject: Rhinoceros indicus

description and notes: lithograph; plate signed From Nature on Stone by J. Erxleben; printer not given on plate

article: Owen, [Professor]. "Cn the anatomy of the Indian rhinoceros (Rh. unicornis, L.)."

4:31-58.

Plate 12

subject: Rhinoceros indicus

description and notes: lithograph; printed by Day \& Son; plate signed From Nature on Stone by $\mathrm{J}$.

Erxleben

article: Owen, [Professor]. "On the anatomy of the Indian rhinoceros (Rh. unicornis, L.).'

4:31-58.

Plate 13

subject: Rhinoceros indicus

description and notes: lithograph; printed by Day \& Son; plate signed From Nature on Stone by $\mathrm{J}$.

Erxleben

article: Owen, [Professor]. "On the anatomy of the

Indian rhinoceros (Rh. unicornis, L.)."

$4: 31-58$.

Plate 14

subject: Rhinoceros indicus

description and notes: lithograph; printed by Day \& Son; plate signed From Nat. on stone by $\mathrm{J}$.

Erxleben

article: Owen, [Professor]. "On the anatomy of the Indian rhinoceros (Rh. unicornis, L.).

4:31-58.

Plate 15

subject: Rhinoceros indicus

description and notes: lithograph; printed by Day \& Son; plate signed From Nat. on Stone by J.

Erxleben

article: Owen, [Professor]. "On the anatomy of the Indian rhinoceros (Rh. unicornis, L.)."

$4: 31-58$. 
Plate 16

subject: Rhinoceros indicus

description and notes: 1ithograph; printed by Day \& Son; plate signed From Nat. on Stone by J. Erxleben

article: Owen, [Professor]. "On the anatomy of the Indian rhinoceros (Rh. unicornis, L.)." 4:31-58.

Plate 17

subject: Rhinoceros indicus

description and notes: 1ithograph; printed by Day \& Son; plate signed From Nat. on Stone by J. Erxleben

article: Owen, [Professor]. "On the anatomy of the Indian rhinoceros (Rh. unicornis, L.)." 4:31-58.

Plate 18

subject: Rhinoceros indicus

description and notes: lithograph; printed by Day \& Son; plate signed From Nat. on Stone by J. Erxleben

article: Owen, [Professor]. "Cn the anatomy of the Indian rhinoceros (Rh. unicornis, L.)." 4:31-58.

Plate 19

subject: Rhinoceros indicus

description and notes: lithograph; printed by Day \& Son; plate signed From Nature on Stone by $\mathrm{J}$. Erxleben

article: Owen, [Professor]. "On the anatomy of the Indian rhinoceros (Rh. unicornis, L.)." $4: 31-58$.

Plate 20

subject: Rhinoceros indicus

description and notes: 1ithograph; printed by Day \& Son; plate signed From Nat. on Stone by $\mathrm{J}$.

Erxleben

article: Owen, [Professor]. "On the anatomy of the Indian rhinoceros (Rh. unicornis, L.)." 4:31-58.

Plate 21

subject: Rhinoceros indicus

description and notes: lithograph; printed by Day \& Son; plate signed From Nat. on Stone by $J$. Erxleben

article: Owen, [Professor]. "On the anatomy of the Indian rhinoceros (Rh. unicornis, L.).' 4:31-58. 
Plate 22

subject: Rhinoceros indicus

description and notes: lithograph; printed by Day \& Son; plate signed From Nat. on Stone by $\mathrm{J}$.

Erxleben

article: Owen, [Protessor]. "On the anatomy of the Indian rhinoceros (Kh. unicornis, L.).'

4:31-58.

Plate 23

subject: Dinornis ingens?

description and notes: lithograph; printed by Day \& Son; plate signed From Nat. on Stone by $\mathrm{J}$.

Erxleben

article: Owen, [Professor]. "On Dinornis (Part

V.): containing a description of the skull and

beak of a large species of Dinornis, of the cranium of an immature specimen of Dinornis giganteus (?), and of crania of species of Palapteryx." 4:59-68.

Plate 24

subject: Dinornis giganteus (pullus)?;

Palapteryx

description and notes: lithograph; printed by Day \& Son; plate signed From Nature on Stone by $\mathrm{J}$.

Erxleben

article: Owen, [Professor]. "On Dinornis (Part

V.): containing a description of the skull and

beak of a large species of Dinornis, of the cranium of an immature specimen of Dinornis giganteus (?), and of crania of species of Palapteryx." 4:59-68.

Plate 32: "Maxilla Inferior"

subject: Troglodytes gorilla; Homo sapiens;

Troglodytes niger

description and notes: lithograph; printed by Day \& Son; plate signed From Nature on Stone by J.

Erxleben

article: Owen, [Professor]. "Osteological

contributions to the natural history of the chimpanzees (Troglodytes) and orangs

(Pithecus). No. V. Comparison of the lower jaws and vertebral column varieties of the human race." $4: 89-115$. 
Plate 33: "Vertebrae cervicales"

subject: Troglodytes gorilla; Homo sapiens var. aethiopicus; Pithecus wurmbii; Pithecus satyrus

description and notes: lithograph; printed by Lay \& Son; plate signed From Nature on Stone by $\mathrm{J}$. Erxleben; two-page folded plate

article: Owen, [Professor]. "Osteological contributions to the natural history of the chimpanzees (Troglodytes) and orangs

(Pithecus). No. V. Comparison of the lower jaws and vertebral column varieties of the human race." 4:89-115.

Plate 34: "Vertebrae dorsales"

subject: Troglodytes gorilla; Homo sapiens var. aethiopicus

description and notes: lithograph; printed by Day \& Son; plate signed From Nature on Stone by $\mathrm{J}$.

Erxleben; two-page folded plate

article: Owen, [Professor]. "Osteological

contributions to the natural history of the chimpanzees (Troglodytes) and orangs

(Pithecus). No. V. Comparison of the lower jaws and vertebral column varieties of the human race." 4:89-115.

Plate 35: "Vertebrae lumbales"

subject: Troglodytes gorilla; Homo sapiens var. aethiopicus; Troglodytes niger

description and notes: lithograph; printed by Day \& Son; plate signed From Nature on Stone by $\mathrm{J}$. Erxleben; two-page folded plate

article: Owen, [Professor]. "Osteological

contributions to the natural history of the

chimpanzees (Troglodytes) and orangs

(Pithecus). No. V. Comparison of the lower

jaws and vertebral column varieties of the human race. " $4: 89-115$.

Plate 36: "Sacrum"

subject: Troglodytes gorilla; Troglodytes

niger; Homo sapiens

description and notes: lithograph; printed by Lay \& Son; plate signed From Nature on Stone by $\mathrm{J}$.

Erxleben; two-page folded plate; human examples are from an Australian and a European

article: Owen, [Professor]. "Osteological

contributions to the natural history of the chimpanzees (Troglodytes) and orangs

(Pithecus). No. V. Comparison of the lower jaws and vertebral column varieties of the human race." $4: 89-115$. 
Plate 41

subject: Linornis gracilis; Dinornis struthioides

description and notes: lithograph; printed by Day \& Son; plate signed from Nat. on Stone by $J$.

Erxleben; folded plate

article: Owen, [Professor]. "On Dinornis (Part

VI.): containing a description of the bones of the leg of Dinornis (Palapteryx) struthioides and of Dinornis gracilis, Owen." 4:141-147.

Plate 42

subject: Dinornis gracilis; Dinornis struthioides

description and notes: lithograph; printed by Day \& Son; plate signed From Nat. on Stone by $\mathrm{J}$.

Erxleben; folded plate

article: Owen, [Professor]. "On Dinornis (Part

VI.): containing a description of the bones of

the leg of Dinornis (Palapteryx) struthioides

and of Dinornis gracilis, Owen." 4:141-147.

Plate 44

subject: Dinornis elephantopus

description and notes: lithograph; printed by Lay \&

Son; plate signed From liature on Stone by $\mathrm{J}$.

Erxleben; folded plate

article: Owen, [Professor]. "Cn Dinornis (Yart

VII.): containing a description of the bones of

the leg and foot of Dinornis elephantopus,

Owen." $4: 149-157$.

Plate 45

subject: Dinornis elephantopus; Dinornis

crassus [juvenile]

description and notes: 1ithograph; printed by Day \& Son; plate signed From Nature on Stone by $\mathrm{J}$. Erxleben

article: Owen, [Professor]. "On Dinornis (Part

VII.): containing a description of the bones of

the leg and foot of Dinornis elephantopus, Owen." $4: 149-157$.

Plate 46

subject: Dinornis elephantopus

description and notes: lithograph; printed by Day \& Son; plate signed From a Photograph, on Stone by J. Erxleben; shows articulated skeleton

article: Owen, [Professor]. "On Dinornis (Part

VIII.): containing a description of the

skeleton of the Dinornis elephantopus, Owen." $4: 159-164$. 
Plate 47

subject: Dinornis elephantopus; Dinornis robustus

description and notes: lithograph; printed by Lay \& Son; plate signed From a Photograph, on Stone by J. Erxleben; shows an articulated skeleton of D. elephantopus and articulated legs of D. robustus; D. robustus incorrectly identified on plate as Dinornis giganteus

article: Owen, [Professor]. "Cn Dinornis (Part VIII.): containging a description of the skeleton of the Dinornis elephantopus, Owen." $4: 159-164$.

Plate 65

subject: Balaeniceps rex

description and notes: lithograph; printed by $M$. \& $N$. Hanhart; plate signed From rat. on Stone by J. Erxleben; figures shown natural size; double-page folded plate

article: Sclater, Thilip Lutley. "On the osteology of Balaeniceps rex (Gould)." 4:269-351.

Plate 66

subject: Balaeniceps rex

description and notes: lithograph; printed by $M$. \& N. Hanhart; plate signed From liat. on Stone by $\mathrm{J}$. Erxleben; figures shown $1 / 2$ natural and natural size; double-page folded plate

article: Sclater, Philip Lutley. "On the osteology of Balaeniceps rex (Gould)." 4:269-351.

Plate 67

subject: Balaeniceps rex

description and notes: lithograph; printed by $M$. \& N. Hanhart; plate signed From lvat. on Stone by

J. Erxleben; figures shown natural size

article: Sclater, Philip Lutley. "On the osteology

of Balaeniceps rex (Gould)." 4:269-351. 
Volume 5 (1866)

Plate 1: "Scapula"

subject: Troglodytes gorilla; Troglodytes niger; Homo

description and notes: lithograph; printed by Day \& Son; plate signed From Nature on Stone by J. Erxleben; tolded plate

article: Owen, [Professor]. "Osteological contributions to the natural history of the anthropoid apes. No. VII. Comparison of the bones of the limbs of the Troglodytes gorilla, Troglodytes niger, and of different varieties of the human race; and on the general characters of the skeleton of the gorilla." $5: 1-31$.

Plate 2: "Clavicula. Ossicula carpi" subject: Troglodytes gorilla; Troglodytes niger; Homo

description and notes: lithograph; printed by Lay \& Son; plate signed From Nature on Stone by $\mathrm{J}$. Erxieben

article: Owen, [Professor]. "Osteological contributions to the natural history of the anthropoid apes. No. VII. Comparison of the bones of the limbs of the Troglodytes gorilla, Troglodytes niger, and of different varieties of the human race; and on the general characters of the skeleton of the gorilla." 5:1-3l.

Plate 3: "Humerus"

subject: Troglodytes gorilla; Troglodytes niger; Homo

description and notes: 1ithograph; printed by Day \& Son; plate signed From Nature on Stone by J. Erxleben; folded plate; human bones shown are from an Australian and a European

article: Owen, [Professor]. "Osteological contributions to the natural history of the anthropoid apes. No. VII. Comparison of the bones of the limbs of the Troglodytes gorilla, Troglodytes niger, and of different varieties of the human race; and on the general characters of the skeleton of the gorilla." 5:1-31. 
Plate 4: "Radius"

subject: Troglodytes gorilla; Troglodytes niger; Homo

description and notes: lithograph; printed by Day \& Son; plate signed From Nature on Stone by $\mathrm{J}$. Erxleben; folded plate; human bones shown are from an Australian and a European

article: Owen, [Professor]. "Csteological contributions to the natural history of the anthropoid apes. No. VII. Comparison of the bones of the limbs of the Troglodytes gorilla, Troglodytes niger, and of different varieties of the human race; and on the general characters of the skeleton of the gorilla." 5:1-31.

Plate 5: "Ulna"

subject: Troglodytes gorilla; Troglodytes niger; Homo

description and notes: 1ithograph; printed by Day \& Son; plate signed From Nature on Stone by J. Erxleben; folded plate; human bones shown are from an Australian and a European

article: Owen, [Professor]. "Osteological contributions to the natural history of the anthropoid apes. No. VII. Comparison of the bones of the limbs of the Troglodytes gorilla, Troglodytes niger, and of different varieties of the human race; and on the general characters of the skeleton of the gorilla." $5: 1-31$.

Plate 6: "Asinnominatum"

subject: Troglodytes gorilla; Troglodytes niger; Homo var. ethiopicus

description and notes: lithograph; printed by Day \& Son; plate signed From Nature on Stone by $\mathrm{J}$. Erxleben; folded plate; human bone shown is from an adult, male Australian

article: Cwen, [Professor]. "Osteological contributions to the natural history of the anthropoid apes. No. VII. Comparison of the bones of the limbs of the Troglodytes gorilla, Troglodytes niger, and of different varieties of the human race; and on the general characters of the skeleton of the gorilla." 5:1-31. 
Plate 9: "Manubrium Sterni"

subject: Troglodytes gorilla; Troglodytes niger; Homo

description and notes: lithograph; printed by Lay \& Son; plate signed From Nature on Stone by $\mathrm{J}$.

Erxleben; human bones shown are from an

Australian and a European

article: Owen, [Professor]. "Osteological

contributions to the natural history of the anthropoid apes. No. VII. Comparison of the bones of the limbs of the Troglodytes gorilla, Troglodytes niger, and of different varieties of the human race; and on the general characters of the skeleton of the gorilla." 5:1-31.

Flate 19

subject: Chiromys madagascariensis Cuv. [male]

description and notes: lithograph; printed by M. \&

N. Hanhart; plate signed J. Erxleben del. et

lith.; figure shown natural size; folded plate

article: Owen, [Professor]. "On the aye-aye

(Chiromys, Cuvier; Chiromys

madagascariensis, Lesm.; Sciurus

madagascariensis, Gmel., Sonnerat; Lemur

psilodactylus, Schreber, Shaw)." 5:33-101.

Plate 20

subject: Chiromys madagascariensis Cuv. [male]

description and notes: lithograph; printed by $M . \&$

N. Hanhart; plate signed J. Erxleben del. et

lith.

article: Owen, [Professor]. "On the aye-aye

(Chiromys, Cuvier; Chiromys

madagascariensis, Desm.; Sciurus

madagascariensis, Gmel., Sonnerat; Lemur

psilodactylus, Schreber, Shaw)." 5:33-101.

Plate 21

subject: Chiromys madagascariensis Cuv.

description and notes: lithograph; printed by $M$. \&

N. Hanhart; plate signed J. Erxleben del. et

lith.; figure shown natural size

article: Owen, [Professor]. "On the aye-aye

(Chiromys, Cuvier; Chiromys

madagascariensis, Desm.; Sciurus

madagascariensis, Gmel., Sonnerat; Lemur

psilodactylus, Schreber, Shaw)." 5:33-101. 


\section{Plate 22}

subject: Chiromys madagascariensis Cuv.

description and notes: lithograph; printed by $\mathrm{M}$. \& $N$. Hanhart; plate signed J. Erxleben del. et 1ith.; figure shown natural size

article: Owen, [Professor]. "On the aye-aye (Chiromys, Cuvier; Chiromys madagascariensis, Desm.; Sciurus madagascariensis, Gmel., Sonnerat; Lemur psilodactylus, Schreber, Shaw)." 5:33-101.

Plate 23

subject: Chiromys madagascariensis Cuv.

description and notes: lithograph; printed by N.\& N. Hanhart; plate signed J. Erxleben del. et lith.

article: Owen, [Professor]. "On the aye-aye (Chiromys, Cuvier; Chiromys madagascariensis, Desm.; Sciurus madagascariensis, Gmel., Sonnerat; Lemur psilodactylus, Schreber, Shaw)." 5:33-101.

Plate 24

subject: Chiromys madagascariensis Cuv. [male] description and notes: lithograph; printed by $M$. \& N. Hanhart; plate signed J. Erxleben del. et lith.; figure shown natural size; folded plate article: Cwen, [Professor]. "On the aye-aye

(Chiromys, Cuvier; Chiromys madagascariensis, Desm.; Sciurus madagascariensis, Gmel., Sonnerat; Lemur psilodactylus, Schreber, Shaw)." 5:33-101.

Plate 25

subject: Chiromys madagascariensis Cuv.

description and notes: 1ithograph; printed by M. \& $\mathrm{N}$. Hanhart; plate signed J. Erxleben del. et lith.

article: Owen, [Professor]. "On the aye-aye

(Chiromys, Cuvier; Chiromys

madagascariensis, Desm.; Sciurus

madagascariensis, Gmel., Sonnerat; Lemur

psilodactylus, Schreber, Shaw)." 5:33-101.

Plate 26

subject: Chiromys madagascariensis Cuv. [male] description and notes: 1ithograph; printed by $M$. \&

N. Hanhart; plate signed J. Erxleben del. et

lith.; figure shown natural size

article: Owen, [Professor]. "On the aye-aye

(Chiromys, Cuvier; Chiromys

madagascariensis, Desm.; Sciurus

madagascariensis, Gmel., Sonnerat; Lemur psilodactylus, Schreber, Shaw)." 5:33-101. 
Plate 38

subject: Syrrhaptes paradoxus

description and notes: lithograph; printed by $M$. \&

N. Hanhart; plate signed From lat. on Stone by

J. Erxleben; figure shown natural size

article: Parker, W.K. "On the osteology of gallinaceous birds and tinamous." 5:145-241.

Plate 39

subject: Tinamus robustus

description and notes: lithograph; printed by $\wedge$. \&

N. Hanhart; plate signed From Nat. on Stone by

J. Erxleben; figure shown $4 / 5$ natural size

article: Parker, W.K. "On the osteology of

gallinaceous biràs and tinamous." 5:149-241.

Plate 40

subject: Tinamus robustus

description and notes: 1ithograph; printed by M. \&

N. Hanhart; plate signed From Nat. on Stone by

$\mathrm{J}$. Erxleben; figures shown natural size and $2 \mathrm{x}$ natural size

article: Parker, W.K. "On the osteology of gallinaceous birds and tinamous." 5:149-241.

Plate 41

subject: Tinamus robustus; Syrrhaptes

paradoxus; Perdix cinerea

description and notes: 1ithograph; printed by $M$. \&

N. Hanhart; plate signed From Nat. on Stone by

J. Erxleben; figures shown natural size

article: Parker, W.K. "On the osteology of

gallinaceous birds and tinamous." 5:149-241.

Plate 53

subject: Dinornis robustus

description and notes: lithograph; printed by Day \& Son; plate signed From Nature \& on Stone by $\mathrm{J}$. Erxleben

article: Owen, [Professor]. "On Dinornis (Part IX.): containing a description of the skull, atlas, and scapulocoracoid bone of the Donornis robustus, Owen." 5:337-358.

Plate 54

subject: Dinornis robustus

description and notes: lithograph; printed by Day \& Son; plate signed From liature \& on Stone by J. Erxleben

article: Cwen, [Professor]. "On Dinornis (Part

IX.): containing a description of the skull, atlas, and scapulocoracoid bone of the Donornis robustus, Owen." 5:337-358. 
Plate 55

subject: Dinornis robustus

description and notes: lithograph; printed by Day \& Son; plate signed From liature on Stone by $\mathrm{J}$. Erxleben

article: Owen, [Professor]. "On Dinornis (Fart

IX.): containing a description of the skul1, atlas, and scapulocoracoid bone of the Donornis robustus, Owen." $5: 337-358$.

Plate 56

subject: Dinornis robustus

description and notes: lithograph; printed by Day \& Son; plate signed From Nature \& on Stone by $\mathrm{J}$. Erxleben

article: Owen, [Professor]. "On Dinornis (Part IX.): containing a description of the skull, atlas, and scapulocoracoid bone of the Donornis robustus, Owen." 5:337-358.

Plate 63: "Cnemiornis"

subject: Cnemiornis calcitrans

description and notes: lithograph; printed by M. \& N. Hanhart; plate signed From Nat. on Stone by J. Erxleben

article: Cwen, [Professor]. "On Dinornis (Part X.) : containing a description of part of the skeleton of a flightless bird indicative of a new genus and species (Cnemiornis clacitrans, Cw.)." $5: 395-404$.

Plate 64: "Cnemiornis"

subject: Cnemiornis calcitrans

description and notes: lithograph; printed by $M$. \& N. Hanhart; plate signed From Nat. on Stone by J. Erxleben; folded plate

article: Owen, [Professor]. "On Dinornis (Part $\left.X_{.}\right)$: containing a description of part of the skeleton of a flightless bird indicative of a new genus and species (Cnemiornis clacitrans, Ow.)." $5: 395-404$.

Plate 65

subject: Cnemiornis calcitrans; Aptornis didiformis; Dinornis geranoïdes; Dinornis aeranoides

description and notes: Iithograph; printed by Day \& Son; plate signed From Nature on Stone by $\mathrm{J}$. Erxleben

article: Owen, [Professor]. "On Dinornis (Part $\left.x_{.}\right)$: containing a description of part of the skeleton of a flightless bird indicative of a new genus and species (Cnemiornis clacitrans, Ow.)." $5: 395-404$. 
Plate 66: "Cnemiornis"

subject: Cnemiornis calcitrans

description and notes: lithograph; printed by Day \&

Son; plate signed From Nature on Stone by $\mathrm{J}$.

Erxleben; folded plate

article: Owen, [Professor]. "On Dinornis (Yart $X$.$) : containing a description of part of the$ skeleton of a flightless bird indicative of a new genus and species (Cnemiornis clacitrans, Ow.)." $5: 395-404$.

Plate 67

subject: Cnemiornis calcitrans; Dinornis geranoïdes

description and notes: lithograph; printed by li. \& i. Hanhart; plate signed From Nat. on Stone by J. Erxleben

article: Owen, [Professor]. "On Dinornis (Part $X$.$) : containing a description of part of the$ skeleton of a flightless bird indicative of a new genus and species (Cnemiornis clacitrans, Ow.)." $5: 395-404$.

Volume 6 (1869)

Plate 4

subject: Delphinus gadamu

description and notes: lithograph; printed by M. \& N. Hanhart; plate signed From nat. on Stone by J. Erxleben; figures shown $1 / 2$ natural size; shows details of jaw

article: Owen, [Professor]. "Cn some Indian Cetacea collected by Walter Elliot, Esq." 6:17-47.

Plate 7

subject: Delphinus (Lagenorhynchus) fusiformis description and notes: lithograph; printed by M. \& N. Hanhart; plate signed J. Erxleben, lith ad nat.; shows details of jaw

article: Owen, [Professor]. "On some Indian Cetacea collected by Walter Elliot, Esq." 6:17-47.

Plate 8

subject: Delphinus pomeegra; Delphinus euphrosine

description and notes: lithograph; printed by M. \& N. Hanhart; plate signed J. Erxleben, lith ad nat.; shows details of jaws

article: Owen, [Professor]. "On some Indian Cetacea collected by Walter Elliot, Esq." 6:17-47. 
Plate 15

subject: Didunculus strigirostris, Jde.; Didus ineptus, L.

description and rotes: lithograph; printed by $N$. \& N. Hanhart; plate signed from nat. on Stone by

J. Erxleben; folio-size folded plate, India paper; shows articulated skeletons

article: Cwen, [Professor]. "Cn the osteology of the dodo (Didus ineptus, Linn.)." 6:49-85.

Plate 17

subject: Didus ineptus

description and notes: 1ithograph; printed by M. \& N. Hanhart; plate signed From nat. on Stone by J. Erxleben

article: Cwen, [Professor]. "On the osteology of the dodo (Didus ineptus, Linn.)." 6:49-85.

Plate 20

subject: Didus ineptus

description and notes: lithograph; printed by $M$. \& N. Hanhart; plate signed From nat. on Stone by J. Erxleben

article: Owen, [Professor]. "On the osteology of the dodo (Didus ineptus, Linn.)." 6:49-85.

Plate 24

subject: Didus ineptus

description and notes: 1ithograph; printed by 11 . \& N. Hanhart; plate signed from nat. on stone by J. Erxleben

article: Owen, [Professor]. "On the osteology of the dodo (Didus ineptus, Linn.)." 6:49-85.

Plate 30

subject: Cygnus musicus?; Cygnus falconeri, P.; Cygnus olor

description and notes: lithograph; printed by M. \& N. Hanhart; plate signed J. Erxleben, del et lith.

article: Parker, W.K. "On some fossil birds from the Zebbug Cave, Malta." 6:119-124.

Plate 44

subject: Elephas

description and notes: lithograph; printed by $M$. \& N. Hanhart; plate signed J. Erxleben del. et lith.

article: Busk, George. "Description of the remains of three extinct species of elephant, collected by Capt. Spratt, C.B., R.N., in the ossiferous cavern of Zebbug, in the island of Malta; partly from the notes of the late H. Falconer, M.D., F.R.S." $6: 227-306$. 
Plate 45

subject: Elephas melitensis

description and notes: lithograph; printed by $M$. \& $\mathrm{N}$. Hanhart; plate signed J. Erxleben del. et lith.

article: Busk, George. "Description of the remains of three extinct species of elephant, collected by Capt. Spratt, C.B., F.N., in the ossiferous cavern of Zebbug, in the island of Malta; partly from the notes of the late H. Falconer, M.D., F.R.S." $6: 227-306$.

Plate 46

subject: Elephas melitensis

description and notes: lithograph; printed by $M$. \& N. Hanhart; plate signed J. Erxleben del. et lith.

article: Busk, George. "Description of the remains of three extinct species of elephant, collected by Capt. Spratt, C.B., K.N., in the ossiferous cavern of Zebbug, in the island of Malta; partly from the notes of the late H. Falconer, M.D., F.R.S." 6:227-306.

Plate 47

subject: Elephas melitensis; Elephas falconeri description and notes: lithograph; printed by $M$. \& N. Hanhart; plate signed J. Erxleben del. et lith.

article: Busk, George. "Lescription of the remains of three extinct species of elephant, collected by Capt. Spratt, C.B., R.N., in the ossiferous cavern of Zebbug, in the island of Malta; partly from the notes of the late H. Falconer, M.D., F.R.S." $6: 227-306$.

Plate 48

subject: Elephas melitensis

description and notes: lithograph; printed by $M$. \& $\mathrm{N}$. Hanhart; plate signed J. Erxleben del. et lith.

article: Busk, George. "Description of the remains of three extinct species of elephant, collected by Capt. Spratt, C.B., R.N., in the ossiferous cavern of Zebbug, in the island of Malta; partly from the notes of the late H. Falconer, M.D., F.R.S." 6:227-306. 


\section{Plate 49}

subject: Elephas falconeri

description and notes: lithograph; printed by M. \& N. Hanhart; plate signed From nat on Stone by J. Erxleben

article: Busk, George. "Description of the remains of three extinct species of elephant, collected by Capt. Spratt, C.B., R.N., in the ossiferous cavern of Zebbug, in the island of Malta; partly from the notes of the late H. Falconer, M.D., F.R.S." $6: 227-306$.

\section{Plate 50}

subject: Elephas falconeri

description and notes: lithograph; printed by M. \& N. Hanhart; plate signed J. Erxleben del. et lith.

article: Busk, George. "Description of the remains of three extinct species of elephant, collected by Capt. Spratt, C.B., R.N., in the ossiferous cavern of Zebbug, in the island of Malta; partly from the notes of the late H. Falconer, M.D., F.R.S." $6: 227-306$.

Plate 51

subject: Elephas falconeri; Elephas melitensis; Hippopotamus?

description and notes: lithograph; printed by $M$. \& N. Hanhart; plate signed From life on Stone by J. Erxleben

article: Busk, George. "Description of the remains of three extinct species of elephant, collected by Capt. Spratt, C.B., R.N., in the ossiferous cavern of Zebbug, in the island of Malta; partly from the notes of the late H. Falconer, M.D., F.R.S." $6: 227-306$.

\section{Plate 52}

subject: Elephas falconeri

description and notes: lithograph; printed by $M$. \& N. Hanhart; plate signed J. Erxleben del. et lith.

article: Busk, George. "Description of the remains of three extinct species of elephant, collected by Capt. Spratt, C.B., R.N., in the ossiferous cavern of Zebbug, in the island of Malta; partly from the notes of the late H. Falconer, M.D., F.R.S." 6:227-306. 
Plate 53

subject: Elephas melitensis?; Elephas falconeri?

description and notes: lithograph; printed by $M$. \& N. Hanhart; plate signed J. Erxleben del. et lith.

article: Busk, George. "Description of the remains of three extinct species of elephant, collected

by Capt. Spratt, C.B., R.N., in the ossiferous cavern of Zebbug, in the island of Malta; partly from the notes of the late H. Falconer, M.D., F.R.S." $6: 227-306$.

Plate 91

subject: Rhinochetus jubatus

description and notes: 1ithograph; printed by $M$. \&

$N$. Hanhart; plate signed From liature on Stone by

$\mathrm{J}$ : Erxleben; depicts articulated skeleton;

figure shown natural size

article: Parker, W.K. "On the osteology of the kagu

(Rhinochetus jubatus)." 6:501-521.

Plate 92

subject: Rhinochetus jubatus

description and notes: 1ithograph; printed by $M$. \&

N. Hanhart; plate signed From liature on Stone by

$\mathrm{J}$. Erxleben; depicts various parts of the

skeleton; figures shown natural size

article: Parker, W.K. "On the osteology of the kagu

(Rhinochetus jubatus)." 6:501-521.

Volume 7 (1872)

Plate 7

subject: Dinornis elephantopus

description and notes: lithograph; printed by M. \&

$\mathrm{N}$. Hanhart; plate signed From nature on stone by

J. Erxleben; double-page folded plate

article: Owen, [Professor]. "On Dinornis (Part

XIII.): containing a description of the sternum

in Dinornis elephantopus and D. rheides, with notes on that bone in $D$. crassus and $D$. casuarinus." 7:115-122.

Plate 8

subject: Dinornis rheides

description and notes: lithograph; printed by M. \&

$\mathrm{N}$. Hanhart; plate signed From nature on stone by

$\mathrm{J}$. Erxleben

article: Owen, [Professor]. "On Dinornis (Part

XIII.): containing a description of the sternum

in Dinornis elephantopus and D. rheides,

with notes on that bone in D. crassus and D.

casuarinus." 7:115-122. 
Plate 9

subject: Dinornis rheïdes

description and notes: lithograph; printed by $M$. \& $N$. Hanhart; plate signed From nature on stone by J. Erxleben

article: Uwen, [Professor]. "On Dinornis (Fart XIII.): containing a description of the sternum in Dinornis elephantopus and D. rheides, with notes on that bone in D. crassus and D. casuarinus." 7:115-122.

Plate 11

subject: Dinornis crassus

description and notes: lithograph; printed by M. \& Iv. Hanhart; plate signed J. Erxleben from nat. on stone

article: Owen, [Professor]. "Un Dinornis (Part XIV.): containing contributions to the craniology of the genus, with a description of the fossil cranium of Dasornis londinensis, Ow., from the London Clay of Sheppey." 7:123-150.

Plate 16

subject: Dasornis londinensis

description and notes: lithograph; printer not given; plate signed on stone by J. Erxleben article: Owen, [Professor]. "On Dinornis (Fart XIV.): containing contributions to the craniology of the genus, with a description of the fossil cranium of Dasornis londinensis, Ow., from the London Clay of Sheppey." 7:123-150.

Plate 40

subject: Aptornis defossor

description and notes: lithograph; printed by $M$. \& N. Hanhart; plate signed Froni nat. on stone by J. Erxleben

article: Owen, [Professor]. "Cn Dinornis (Part XV.): containing a description of the skull, femur, tibia, fibula, and metatarsus of Aptornis defossor, Owen, from near Oamaru, Middle Island, New Zealand; with additional observations on Aptornis otidiformis, on Notornis mantellii, and on Dinornis curtus." $7: 353-380$. 
Plate 41

subject: Aptornis defossor

description and notes: lithograph; printed by $\mathrm{N}$. \&

$\mathrm{N}$. Hanhart; plate signed From nat. on stone by

J. Erxleben

article: Owen, [Professor]. "Cn Dinornis (Part

XV.): containing a description of the skull,

femur, tibia, fibula, and metatarsus of

Aptornis defossor, Owen, from near Oamaru, Middle Island, New Zealand; with additional observations on Aptornis otidiformis, on Notornis mantellii, and on Dinornis curtus." $7: 353-380$.

Plate 42

subject: Aptornis; Cnemiornis; Notornis

description and notes: 1ithograph; printed by $M$. \& $\mathrm{N}$. Hanhart; plate signed From nat. on stone by

J. Erxleben

article: Owen, [Professor]. "On Dinornis (Part $\mathrm{XV}$.$) : containing a description of the skul1,$ femur, tibia, fibula, and metatarsus of Aptornis defossor, Owen, from near Oamaru, Middle Island, New Zealand; with additional observations on Aptornis otidiformis, on Notornis mantellii, and on Dinornis curtus." $7: 353-380$.

Plate 43

subject: Aptornis defossor

description and notes: lithograph; printed by $M$. \&

$N$. Hanhart; plate signed From nat. on stone by

J. Erxleben

article: Owen, [Professor]. "On Dinornis (Part $\mathrm{XV}$.$) : containing a description of the skul1,$ femur, tibia, fibula, and metatarsus of Aptornis defossor, Owen, from near Oamaru, Middle Island, New Zealand; with additional observations on Aptornis otidiformis, on Notornis mantellii, and on Dinornis curtus." $7: 353-380$.

Plate 44

subject: Aptornis defossor; Aptornis otidiformis; Dinornis curtus

description and notes: 1ithograph; printed by $M$. \& $\mathrm{N}$. Hanhart; plate signed From nat. on stone by J. Erxleben

article: Owen, [Professor]. "On Dinornis (Part XVI.):.containing notices of the internal organs of some species, with a description of the brain and some nerves and muscles of the head of the Apteryx australis." 7:381-396. 
Plate 47: "Tracheal rings, Dinornis"

subject: Dinornis crassus; Dinornis rheides;

Dinornis elephantopus?; Dinornis ingens?;

Dinornis robustus?

description and notes: lithograph; printed by $\mathrm{N}$ \& $\&$

N. Hanhart; plate signed From nat. on Stone by

J. Erxleben

article: Cwen, [Professor]. "On Dinornis (Part XVI.): containing notices of the internal organs of some species, with a description of the brain and some nerves and muscles of the head of the Apteryx australis." 7:381-396.

Plate 64

subject: Didus ineptus

description and notes: 1ithograph; printed by II. \& $N$. Hanhart; plate signed On Stone by $J$.

Erxleben; shows articulated skeleton; figure shown $1 / 3$ natural size

article: Owen, [Professor]. "On the dodo (Part II.). Notes on the articulated skeleton of the dodo (Didus ineptus, Linn.) in the British Museum." $7: 513-525$.

Plate 65

subject: Didus ineptus

description and notes: lithograph; printed by $M$. \& $\mathrm{N}$. Hanhart; plate signed On Stone by J.

Erxleben; shows articulated skeleton,

three-quarter view; figure shown $1 / 3$ natural size article: Owen, [Professor]. "On the dodo (Part

II.). Notes on the articulated skeleton of the dodo (Didus ineptus, Linn.) in the British Museum." $7: 513-525$.

\section{Volume 8 (1874)}

Plate 14

subject: Aptornis defossor

description and notes: lithograph; printed by $M$. \&

$\mathrm{N}$. Hanhart; plate signed From liature on Stone by

J. Erxleben

article: Owen, [Professor]. "On Dinornis (Part

XVII.): containing a description of the sternum and pelvis, with an attempted restoration, of Aptornis defossor, Ow." 8:119-126. 
Plate 15

subject: Aptornis defossor

description and notes: lithograph; printed by M.\&

N. Hanhart; plate signed Fron. Nature on Stone by

J. Erxleben

article: Owen, [Professor]. "On Dinornis (Part

$\lambda$ VII.): containing a description of the sternum and pelvis, with an attempted restoration, of

Aptornis defossor, Ow." 8:119-126.

Plate 39: "Deep Sea Corals"

subject: Flabellum distinctum; Flabellum

laciniatum

description and notes: lithograph; printed by M. \&

$\mathrm{N}$. Hanhart; plate signed From nat. on Stone by

J. Erxleben

article: Duncan, P. Martin. "A description of the Madreporaria dredged up during the expeditions of H.M.S. 'Porcupine' in 1869 and $1870 . "$

$8: 303-344$.

Plate 40: "Deep Sea Corals"

subject: Caryophyllia abyssorum; Caryophyllia

cylindracea; Caryophyllia vermiformis

description and notes: lithograph; printed by $M$. \&

N. Hanhart; plate signed From nat. on Stone by

J. Erxleben

article: Duncan, P. Martin. "A description of the Nadreporaria dredged up during the expeditions of H.M.S. 'Porcupine' in 1869 and $1870 . "$

$8: 303-344$.

Plate 42: "Deep Sea Corals"

subject: Lophohelia prolifera var. gracilis;

Caryophyllia pourtalesi; Solenosmilia

variabilis

description and notes: 1ithograph; printed by Mi. \&

N. Hanhart; plate signed From nat. on Stone by

J. Erxleben

article: Duncan, P. Martin. "A description of the Madreporaria dredged up during the expeditions of H.M.S. 'Porcupine' in 1869 and 1870."

$8: 303-344$.

Plate 43: "Deep Sea Corals"

subject: Caryophyllia arcuata; Paracyathus

agassizi; Paracyathus striatus;

Balanophyllia socialis

description and notes: 1ithograph; printed by M. \&

$\mathrm{N}$. Hanhart; plate signed From nat. on Stone by

J. Erxleben

article: Duncan, P. Martin. "A description of the Madreporaria dredged up during the expeditions of H.M.S. 'Porcupine' in 1869 and $1870 . "$

$8: 303-344$. 
Plate 45: "Deep Sea Corals"

subject: Amphihelia oculata; Amphihelia ramea

description and notes: 1ithograph; printed by M. \&

$\mathrm{N}$. Hanhart; plate signed From nat. on Stone by

J. Erxleben

article: Duncan, P. Martin. "A description of the Madreporaria dredged up during the expeditions of H.M.S. 'Porcupine' in 1869 and 1870." $8: 303-344$.

Plate 46: "Deep Sea Corals"

subject: Amphihelia ramea

description and notes: lithograph; printed by $M$. \&

N. Hanhart; plate signed From nat. on Stone by

J. Erxleben

article: Duncan, P. Martin. "A description of the Madreporaria dredged up during the expeditions of H.M.S. 'Porcupine' in 1869 and $1870 . "$

$8: 303-344$.

Plate 49: "Deep Sea Corals"

subject: Stylaster gemmascens; Pliobothrus

symmetricus; Balanophyllia cellulosa; Fungia symmetrica

description and notes: 1ithograph; printed by $M$. \&

$\mathrm{N}$. Hanhart; plate signed From nat. on Stone by

J. Erxleben

article: Duncan, P. Martin. "A description of the Madreporaria dredged up during the expeditions of H.M.S. 'Porcupine' in 1869 and $1870 . "$

$8: 303-344$.

Plate 58

subject: Dinornis gravis

description and notes: lithograph; printed by $M_{1}$ \&

$N$. Hanhart; plate signed from nat. on Stone by

J. Erxleben

article: Owen, [Professor]. "On Dinornis (Part

XVIII.): containing a description of the pelvis and bones of the leg of Dinornis gravis."

$8: 361-380$.

Plate 59

subject: Dinornis gravis; Dromaius

novae-hollandiae

description and notes: 1ithograph; printed by $M$. \&

$N$. Hanhart; plate signed from nat. on stone by

J. Erxleben; two-page plate

article: Owen, [Professor]. "On Dinornis (Part

XVIII.): containing a description of the pelvis and bones of the leg of Dinornis gravis."

$8: 361-380$. 
Plate 60

subject: Dinornis gravis

description and notes: lithograph; printed by $N$. \&

N. Hanhart; plate signed from Nature on stone by

J. Erxleben

article: Owen, [Frofessorj. "Un Dinornis (Part

XVIII.): containing a description of the pelvis and bones of the leg of Dinornis gravis.' $8: 361-380$.

Plate 61

subject: Dinornis gravis

description and notes: 1ithograph; printed by $M$. \& $\mathrm{N}$. Hanhart; plate signed from Nat. on Stone by J. Erxleben

article: Owen, [Professor]. "On Dinornis (Part XVIII.): containing a description of the pelvis and bones of the leg of Dinornis gravis." $8: 361-380$.

Volume 9 (1877)

Plate 74

subject: Macropus (Osphranter) rufus

description and notes: lithograph; printed by M. \& $N$. Hanhart; plate signed From nat. on Stone by J. Erxleben

article: Gwen, [Professor]. "Cn the osteology of the Marsupialia. (Part V.) Fam. Poephaga, genus Macropus. $9: 417-446$.

Plate 75

subject: Macropus (Osphranter) rufus

description and notes: 1ithograph; printed by M. \& $N$. Hanhart; plate signed From nat. on Stone by J. Erxleben

article: Owen, [Professor]. "On the osteology of the Marsupialia. (Part V.) Fam. Poephaga, genus Macropus. $9: 417-446$.

Plate 76

subject: Macropus (Osphranter) rufus

description and notes: 1ithograph; printed by $M$. \& $N$. Hanhart; plate signed From nat. on stone by J. Erxleben

article: Owen, [Professor]. "On the osteology of the Marsupialia. (Part V.) Fam. Poephaga, genus Macropus. 9:417-446. 
Plate 77

subject: Macropus (Osphranter) rufus

description and notes: lithograph; printed by M. \& $\mathrm{N}$. Hanhart; plate signed From nat. on stone by J. Erxleben

article: Owen, [Professor]. "On the osteology of the Marsupialia. (Part V.) Fam. Poephaga, genus Macropus." $9: 417-446$.

Plate 78

subject: Macropus (Osphranter) rufus

description and notes: lithograph; printed by $M$. \& $\mathrm{N}$. Hanhart; plate signed From nat. on stone by J. Erxleben

article: Owen, [Professor]. "Un the osteology of the Marsupialia. (Part V.) Fam. Poephaga, genus Macropus." S:417-446.

Plate 79

subject: Macropus (Osphranter) rufus

description and notes: lithograph; printed by M. \& N. Hanhart; plate signed From nat. on stone by

J. Erxleben; oversize plate, folded

article: Owen, [Professor]. "On the osteology of the Marsupialia. (Part V.) Fam. Poephaga, genus Macropus." 9:417-446.

Plate 80

subject: Macropus (Osphranter) rufus

description and notes: lithograph; printed by $M$. \& $N$. Hanhart; plate signed From nat. on stone by

J. Erxleben; oversize plate, folded

article: Owen, [Professor]. "On the osteology of the Marsupialia. (Part V.) Fam. Poephaga, genus Macropus." 9:417-446.

Plate 81

subject: Macropus (Osphranter) rufus

description and notes: lithograph; printed by M. \& $\mathrm{N}$. Hanhart; plate signed From nat. on stone by J. Erxleben

article: Owen, [Professor]. "On the osteology of the Marsupialia. (Part V.) Fam. Poephaga, genus Macropus." 9:417-446.

Plate 82

subject: Macropus (Osphranter) rufus

description and notes: lithograph; printed by M. \& N. Hanhart; plate signed From nat. on stone by J. Erxleben

article: Owen, [Professor]. "On the osteology of the Marsupialia. (Part V.) Fam. Poephaga, genus Macropus." 9:417-446. 
Plate 8's

subject: Macropus (Osphranter) rufus

description and notes: lithograph; printed by $\Lambda$. \& $\mathrm{N}$. Hanhart; plate signed From nat. on Stone by J. Łrxleben

article: Owen, [Protessor]. "On the osteology of the Narsupialia. (Part V.) Fam. Yoephaga, genus Macropus." 9:417-446.

Volume $10(1879)$

\section{Plate 33}

subject: Dromornis australis

description and notes: 1ithograph; printed by M. \& N. Hanhart; plate signed From nat. on stone by J. Erxleben

article: Owen, [Professor]. "On Dinornis (Part XXI.): containing a restoration of the skeleton of Dinornis maximus, Owen. With an appendix, on additional evidence of the genus Dromornis in Australia." 10:147-188.

Plate 43: "New Corals of the Porcupine Expedition" subject: Caryophyllia pourtalesi; Caryophyllia inskipi; Caryophyllia calveri; Caryophyllia carpenteri; Caryophyllia simplex

description and notes: lithograph; printed by Hanhart; plate signed From nat. on stone by $\mathrm{J}$. Erxleben

article: Duncan, P. Martin. "A description of the Madreporaria dredged up during the expedition of H.M.S. 'Porcupine in 1869 and 1870 . Part II." $10: 235-249$.

Plate 44: "New Corals of the Porcupine Expedition" subject: Paracyathus insignis; Paracyathus striatus; Paracyathus monilis; Paracyathus inornatus; Paracyathus humilis; Paracyathus africanus; Paracyathus costatus

description and notes: lithograph; printed by Hanhart; plate signed From nat. on stone by $\mathrm{J}$. Erxleben

article: Duncan, P. Martin. "A description of the Madreporaria dredged up during the expedition of H.M.S. "Porcupine in 1869 and 1870. Part II." $10: 235-249$. 
Plate 45: "New Corals of the Porcupine Expedition" subject: Bathycyathus minor; Bathycyathus atlanticus; Flabellum minus; Blastosmilia pourtalesi; Gemmulatrochus simplex

description and notes: lithograph; printed by Hanhart; plate signed From nat. on stone by $\mathrm{J}$. Erxleben

article: Duncan, P. Martin. "A description of the Madreporaria dredged up during the expedition of H.M.S. "Porcupine in 1869 and 1870 . Part II." $10: 235-249$.

Volume 11 (1885)

Plate 23

subject: Tritaxeopus cornutus Ow.

description and notes: hand-colored lithograph;

printed by Hanhart; figure shown $3 / 4$ natural size article: Owen, [Professor]. "Descriptions of some new and rare Cephalopoda. (Part II.)." $11: 131-170$.

Plate 28

subject: Ommastrephes ensifer

description and notes: hand-colored lithograph; printed by Hanhart; plate signed On stone by $J$. Erxleben; figure shown $3 / 4$ natural size

article: Owen, [Professor]. "Descriptions of some new and rare Cephalopoda. (Part II.)." 11:131-170.

Plate 34

subject: Plectoteuthis grandis

description and notes: lithograph; printed by

Hanhart; plate signed From nat. on stone by $J$. Erxleben; figure of cephalic arm and vela shown natural size

article: Owen, [Professor]. "Descriptions of some new and rare Cephalopoda. (Part II.)." 11:131-170.

Flate 35

subject: Plectoteuthis grandis

description and notes: lithograph; printed by

Hanhart; plate signed From nat. on stone by $J$. Erxleben; figure of cephalic arm and vela shown natural size

article: Owen, [Professor]. "Lescriptions of some new and rare Cephalopoda. (Part II.)."

$11: 131-170$. 
Plate 51

subject: Dinornis parvus

description and notes: lithograph; printed by $M$. \& N. Hanhart; plate signed From nat. on stone by

J. Erxleben

article: Owen, [Professor]. "On Dinornis (Fart

XXIII.): containing a description of the

skeleton of Dinornis parvus, Owen." 11:233-256.

Plate 52

subject: Dinornis parvus

description and notes: lithograph; printed by N. \& $N$. hanhart; plate signed From nat. on stone by

J. Erxleben; skull shown natural size

article: Owen, [Professor]. "On Dinornis (Part

XXIII.): containing a description of the

skeleton of Dinornis parvus, Uwen." 11:233-256.

Plate 53

subject: Dinornis parvus

description and notes: lithograph; printed by M. \&

$N$. Hanhart; plate signed From nat., on Stone, by

J. Erxleben; figure of pelvis shown $2 / 3$ natural size

article: Owen, [Professor]. "On Dinornis (Part

XXIII.): containing a description of the

skeleton of Dinornis parvus, Owen." 11:233-256.

Plate 54

subject: Dinornis parvus

description and notes: lithograph; printed by $M$. \&

$N$. Hanhart; plate signed From nat. on stone by

$J$. Erxleben; pelvis and caudal vertebrae shown

article: Owen, [Professor]. "On Dinornis (Fart

XXIII.): containing a description of the

skeleton of Dinornis parvus, Owen." 11:233-256.

Plate 55

subject: Dinornis parvus

description and notes: lithograph; printed by $M$. \&

N. Hanhart; plate signed From nat., on Stone, by

$\mathrm{J}$. Erxleben; sternum shown natural size

article: Owen, [Professor]. "On Dinornis (Yart

XXIII.): containing a description of the

skeleton of Dinornis parvus, Owen." 11:233-256.

Plate 56

subject: Dinornis parvus

description and notes: lithograph; printed by M. \&

$N$. Hanhart; plate signed From nat. on Stone by

J. Erxleben; femur shown natural size

article: Owen, [Professor]. "On Dinornis (Part

XXIII.): containing a description of the

skeleton of Dinornis parvus, Owen." 11:233-256. 
Plate 57

subject: Dinornis parvus

description and notes: lithograph; printed by $\Lambda_{1}$ \&

$\mathrm{N}$. Hanhart; plate signed From nat. on Stone, by

J. Erxleben; left foot shown natural size

article: Owen, [Professor]. "On Dinornis (Part

XXIII.): containing a description of the

skeleton of Dinornis parvus, Owen."11:233-256.

Plate 58

subject: Dinornis parvus

description and notes: 1ithograph; printed by $M . \&$

N. Hanhart; plate signed From nat. on Stone by

$\mathrm{J}$. Erxleben; figure shown $1 / 4$ natural size

article: Owen, [Professor]. "On Dinornis (Part

XXIII.): containing a description of the

skeleton of Dinornis parvus, Owen." 11:233-256.

Plate 59

subject: Dinornis didinus

description and notes: lithograph; printed by

Hanhart; plate signed From nat. on Stone by J.

Erxleben; head shown natural size

article: Owen, [Professor]. "On Dinornis (Fart

XXIV.): containing a description of the head and

feet, with their dried integuments, of an

individual of the species Dinornis didinus,

Owen." 11:257-261.

Plate 60

subject: Dinornis didinus

description and notes: lithograph; printed by

Hanhart; plate signed From nat. on Stone by $\mathrm{J}$.

Erxleben; foot shown natural size

article: Owen, [Professor]. "On Dinornis (Part

XXIV.): containing a description of the head and

feet, with their dried integuments, of an

individual of the species Dinornis didinus,

Owen." 11:257-261.

Plate 61

subject: Dinornis didinus

description and notes: 1ithograph; printed by

Hanhart; plate signed From nat. on Stone by J.

Erxleben; foot shown natural size

article: Owen, [Professor]. "On Dinornis (Part

XXIV.): containing a description of the head and

feet, with their dried integuments, of an

individual of the species Dinornis didinus, Owen." 11:257-261. 
Volume 12 (1890)

Plate 1: "Sternum of Dinornis elephantopus" subject: Dinornis elephantopus

description and notes: lithograph; printed by

Hanhart; plate signed From nat on stone by $\mathrm{J}$.

Erxleben; figure shown natural size; double-pagt plate

article: (wen, Kichard. "On Dinornis (Hart XXV.):

containing a description of the sternum of

Dinornis elephantopus." 12:1-3.

Plate 28

subject: Gastornis klaasseni Newton; Cereopsis;

Larus argentatus

description and notes: lithograph; printed by

Hanhart; plate signed From Nature on Stone by J.

Erxleben; figures shown $1 / 2$ or full natural size article: Newton, E.T. "On the remains of a gigantic species of bird (Gastornis klaasseni, n.sp.) from the Lower Eocene beds near Croydon." $12: 143-160$.

Plate 29

subject: Gastornis klaasseni Niewton

description and notes: lithograph; printed by

Hanhart; plate signed From llature on Stone by J. Erxleben; figures shown $1 / 2$ natural size

article: Newton, E.T. "On the remains of a gigantic species of bird (Gastornis klaasseni, n.sp.) from the Lower Eocene beds near Croydon." $12: 143-160$.

Plate 31

subject: Dinornis oweni

description and notes: lithograph; printed by $M$. \&

N. Hanhart; plate signed From nat. on Stone by

$J$. Erxleben; figures shown natural size

article: Haast, Julius von. "On Dinornis oweni, a new species of the Dinornithidae, with some remarks on D. curtus." 12:171-182.

Plate 32

subject: Dinornis oweni

description and notes: lithograph; printed by $M$. \&

N. Hanhart; plate signed From nat. on Stone by

J. Erxleben; figures shown natural size

article: Haast, Julius von. "On Dinornis oweni, a new species of the Dinornithidae, with some remarks on D. curtus." 12:171-182. 
FAWCETT, Lt. Col. J. Malcolm

Volume 15 (1901)

Plate 46: "Transformations of South-African Rhopalocera" subject: Acraea petroaea Boisd. [larva and pupa]; Acraea encedon Linn. [larva and pupa]; Acraea rahira Boisd. [larva and pupa]; Acraea buxtoni Butler [larva and pupa]; Junonia cebrene Trimen [pupa]; Junonia clelia Cramer [larva and pupa]; Charaxes candiope Godart [larva and pupa]; Pieris severina Cramer [larva and pupa]; Pieris hellica Linn. [larva and pupa]; Papilio policenes Cramer [larva and pupa]; Papilio brasidas Felder [ larva and pupaj; Papilio morania Angas [larva and pupa]; Papilio nireus var. lyaeus Cramer [larva]; Papilio demodocus Esper [larva and pupa] description and notes: chromolithograph; printed by West, Newman; plate signed J.M.F. del., F.C. Knight lith.

article: Fawcett, J. Malcolm. "Notes on the transformations of some South-African Lepidoptera." 15:291-322.

Plate 47: "Transformations of South-African Heterocera" subject: Actias mimosae [larva and cocoon];

Nudaurelia wahlbergi Wallengren [larva and pupa]; Gynanisa maia Klug [larva and pupa]; Bunaea caffraria Stoll [larva]; Urota sinope [larva and pupa]; Pseudaphelia apollinaris Westwood [larva and pupa]; Eusemia butleri Walker [larva and pupa]; Hypsa aphidas Hopff. [larva]; Chaerocampa capensis Linnaeus [larva and pupa]

description and notes: chromolithograph; printed by West, Newman; plate signed J.M.F. del., F.C. Knight lith.

article: Fawcett, J. Malcolm. "Notes on the transformations of some South-African Lepidoptera." 15:291-322. 
Plate 48: "Transformations of South-African Heterocera" subject: Chaerocampa balsaminae Boisduval [ larva and pupa]; Chaerocampa osiris Dalman [larva and pupa]; Lophostethus dumolinii Latreille [larva and pupa]; Protoparce mauritii Butler [larva and pupa]; Cephonodes hylas Linn. [ larva and pupa]

description and notes: chromolithograph; printed by West, Newman; plate signed J.M.F. del., F.C. Knight lith.

article: Fawcett, J. Malcolm. "Notes on the transformations of some South-African Lepidoptera." 15:2y1-322.

Plate 49: "Transformations of South-African Heterocera" subject: Chaerocampa idricus Drury Llarva and pupa]; Gonometa postica Walker [larva and cocoon]; Ludia smilax Westwood [larva and cocoon]; Phissama flava Walker [larva]; Phissama screabile Walker [larva]; Taeniopyga sylvina Stoll [larva and pupa]; Dulichia fasciata Walker [larva]; Spilosoma puella Druce [larva]; Agrotis segetis Schiff [larva]; Glottula pancratii Cyr. [larva]; Dasychira georgiana [larva and pupa]; Polydesma glaucinans Guen. [ larva and pupa]; Boarmia acaciaria Boisduval [ larva]; Earias insulana Boisduval [larva and cocoon]; Zygaena (Anteris) ampla Walker [larva and cocoon]

description and notes: chromolithograph; printed by West, Newman; plate signed J.M.F. del., F.C. Knight lith.

article: Fawcett, J. Malcolm. "Notes on the transformations of some South-African Lepidoptera." 15:291-322. 
Volume 17 (1903-1906)

Plate 6: "Transformations of South African Lepidoptera" subject: Eurytela hiarbas [pupa]; Byblia ilithyia [pupa]; Crenis boisduvali [larva]; Crenis natalensis [larva and pupa]; Charaxes varanes [pupa]; Pieris gidica [larva and pupa]; Nudaurelia belina [larva and pupa]; Usta terpischore [larva]; Copaxa flavinata [larva]; Cirina forda [larva and pupa]; Bunaea tyrrhena [larva and pupa]; Henucha smilax [larva]; Henucha delegorguei [larva]; Phyllalia flavicostata [female, larva and pupa]; Phyllalia patens [male, larva and cocoon]

description and notes: chromolithograph; printed by West, Newman; plate signed J.M. Fawcett del., E.C. Knight lith.

article: Fawcett, J. Malcolm. "Notes on the transformation of some South-African Lepidoptera." 17:165-190.

Plate 7: "Transformations of South African Lepidoptera" subject: Ambulyx postica Walker [larva]; Polyptychus grayi Walker [larva and pupa];

Chaerocampa orpheus [larva and pupa]; Hyloicus juniperi [larva]; Lophuron marginatum [larva]; Nephele variegata [pupa]; Metarctia meteus [male and female]; Estigmene dissimilis [larva and pupa]; Estigmene atropunctata [female, larva and pupa]; Rhodogastria astreas var. bauri;

Metanastria aculeata [male, larva and pupa]

description and notes: chromolithograph; printed by West, Newman; plate signed J.M. Fawcett del., E.C. Knight lith.

article: Fawcett, J. Malcolm. "Notes on the transformation of some South-African Lepidoptera." 17:165-190.

Plate 8: "Transformations of South African Lepidoptera" subject: Trabala pallida [female, larva and cocoon]; Euchloris devocata [larva and pupa]; Petovia dichroaria [pupa]; Callioratis bellatrix [pupa]; Egybolis vaillantina [larva]; Ophiusa indeterminata [larva and pupa]; Rhonidophora cinctigutta [larva]; Chaerocampa eson [larva]

description and notes: chromolithograph; printed by West, Newman; plate signed J.N. Fawcett del., E.C. Knight lith.

article: Fawcett, J. Malcolm. "Notes on the transformation of some South-African Lepidoptera." 17:165-190. 
FLOWER, Sir William Henry (1831-1894)

\section{Volume 5 (1866)}

Plate 27

subject: Stenops Javanicus; Lemur nigrifrons;

Nyctipithecus trivirgatus; Callithrix

moloch; Felis domestica

description and notes: lithograph; printed by $M$. \& N. Hanhart; plate signed W.H. Flower delt., J. Erxleben lith.

article: Flower, William Henry. "On the brain of the Javan loris (Stenops javanicus Illig.)." 5: 103-111. 
FORD, George Henry (1809-1876)

Volume 4(1862)

Plate 26

subject: Troglodytes gorilla

description and notes: lithograph; printed by Ford \& West; plate signed G.H. Ford, del. et lith.; folded plate; gives view of base of skull article: Owen, [Professor]. "Osteological contributions to the natural history of the chimpanzees (Troglodytes) and orangs

(Pithecus). No. IV. Descriptions of the cranium of an adult male gorilla from the River Danger, west coast of Africa, indicative of a variety of the great chimpanzee (Troglodytes gorilla), with remarks on the capacity of the cranium and other characters shown by sections of the skull, in the orangs (Pithecus), chimpanzees (Troglodytes), and in different varieties of the human race." $4: 75-88$.

\section{Plate 27}

subject: Troglodytes gorilla

description and notes: lithograph; printed by Ford \& West; plate signed G.H. Ford, del. et lith.; folded plate; gives view of front of skull

article: Owen, [Professor]. "Osteological contributions to the natural history of the chimpanzees (Troglodytes) and orangs

(Pithecus). No. IV. Descriptions of the cranium of an adult male gorilla from the River Danger, west coast of Africa, indicative of a variety of the great chimpanzee (Troglodytes gorilla), with remarks on the capacity of the cranium and other characters shown by sections of the skull, in the orangs (Pithecus), chimpanzees (Troglodytes), and in different varieties of the human race." 4:75-88. 
Plate 28

subject: Troglodytes gorilla

description and notes: 1ithograph; printed by Ford \& West; plate signed G.H. Ford, del. et lith.; gives view of lateral cross-section of skull

article: Owen, [Professor]. "Osteological contributions to the natural history of the chimpanzees (Troglodytes) and orangs (Pithecus). No. IV. Descriptions of the cranium of an adult male gorilla from the Fiver Danger, west coast of Africa, indicative of a variety of the great chimpanzee (Troglodytes gorilla), with remarks on the capacity of the cranium and other characters shown by sections of the skull, in the orangs (Pithecus), chimpanzees (Troglodytes), and in different varieties of the human race." 4:75-88.

Plate 29

subject: Pithecus satyrus [male and female] description and notes: lithograph; printed by Ford $\&$ West; plate signed G.H. Ford, ad. nat lith.; gives view of lateral cross-section of skulls article: Owen, [Professor]. "Csteological contributions to the natural history of the chimpanzees (Troglodytes) and orangs

(Pithecus). No. IV. Descriptions of the cranium of an adult male gorilla from the Fiver Danger, west coast of Africa, indicative of a variety of the great chimpanzee (Troglodytes gorilla), with remarks on the capacity of the cranium and other characters shown by sections of the skull, in the orangs (Pithecus), chimpanzees (Troglodytes), and in different varieties of the human race." 4:75-88.

Plate 30

subject: Homo sapiens var. melanoides

description and notes: lithograph; printed by Ford \& West; plate signed G.H. Ford, ad. nat lith.; gives view of lateral cross-section of skull

article: Owen, [Professor]. "Osteological contributions to the natural history of the chimpanzees (Troglodytes) and orangs (Pithecus). No. IV. Descriptions of the cranium of an adult male gorilla from the Piver Danger, west coast of Africa, indicative of a variety of the great chimpanzee (Troglodytes gorilla), with remarks on the capacity of the cranium and other characters shown by sections of the skull, in the orangs (Pithecus), chimpanzees (Troglodytes), and in different varieties of the human race." 4:75-88. 
Plate 31: "Maxilla Inferior"

subject: Troglodytes gorilla; Homo sapiens

description and notes: lithograph; printed by Ford \& West; plate signed G.H. Ford, ad. nat lith.; gives view of side of jaws

article: Owen, [Yrofessor]. "Osteological contributions to the natural history of the chimpanzees (Troglodytes) and orangs (Pithecus). No. IV. Lescriptions of the cranium of an adult male gorilla from the River Danger, west coast of Africa, indicative of a variety of the great chimpanzee (Troglodytes gorilla), with remarks on the capacity of the cranium and other characters shown by sections of the skull, in the orangs (Pithecus), chimpanzees (Troglodytes), and in different varieties of the human race." 4:75-88.

Plate 32: "Maxilla Inferior"

subject: Troglodytes gorilla; Troglodytes niger

description and notes: lithograph; printed by Ford $\&$ West; plate signed G.H. Ford, ad. nat lith.; gives view of top of jaws

article: Owen, [Professor]. "Osteological contributions to the natural history of the chimpanzees (Troglodytes) and orangs

(Pithecus). No. IV. Descriptions of the cranium of an adult male gorilla from the River Danger, west coast of Africa, indicative of a variety of the great chimpanzee (Troglodytes gorilla), with remarks on the capacity of the cranium and other characters shown by sections of the skull, in the orangs (Pithecus), chimpanzees (Troglodytes), and in different varieties of the human race." $4: 75-\delta \delta$.

Plate 48

subject: Pithecus morio [male]

description and notes: lithograph; printed by $W$. West; gives side view of skull

article: Owen, [Professor]. "Osteological contributions to the natural history of the chimpanzees (Troglodytes) and orangs

(Pithecus). No. VI. Characters of the skull of the male Pithecus morio, with remarks on the varieties of the male Pithecus satyrus." 4:165-178. 
Plate 49

subject: Pithecus morio [male]

description and notes: lithograph; printed by $W$. West; gives base view of skull

article: Owen, [Professor]. "Osteological

contributions to the natural history of the chimpanzees (Troglodytes) and orangs

(Pithecus). No. VI. Characters of the skull of the male Pithecus morio, with remarks on the varieties of the male Pithecus satyrus." 4:165-178.

Plate 50

subject: Pithecus satyrus var. pappan;

Pithecus satyrus var. rambi

description and notes: lithograph; printed by $W$. West

article: Owen, [Professor]. "Osteological contributions to the natural history of the chimpanzees (Troglodytes) and orangs

(Pithecus). No. VI. Characters of the skull of the male Pithecus morio, with remarks on the varieties of the male Pithecus satyrus."

4:165-178.

Plate 55

subject: Didus?

description and notes: lithograph; printed by $W$. West

article: Strickland, H.E. "On some bones of birds allied to the dodo, in the collection of the Zoological Society of London." 4:187-196.

Volume 5 (1866)

Plate 7

subject: Troglodytes gorilla; Troglodytes niger; Homo

description and notes: lithograph; printed by $W$. West; plate signed G.H. Ford ad nat. lith.; folded plate

article: Owen, [Professor]. "Osteological

contributions to the natural history of the anthropoid apes. No. VII. Comparison of the bones of the limbs of the Troglodytes gorilla, Troglodytes niger, and of different varieties of the human race; and on the general characters of the skeleton of the gorilla." 5:1-31. 
Plate 8

subject: Troglodytes gorilla; Troglodytes niger; Homo

description and notes: lithograph; printed by $W$. West; plate signed G.H. Ford ad nat. lith.; folded plate

article: Owen, [Professor]. "Osteological contributions to the natural history of the anthropoid apes. No. VII. Comparison of the bones of the limbs of the Troglodytes gorilla, Troglodytes niger, and of different varieties of the human race; and on the general characters of the skeleton of the gorilla." 5:1-31.

Plate 12

subject: Homo; Troglodytes gorilla

description and notes: lithograph; printed by $W$. West; folded plate

article: Cwen, [Professor]. "Osteological contributions to the natural history of the anthropoid apes. No. VII. Comparison of the bones of the limbs of the Troglodytes gorilla, Troglodytes niger, and of different varieties of the human race; and on the general characters of the skeleton of the gorilla." 5:1-31.

Plate 13

subject: Homo; Troglodytes gorilla

description and notes: lithograph; printed by $W$. West; folded plate

article: Owen, [Professor]. "Osteological contributions to the natural history of the anthropoid apes. No. VII. Comparison of the bones of the limbs of the Troglodytes gorilla, Troglodytes niger, and of different varieties of the human race; and on the general characters of the skeleton of the gorilla." 5:1-31.

Plate 45

subject: Troglodytes gorilla

description and notes: Iithograph; printed by $W$. West

article: Owen, [Professor]. "Contributions to the natural history of the anthropoid apes. No. VIII. On the external characters of the gorilla (Troglodytes gorilla, Sav.)." 5:243-284.

Plate 47

subject: Troglodytes gorilla

description and notes: lithograph; printed by $W$. West

article: Owen, [Professor]. "Contributions to the natural history of the anthropoid apes. No. VIII. On the external characters of the gorilla (Troglodytes gorilla, Sav.)." 5:243-284. 
Plate 49

subject: Troglodytes gorilla

description and notes: lithograph; printed by $W$. West; figures shown $3 / 4$ natural size

article: Owen, [Professor]. "Contributions to the natural history of the anthropoid apes. No. VIII. On the external characters of the gorilla (Troglodytes gorilla, Sav.)." 5:243-284.

\section{Volume 6 (1869)}

\section{Plate 2}

subject: Potamogale velox

description and notes: lithograph; printed by $W$. West

article: Allman, George J. "On the characters and affinities of Potamogale, a genus of insectivorous mammals." 6:1-16.

Plate 31

subject: Bombifrons indicus; Halicrosia nigra

description and notes: lithograph; printed by $W$. West; figures shown $1 / 5$ natural size; Halcrosia nigra given on plate as "Halicrosia [sic] frontata"

article: Gray, John Edward. "Synopsis of the species of recent Crocodilians or Emydosaurians, chiefly founded on the specimens in the British Museum and the Royal College of Surgeons." $6: 125-169$.

Plate 32

subject: Mecistops cataphractus; Molinia intermedia

description and notes: 1ithograph; printed by $W$. West; figures shown $1 / 6$ natural size; Molinia intermedia given on plate as "Crocodilus intermedius ${ }^{n}$

article: Gray, John Edward. "Synopsis of the species of recent Crocodilians or Emydosaurians, chiefly founded on the specimens in the British Museum and the Royal College of Surgeons." $6: 125-169$. 
Plate 33

subject: Jacare ocellata

description and notes: lithograph; printed by $W$. West; figure shown natural size

article: Gray, John Edward. "Synopsis of the species of recent Crocodilians or Emydosaurians, chiefly founded on the specimens in the British Museum and the Royal College of Surgeons." $6: 125-169$.

Plate 34

subject: Jacare longiscutata

description and notes: lithograph; printed by $W$. West; figure shown natural size

article: Gray, John Edward. "Synopsis of the species of recent Crocodilians or Emydosaurians, chiefly founded on the specimens in the British Museum and the Royal College of Surgeons." $6: 125-169$.

Plate 65

subject: Centropristis macropoma; Haemulon margaritiferum; Chaetodon humeralis

description and notes: lithograph; printed by $W$. West

article: Guinther, Albert. "An account of the fishes of the states of Central America, based on collections made by Capt. J.M. Dow, F. Godman, Esq., and 0. Salvin, Esq." 6:377-494.

Plate 66

subject: Upeneus tetraspilus; Pseudojulis notospilus; Pristipoma leuciscus

description and notes: lithograph; printed by $W$. West

article: Günther, Albert. "An account of the fishes of the states of Central America, based on collections made by Capt. J.M. Dow, F. Godman, Esq., and 0. Salvin, Esq." 6:377-494.

Plate 67

subject: Corvina chrysoleuca; Corvina vermicularis; Plectropoma afrum

description and notes: lithograph; printed by $W$. West

article: Günther, Albert. "An account of the fishes of the states of Central America, based on collections made by Capt. J.M. Dow, F. Godman, Esq., and 0. Salvin, Esq." 6:377-494. 
Plate 69

subject: Cremnobates monophthalmus; Clinus macrocephalus; Antennarius leopardinus; Trachynotus fasciatus

description and notes: lithograph; printed by W. West

article: Günther, Albert. "An account of the fishes of the states of Central America, based on collections made by Capt. J.M. Dow, F. Godman, Esq., and 0. Salvin, Esq." 6:377-4乌4.

Plate 70

subject: Agonostoma microps; Agonostoma nasutum description and notes: lithograph; printed by $W$. West

article: Ginther, Albert. "An account of the fishes of the states of Central America, based on collections made by Capt. J.M. Dow, F. Godman, Esq., and 0. Salvin, Esq." 6:377-494.

Plate 72

subject: Heros urophthalmus; Heros longimanus; Heros melanurus

description and notes: lithograph; printed by $W$. West

article: Guinther, Albert. "An account of the fishes of the states of Central America, based on collections made by Capt. J.M. Dow, F. Godman, Esq., and 0. Salvin, Esq." 6:377-4G4.

Plate 73

subject: Heros spilurus; Heros aureus; Heros salvini; Heros dovii

description and notes: lithograph; printed by $W$. West

article: Guinther, Albert. "An account of the fishes of the states of Central America, based on collections made by Capt. J.M. Dow, F. Godman, Esq., and 0. Salvin, Esq." 6:377-494.

Plate 74

subject: Platyglossus dispilus; Heros multispinosus; Heros nigrofasciatus; Neetroplus nematopus; Heros godmanni description and notes: lithograph; printed by $W$. West

article: Günther, Albert. "An account of the fishes of the states of Central America, based on collections made by Capt. J.M. Dow, F. Godman, Esq., and 0. Salvin, Esq." 6:377-494. 
Plate 76

subject: Heros trimaculatus

description and notes: lithograph; printed by $W$. West

article: Gunther, Albert. "An account of the fishes of the states of Central America, based on collections made by Capt. J.M. Low, F. Codman, Esq., and 0. Salvin, Esq." 6:377-494.

Plate 77

subject: Heros nicaraguensis; Heros motaguensis; Heros managuens is

description and notes: 1ithograph; printed by $W$. West

article: Günther, Albert. "An account of the fishes of the states of Central America, based on collections made by Capt. J.M. Dow, F. Godman, Esq., and 0. Salvin, Esq." 6:377-494.

Plate 78

subject: Heros intermedius; Heros irregularis; Heros guttulatus

description and notes: lithograph; printed by $\mathrm{W}$. West

article: Ginther, Albert. "An account of the fishes of the states of Central America, based on collections made by Capt. J.M. Dow, F. Godman, Esq., and 0. Salvin, Esq." 6:377-494.

Plate 81

subject: Amiurus meridionalis; Aelurichthys nuchalis

description and notes: lithograph; printed by $W$. West

article: Günther, Albert. "An account of the fishes of the states of Central America, based on collections made by Capt. J.M. Dow, F. Godman, Esq., and 0. Salvin, Esq." 6:377-494.

Plate 82

subject: Chalcinopsis dentex; Characodon lateralis; Gambusia nicaraguensis; Anacyrtus guatemalensis; Haplochilus dovii

description and notes: lithograph; printed by $W$. West

article: Günther, Albert. "An account of the fishes of the states of Central America, based on collections made by Capt. J.M. Dow, F. Godman, Esq., and 0. Salvin, Esq." 6:377-494. 
Plate 83

subject: Exocoetus callopterus

description and notes: lithograph; printed by $W$. West

article: Günther, Albert. "An account of the fishes of the states of Central America, based on collections made by Capt. J.M. Dow, F. Godman, Esq., and O. Salvin, Esq." 6:377-494.

Plate 84

subject: Fundulus labialis [male and female];

Fundulus guatemalensis [male and female];

Fundulus punctatus [male]; Fundulus pachycephalus [male]

description and notes: lithograph; printed by $W$. West

article: Günther, Albert. "An account of the fishes of the states of Central America, based on collections made by Capt. J.M. Dow, F. Godman, Esq., and 0. Salvin, Esq." 6:377-494.

Plate 85

subject: Heros angulifer; Poecilia elongata [female]; Poecilia petenensis [male female] description and notes: lithograph; printed by $W$. West

article: Günther, Albert. "An account of the fishes of the states of Central America, based on collections made by Capt. J.M. Dow, F. Godman, Esq., and 0. Salvin, Esq." 6:377-494.

Plate 86

subject: Mollienesia petenensis [male and female, juvenile male]; Cirrhitichthys rivulatus

description and notes: lithograph; printed by $W$. West

article: Günther, Albert. "An account of the fishes of the states of Central America, based on collections made by Capt. J.H. Dow, F. Godman, Esq., and 0. Salvin, Esq." 6:377-494.

Plate 87

subject: Girardinus pleurospilus; Xiphophorus helleri [female and male]

description and notes: lithograph; printed by $W$. West

article: Günther, Albert. "An account of the fishes of the states of Central America, based on collections made by Capt. J.M. Dow, F. Godman, Esq., and O. Salvin, Esq." 6:377-494. 
Volume 7 (1872)

Plate 66

subject: Pezophaps solitaria; Pezophaps minor; Didus ineptus

description and notes: lithograph; printed by Mintern Bros.

article: Owen, [Frofessor]. "On the dodo (Part

II.). Notes on the articulated skeleton of the dodo (Didus ineptus, Linn.) in the British Museum." 7:513-525. 
FROHAWK, Fredrick William (1861-1946)

\section{Volume 21 (1916-1936)}

Flate 35

subject: Dendrolagus matschiei matschiei

description and notes: chromolithograph; printed by John Bale Sons \& Danielsson; signed "F.W.

Frohawk"; depicts type specimen

article: Kothschild, Lord and Guy Dollman. "The genus Dendrolagus." 21:477-548.

Plate 36

subject: Dendrolagus matschiei matschiei

description and notes: chromolithograph; printed by John Bale Sons \& Danielsson; signed "F.W.

Frohawk"; depicts specimen at the Zoological Gardens

article: Kothschild, Lord and Guy Dollman. "The genus Dendrolagus." 21:477-548.

Plate 37

see Unsigned 21: Plate 37

Plate 38

subject: Dendrolagus goodfellowi shawmayeri

description and notes: chromolithograph; printed by John Bale Sons \& Danielsson; signed "F.W. Frohawk"; depicts co-type specimen

article: Rothschild, Lord and Guy Dollman. "The genus Dendrolagus." 21:477-548.

Plate 39

subject: Dendrolagus dorianus dorianus

description and notes: chromolithograph; printed by John Bale Sons \& Danielsson; signed "F.W. Frohawk"

article: Rothschild, Lord and Guy Dollman. "The genus Dendrolagus." 21:477-548. 
Plate 40

subject: Dendrolagus dorianus ab. 1oc. aureus

description and notes: chromolithograph; printed by John Bale Sons \& Danielsson; signed "F.W. Frohawk"

article: Fothschild, Lord and Guy Dollman. "The genus Dendrolagus." 21:477-548.

Plate 41

subject: Dendrolagus dorianus notatus

description and notes: chromolithograph; printed by John Bale Sons \& Danielsson; signed "F.W.

Frohawk"; depicts type specimen

article: Rothschild, Lord and Guy Dollman. "The genus Dendrolagus." 21:477-548.

Plate 42

subject: Dendrolagus dorianus mayri

description and notes: chromolithograph; printed by John Bale Sons \& Danielsson; signed "F.W.

Frohawk"; depicts type specimen

article: Kothschild, Lord and Guy Dollman. "The genus Dendrolagus." 21:477-548.

Plate 43

subject: Dendrolagus ursinus

description and notes: chromolithograph; printed by John Bale Sons \& Vanielsson; signed "F.W.

Frohawk"; depicts specimens in the Tring Museum and British luseum

article: Kothschild, Lord and Guy Dollman. "The genus Dendrolagus." 21:477-548.

Plate 44

subject: Dendrolagus ursinus

description and notes: chromolithograph; printed by John Bale Sons \& Danielsson; signed "F.W.

Frohawk"; type of Dendrolagus leucogenys Matschie

article: Rothschild, Lord and Guy Dollman. "The genus Dendrolagus." 21:477-548.

Plate 45

subject: Dendrolagus inustus inustus

description and notes: chromolithograph; printed by John Bale Sons \& Danielsson; signed "F.W. Frohawk"; type of Dendrolagus maximus Rothschild

article: Rothschild, Lord and Guy Dollman. "The genus Dendrolagus." 21:477-548. 
Plate 46

subject: Dendrolagus inustus finschi

description and notes: chromolithograph; printed by John Bale Sons \& Danielsson; signed "F.W.

Frohawk"; depicts specimen from Tring Museum

article: Rothschild, Lord and Guy Lollman. "The genus Dendrolagus." 21:477-548.

Plate 47

subject: Dendrolagus inustus keiensis

description and notes: chromolithograph; printed by John Bale Sons \& Danielsson; signed "F.W.

Frohawk"; depicts type specimen

article: Kothschild, Lord and Guy Dollman. "The genus Dendrolagus." 21:477-548.

Plate 48

subject: Dendrolagus inustus keiensis

description and notes: chromolithograph; printed by John Bale Sons \& Lanielsson; signed "F.W.

Frohawk"; depicts specimen in Tring Museum

article: Rothschild, Lord and Guy Dollman. "The genus Dendrolagus." $21: 477-548$.

Plate 49

subject: Dendrolagus bennettianus

description and notes: chromolithograph; printed by John Bale Sons \& Danielsson; signed "F.W. Frohawk"

article: Rothschild, Lord and Guy Dollman. "The genus Dendrolagus." 21:477-548.

Plate 50

subject: Dendrolagus lumholtzi

description and notes: chromolithograph; printed by John Bale Sons \& Danielsson; signed "F.W. Frohawk"

article: Rothschild, Lord and Guy Dollman. "The genus Dendrolagus." 21:477-548. 
GARNER, Robert (1808-1890)

Volume 2 (1841)

Plate 18: "Soft parts of Lamellibranchiate Genera" subject: Psammobia florida; Nucula nucleus; Corbula striata; Pandora inaequivalvis; Solen ensis; Mactra stultorum; Cardium echinatum; Anodonta anatina; Cardium edule description and notes: engraving; plate signed Garner del., Zeitter sc.

article: Garner, Robert. "On the anatomy of the Lamellibranchiate Conchifera." 2:87-101.

Plate 19: "Soft parts of Lamellibranchiate Genera" subject: Pecten opercularis; Pecten maximus; Venerupis pullastra

description and notes: engraving; plate signed Garner del., Zeitter sc.

article: Garner, Robert. "On the anatomy of the Lamellibranchiate Conchifera." 2:87-101.

Plate 20: "Ova, Parasites, \&c. of Lamellibranchiate subject: Unio pictorum; Cyclas rivicola;

Mytilus edulis; Pecten opercularis; Anomia cepa; Pecten maximus; Nummulella?;

Distoma; Nereis phosphorescens; Anodonta; Diplotis hyalina?

description and notes: engraving; plate signed Garner del., Zeitter sc.

article: Garner, Robert. "On the anatomy of the Lamellibranchiate Conchifera." 2:87-101. 


\section{Volume $10(1879)$}

Plate 80: "Mechanism of the Odontophore in Mollusca" subject: Loligo

description and notes: hand-colored lithograph;

printed by Hanhart; plate signed P. Geddes del., J. Smit lith.

article: Geddes, Patrick. "On the mechanism of the odontophore in certain Mollusca." 10:485-491.

Plate 81: "Mechanism of the Odontophore in Mollusca" subject: Loligo; Buccinum

description and notes: hand-colored lithograph; printed by Hanhart; plate signed P. Geddes del., J. Smit lith.

article: Geddes, Patrick. "On the mechanism of the odontophore in certain Mollusca." 10:485-491.

Plate 82: "Mechanism of the Odontophore in Mollusca" subject: Buccinum

description and notes: hand-colored lithograph; printed by Hanhart; plate signed P. Geddes del., J. Smit lith.

article: Geddes, Patrick. "On the mechanism of the odontophore in certain Mollusca." 10:485-491. 


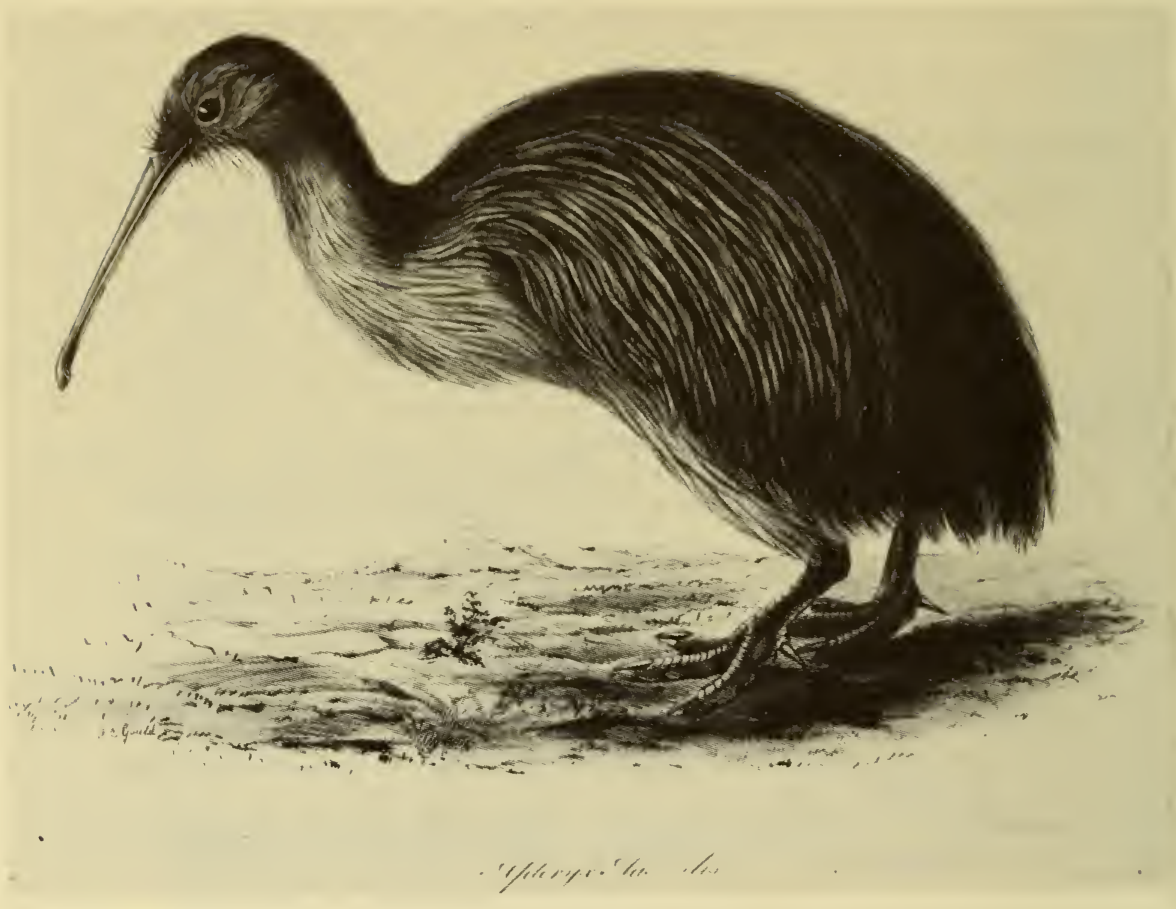

Apteryx australis

(Gould, J., 1: Flate 10)

ANiNH Library Collections 


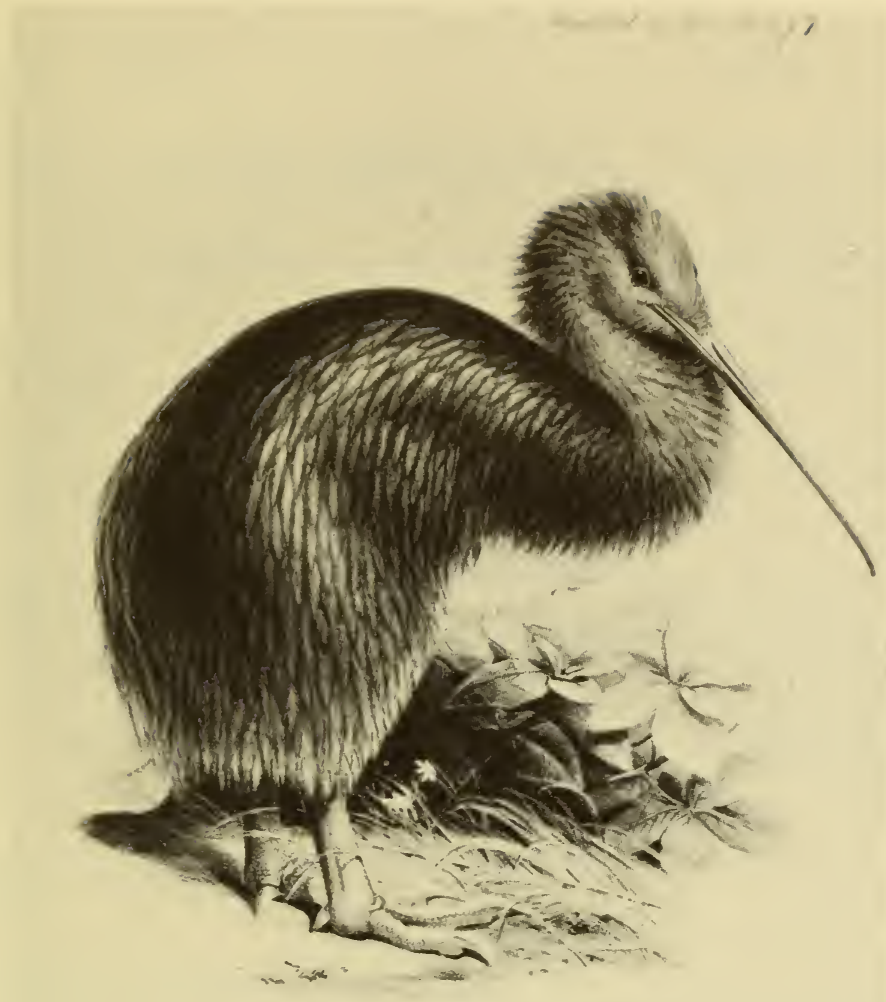

Apteryx australis

(Unsigned, 1: Plate 10)

AMNH Library Collections 


\section{GOULD, Elizabeth (1804-1841)}

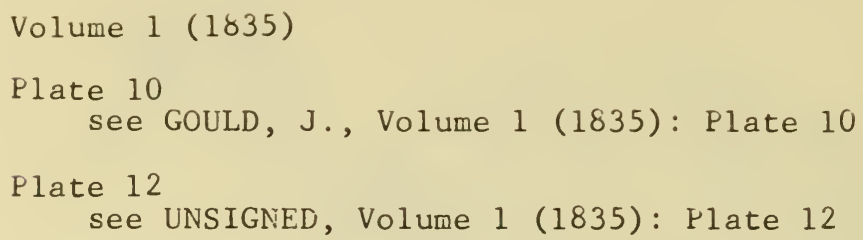


GOULD, John (1804-1881)

Volume 1 (1835)

Plate 10

subject: Apteryx australis, Shaw

description and notes: hand-colored lithograph; plate signed J. \& E. Gould del. et lith.; printed by C. Hullmandel; signed "J.E. Gould"; this plate shows the Apteryx facing left and apparently replaces the unsigned Plate 10 article: Yarrell, William. "Description, with some additional particulars, of the Apteryx australis of Shaw." 1:71-76.

Plate 12

see Unsigned, Volume 1 (1835): Plate 12

Flate 25

subject: Eurylaimus lunatus [male and female] description and notes: hand-colored lithograph; printed by $C$. Hullmandel

article: Gould, John. "Description of a new species of the genus Eurylaimus of Dr. Horsfield.' $1: 175-178$.

\section{Volume 2 (1841)}

Plate 1

subject: Coturnix erythrorhyncha

description and notes: hand-colored lithograph; printed by C. Hullmandel; plate signed J. \& E. Gould lithog.; signed "J \& E Gould"

article: Sykes, William Henry. "On the quails and

Hemipodii of India." 2:1-24.

Plate 2

subject: Coturnix argoondah

description and notes: hand-colored lithograph; printed by C. Hullmandel; plate signed J. \& E. Gould lithog.; signed "J \& E Gould"

article: Sykes, William Henry. "On the quails and Hemipodii of India." 2:1-24. 
Plate 3

subject: Coturnix pentah

description and notes: hand-colored lithograph; printed by C. Hullmandel; plate signed J. \& E. Gould lithog.; signed "J'\& E Gould"

article: Sykes, William Henry. "On the quails and Hemipodii of India." 2:1-24.

Plate 4

subject: Coturnix taigoor

description and notes: hand-colored lithograph; printed by C. Hullmandel; plate signed J. \& E. Gould lithog.; signed "J \& E Gould"

article: Sykes, William Henry. "On the quails and Hemipodii of India." 2:1-24. 
GRANT, Robert Edward (1793-1874)

\section{Volume 1 (1835)}

Plate 2

subject: Beroë pileus; Loligopsis guttata

description and notes: etching-engraving; plate signed K.E. Grant ad nat. del., Zeitter sc.; figures shown twice natural size

article: Grant, Robert E. "On the nervous system of Beroë pileus, Lam., and on the structure of its cilia." $1: 9-12$.

Plate 11

subject: Sepiola stenodactyla; Sepiola vulgaris description and notes: engraving; plate signed K.E. Grant ad nat. del., Zeitter sc.

article: Grant, Robert E. "On the anatomy of the

Sepiola vulgaris, Leach, and account of a new species (Sep. stenodactyla, Grant,) from the coast of Mauritius." 1:77-86. 
GREEN, J .

Volume 14 (1898)

Plate 3

subject: Plagioscion ternetzi

description and notes: lithograph; printed by Mintern Bros.; plate signed J. Green del. et lith.

article: Boulenger, G.A. "Cn a collection of fishes from the Rio Paraguay." 14:25-39.

Plate 4

subject: Geophagus duodecimspinosus; Euanemus nigripinnis; Oxydoras eigenmanni;

Callichthys pectoralis

description and notes: lithograph; printed by Mintern Bros.; plate signed J. Green del. et lith.

article: Boulenger, G.A. "On a collection of fishes from the Kio Paraguay." 14:25-39.

Plate 5

subject: Plecostomus ternetzi

description and notes: lithograph; printed by

Mintern Bros.; plate signed J. Green del. et lith.

article: Boulenger, G.A. "Cn a collection of fishes from the Rio Paraguay." 14:25-39.

Plate 6

subject: Chaetostomus gigas

description and notes: lithograph; printed by

Mintern Bros.; plate signed J. Green del. et lith.; two-page plate

article: Boulenger, G.A. "On a collection of fishes from the Rio Paraguay." 14:25-39.

Plate 7

subject: Loricaria labialis; Loricaria apeltogaster

description and notes: lithograph; printed by Mintern Bros.; plate signed J. Green del. et lith.

article: Boulenger, G.A. "On a collection of fishes from the Rio Paraguay." 14:25-39. 
Plate 8

subject: Loricaria parva; Tetragonopterus ternetzi; Tetragonopterus ulreyi; Anacyrtus prognathus

description and notes: lithograph; printed by Mintern Bros.; plate signed J. Green del. et lith.

article: Boulenger, G.A. "On a collection of fishes from the Rio Paraguay." 14:25-39.

Plate 39

subject: Platystoma juruense

description and notes: lithograph; printed by Mintern Bros.; plate signed J. Green del. et lith.

article: Boulenger, G.A. "On a collection of fishes from the Rio Jurua, Brazil." 14:421-428.

Plate 40

subject: Oxydoras trimaculatus; Oxydoras trachyparia; Oxydoras bachi; Oxydoras elongatus

description and notes: lithograph; printed by Mintern Bros.; plate signed J. Green del. et lith.

article: Boulenger, G.A. "On a collection of fishes from the Rio Jurua, Brazil." 14:421-428.

Plate 41

subject: Chaetostomus bachi; Acestra gladius; Cetengraulis juruensis

description and notes: lithograph; printed by Mintern Bros.; plate signed J. Green del. et lith.

article: Boulenger, G.A. "On a collection of fishes from the Rio Jurua, Brazil." 14:421-428.

Plate 42

subject: Sternarchus tamandua

description and notes: lithograph; printed by Mintern Bros.; plate signed J. Green del. et lith.

article: Boulenger, G.A. "On a collection of fishes from the Rio Jurua, Brazil." 14:421-428. 
Volume 15 (1901)

Plate 1

subject: Lates microlepis; Lamprologus

fasciatus; Lamprologus compressiceps;

Lamprologus moorii; Lamprologus modestus;

Lamprologus elongatus

description and notes: lithograph; printed by

Mintern Bros.; plate signed J. Green del. et

lith.

article: Moore, J.E.S. "Report on the collection of

fishes made by Mr. J.E.S. Moore in Lake

Tanganyika during his expedition, 1895-96."

$15: 1-30$.

Plate 2

subject: Lamprologus furcifer; Telmatochromis vittatus; Telmatochromis temporalis;

Julidochromis ornatus

description and notes: lithograph; printed by

Mintern Bros.; plate signed J. Green del. et lith.

article: Moore, J.E.S. "Keport on the collection of fishes made by Mr. J.E.S. Moore in Lake

Tanganyika during his expedition, 1895-96." $15: 1-30$.

Plate 3

subject: Paratilapia pfefferi; Paratilapia macrops; Paratilapia ventralis; Paratilapia leptosoma; Eretmodus cyanostictus

description and notes: lithograph; printed by Mintern Bros.; plate signed J. Green del. et lith.

article: Moore, J.E.S. "Report on the collection of fishes made by $\mathrm{Mr}$. J.E.S. Moore in Lake

Tanganyika during his expedition, 1895-96." $15: 1-30$.

Plate 4

subject: Paratilapia furcifer; Bathybates ferox description and notes: chromolithograph; printed by Mintern Bros.; plate signed J. Green del. et lith.

article: Moore, J.E.S. "Report on the collection of fishes made by Mr. J.E.S. Moore in Lake

Tanganyika during his expedition, 1895-96."

$15: 1-30$. 
Plate 5

subject: Tilapia labiata; Tropheus moorii

description and notes: lithograph; printed by Mintern Bros.; plate signed J. Green del. et lith.

article: Moore, J.E.S. "Report on the collection of fishes made by Mr. J.E.S. Moore in Lake

Tanganyika during his expedition, 1895-96." $15: 1-30$.

Plate 6

subject: Petrochromis polyodon; Perissodus microlepis; Haplochilus tanganicanus

description and notes: lithograph; printed by Mintern Bros.; plate signed J. Green del. et lith.

article: Moore, J.E.S. "Report on the collection of fishes made by Mr. J.E.S. Moore in Lake

Tanganyika during his expedition, 1895-96." $15: 1-30$.

Plate 7

subject: Mastacembelus moorii; Clarias iocephalus

description and notes: lithograph; printed by Mintern Bros.; plate signed J. Green del. et lith.

article: Moore, J.E.S. "Report on the collection of fishes made by Mr. J.E.S. Moore in Lake

Tanganyika during his expedition, 1895-96." $15: 1-30$.

Plate 8

subject: Synodontis multipunctatus

description and notes: chromolithograph; printed by Mintern Bros.; plate signed J. Green del. et lith.

article: Moore, J.E.S. "Report on the collection of fishes made by Mr. J.E.S. Moore in Lake Tanganyika during his expedition, 1895-96." $15: 1-30$.

Plate 14

subject: Phororhacos inflatus

description and notes: lithograph; printed by Mintern Bros.; plate signed J. Green del. et lith.

article: Andrews, C.W. "On the extinct birds of

Patagonia. I. The skull and skeleton of

Phororhacos inflatus Ameghino." 15:55-86. 
Plate 15

subject: Phororhacos inflatus

description and notes: lithograph; printed by Mintern Bros.; plate signed J. Green del. et lith.; figures shown $2 / 3$ natural size

article: Andrews, C.W. "On the extinct birds of Patagonia. I. The skull and skeleton of

Phororhacos inflatus Ameghino." 15:55-86.

Plate 16

subject: Phororhacos inflatus

description and notes: lithograph; printed by

Mintern Bros.; plate signed J. Green del. et lith.; figures shown $1 / 2$ natural size

article: Andrews, C.W. "On the extinct birds of

Patagonia. I. The skull and skeleton of

Phororhacos inflatus Ameghino." 15:55-86.

Plate 17

subject: Phororhacos inflatus

description and notes: lithograph; printed by Mintern Bros.; plate signed J. Green del. et lith.

article: Andrews, C.W. "On the extinct birds of Patagonia. I. The skull and skeleton of

Phororhacos inflatus Ameghino." 15:55-86.

Plate 18

subject: Lamprologus lemairii; Paratilapia dewindti; Grammatotria lemairii

description and notes: lithograph; printed by Mintern Bros.; plate signed J. Green del. et lith.

article: Boulenger, G.A. "Second contribution to the ichthyology of Lake Tanganyika. On the fishes obtained by the Congo Free State Expedition under Lieut. Lemaire in 1898." $15: 87-96$.

Plate 19

subject: Trematocara marginatum; Ectodus descampsi; Ectodus melanogenys; Ectodus longianalis; Xenotilapia sima; Tilapia grandoculis

description and notes: lithograph; printed by Mintern Bros.; plate signed J. Green del. et lith.

article: Boulenger, G.A: "Second contribution to the ichthyology of Lake Tanganyika. On the fishes obtained by the Congo Free State Expedition under Lieut. Lemaire in 1898." 15:87-96. 
Plate 20

subject: Tilapia dardennii; Tilapia rubropunctata; Tilapia microlepis

description and notes: chromolithograph; printed by Mintern bros.; plate signed J. Green del. et lith.

article: Boulenger, G.A. "Second contribution to the ichthyology of Lake langanyika. On the fishes obtained by the Congo Free State Expedition under Lieut. Lemaire in 1898." $15: 87-96$.

Volume 16 (1903)

Plate 12

subject: Capoëta tanganicae; Barbus platyrhinus description and notes: lithograph; printed by Mintern Bros.; plate signed J. Green del. et lith.; figures shown reduced from natural size article: Boulenger, G.A. "Third contribution to the ichthyology of Lake Tanganyika. Report on the collection of fishes made by Mr. J.E.S. Moore in Lakes Tanganyika and Kivu during his second expedition, 1899-1900." 16:137-178.

Plate 13

subject: Barbus altianalis; Barbus tropidolepis description and notes: lithograph; printed by

Mintern Bros.; plate signed J. Green del. et lith.; figures shown reduced from natural size article: Boulenger, G.A. "Thirà contribution to the ichthyology of Lake Tanganyika. Report on the collection of fishes made by Mr. J.E.S. Moore in Lakes Tanganyika and Kivu during his second expedition, 1899-1900."16:137-178.

Plate 14

subject: Barbus serrifer; Barilius moorii; Barilius tanganicae

description and notes: 1ithograph; printed by Mintern Bros.; plate signed J. Green del. et lith.; figures shown natural size and reduced from natural size

article: Boulenger, G.A. "Third contribution to the ichthyology of Lake Tanganyika. Report on the collection of fishes made by Mr. J.E.S. Moore in Lakes Tanganyika and Kivu during his second expedition, 1899-1900." 16:137-178. 
Plate 15

subject: Chrysichthys brachynema

description and notes: lithograph; printed by Mintern Bros.; plate signed J. Green del. et 1ith.; figures shown natural size and reduced from natural size

article: Boulenger, G.A. "Third contribution to the ichthyology of Lake Tanganyika. Report on the collection of fishes made by Mr. J.E.S. Moore in Lakes Tanganyika and Kivu during his second expedition, 1899-1900." 16:137-178.

Plate 16

subject: Synodontis granulosus

description and notes: lithograph; printed by Mintern Bros.; plate signed J. Green del. et lith.

article: Boulenger, G.A. "Third contribution to the ichthyology of Lake Tanganyika. Report on the collection of fishes made by Mr. J.E.S. Moore in Lakes Tanganyika and Kivu during his second expedition, 1899-1900." 16:137-178.

Plate 17

subject: Paratilapia stenosoma; Bathybates fasciatus

description and notes: 1ithograph; printed by Mintern Bros.; plate signed J. Green del. et lith.; figures shown reduced from natural size article: Boulenger, G.A. "Third contribution to the ichthyology of Lake Tanganyika. Report on the collection of fishes made by Mr. J.E.S. Moore in Lakes Tanganyika and Kivu during his second expedition, 1899-1900." 16:137-178.

Plate 18

subject: Paratilapia vittata; Xenotilapia

ornatipinnis; Trematocara unimaculatum;

Tilapia pleurotaenia

description and notes: lithograph; printed by Mintern Bros.; plate signed J. Green del. et lith.

article: Boulenger, G.A. "Third contribution to the ichthyology of Lake Tanganyika. Report on the collection of fishes made by Mr. J.E.S. Moore in Lakes Tanganyika and Kivu during his second expedition, 1899-1900." 16:137-178. 
Plate 19

subject: Paratilapia nigripinnis; Paratilapia aurita; Paratilapia calliura; Ectodus longianalis; Tilapia boops; Tilapia trematocephala

description and notes: lithograph; printed by Mintern Bros.; plate signed J. Green del. et lith.

article: boulenger, G.A. "Third contribution to the ichthyology of Lake Tanganyika. Report on the collection of fishes made by Mr. J.E.S. Moore in Lakes Tanganyika and Kivu during his second expedition, 1899-1900." 16:137-178.

Plate 20

subject: Gephyrochromis moorii; Asprotilapia

leptura; Mastacembelus frenatus;

Mastacembelus taeniatus

description and notes: lithograph; printed by Mintern Bros.; plate signed J. Green del. et lith.

article: Boulenger, G.A. "Third contribution to the ichthyology of Lake Tanganyika. Report on the collection of fishes made by $\mathrm{Mr}$. J.E.S. Moore in Lakes Tanganyika and Kivu during his second expedition, 1899-1900." 16:137-178.

Volume 17 (1903-1906)

Plate 9

subject: Plecostomus festae; Plecostomus borellii; Plecostomus cordovae

description and notes: lithograph; printed by Mintern Bros.; plate signed J. Green del. et lith.

article: Regan, C. Tate. "A monograph of the fishes of the family Loricariidae." 17:191-350.

Plate 10

subject: Plecostomus garmani; Plecostomus wuchereri

description and notes: lithograph; printed by Mintern Bros.; plate signed J. Green del. et lith.

article: Regan, C. Tate. "A monograph of the fishes of the family Loricariidae." 17:191-350. 
Plate 11

subject: Plecostomus latirostris; Ancistrus annectens

description and notes: lithograph; printed by Mintern Bros.; plate signed J. Green del. et lith.

article: Regan, C. Tate. "A monograph of the fishes of the family Loricariidae." 17:191-350.

Plate 12

subject: Ancistrus oligospilus; Ancistrus

setosus; Ancistrus guentheri; Ancistrus platycephalus

description and notes: lithograph; printed by Mintern Bros.; plate signed J. Green del. et lith.

article: Regan, C. Tate. "A monograph of the fishes of the family Loricariidae." 17:191-350.

Plate 13

subject: Chaetostomus marginatus; Chaetostomus anomalus; Chaetostomus brevis

description and notes: lithograph; printed by Mintern Bros.; plate signed J. Green del. et lith.

article: Kegan, C. Tate. "A monograph of the fishes of the family Loricariidae." 17:191-350.

Plate 14

subject: Chaetostomus marcapatae; Chaetostomus thomsoni; Chaetostomus microps; Chaetostomus maculatus; Xenocara occidentalis [male and female]; Xenocara montana; Xenocara chagresi [male and female]

description and notes: lithograph; printed by Mintern Bros.; plate signed J. Green del. et lith.

article: Regan, C. Tate. "A monograph of the fishes of the family Loricariidae." 17:191-350.

Plate 15

subject: Xenocara latifrons; Hypoptopoma guentheri; Otocinclus vittatus; Loricaria microlepidogaster; Loricaria jubata [male and female]

description and notes: lithograph; printed by Mintern Bros.; plate signed J. Green del. et lith.

article: Regan, C. Tate. "A monograph of the fishes of the family Loricariidae." 17:191-350. 
Plate 16

subject: Loricaria latirostris [male and female]; Loricaria nigricauda

description and notes: lithograph; printed by Mintern Bros.; plate signed J. Green del. et lith.

article: Regan, C. Tate. "A monograph of the $f$ ishes of the family Loricariidae." 17:191-350.

Plate 17

subject: Loricaria punctata; Loricaria simillima; Loricaria macrops

description and notes: lithograph; printed by. Mintern Bros.; plate signed J. Green del. et lith.

article: Regan, C. Tate. "A monograph of the fishes of the family Loricariidae." 17:191-350.

Plate 18

subject: Oxyloricaria guentheri; Oxyloricaria frenata

description and notes: lithograph; printed by Mintern Bros.; plate signed J. Green del. et lith.

article: Regan, C. Tate. "A monograph of the fishes of the family Loricariidae." 17:191-350.

Plate 19

subject: Oxyloricaria robusta; Oxyloricaria lyra description and notes: lithograph; printed by Mintern Bros.; plate signed J. Green del. et lith.

article: Regan, C. Tate. "A monograph of the fishes of the family Loricariidae." 17:191-350.

Plate 20

subject: Loricaria laticeps; Farlowella gladiola; Farlowella gracilis

description and notes: lithograph; printed by Mintern Bros.; plate signed J. Green del. et lith.

article: Regan, C. Tate. "A monograph of the fishes of the family Loricariidae." 17:191-350.

Plate 21

subject: Arges homodon; Arges guentheri; Arges eigenmanni; Arges orientalis; Arges chotae; Arges marmoratus; Arges festae; Arges brachycephalus; Arges simonsii

description and notes: lithograph; printed by Mintern Bros.; plate signed J. Green del. et lith.

article: Regan, C. Tate. "A monograph of the fishes of the family Loricariidae." 17:191-350. 
Plate 30

subject: Marcusenius tanganicanus; Pellonula miodon; Alestes rhodopleura

description and notes: lithograph; printed by Bale $\&$ Danielsson; plate signed J. Green del. et lith.

article: Boulenger, G.A. "Fourth contribution to the ichthyology of Lake Tanganyika. Report on the collection of fishes made by Dr. W.A. Cunnington during the Third Tanganyika Expedition, 1904-1905." 17:537-600.

Plate 31

subject: Dinotopterus cunningtoni

description and notes: 1ithograph; printed by Bale $\&$ Danielsson; plate signed J. Green del. et lith. article: Boulenger, G.A. "Fourth contribution to the ichthyology of Lake Tanganyika. Report on the collection of fishes made by Dr. W.A. Cunnington during the Third Tanganyika Expedition, 1904-1905."17:537-600.

Plate 32

subject: Neobola minuta; Chrysichthys sianenna;

Phyllonemus typus; Haplochilus pumilus

description and notes: lithograph; printed by Bale

\& Danielsson; plate signed J. Green del. et lith. article: Boulenger, G.A. "Fourth contribution to the ichthyology of Lake Tanganyika. Report on the collection of fishes made by $\mathrm{Dr}$. W.A. Cunnington during the Third Tanganyika Expedition, 1904-1905." 17:537-600.

Plate 33

subject: Auchenoglanis occidentalis var. tanganicanus

description and notes: 1ithograph; printed by Bale $\&$ Danielsson; plate signed J. Green del. et lith. article: Boulenger, G.A. Rourth contribution to the ichthyology of Lake Tanganyika. Report on the collection of fishes made by $\mathrm{Dr}$. W.A. Cunnington during the Third Tanganyika Expedition, 1904-1905." 17:537-600.

Plate 34

subject: Synodontis melanostictus

description and notes: 1ithograph; printed by Bale $\&$ Danielsson; plate signed J. Green del. et lith.; figure shown $7 / 8$ natural size

article: Boulenger, G.A. "Fourth contribution to the ichthyology of Lake Tanganyika. Report on the collection of fishes made by Dr. W.A. Cunnington during the Third Tanganyika Expedition, 1904-1905." 17:537-600. 
Plate 35

subject: Lates angustifrons; Lates microlepis;

Lamprologus multifasciatus; Lamprologus

reticulatus; Lamprologus calliurus

description and notes: lithograph; printed by Bale \& Danielsson; plate signed J. Green del. et lith.

article: Boulenger, G.A. "Fourth contribution to the ichthyology of Lake Tanganyika. Report on the collection of fishes made by Dr. W.A. Cunnington during the Third Tanganyika Expedition, 1904-1905." 17:537-600.

Plate 36

subject: Lamprologus brevianalis; Lamprologus cunningtoni; Lamprologus mondabu;

Lamprologus callipterus

description and notes: lithograph; printed by Bale \& Danielsson; plate signed J. Green del. et lith. article: Boulenger, G.A. 'Fourth contribution to the ichthyology of Lake Tanganyika. Report on the collection of fishes made by Dr. W.A. Cunnington during the Third Tanganyika Expedition, 1904-1905." 17:537-600.

Plate 37

subject: Paratilapia frontosa; Pelmatochromis polylepis

description and notes: lithograph; printed by Bale $\&$ Danielsson; plate signed J. Green del. et lith. article: Boulenger, G.A. "Fourth contribution to the ichthyology of Lake Tanganyika. Report on the collection of fishes made by Dr. W.A. Cunnington during the Third Tanganyika Expedition, 1904-1905."17:537-660.

Plate 38

subject: Bathybates minor; Haplotaxodon microlepis

description and notes: lithograph; printed by Bale $\&$ Danielsson; plate signed $\mathrm{J}$. Green del. et lith. article: Boulenger, G.A. "Fourth contribution to the ichthyology of Lake Tanganyika. Report on the collection of fishes made by Dr. W.A. Cunnington during the Third Tanganyika Expedition, 1904-1905." 17:537-600. 
Plate 39

subject: Pelmatochromis melanostigma;

Pelmatochromis pleurospilus; Pelmatochromis rhodostigma; Pelmatochromis auritus

description and notes: chromolithograph; plate signed J. Green del. et Chromo lith.; printer not identified on plate

article: Boulenger, G.A. "Fourth contribution to the ichthyology of Lake Tanganyika. Report on the collection of fishes made by Lr. W.A. Cunnington during the Third Tanganyika Expedition, 1904-1905." 17:537-600.

Plate 40

subject: Tilapia latifrons

description and notes: lithograph; printed by Bale \& Danielsson; plate signed J. Green del. et lith. article: Boulenger, G.A. Fourth contribution to the ichthyology of Lake Tanganyika. Report on the collection of fishes made by Dr. W.A. Cunnington during the Third Tanganyika Expedition, 1904-1905." 17:537-600.

Plate 41

subject: Trematocara nigrifrons; Cunningtonia longiventralis; Mastacembelus cunningtoni

description and notes: lithograph; printed by Bale \& Danielsson; plate signed J. Green del. et lith. article: Boulenger, G.A. "Fourth contribution to the ichthyology of Lake Tanganyika. Report on the collection of fishes made by Dr. W.A. Cunnington during the Third Tanganyika Expedition, 1904-1905." 17:537-600.

Volume 18 (1907-1911)

Plate 38

subject: Marcusenius castelnaui Blgr.; Clarias ngamensis Casteln.

description and notes: lithograph; plate signed J. Green del., lith. et imp.

article: Boulenger, G.A. "On a collection of fishes from the Lake Ngami Basin, Bechuanaland." $18: 399-430$. 
Plate 39

subject: Paratilapia frederici Casteln.;

Paratilapia smithii Casteln.

description and notes: lithograph; plate signed J. Green del., lith. et imp.; figures shown $7 / 8$ natural size

article: Boulenger, G.A. "On a collection of fishes from the Lake Ngami Basin, Bechuanaland." $18: 399-430$.

Plate 40

subject: Paratilapia longimanus Blgr.

description and notes: lithograph; plate signed J. Green del., lith. et imp.

article: Boulénger, G.A. "On a collection of fishes from the Lake Ngami Basin, Bechuanaland."

$18: 399-430$.

Plate 41

subject: Paratilapia thumbergi Casteln.

description and notes: lithograph; plate signed J. Green del., lith. et imp.

article: Boulenger, G.A. "On a collection of fishes from the Lake Ngami Basin, Bechuanaland." $18: 399-430$.

Plate 42

subject: Paratilapia angusticeps Blgr.

description and notes: lithograph; plate signed J. Green del., lith. et imp.

article: Boulenger, G.A. "On a collection of fishes from the Lake Ngami Basin, Bechuanaland." $18: 399-430$.

Plate 43

subject: Paratilapia gibbiceps Blgr.; Tilapia woosnami Blgr.

description and notes: lithograph; plate signed J. Green del., lith. et imp.

article: Boulenger, G.A. "On a collection of fishes from the Lake Ngami Basin, Bechuanaland." $18: 399-430$. 
Volume 19 (1909-1910)

Plate 1: "Land Shells from Ruwenzori"

subject: Limicolaria saturata; Limicolaria smithi; Achatina schweinfurthi var.; Trachycystis? ruwenzoriensis; Trochozonites leptaleus; Homorus fuscostrigatus; Homorus bicolor

description and notes: chromolithograph; plate signed J. Green del. et Chromo lith.

article: Smith, E.A. "Ruenzori Expedition reports. 4. Mollusca." 19:43-50.

Plate 8

subject: Rana nutti Blgr. [female]; Lygosoma meleagris Blgr.; Chamaeleon ellioti Gthr. [female]; Chamaeleon rudis Blgr. [male and female ]

description and notes: lithograph; plate signed J. Green del. lith. et imp.

article: Boulenger, G.A. "Ruwenzori Expedition reports. 15. Pisces, Batrachia, and Reptilia." $19: 237-252$.

Plate 9

subject: Atheris woosnami Blgr. [female]

description and notes: chromolithograph; plate signed J. Green del. et Chromo lith.

article: Boulenger, G.A. "Ruwenzori Expedition reports. 15. Pisces, Batrachia, and Reptilia." $19: 237-252$.

Volume 20 (1912-1915)

Plate 27

subject: Hyla wollastoni; Nyctimantis granti;

Spnenophryne klossi; Liophryne kampeni

description and notes: lithograph; plate signed $\mathrm{J}$. Green del. lith. et imp.

article: Boulenger, G.A. "An annotated list of the batrachians and reptiles collected by the British Ornithologists' Union Expedition and the Wollaston Expedition in Dutch New Guinea." $20: 247-274$. 
Plate 28

subject: Carettochelys insculpta; Gymnodactylus

mimikanus; Gonyocephalus auritus;

Gonyocephalus nigrigularis

description and notes: lithograph; plate signed J. Green del. lith. et imp.

article: boulenger, G.A. "An annotated 1 ist of the Batrachians and reptiles collected by the

British Ornithologists' Union Expedition and the Wollaston Expedition in Dutch New Guinea." $20: 247-274$.

Plate 29

subject: Lygosoma nototaenia; Lygosoma mimikanum; Lygosoma klossi; Lygosoma tropidolepis

description and notes: lithograph; plate signed J. Green del. lith. et imp.

article: Boulenger, G.A. "An annotated list of the Batrachians and reptiles collected by the British Ornithologists' Union Expedition and the Wollaston Expedition in Dutch New Guinea." $20: 247-274$.

Plate 30

subject: Lygosoma wollastoni; Lygosoma

oligolepis; Apistocalamus grandis;

Apistocalamus loennbergii; Micropechis

ikaheka var. fasciatus

description and notes: lithograph; plate signed J. Green del. lith. et imp.

article: Boulenger, G.A. "An annotated 1 ist of the Batrachians and reptiles collected by the British Ornithologists' Union Expedition and the Wollaston Expedition in Dutch New Guinea." $20: 247-274$.

Plate 31

subject: Rhadinocentris ornatus; Centratherina crassispinosa; Anisocentrus rubrostriatus; Chilatherina fasciata; Rhombosoma novae-guineae

description and notes: lithograph; plate signed J. Green del. lith. et imp.

article: Regan, C. Tate. "Report on the freshwater fishes collected by the British Ornithologists' Union Expedition and the Wollaston Expedition in Dutch New Guinea." 20:275-286.

Plate 33

see Robson, 20: Plate 33 
Volume 9 (1877)

Plate 1: "Dentition"

subject: Elephas mnaidriensis; Elephas melitensis

description and notes: lithograph; printed by Mintern Bros.; figures shown natural size

article: Adams, A. Leith. "On the dentition and osteology of the Maltese fossil elephants, being a description of remains discovered by the author in Malta between the years 1860 and 1866." 9:1-124.

Plate 2: "Dentition"

subject: Elephas melitensis; Elephas mnaidriensis

description and notes: lithograph; printed by Mintern Bros.; figures shown natural size article: Adams, A. Leith. "On the dentition and osteology of the Maltese fossil elephants, being a description of remains discovered by the author in Malta between the years 1860 and 1866." 9:1-124.

Plate 3: "Dentition"

subject: Elephas mnaidriensis

description and notes: lithograph; printed by Mintern Bros.; figures shown natural size article: Adams, A. Leith. "On the dentition and osteology of the Maltese fossil elephants, being a description of remains discovered by the author in Malta between the years 1860 and 1866." 9:1-124.

Plate 4: "Dentition"

subject: Elephas melitensis; Elephas mnaidriensis

description and notes: lithograph; printed by Mintern Bros.; figures shown natural size article: Adams, A. Leith. "On the dentition and osteology of the Maltese fossil elephants, being a description of remains discovered by the author in Malta between the years 1860 and 1866." 9:1-124. 
Plate 5: "Dentition"

subject: Elephas melitensis

description and notes: lithograph; printed by

Mintern Bros.; figures shown natural size

article: Adams, A. Leith. "On the dentition and

osteology of the lialtese fossil elephants, being

a description of remains discovered by the

author in llalta between the years 1860 and 1866." $9: 1-124$.

Plate 8: "Dentition"

subject: Elephas mnaidriensis

description and notes: lithograph; printed by Mintern Bros.; figures shown $1 / 2$ natural size

article: Adams, A. Leith. "On the dentition and

osteology of the Maltese fossil elephants, being

a description of remains discovered by the author in Malta between the years 1860 and 1866." $9: 1-124$.

Plate 9: "Dentition, Scapula, Ribs, Vertebra" subject: Elephas melitensis

description and notes: lithograph; printed by Mintern Bros.; figures shown natural size article: Adams, A. Leith. "On the dentition and osteology of the Maltese fossil elephants, being a description of remains discovered by the author in Malta between the years 1860 and 1866." $9: 1-124$.

Flate 11: "Tusks, Molar, Humerus, Scapula, Vertebra, Femur"

subject: Elephas mnaidriensis; Elephas melitensis; Hippopotamus (?)

description and notes: lithograph; printed by Mintern Bros.; figures shown $1 / 3$ natural size article: Adams, A. Leith. "On the dentition and osteology of the Maltese fossil elephants, being a description of remains discovered by the author in Malta between the years 1860 and 1866." 9:1-124.

Plate 12: "Humerus Scapula" subject: Elephas melitensis

description and notes: lithograph; printed by Mintern Bros.; figures shown natural size article: Adams, A. Leith. "On the dentition and osteology of the Maltese fossil eleptants, being a description of remains discovered by the author in Malta between the years 1860 and $1866 . " 9: 1-124$. 
Plate 13: "Atlas Radius Ulna"

subject: Elephas melitensis

description and notes: lithograph; printed by

Mintern Bros.; figures shown natural size

article: Adams, A. Leith. "On the dentition and

osteology of the Maltese fossil elephants, being a description of remains discovered by the author in Malta between the years 1860 and $1866 . "$." $9: 1-124$.

Plate 14: "Femur"

subject: Elephas mnaidriensis; Elephas melitensis

description and notes: lithograph; printed by Mintern Bros.; figures shown $1 / 2$ natural size article: Adams, A. Leith. "On the dentition and osteology of the Maltese fossil elephants, being a description of remains discovered by the author in Malta between the years 1860 and 1866." $9: 1-124$.

Plate 15: "Stylo-Hyoid, Pelvis, Patella, Tibia, Fibula" subject: Elephas mnaidriensis; Elephas melitens is

description and notes: lithograph; printed by Mintern Bros.; figures shown $1 / 2$ natural size article: Adams, A. Leith. "On the dentition and osteology of the Maltese fossil elephants, being a description of remains discovered by the author in Malta between the years 1860 and 1866 ." $9: 1-124$.

Plate 21: "Upper Extremity, Vertebra, Fib, Femur, Tibia" subject: Elephas melitensis; Elephas
mnaidriensis

description and notes: lithograph; printed by Mintern Bros.; figures shown natural size article: Adams, A. Leith. "On the dentition and osteology of the Maltese fossil elephants, being a description of remains discovered by the author in Malta between the years 1860 and 1866." $9: 1-124$. 
Volume 10 (1879)

Plate 32

subject: Dinornis maximus

description and notes: lithograph; printed by Mintern Bros.; folded plate

article: Owen, [Professor]. "On Dinornis (Part XXI.): containing a restoration of the skeleton of Dinornis maximus, Owen. With an appendix, on additional evidence of the genus Dromornis in Australia." 10:147-188. 
Volume 14 (1898)

Plate 35: "Skulls and Teeth of Philippine Mammals" subject: Harpyionycteris whiteheadi; Crunomys fallax; Chrotomys whiteheadi; Rhynchomys soricoides; Celaenomys silaceus

description and notes: collotype; printed by Morgan $\&$ Kidd

article: Thomas, Oldfield. "Cn the mammals obtained by $\mathrm{Mr}$. John Whitehead during his recent expedition to the Philippines." 14:377-412.

Plate 36: "Skulls and Teeth of Philippine Mammals" subject: Lenomys meyeri; Crateromys schadenbergi; Mus luzonicus; Carpomys melanurus; Carpomys phaeurus; Batomys granti description and notes: collotype; printed by Morgan $\&$ Kidd

article: Thomas, Oldfield. "On the mammals obtained by $\mathrm{Mr}$. John Whitehead during his recent expedition to the Philippines." 14:377-412.

Volume 15 (1901)

Plate 42: "Structure of the Palaeognathae" subject: Rhea americana; Dromaeus novae-hollandiae; Struthio molybdophanes; Apteryx australis

description and notes: photoprint; printed by Bale $\&$ Danielsson

article: Rothschild, Walter and W.P. Pycraft. "A monograph of the genus Casuarius. With a dissertation on the morphology and phylogeny of the Palaeognathae (Ratitae and Crypturi) and Neognathae (Carinatae)." 15:109-290. 
Plate 43: "Structure of the Palaeognathae"

subject: Apteryx mante1li; Apteryx australis mante11i; Emeus; Dromaeus novae-hollandiae; Rhea americana; Bubo maximus; Dromaeus irroratus?; Apteryx oweni

description and notes: photoprint; printed by Bale $\&$ Danielsson

article: Rothschild, Walter and W.P. Pycraft. "A monograph of the genus Casuarius. With a dissertation on the morphology and phylogeny of the Palaeognathae (Ratitae and Crypturi) and Neognathae (Carinatae)." 15:10y-290.

Plate 44: "Structure of the Palaeognathae" subject: Dromaeus ater; Dromaeus novae-hollandiae; Casuarius unappendiculatus; Casuarius sclateri

description and notes: photoprint; printed by Bale $\&$ Danielsson

article: Kothschild, Walter and W.P. Pycraft. "A monograph of the genus Casuarius. With a dissertation on the morphology and phylogeny of the Palaeognathae (Ratitae and Crypturi) and Neognathae (Carinatae)." 15:109-290.

Plate 45: "Structure of the Palaeognathae" subject: Rhea americana; Calodromas elegans;

Dromaeus novae-hollandiae; Casuarius casuarius; Apteryx mantelii; Struthio camelus; Casuarius unappendiculatus;

Casuarius australis

description and notes: photoprint; printed by Bale $\&$ Danielsson

article: Rothschild, Walter and W.P. Pycraft. "A monograph of the genus Casuarius. With a dissertation on the morphology and phylogeny of the Palaeognathae (Ratitae and Crypturi) and Neognathae (Carinatae)." 15:109-290. 
Volume 16 (1903)

Plate 26: "Myology of the Tongue of Parrots" subject: Eos riciniata; Stringops habroptilus; Psittacus erithacus; Cacatua galerita; Platycercus eximius; Ptistes erythropterus; Palaeornis torquata; Pezoporus formosus; Conurus jendaya; Paeocephalus rüppelli; Platycercus eximius

description and notes: photoprint, hand-colored; printed by Bale \& Danielsson; plate signed $H$. Grönvold del.

article: Mudge, Geo. P. "On the myology of the tongue of parrots, with a classification of the order, based upon the structure of the tongue." $16: 211-278$.

Plate 27: "Myology of the Tongue of Parrots" subject: Chrysotis ochrocephala; Cacatua galerita; Chrysotis panamensis; Psittacus erithacus; Psittacus erithacus; Coracopsis vasa; Stringops habroptilus; Pyrrhura leucotis; Ara macao; Lorius domicella; Nestor notabilis; Loriculus galgulus description and notes: photoprint, hand-colored; printed by Bale \& Danielsson; plate signed H. Grönvold del.

article: Mudge, Geo. P. "On the myology of the tongue of parrots, with a classification of the order, based upon the structure of the tongue." $16: 211-278$.

Plate 28: "Myology of the Tongue of Parrots" subject: Ara ararauna; Cacatua galerita; Stringops habroptilus; Ara macao; Chrysotis ochrocephala; Psittacus erithacus; Conurus cactorum; Coracopsis vasa; Palaeornis torquata; Brotogerys pyrrhopterus; Psittinus incertus; Ptistes erythropterus; Conurus jendaya

description and notes: photoprint, hand-colored; printed by Bale \& Danielsson; plate signed H. Grönvold del.

article: Mudge, Geo. P. "On the myology of the tongue of parrots, with a classification of the order, based upon the structure of the tongue." $16: 211-278$. 
Plate 29: "Myology of the Tongue of Parrots" subject: Lorius domicella; Lorius

flavo-palliatus; Eos riciniata; Pyrrhura

leucotis; Psittacula passerina; Loriculus galgulus; Pionopsittacus pileatus;

Platycercus eximius; Bolborhynchus

Iineolatus; Nestor notabilis; Pezoporus

formosus; Nasiterna pusio; Eclectus

pectoralis; Lorius domicella; Loriculus galgulus

description and notes: photoprint, hand-colored; printed by Bale \& Danielsson; plate signed $\mathrm{H}$. Grönvold del.

article: Mudge, Geo. P. "On the myology of the tongue of parrots, with a classification of the order, based upon the structure of the tongue." $16: 211-278$.

Plate 31: "The Okapi (Okapia johnstoni)" subject: Okapia johnstoni

description and notes: photoengraving; printed by Swan Electric Engraving Co.; plate signed $\mathrm{H}$. Grönvold del.

article: Lankester, E. Ray. "On Okapia, a new genus of Giraffidae, from Central Africa." $16: 279-314$.

Plate 32: "The Okapi (Okapia johnstoni)"

subject: Okapia johnstoni

description and notes: photoengraving; printed by

Swan Electric Engraving Co.; plate signed $\mathrm{H}$.

Grönvold del.

article: Lankester, E. Ray. "On Okapia, a new genus of Giraffidae, from Central Africa." $16: 279-314$.

Volume 19 (1909-1910)

Plate 10

subject: Malimbus fagani Grant [male];

Spermospiza poliogenys Grant [female];

Pyromelana crassirostris Grant [male]; Neisna nyansae Neumann [male]

description and notes: chromolithograph; printer not noted on plate; plate signed J. Green Chromo lith.; signed "H. Grönvold"

article: Ogilvie-Grant, W.R. "Ruwenzori Expedition

Reports. 16. Aves."19:253-453. 
Plate 11

subject: Nesocharis ansorgei Hartert [male and female]; Cryptospiza salvadorii Reichenow [male]; Pytelia belli Grant [male]

description and notes: chromolithograph; printer not noted on plate; plate signed J. Green Chromo lith.; signed "H. Grönvold"

article: Ogilvie-Grant, W.R. "Ruwenzori Expedition Reports.16. Aves."'19:253-453.

Plate 12

subject: Nectarinia dartmouthi Grant [male and female]; Cryptolopha alpina Grant [male]

description and notes: chromolithograph; printer not noted on plate; plate signed J. Green Chromo lith.; signed "H. Grönvold"

article: Ogilvie-Grant, W.R. "Ruwenzori Expedition Reports.16. Aves."19:253-453.

Plate 13

subject: Pholidornis denti Grant [male]; Anthoscopus roccatii Salvadori [male]; Sylviella denti Grant [male]; Anthus leggei Grant [male]

description and notes: chromolithograph; printer not noted on plate; plate signed J. Green Chromo lith.; signed "H. Grönvold"

article: Ogilvie-Grant, W.R. "Ruwenzori Expedition Reports.16. Aves."19:253-453.

Plate 14

subject: Erythrocercus congicus Grant [male];

Apalis affinis Grant [male]; Apalis denti Grant [female]; Apalis ruwenzorii Jackson [male]

description and notes: chromolithograph; printer not noted on plate; plate signed J. Green Chromo lith.; signed "H. Grönvold"

article: Ogilvie-Grant, W.R. "Ruwenzori Expedition Reports.16. Aves."19:253-453.

Plate 15

subject: Alethe woosnami Grant [male]; Alethe carruthersi Grant [male]

description and notes: chromolithograph; printer not noted on plate; plate signed J. Green Chromo lith.; signed "H. Grönvold"

article: Ogilvie-Grant, W.R. "Ruwenzori Expedition Reports.16. Aves."19:253-453. 
Plate 16

subject: Bradypterus alfredi Hartlaub. [female]; Cossypha archeri Sharpe [male]; Bradypterus barakae Sharpe [male]

description and notes: chromolithograph; printer not noted on plate; plate signed J. Green Chromo lith.; signed "H. Grönvold"

article: Ogilvie-Grant, W.K. "Ruwenzori Expedition Reports. 16. Aves."' 19:253-453.

Plate 17

subject: Phyllanthus czarnikowi Grant [male]; Bleda woosnami Grant [male]

description and notes: chromolithograph; printer not noted on plate; plate signed J. Green Chromo lith.; signed "H. Grönvold"; figures shown $3 / 4$ natural size

article: Ogilvie-Grant, W.R. "Ruwenzori Expedition Reports. 16. Aves."'19:253-453.

Plate 18

subject: Trochocercus bedfordi Grant [male];

Batis diops Jackson [male]; Chloropeta

gracilirostris Grant [male]; Tarsiger ruwenzori Grant [male]

description and notes: chromolithograph; printer not noted on plate; plate signed J. Green Chromo lith.; signed "H. Grönvold"

article: Ogilvie-Grant, W.R. "Ru'wenzori Expedition Reports.16. Aves."'19:253-453.

Plate 19: "Figures of Eggs of Birds met with on

Ruwenzori"

subject: Emberiza flaviventris; Hyphantornis jacksoni; Geocichla piaggae; Hyphantornis jacksoni; Emberiza flaviventris; Sylviella barakae; Cinnyris cupreus; Pternistes cranchi; Nectarinia kilimensis; Camaroptera griseoviridis; Cisticola erythrops;

Cryptolopha alpina; Terpsiphone suahelica;

Cisticola chubbi; Amblyospiza melanonota;

Oedicnemus vermiculatus; Sitagra aliena;

Tarsiger ruwenzori; Xenocichla kikuyuensis;

Telephonus erythropterus; Laniarius erythrogaster; Caprimulgus fossei

description and notes: chromolithograph; printer not noted on plate; plate signed H. Grönvold pinxt., J. Green Chromo lith.

article: Ogilvie-Grant, W.R. "Ruwenzori Expedition Reports. 16. Aves."'19:253-453. 


$$
\text { HAMILTON, A. }
$$

\section{Volume $13(1895)$}

Plate 62: "Outlines of Crania of Dinornithidae, Parts of Skull of Various Ratitae"

subject: Dinornis torosus Hutt; Anomolopteryx didiformis OW.; Pachyornis elephantopus; Pachyornis sp. alpha; Mesopteryx casuarina Ow.; Mesopteryx sp. alpha; Mesopteryx sp. beta; Mesopteryx sp. lambda; Emeus sp. alpha; Emeus sp. beta; Emeus crassus Ow.; Emeus sp. lambda; Struthio; Rhea; Dromaeus; Casuarius; Apteryx; Dinornis description and notes: hand-colored lithograph; printed by West, Newnian; plate signed A. Hamilton \& T.J.P. delt., M.P. Harker 1ith. article: Parker, T. Jeffrey. "On the cranial osteology, classification, and phylogeny of the Dinornithidae." 13:373-431. 
HAWKINS, W.

\section{Volume 3 (1849)}

Plate 10

subject: Ostracion spilogaster, Rich.; Ostracion ornatus, Gray

description and notes: hand-colored engraving;

plate signed W. Hawkins \& W. Mitchell del., J.

Basire sc.; figures shown natural size

article: Richardson, John. "(Part 2.) Description of Australian fish." 3:133-185.

Plate 11

see Mitchel1, W., 3: Plate 11 
HICKSOI, A.W.

Volume 13 (1895)

Plate 49

subject: Clavularia viridis

description and notes: chromolithograph; printed by West, Newman; plate signed A.W. Hickson del., M.P. Parker chromo.

article: Hickson, Sydney J. "A revision of the genera of the alcyonaria stolonifera, with a description of one new genus and several new species." 13:325-347. 
HICKSON, Sydney John (1859-1940)

\section{Volume 13 (1895)}

Plate 50: "Structure of Stereosoma and Clavularia" subject: Stereosoma celebense; Clavularia australiensis var. A; Clavularia australiensis var. B; Clavularia ramosa; Clavularia flava; Clavularia garciae; Clavularia viridis

description and notes: lithograph; printed by West, Newman; plate signed S.J.H. del., M.Y. Parker lith.

article: Hickson, Sydney J. "A revision of the genera of the alcyonaria stolonifera, with a description of one new genus and several new species." 13:325-347. 
HIGHLEY, Percy (1856-1929)

Volume 13 (1895)

Plate 11

see Berjeau, 13: Plate 11

Plate 12

see Berjeau, 13: Plate 12

Plate 19

see Berjeau, 13: Plate 19 


\section{HILLS}

volume 1 (1835)

Plate 1

subject: Antilope mhorr

description and notes: hand-colored engraving-etching; plate signed Hills del., Zeitter sc.

article: Bennett, E.T. "On the M'horr antelope." $1: 1-8$. 
HILLS, R.

Volume 3 (1849)

Plate 1

subject: Camelopardalis giraffa

description and notes: hand-colored engraving;

plate signed Drawn by R. Hills Esqr., Engraved by J. Zeitter.

article: Owen, Richard. "Notes on the birth of the giraffe at the Zoological Society's Gardens, and description of the foetal membranes and of some of the natural and morbid appearances observed

in the dissection of the young animal." 3:21-28. 


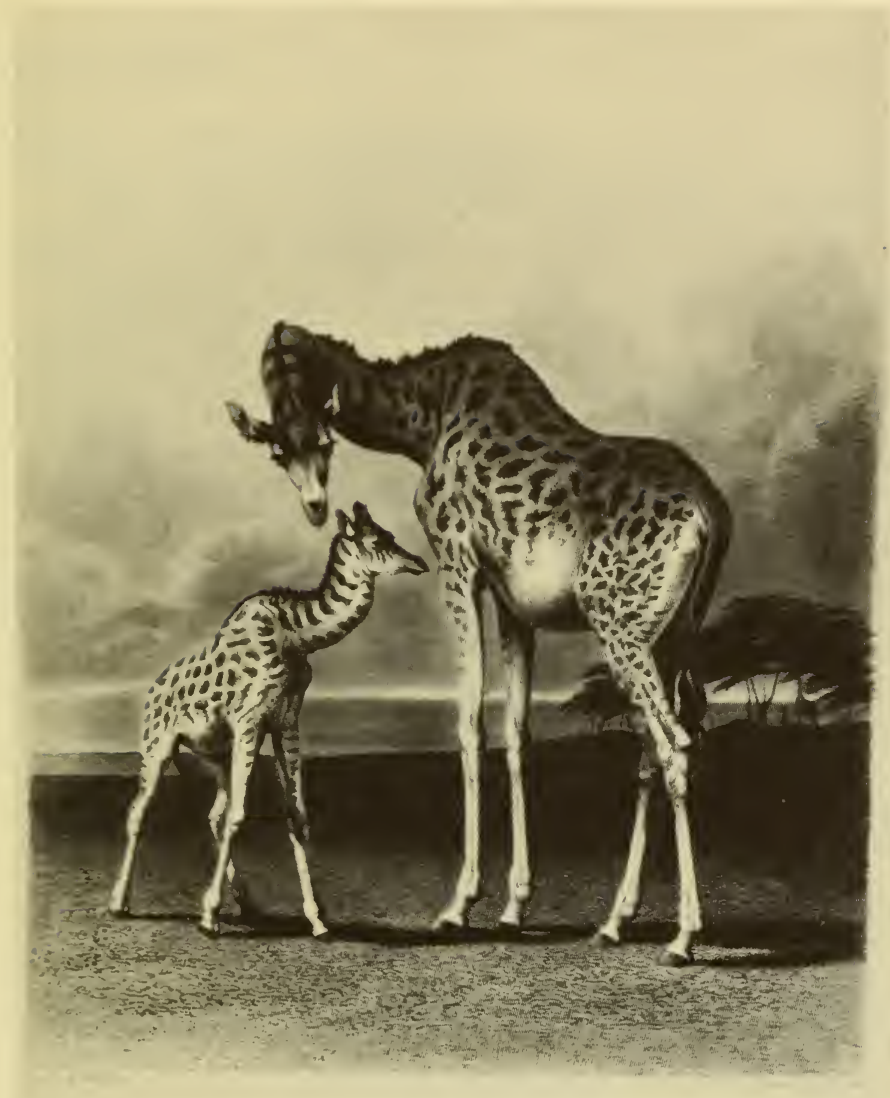

Camelopardalis giraffa (Hills, 3: Plate 1)

AMNH Library Collections 

HORNE, Charles

Volume 7 (1872)

Plate 19: "Indian Hymenoptera" subject: Megachile fasciculata [male and female]; Megachile lanata [female and male]; Megachile disjuncta [female]

description and notes: lithograph, a few figures hand-colored; printed by $W$. West; plate signed C. Horne del., E. Smith lith

article: Horne, Charles and Frederick Smith. "Notes on the habits of some hymenopterous insects from the north-west provinces of India. With an appendix, containing descriptions cf some new species of Apidae and Vespidae collected by Mr. Horne." 7:161-196.

Flate 20: "Indian Hymenoptera" subject: Rhynchium nitidulum [female]; Eumenes conica [female]; Eumenes mainpuriensis [female]; Eumenes edwardsii [female]; Rhynchium carnaticum [female]; Eumenes esuriens [female]; Odynerus punctum [female]; Icaria variegata [female]

description and notes: lithograph, a few figures hand-colored; printed by W. West; plate signed C. Horne del., E. Smith lith article: Horne, Charles and Frederick Smith. "Notes on the habits of some hymenopterous insects from the north-west provinces of India. With an appendix, containing descriptions of some new species of Apidae and Vespidae collected by Mr. Horne." 7:161-196. 
Plate 21: "Indian Hymenoptera"

subject: Parapison rufipes [female]; Pelopoeus bengalensis [pupa cases]; Trypoxylon rejector; Pisonitus rugosus [female]; Pelopoeus madraspatanus; Pterochilus pulchellus [female]; Vespa vivax [female]; Vespa flaviceps [female]; Vespa structor [female]; Bombus atrocinctus [malej; Pelopoeus bilineatus [female]

description and notes: lithograph, a few figures hand-colored; printed by $W$. West; plate signed C. Horne del., E. Smith lith

article: Horne, Charles and Frederick Smith. "Notes on the habits of some hymenopterous insects from the north-west provinces of India. With an appendix, containing descriptions of some new species of Apidae and Vespidae collected by Mr. Horne." 7:161-196.

Plate 22: "Indian Hymenoptera"

subject: Xylocopa chloroptera [female];

Emanadia sp.?; Apis floralis [female and male]; Apis dorsata; Galleria mellolella description and notes: lithograph, a few figures hand-colored; printed by W. West; plate signed C. Horne del., E. Smith lith

article: Horne, Charles and Frederick Smith. "Notes on the habits of some hymenopterous insects from the north-west provinces of India. With an appendix, containing descriptions of some new species of Apidae and Vespidae collected by Mr. Horne." 7:161-196. 


\section{Volume $11(1885)$}

Plate 21: "Female Organs of Indian Elephant" subject: Elephas indicus

description and notes: lithograph; printed by Hanhart; plate signed W.M. Howe del., J. Smit lith.; figure shown $1 / 2$ natural size article: Watson, M. "On the anatomy of the female organs of the Proboscidea." 11:111-130.

Plate 22: "Female Organs of Indian Elephant" subject: Elephas indicus

description and notes: lithograph; printed by Hanhart; plate signed W.M. Rowe [sic] del., J. Smit lith.

article: Watson, M. "On the anatomy of the female organs of the Proboscidea." 11:111-130. 


\section{JENNENS, John [fl. 1860s ]}

Volume 4 (1862)

Plate 54: "The Dodo (From a Picture by Roland Savery)" subject: Didus ineptus

description and notes: hand-colored lithograph; printed by Stannard \& Dixon; plate signed John Jennens, del. et lith.

article: Broderip, W.J. "Additional evidence relative to the dodo." $4: 183-186$.

Plate 56: "Kaup's Strigidae"

subject: Glaucidium ferrugineum; Athene;

Surnia passerina; Surnia ulula; Ieraglaux

connivens; Otus brachyotus

description and notes: lithograph; printed by

Stannard \& Dixon; plate signed John Jennens, lith.

article: Kaup, J.J. "Monograph of the Strigidae." 4:201-260.

Plate 57: "Kaup's Strigidae"

subject: Otus vulgaris; Bubo africanus; Bubo

ketupa; Strix flammea; Syrnium aluco

description and notes: lithograph; printed by

Stannard \& Dixon; plate signed John Jennens, lith.

article: Kaup, J.J. "Monograph of the Strigidae."

4:20i-260. 


$$
\text { JONES, Rymer }
$$

\section{Volume 1 (1835)}

Plate $j 2$

subject: Ornithorhynchus paradoxus

description and notes: engraving; plate signed Rymer Jones Esq. del., Zeitter sc.

article: Owen, Richard. "On the young of the

Ornithorhynchus paradoxus, Blum." $1: 221-228$. 


\section{JONES, Thomas Rymer (1810-1880)}

\section{Volume 1 (1835)}

\section{Plate 20}

subject: Felis jubata; Felis domestica

description and notes: lithograph; plate signed

T.R. Jones del., G. Scharf lithog.; printed by

C. Hullmandel; figures show brains only

article: Owen, Richard. "On the anatomy of the

cheetah, Felis jubata, Schreb."1:129-136. 
JURY, Julius (1821-1870)

\section{Volume 4 (1862)}

\section{Plate 67 a}

subject: Struthio camelus [male]

description and notes: hand-colored 1ithograph; printed by 1 . \& N. Hanhart; plate signed J. Jury ad. nat. lith.; signed "Jury"

article: Sclater, Philip Lutley. "On the struthious birds living in the Society's Menagerie." 4:353-364.

Plate 68

subject: Rhea americana [female]

description and notes: hand-colored lithograph;

printed by M. \& N. Hanhart; plate signed J. Jury ad. nat. lith.

article: Sclater, Philip Lutley. "On the struthious birds living in the Society's Menagerie." 4:353-364.

Plate 69

subject: Rhea macrorhyncha [male]

description and notes: hand-colored lithograph; printed by $M$. \& N. Hanhart; plate signed J. Jury ad. nat. lith.

article: Sclater, Philip Lutley. "On the struthious birds living in the Society's Menagerie." 4:353-364.

Plate 70

subject: Rhea darwinii [male]

description and notes: hand-colored lithograph; printed by $M . \& N$. Hanhart; plate signed J. Jury ad. nat. lith.

article: Sclater, Philip Lutley. "On the struthious birds living in the Society's Menagerie." 4:353-364. 


\section{Plate 71}

subject: Casuarius galeatus [male]

description and notes: hand-colored lithograph; printed by $M$. \& N. Hanhart; plate signed J. Jury ad. nat. lith.; signed "J. Jury"

article: Sclater, Philip Lutley. "On the struthious birds living in the Society's Menagerie." 4:353-364.

\section{Plate 72}

subject: Casuarius bennettii [malej]

description and notes: hand-colored lithograph; printed by $M . \& N$. Hanhart; plate signed J. Jury ad. nat. lith.; signed "J. Jury"

article: Sclater, Philip Lutley. "On the struthious birds living in the Society's Menagerie." 4:353-364.

\section{Plate 73}

subject: Casuarius bicarunculatus [juvenile]

description and notes: hand-colored lithograph;

printed by M. \& N. Hanhart; plate signed J. Jury ad. nat. lith.

article: Sclater, Philip Lutley. "On the struthious birds living in the Society's Menagerie." 4:353-364.

Plate 74

subject: Casuarius uniappendiculatus

description and notes: hand-colored lithograph;

printed by M. \& N. Hanhart; plate signed J. Jury ad. nat. lith.

article: Sclater, Philip Lutley. "On the struthious birds living in the Society's Menagerie." 4:353-364.

Plate 75

subject: Dromaeus novae-hollandiae

description and notes: hand-colored lithograph; printed by M. \& N. Hanhart; plate signed J. Jury ad. nat. 1ith.

article: Sclater, Philip Lutley. "On the struthious birds living in the Society's Menagerie." 4:353-364.

Plate 76

subject: Dromaeus irroratus

description and notes: hand-colored lithograph; printed by M. \& N. Hanhart; plate signed J. Jury ad. nat. lith.

article: Sclater, Philip Lutley. "On the struthious birds living in the Society's Menagerie." 4:353-364. 


$$
\text { JURY, Julius }
$$

Volume 6 (1869)

\section{Plate 79}

subject: Heros affinis; Petenia splendida

description and notes: lithograph; printed by $W$. West

article: Güther, Albert. "An account of the fishes

of the states of Central America, based on

collections made by Capt. J.M. Dow, F. Godman,

Esq., and 0. Salvin, Esq." 6:377-494.

Plate 80

subject: Hemirhombus ovalis; Citharichthys spilopterus

description and notes: lithograph; printed by $W$. West

article: Günther, Albert. "An account of the fishes

of the states of Central America, based on

collections made by Capt. J.M. Dow, F. Godman, Esq., and 0. Salvin, Esq." 6:377-4y4. 
Volume 9 (1877)

Plate 85

subject: Camarhynchus variegatus [female and male]

description and notes: hand-colored lithograph; printed by M. \& N. Hanhart

article: Salvin, Osbert. "On the avifauna of the

Galapagos Archipelago." y:447-510.

Plate 86

subject: Camarhynchus habeli [female and male]

description and notes: hand-colored lithograph; printed by M. \& N. Hanhart

article: Salvin, Osbert. "On the avifauna of the Galapagos Archipelago." 9:447-510.

Plate 87

subject: Larus fuliginosus [adult and juvenile] description and notes: hand-colored lithograph; printed by M. \& N. Hanhart; signed "JGK"; figures shown $2 / 5$ natural size article: Salvin, Osbert. "On the avifauna of the Galapagos Archipelago." 9:447-510.

Plate 88

subject: Oestrelata phaeopygia; Procellaria tethys

description and notes: hand-colored lithograph; printed by M. \& N. Hanhart; signed "JGK";

figures shown $3 / 5$ natural size

article: Salvin, Osbert. "On the avifauna of the Galapagos Archipelago." 9:447-510.

Plate 89

subject: Spheniscus mendiculus

description and notes: hand-colored lithograph; printed by $M$. \& N. Hanhart; figure shown $2 / 5$ natural size

article: Salvin, Osbert. "On the avifauna of the Galapagos Archipelago." 9:447-510. 


\section{Plate 22}

subject: Casuarius casuarius

description and notes: hand-colored lithograph; printed by Mintern Bros.; plate signed J.G. Keulemans del. et lith.; figure shown $3 / 5$ natural size

article: Kothschild, Walter and W.P. Pycraft. "A monograph of the genus Casuarius. With a dissertation on the morphology and phylogeny of the Palaeognathae (Ratitae and Crypturi) and Neognathae (Carinatae)." 15:109-290.

Plate 23

subject: Casuarius casuarius beccarii

description and notes: hand-colored lithograph; printed by Mintern Bros.; plate signed J.G. Keulemans del. et lith.

article: Rothschild, Walter and W.P. Pycraft. "A monograph of the genus Casuarius. With a dissertation on the morphology and phylogeny of the Palaeognathae (Ratitae and Crypturi) and Neognathae (Carinatae)." 15:109-290.

Plate 24

subject: Casuarius casuarius salvadorii

description and notes: hand-colored lithograph; printed by Mintern Bros.; plate signed J.G. Keulemans del. et lith.; figure shown $3 / 5$ natural size

article: Rothschild, Walter and W.P. Pycraft. "A monograph of the genus Casuarius. With a dissertation on the morphology and phylogeny of the Palaeognathae (Ratitae and Crypturi) and Neognathae (Carinatae)." 15:109-290.

Plate 25

subject: Casuarius casuarius australis description and notes: hand-colored lithograph; printed by Mintern Bros.; plate signed J.G. Keulemans del. et lith.

article: Rothschild, Walter and W.P. Pycraft. "A monograph of the genus Casuarius. With a dissertation on the morphology and phylogeny of the Palaeognathae (Ratitae and Crypturi) and Neognathae (Carinatae)." 15:109-290. 
Plate 26

subject: Casuarius casuarius violicollis

description and notes: hand-colored lithograph; printed by Mintern Bros.; plate signed J.G. Keulemans del. et lith.

article: Rothschild, Walter and W.P. Pycraft. "A monograph of the genus Casuarius. With a dissertation on the morphology and phylogeny of the Palaeognathae (Ratitae and Crypturi) and Neognathae (Carinatae)." 15:109-290.

Plate 27

subject: Casuarius casuarius intensus

description and notes: hand-colored lithograph; printed by Mintern Bros.; plate signed J.G. Keulemans del. et lith.; figure shown $3 / 5$ natural size

article: Rothschild, Walter and W.P. Pycraft. "A monograph of the genus Casuarius. With a dissertation on the morphology and phylogeny of the Palaeognathae (Ratitae and Crypturi) and Neognathae (Carinatae)." 15:109-290.

Plate 28

subject: Casuarius bicarunculatus

description and notes: hand-colored lithograph; printed by Mintern Bros.; plate signed J.G. Keulemans del. et lith.; figure shown $3 / 5$ natural size

article: Rothschild, Walter and W.P. Pycraft. "A monograph of the genus Casuarius. With a dissertation on the morphology and phylogeny of the Palaeognathae (Ratitae and Crypturi) and Neognathae (Carinatae)." 15:109-290.

Plate 29

subject: Casuarius uniappendiculatus

description and notes: hand-colored lithograph; printed by Mintern Bros.; plate signed J.G. Keulemans del. et lith.

article: Rothschild, Walter and W.P. Pycraft. "A monograph of the genus Casuarius. With a dissertation on the morphology and phylogeny of the Palaeognathae (Ratitae and Crypturi) and Neognathae (Carinatae)." 15:109-290. 
Plate 30

subject: Casuarius uniappendiculatus [adult and young ]

description and notes: hand-colored lithograph; printed by Mintern Bros.; plate signed J.G. Keulemans del. et lith.; figures shown $3 / 5$ natural size

article: Rothschild, Walter and W.P. Pycraft. "A monograph of the genus Casuarius. With a dissertation on the morphology and phylogeny of the Palaeognathae (Ratitae and Crypturi) and Neognathae (Carinatae)." 15:109-290.

Plate 31

subject: Casuarius uniappendiculatus occipitalis description and notes: hand-colored lithograph; printed by Mintern Bros.; plate signed J.G. Keulemans del. et lith.

article: Rothschild, Walter and W.P. Pycraft. "A monograph of the genus Casuarius. With a dissertation on the morphology and phylogeny of the Palaeognathae (Ratitae and Crypturi) and Neognathae (Carinatae)." 15:109-290.

Plate 32

subject: Casuarius uniappendiculatus aurantiacus description and notes: hand-colored lithograph; printed by Mintern Bros.; plate signed J.G. Keulemans del. et lith.; figure shown $3 / 5$ natural size

article: Rothschild, Walter and W.P. Pycraft. "A monograph of the genus Casuarius. With a dissertation on the morphology and phylogeny of the Palaeognathae (Ratitae and Crypturi) and Neognathae (Carinatae)." 15:109-290.

Plate 33

subject: Casuarius philipi

description and notes: hand-colored lithograph; printed by Mintern Bros.; plate signed J.G. Keulemans del. et lith.

article: Rothschild, Walter and W.P. Pycraft. "A monograph of the genus Casuarius. With a dissertation on the morphology and phylogeny of the Palaeognathae (Ratitae and Crypturi) and Neognathae (Carinatae)." 15:109-290. 
Plate 34

subject: Casuarius papuanus

description and notes: hand-colored lithograph; printed by Mintern Bros.; plate signed J.G. Keulemans del. et lith.; figure shown $3 / 5$ natural size

article: Rothschild, Walter and W.P. Pycraft. "A monograph of the genus Casuarius. With a dissertation on the morphology and phylogeny of the Palaeognathae (Ratitae and Crypturi) and Neognathae (Carinatae)." 15:109-290.

Plate 35

subject: Casuarius papuanus edwardsi

description and notes: hand-colored lithograph; printed by Mintern Bros.; plate signed J.G. Keulemans del. et lith.

article: Kothschild, Walter and W.P. Pycraft. "A monograph of the genus Casuarius. With a dissertation on the morphology and phylogeny of the Palaeognathae (Ratitae and Crypturi) and Neognathae (Carinatae)." 15:109-290.

Plate 36

subject: Casuarius picticollis

description and notes: hand-colored lithograph; printed by Mintern Bros.; plate signed J.G. Keulemans del. et lith.; figure shown $3 / 5$ natural size

article: Rothschild, Walter and W.P. Pycraft. "A monograph of the genus Casuarius. With a dissertation on the morphology and phylogeny of the Palaeognathae (Ratitae and Crypturi) and Neognathae (Carinatae)." 15:109-290.

Plate 37

subject: Casuarius picticollis hecki

description and notes: hand-colored lithograph; printed by Mintern Bros.; plate signed J.G. Keulemans del. et lith.

article: Rothschild, Walter and W.P. Pycraft. "A monograph of the genus Casuarius. With a dissertation on the morphology and phylogeny of the Palaeognathae (Ratitae and Crypturi) and Neognathae (Carinatae)." 15:109-290. 
KEULEMANS, John Gerrard

165

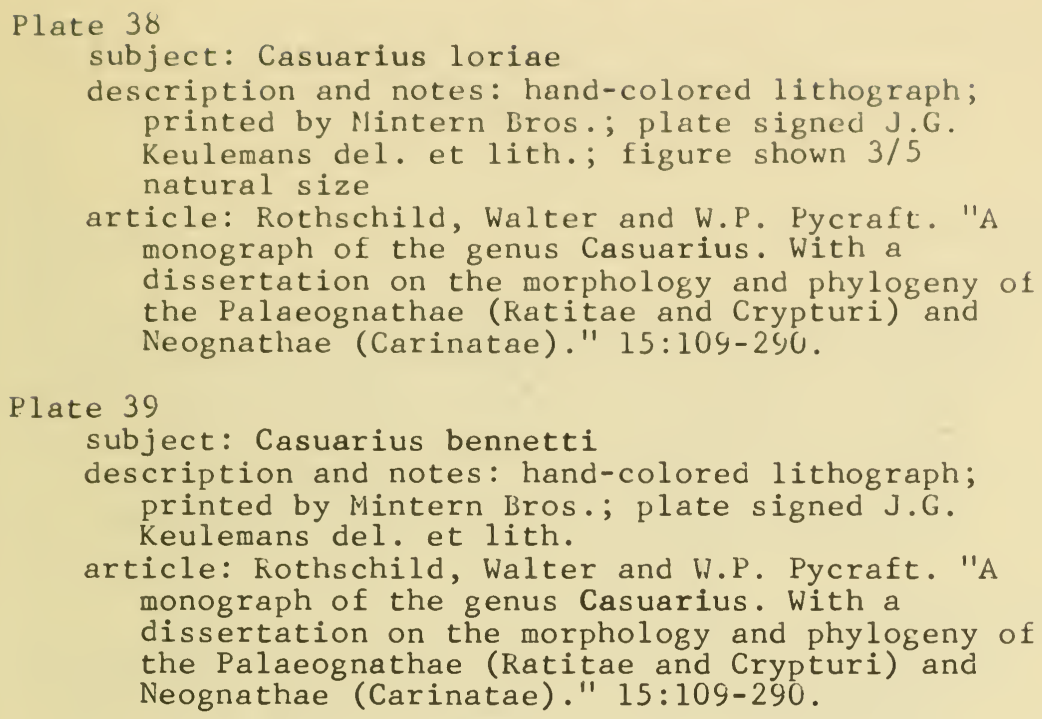


Volume 13 (1895)

\section{Plate 45}

subject: Stereosoma celebense

description and notes: chromolithograph; printed by West, Newman; plate signed L.B. King del., M.P. Parker chromo.

article: Hickson, Sydney J. "A revision of the genera of the alcyonaria stolonifera, with a description of one new genus and several new species." $13: 325-347$.

Plate 46

subject: Clavularia garciae

description and notes: chromolithograph; printed by West, Newman; plate signed L.B. King del., M.P. Parker chromo.

article: Hickson, Sydney J. "A revision of the genera of the alcyonaria stolonifera, with a description of one new genus and several new species." $13: 325-347$.

Plate 47

subject: Clavularia reptans

description and notes: chromolithograph; printed by West, Newman; plate signed M.P. Parker chromo., L.B. King del.

article: Hickson, Sydney J. "A revision of the genera of the alcyonaria stolonifera, with a description of one new genus and several new species." $13: 325-347$.

Plate 48

subject: Clavularia celebensis

description and notes: chromolithograph; printed by West, Newman; plate signed L.B. King del., M.P. Parker chromo.

article: Hickson, Sydney J. "A revision of the genera of the alcyonaria stolonifera, with a description of one new genus and several new species." 13:325-347. 


\section{KNIGHT, Horace}

\section{Volume 14 (1898)}

Plate 18: "Oriental Hesperiidae" subject: Celaenorrhinus balukinus [male]; Celaenorrhinus orbiferus [male]; Celaenorrhinus inaequalis [male]; Celaenorrhinus dentatus [male]; Celaenorrhinus fluvescens [male]; Celaenorrhinus saturatus [male]; Celaenorrhinus lativittus [male]; Celaenorrhinus maculicornis [male]; Celaenorrhinus affinis [female]; Celaenorrhinus batchianus [male]; Coladenia agnioides [male]; Coladenia sobrina [male]; Satarupa fumosa [male]; Suastus bipunctus Swinh. [male]; Suastus sala Hew. [male]; Astictopterus olivascens Moore [male]; Astictopterus henrici Holland [male]; Tapena minuscula [male]; Tapena hampsoni [male]; Caprona saraya Doherty [male]; Baracus hampsoni [male]; Scobura martini [female]; Pedestes maculicornis [male]; Arnetta vindhiana Moore [male]; Pedestes fuscicornis [male]; Lophoides purpurascens [male and female]; Lophoides binotatus [female] description and notes: chromolithograph; printed by West, Newman; plate signed Horace Knight ad nat. lith.

article: Elwes, H.J. and James Edwards. "A revision of the oriental Hesperiidae." 14:101-324. 
Plate 19: "Oriental Hesperiidae"

subject: Scobura umbrosa [female]; Scobura bipunctata [female]; Aeromachus stigmata Moore [male]; Sepa cicatrosa [male]; Parnara bipunctata [male]; Aeromachus discreta Plötz; Aeromachus inachus Mén. [male]; Sepa guttulifera [male]; Zographetus ogygioides [male]; Aeromachus dubius [male]; Aeromachus indistincta Moore [male]; Scobura concinna [female]; Zographetus auriferus [male]; Telicota prusias Feld. [male]; Telicota simplex [male]; Scobura fenestrata [male]; Plastingia aurantiaca [male]; Plastingia similis [male]; Plastingia fruhstorferi Mab. [male]; Gehenna angulifera [male]; Augiades majuscula [male]; Sepa ciliata [male]; Pamphila niveomaculatus $O b$. [female]; Aeromachus javanicus [male]; Sepa cinnamomea [male]; Telicota insularis [male and female]; Augiades siva Moore [male]

description and notes: chromolithograph; printed by West, Newman; plate signed Horace Knight ad nat. lith.

article: Elwes, H.J. and James Edwards. "A revision of the oriental Hesperiidae." 14:101-324.

Plate 20: "Oriental Hesperiidae" see Unsigned, 14: Plate 20

Plate 21: "Oriental Hesperiidae" see Unsigned, 14: Plate 21

Volume 19 (1909-1910)

Plate 2: "Rhynchota"

subject: Caura leggei Dist.; Ptyelus niveus Dist.; Aspongopus alternatus Dist.; Carbula bicolor Dist.; Lepyronia aethiops Dist.; Awemba typica Dist.; Acanthomia insignis Dist.; Carbula fuscata Dist.; Ranatra fuscoannulata Dist.; Cenaeus semiflavus Dist.; Dysdercus pretiosus Dist.; Harpactor ornatellus Dist.; Plectropoda bicolor Hagl.; Holopterna wollastoni Dist.; Holopterna affinis Dist.; Mygdonia montana Dist.; Anoplocnemis signata Dist.

description and notes: chromolithograph; printed by West, Newman; plate signed Horace Knight del. et lith.

article: Distant, W.L. "Ruwenzori Expedition reports. 9. Rhynchota." 19:67-84. 
Plate 4: "Lepidoptera Phalaenae"

subject: Epitoxis albicincta [male and female];

Apisa metarctioides [male]; Metarctia

pulverea [female]; Diacrisia melanodisca

[male and female]; Agrotis elaeopis [female];

Episilia rhodopea [male]; Lycophotia

leucoplaga [female]; Borolia pyrostrota

[female]; Borolia phaeopasta [female];

Arboricornis chrysopepla [male]; Ariathisa

semiluna [male]; Calymnia ethiopica [female];

Calamistis obliquifascia [male]; Xylostola

olivata [female]; Tarache niphogona [female];

Hypoglaucitis polycyma [female]; Plusia

cupreomicans [female]; Plusia aranea

[female]; Pleurona lepticyma [female];

Parathermes nubilata [female]; Acantholipes

ochrota [male]; Catada phaeopasta [male];

Apluda incincta [male]; Bleptina nephelopera

[male]; Hypena recurvata [female]; Pseudometa

castanea [male]; Taragama butiti [female];

Taragama diplocyma [male]; Anadiasa

leucocyma [male]; Remigia pectinata [male];

Olapa melanocera [female]; Leucoma atricosta

[male]; Diota reticulata [female];

Tetraphleps ruficeps [male]; Zana

trifasciata [male]; Ramesa macrodonta [male];

Beralade strigifascia [male]; Metarctia

flaviciliata [male]; Chrysopsyche leucostigma [male]; Goodia oriens [male]; Euproctis melalepia [male]; Euproctis croceisticta [male]; Stenostaura impedita [male]; Osteodes pervittata [male]; Macaria trizonaria [male];

Macaria atriclathrata [male]; Tephrina oleochroa [male]; Zamarada chrysothyra [male]; Zamarada phaeozona [male]; Hypocrosis glaucaria [male]; Hypocrosis maculifera [male]; Psilocerea stictigramma [male]; Psilocerea craspigonia [male]; Psilocerea curvimargo [male]; Xylopteryx prasinaria [female]; Terina chrysoptera [male]; Nemoria brunneifrons [female]; Comibaena biviaria [female]; Larentia heteromorpha [male];

Larentia chlorostola [male]; Cidaria

thermochroa [male]; Marshaliiana arcifera [male]; Emmatheudes lentistrigalis [male]; Pilocrocis patagialis [male]; Pilocrocis

laralis [male]; Glyphodes aniferalis

[female]; Polythlipta guttiferalis [female]

description and notes: chromolithograph; printed by

West, Newman; plate signed Horace Knight del. et

lith.

article: Hampson, George F. "Ruwenzori Expedition

reports. 11. Lepidoptera Heterocera." 19:103-140. 
Plate 5: "Lepidoptera Rhopalocera from Mt. Ruwenzori, Entebbe, and Lagos"

subject: Gnophodes grogani E.M. Sharpe [male and female]; Gnophodes minchini Heron [male]; Gnophodes minchini forma $n$. Magniplaga Heron [male]; Ergolis pagensteckeri forma n. aurantiaca Heron [male]; Ergolis pagensteckeri Suffert [male]; Charaxes opinatus Heron [male]; Gnophodes chelys Fab. [male]; Gnophodes diversa Butler [male]; Gnophodes parmeno Doubl.\& Hew. [male]; Acraea amicitiae Heron [male]; Oxypalpus wollastoni Heron [male and female]; Chioneigia leggei Heron [male and female]; Uranothauma falkensteinii Dewitz [male and female]; Uranothauma delatorum Heron [male and female]; Harpendyreus reginaldi Heron [male and female] description and notes: chromolithograph; printed by West, Newman; plate signed Horace Knight del. et lith.

article: Heron, F.A. "Ruwenzori Expedition reports. 12. Lepidoptera Rhopalocera." 19:141-178.

Plate 6: "Coleoptera from Mt. Ruwenzori" subject: Lycus vittatus Gahan [male]; Lycus (Acantholycus) modestus Gahan [male and female]; Lycus (Lycostomus) runsoriensis Gahan [male]; Alaus trifasciatus Gahan; Melyris monticola Gahan; Clytus (Perissus) wollastoni Gahan; Nothophysis johnstoni Lameere [male and female]; Sternotomis runsoriensis Gahan; Ceroplesis reticulata Gahan; Lagria rugipennis Gahan; Horia nitida Gahan; Phrynetopsis kolbei Gahan; Glenea montivaga Gahan; Entebbia bipunctata Gahan [female]; Dirphya delecta Gahan; Phrystola ellioti Gahan

description and notes: chromolithograph; printed by West, Newman; plate signed Horace Knight del. et lith.

article: Arrow, Gilbert J., et al. "Ruwenzori

Expedition reports. 14.'Coleoptera." 19:185-236. 
Plate 7: "Coleoptera from Mt. Ruwenzori"

subject: Macrolopha quadrimaculata Gahan; Öides pallidipennis Gahan; Diacantha nigronotata Gahan; Diacantha nigronotata var.; Aulamorphus variabilis Gahan; Epilachna serva Arrow; Adoretus flavovittatus Arrow; Agrilus continuatus Waterh.; Glycyphana (Gametis) tigrina Arrow; Epilachna gemmifera Arrow; Epilachna lucifera Arrow; Allagogus brunneus Gahan; Blosyrus seminitidus Mshl.; Epilachna nympha Arrow; Amphitmetus leggei Mshl.; Amphitmetus foveipennis Mshl.; Amphitmetus planicollis Mshl.; Apotmetus montanus Msh1.; Disodontogenus wollastoni Msh1.

description and notes: chromolithograph; printed by West, Newman; plate signed Horace Knight del. et lith.

article: Arrow, Gilbert J., et al. "Ruwenzori Expedition reports. 14. Coleoptera." 19:185-236.

Volume 20 (1912-1915)

Plate 34: "Rhynochota from Dutch New Guinea" subject: Rhotala albopunctata; Rhotala nebulosa; Ricania noctua; Ricania subglauca; Euricania stellata; Papuanella mirabilis; Heronax wollastoni; Utakwana rubromaculata; Dindymus croesus; Dindymoides abdominalis; Grapaldus corticinus; Aufidus balteatus; Euacanthus papuensis; Bhooria klossi; Megastethodon modestus; Leptataspis elegantula; Folengus papuensis

description and notes: chromolithograph; printed by West, Newman; plate signed Horace Knight ad nat. lith.

article: Distant, W.L. "Report on the Khynchota collected by the Wollaston Expedition in Dutch New Guinea.' 20:335-362. 
Plate 38: "Diptera from Dutch New Guinea" subject: Tipula de-meijerei; Ptilocera violacea; Chrysopilus binoculatus; Maira wollastoni Austen; Promachus noscibilis Austen; Dissoptera pollinosa; Plesiocyptera divisa Walker; Phytalmia? wollastoni; Ortaloptera cleitamina; Rioxa flava

description and notes: chromolithograph; printed by Menpes Press; plate signed Horace Knight ad. nat. del.

article: Edwards, F.W. and E.E. Austen. "Keport on the Diptera collected by the British Ornithologists' Union Expedition and the Wollaston Expedition in Dutch New Guinea. With a section on the Asilidae." 20:391-424.

Plate 39: "Coleoptera from Dutch New Guinea" subject: Dysopirhinus costatus Marshall;

Ectatocyba verrucosa Marshal1; Lophocheirus wollastoni Marshal1; Orthorrhinus postoculatus Marshal1; Alcides parentheticus Marshal1; Ptolycus nodosus Marshall;

Arachnopus planatus Marshal1; Arachnopus biplagiatus Marshal1; Arachnopus lanceolatus Marsha11; Colobodes cavisquamis Marsha11; Sparganobasis subcruciatus Marshall;

Heteronyx colossus Arrow; Papuana angusta Arrow; Strongylium wollastoni Blair; Setenis costipennis Blair; Tmesisternus taeniatus Gahan; Tmesisternus cinctus Gahan; Cornuscoparia wollastoni Gahan; Tmesisternus multiplicatus Gahan; Tmesisternus modestus Gahan; Ichthyosoma (Elais) albomaculatum Gahan; Tmesisternus (Polyxo) bialbatus Gahan; Trigonoptera albonotata Gahan; Tmesisternus (Polyxo) laticollis Gahan

description and notes: photoprint; printed by West, Newman; plate signed Horace Knight del. article: Arrow, Gilbert J., et al. "Report on the Coleoptera collected by the British Ornithologists' Union Expedition and the Wollaston Expedition in Dutch New Guinea." $20: 497-542$. 


\section{Volume $10(1879)$}

Plate 83: "Heart of Ceratodus" subject: Ceratodus forsteri

description and notes: lithograph; printed by Hanhart; plate signed E. Ray Lankester ad nat. del., Smit lith.

article: Lankester, E. Ray. "On the hearts of Ceratodus, Protopterus, and Chimaera, with an account of undescribed pocket valves in the conus arteriosus of Ceratodus and of Protopterus." 10:493-505.

Plate 84: "Heart of Protopterus \& Chimaera" subject: Protopterus annectens; Chimaera monstrosa

description and notes: lithograph; printed by Hanhart; plate signed E. Ray Lankester ad nat. del., Smit lith.

article: Lankester, E. Ray. "On the hearts of Ceratodus, Protopterus, and Chimaera, with an account of undescribed pocket valves in the conus arteriosus of Ceratodus and of Protopterus." 10:493-505.

\section{Volume 11 (1885)}

Plate 80: "Anatomy of Scorpio" subject: Androctonus funestus; Brotheas subnitens Gervais; Scorpio (Buthus) cyaneus; Androctonus occitanus

description and notes: hand-colored lithograph; printed by Hanhart; plate signed E. Ray Lankester del, C. Berjeau lith. article: Lankester, E. Ray, W.B.S. Benham and E.J. Beck. "On the muscular and endoskeletal systems of Limulus and Scorpio; with some notes on the anatomy and generic characters of scorpions." 11:311-384. 


\section{LEAR, Edward (1812-1888)}

Volume 1 (1835)

Plate 3

subject: Cynictis steedmannii

description and notes: hand-colored etching; plate signed E. Lear del., Zeitter sc.

article: Ogilby, W. "On the characters and description of a new genus of Carnivora, called Cynictis." $1: 29-34$.

Plate 4

subject: Lagotis cuvieri

description and notes: hand-colored etching; plate signed E. Lear del., Zeitter sc.

article: Bennett, E.T. "On the Chinchillidae, a family of herbivorous Rodentia, and on a new genus referrible [sic] to it." $1: 35-64$.

Plate 21

subject: Crtptoprocta ferox

description and notes: hand-colored engraving;

plate signed Lear del., Zeitter sc.

article: Bennett, E.T. "Notice of a mammiferous animal from Madagascar, constituting a new form among the viverridous carnivora." 1:137-140.

Plate 24

subject: Felis leo goojratensis

description and notes: hand-colored engraving;

plate signed Lear del., Zeitter sc.

article: Smee, Walter. "Some account of the maneless lion of Guzerat." 1:165-174.

Plate 37

subject: Macropus parryie

description and notes: hand-colored engraving;

plate signed Lear del., Zeitter sc.

article: Bennett, E.T. "Some account of Macropus

parryi, a hitherto undescribed species of

kangaroo from New South Wales." 1:295-300. 


\section{Volume 2 (1841)}

Plate 6

subject: Pteropus whitei

description and notes: hand-colored engraving;

plate signed E. Lear del., Zeitter sc.

article: Bennett, E.T. "On a remarkable species of pteropine bat." 2:31-38.

Plate 16

subject: Octodon cumingil

description and notes: hand-colored engraving;

Plate signed E. Lear del., Zeitter sc.; signed

article: Bennett, E.T. "On the genus Octodon, and

on its relations with Ctenomys, Blainv., and

Poephagomys, F. Cuv.: including a description of a new species of Ctenomys." $2: 75-86$.

Plate 17

subject: Ctenomys magellanicus

description and notes: hand-colored engraving; Plate signed E. Lear del., Zeitter sc.; signed article: Bennett, E.T. "On the genus Octodon, and on its relations with Ctenomys, Blainv., and Poephagomys, F. Cuv.: including a description of a new species of Ctenomys." 2:75-86. 
MACLISE, Joseph

Volume 3 (1849

Plate 37

subject: Phascolomys vombatus; Phascolomys latifrons

description and notes: lithograph; plate signed Joseph Maclise Esqr. delt., Hullmandel \& Walton lith.; two-page plate

article: Owen, [Professor]. "On the osteology of the Marsupialia. (Part II.) Comparison of the skulls of the wombats of continental Australia and of Van Diemen's Land, whereby their specific distinction is established." 3:303-306. 


\section{MARTIN}

\section{Volume 1 (1835)}

Plate 5

subject: Lagotis cuvieri; Chinchilla lanigera description and notes: lithograph; plate signed Martin del., W. Wing lith.; printed by Hullmandel \& Walton; figures show stomach and caecum of the species

article: Bennett, E.T. "On the Chinchillidae, a family of herbivorous Fodentia, and on a new genus referrible to it." $1: 35-64$. 
MATTHEWS, M.A.A.

Volume 5 (1866)

Plate 50

subject: Centetes ecaudatus; Cavia aperea; Lepus cuniculus; Mus decumanus; Macacus nemestrinus

description and notes: lithograph; printed by M. \& N. Hanhart; plate signed M.A.A. Matthews delt., J. Erxleben lith.

article: Rolleston, [Professor]. "On the placental structures of the tenrec (Centetes ecaudatus), and those of certain other Mammalia; with remarks on the value of the placental system of classification." 5:285-316. 
McINTOSH, W.C.

Volume $9(1877)$

Plate 67: "British Annelida"

subject: Spinther oniscoides Johnst.; Eunoa

nodosa Sars; Dasylepis asperrima Sars;

Lagisca propinqua Malmgren; Malmgrenia

castanea; Malmgrenia andreapolis

description and notes: lithograph; printed by

Mintern Bros.; plate signed W.C.M. del., G.H. Ford lith.

article: M'Intosh, W.C. "On British Annelida." 9:371-394.

Plate 68: "British Annelida"

subject: Harmothoë sibbaldii; Harmothoë

zetlandica; Polynoë floccosa Sav.; Harmothoë

imbricata; Harmothoë areolata Grube;

Malmgrenia castanea

description and notes: lithograph; printed by Mintern Bros.; plate signed W.C.M. del., G.H. Ford lith.

article: M'Intosh, W.C. "On British Annelida." $9: 371-394$.

Plate 69: "British Annelida"

subject: Harmothoë zetlandica; Harmothoë macleodi; Harmothoë antilopes; Harmothoë haliaeeti; Harmothoë marphysae; Harmothoë lunulata Delle Chiaje

description and notes: lithograph; printed by Mintern Bros.; plate signed W.C.M. del., G.H. Ford lith.

article: M'Intosh, W.C. "On British Annelida." $9: 371-394$.

Plate 70: "British Annelida"

subject: Evarne impar; Hermadion assimile;

Enipo kinbergi Mgrn.?; Acholoë astericola

Delle Chiaje; Sthenelais Iimicola Ehlers;

Sigalion buskii; Sthenelais? zetlandica

description and notes: lithograph; printed by

Mintern Bros.; plate signed Robta. fig. 14 del.,

Caetera W.C.M. del., G.H. Ford lith.

article: M'Intosh, W.C. "On British Annelida." $9: 371-394$. 
Plate 71: "Annelida of the 'Porcupine""

subject: Euphrosyne lanceolata; Chloëia fucata De Quatrefages?; Eunoa hispanica; Lagisca jeffreysi; Evarne johnstoni

description and notes: lithograph; printed by Mintern Bros.; plate signed W.C.M. del., G.H. Ford lith.

article: M'Intosh, W.C. "On the Annelida of the 'Porcupine' Expedition of 1869 and $1870 . "$ $y: 395-416$.

Plate 72: "Annelida of the 'Porcupine""

subject: Antinoë funmarchica Mgrn.; Antinoë mollis M. Sars; Phyllantinoë mollis; Lepidasthenia blainvillii Aud. \& Ed.; Lepidasthenia longissima Blainville; Eupanthalis kinbergi; Sthenelais atlantica; Sthenelais jeffreysi; Sthenelais boa Johnst. description and notes: 1ithograph; printed by Mintern Bros.; plate signed W.C.M. del., G.H. Ford lith.

article: M'Intosh, W.C. "On the Annelida of the 'Porcupine' Expedition of 1869 and $1870 . "$ $9: 395-416$.

Plate 73: "Annelida of the 'Porcupine"" subject: Sthenelais jeffreysi; Eusthenelais hibernica; Leanira hystricis Ehlers.; Leanira yhleni Mgrn.?; Psammolyce herminiae Aud. \& Ed.?; Lagisca jeffreysi

description and notes: lithograph; printed by Mintern Bros.; plate signed W.C.M. del., G.H. Ford lith.

article: M'Intosh, W.C. "On the Annelida of the 'Porcupine' Expedition of 1869 and 1870." 9:395-416. 
McLEAY, William Sharp (1792-1865)

Volume 1 (1835)

Plate 26 subject: Urania fernandina

description and notes: hand-colored engraving; plate signed W.S. McLeay del., Swaine Sc.; figures show egg, larva, cocoon and chrysalis article: MacLeay, W.S. "A few remarks tending to illustrate the natural history of two annulose genera, viz. Urania of Fabricius, and Mygale of Walckanaer." $1: 179-194$. 
Volume 12 (1890)

Plate 58: "Pachychalina, Siphonochalina, Spinosella"

subject: Siphonochalina ceratosa; Siphonochalina spiculosa; Pachychalina variabilis; Siphonochalina procumbens; Spinosella plicifera; Spinosella sororia var. dilatata; Spinosella sororia

description and notes: lithograph; plate signed Mintern Bros. del. et lith.

article: Dendy, Arthur. "Observations on the West-Indian Chalinine sponges, with descriptions of new species." 12:349-368.

Plate 59

subject: Spinosella sororia; Spinosella velata; Spinosella sororia var. fruticosa

description and notes: lithograph; plate signed Mintern Bros. del. et lith.; figures shown $1 / 2$ natural size

article: Dendy, Arthur. "Observations on the West-Indian Chalinine sponges, with descriptions of new species." 12:349-368.

Plate 60

subject: Spinosella plicifera; Pachychalina variabilis

description and notes: lithograph; plate signed Mintern Bros. del. et lith.

article: Dendy, Arthur. "Observations on the West-Indian Chalinine sponges, with descriptions of new species." 12:349-368.

Plate 61

subject: Spinosella maxima

description and notes: lithograph; plate signed Mintern Bros. del. et lith.; figure shown $3 / 4$ natural size

article: Dendy, Arthur. "Observations on the West-Indian Chalinine sponges, with descriptions of new species." 12:349-368. 
Plate 62

subject: Siphonochalina procumbens;

Siphonochalina ceratosa; Siphonochalina spiculosa

description and notes: lithograph; plate signed

Mintern Bros. del. et lith.; figures shown $1 / 2$ natural size

article: Dendy, Arthur. "Observations on the

West-Indian Chalinine sponges, with descriptions of new species." 12:349-368.

Plate 63

subject: Spinosella sororia var. elongata; Spinosella sororia var. dilata

description and notes: lithograph; plate signed Mintern Bros. del. et lith.; figures shown $1 / 2$ natural size

article: Dendy, Arthur. "Observations on the West-Indian Chalinine sponges, with descriptions of new species." 12:349-368. 
MINTERN, Robert

Volume 9 (1877)

Plate 92: "New Sphingidae \& Transformations" subject: Chaerocampa mirabilis Butler; Pergesa aegrota Butler; Pergesa gloriosa Butler; Panacra regularis Butler; Daphnis minima Butler; Pseudosphinx cyrtolophia Butler; Panacra ella Butler; Chaerocampa silhetens is Walker [larva and pupa]; Acherontia morta Hübner [larva]; Acherontia medusa Butler [larva and pupa]; Smerinthus planus Walker [larva]

description and notes: hand-colored lithograph; printed by Mintern Bros.; plate signed R. Mintern del. et lith.

article: Butler, Arthur Gardiner. "Revision of the heterocerous Lepidoptera of the family Sphingidae." 9:511-644.

Plate 93: "New Species of Sphingidae" subject: Triptogon spectabilis Butler; Triptogon fuscescens Butler; Triptogon oriens Butler; Basiana exusta Butler; Triptogon massurensis Butler; Triptogon albicans Butler; Ambulyx turbata Butler; Ambulyx rhodoptera Butler; Ambulyx lahora Butler

description and notes: chromolithograph; printed by Mintern Bros.; plate signed R. Mintern del. et Chromo-lith.

article: Butler, Arthur Gardiner. "Revision of the heterocerous Lepidoptera of the family Sphingidae." 9:511-644.

\section{Volume 11 (1885)}

Plate 42

subject: Chelys fimbriata

description and notes: lithograph; printed by Mintern Bros.; plate signed R. Mintern del. et lith.; figure shown $1 / 3$ natural size

article: Günther, Albert. "Observations on some rare reptiles and a Batrachian now or lately living in the Society's Menagerie." 11:215-222. 
Plate 43

subject: Metopoceros cornutus

description and notes: lithograph; printed by Mintern Bros.; plate signed $\mathrm{k}$. Mintern del. et lith.; figure shown $1 / 3$ natural size

article: Günther, Albert. "Observations on some rare reptiles and a Batrachian now or lately living in the Society's Menagerie." 11:215-2 22 .

Plate 44

subject: Metopoceros cornutus

description and notes: lithograph; printed by Mintern Bros.; plate signed R. Mintern del. et lith.; head and skull shown

article: Günther, Albert. "Observations on some rare reptiles and a Batrachian now or lately living in the Society's Menagerie." 11:215-222.

Plate 45

subject: Tejus rufescens

description and notes: hand-colored lithograph; printed by Mintern Bros.; plate signed R.

Mintern del. et lith.; figure shown natural "Tize; genus incorrectly given on plate as

article: Günther, Albert. "Observations on some rare reptiles and a Batrachian now or lately living in the Society's Menagerie." 11:215-222.

Plate 46

subject: Ceratophrys ornata [male]

description and notes: chromolithograph; printed by Mintern Bros.; plate signed R. Mintern del. et lith.; figure shown natural size

article: Günther, Albert. "Observations on some rare reptiles and a Batrachian now or lately living in the Society's Menagerie." 11:215-222.

Plate 47

subject: Schedophilus medusophagus

description and notes: chromolithograph; printed by Mintern Bros.; plate signed R. Mintern del. et lith.

article: Günther, Albert. "Description of a specimen of Schedophilus medusophagus, a fish new to the British fauna." 11:223-224. 
Volume 12 (1890)

Plate 51: "Libellulinae"

subject: Tramea darwinii [female]; Fylgia amazonica [male]; Fylgia amazonica [male, immature]; Antidythemis trameiformis [male]; Rhyothemis apicalis [femalej; Rhyothemis cuprina [female]; Perithemis intensa [male]; Perithemis bella [male and female]; Hydrobasileus vittatus [male]

description and notes: hand-colored lithograph; printed by Mintern Bros.; plate signed R. Mintern del. et lith.

article: Kirby, W.F. "A revision of the subfamily Libellulinae, with descriptions of new genera and species." 12:249-348.

Plate 52: "Libellulinae"

subject: Pseudothemis zonata [male]; Celithemis fasciata [male]; Miathyria pusilla [male]; Tetrathemis flavescens [male]; Nannodythemis australis [male]; Fylla exigua [male]; Pseudomacromia torrida [male]; Thermochoria equivocata [male]; Misagria parana [male]; Rhodopygia cardinalis [male]

description and notes: hand-colored lithograph; printed by Mintern Bros.; plate signed R. Mintern del. et lith.

article: Kirby, W.F. "A revision of the subfamily Libellulinae, with descriptions of new genera and species." 12:249-348.

Plate 53: "Libellulinae"

subject: Cannacria batesii [male]; Trithemis(?) attenuata [male]; Aethriamanta brevipennis [male]; Untamo apicalis [female]; Lyriothemis braueri [female]; Deielia fasciata [female]; Pseudoleon superbus [male]; Nesoxenia cingulata [female]; Anatya anomala [male] description and notes: hand-colored lithograph; printed by Mintern Bros.; plate signed R. Mintern del. et lith. article: Kirby, W.F. "A revision of the subfamily Libellulinae, with descriptions of new genera and species." 12:249-348. 
Plate 54: "Libellulinae"

subject: Orthemis flavopicta [male]; Neurothemis affinis [male]; Macrothemis hemichlora

[temale]; Belonia foliata [female];

Tyriobapta torrida [male and female];

Protorthemis celebensis [male]; Neurothemis disparilis [male]; Brachydiplax indica [female]

description and notes: hand-colored lithograph; printed by Mintern Bros.; plate signed $\mathrm{K}$.

Mintern del. et lith.

article: Kirby, W.F. "A revision of the subfamily Libellulinae, with descriptions of new genera and species." 12:249-348.

Plate 55: "Libellulinae"

subject: Libellula depressa [female];

Neurothemis fulvia [male]; Erythemis

peruviana [male]; Sympetrum pallidinervis

[male]; Orthetrum sabina [male]; Orthetrum caerulescens [male]

description and notes: lithograph; printed by

Mintern Bros.; plate signed R. Mintern del. et lith.; shows wings only

article: Kirby, W.F. "A revision of the subfamily Libellulinae, with descriptions of new genera and species." 12:249-348.

Plate 56: "Libellulinae"

subject: Microthemis duivenbodi [male];

Orchithemis pulcherrima [male]; Agrionoptera

4-notata [male]; Raphismia bispina [female];

Acisoma panorpoides(?) [male]; Palpopleura

jucunda [male]; Nannophya pygmaea [female];

Tetrathemis hyalina [male]

description and notes: lithograph; printed by

Mintern Bros.; plate signed R. Mintern del. et lith.; shows wings only

article: Kirby, W.F. "A revision of the subfamily Libellulinae, with descriptions of new genera and species." 12:249-348. 
Plate 57: "Libellulinae"

subject: Lepthemis vesiculosa [female];

Holotania axilena [male]; Orthemis

ferruginea [male]; Mesothemis simplicicollis

[female]; Orthemis flavopicta [male];

Protorthemis celebensis [male]; Anatya anomala [male]; Misagria parana; Cannacria batesii [male]; Zyxomma petiolatum [male]; Macrothemis hemichlora [female]

description and notes: lithograph; printed by Mintern Bros.; plate signed R. Mintern del. et lith.

article: Kirby, W.F. "A revision of the subfamily Libellulinae, with descriptions of new genera and species." 12:249-348. 
MITCHELL, W.

\section{Volume 3 (1849)}

\section{Plate 7}

subject: Hoplegnathus conwayii, Kich.;

\section{Syngnathus argus, Rich.}

description and notes: hand-colored engraving;

plate signed W. Mitchell del., J. Basire Sc.;

first species shown $1 / 3$ natural size, the second natural size

article: Richardson, John. "(Part 2.) Description of Australian fish." 3:133-185.

Plate 9

subject: Ostracion auritus, Shaw

description and notes: hand-colored engraving; plate signed W. Mitchell delt., J. Swaine sc.; figure shown natural size

article: Richardson, John. "(Part 2.) Description of Australian fish." 3:133-185.

Plate 10

see Hawkins, 3: Plate 10

\section{Plate 11}

subject: Ostracion flavigaster, Gray; Narcine tasmaniensis, Rich.

description and notes: hand-colored engraving; plate signed W. Mitchell \& W. Hawkins delt., J. Swaine sc.; first species shown natural size, the second $1 / 2$ natural size

article: Kichardson, John. "(Part 2.) Description of Australian fish." 3:133-185. 
MOORE, Frederic G. (1830-1967)

Volume 11 (1885)

Plate 12: "Transformations of Ophiderinae"

subject: Othreis fullonica [larva and pupa];

Othreis ancilla [larva and pupa]; Maenas

salaminia [larva and pupa]; Argadesa materna

[larva and pupa]; Rhytia cocale [larva and pupa]; Rhytia hypermnestra [larva]

description and notes: hanc-colored lithograph; printed by Mintern Bros.

article: Moore, F. "On the genera and species of the lepidopterous subfamily Ophiderinae inhabiting the Indian region." 11:63-76.

Plate 13: "Species of Ophiderinae"

subject: Othreis fullonica [male and female]; Othreis cajeta [male and female]; Othreis ancilla [male and female]; Khadira aurantia; Adris tyrannus [male]

description and notes: hand-colored lithograph; printed by Mintern Bros.; plate signed F.C. Moore del. et lith.

article: Moore, F. "On the genera and species of the lepidopterous subfamily Ophiderinae inhabiting the Indian region." 11:63-76.

Plate 14: "Species of Ophiderinae"

subject: Purbia discrepans [male]; Maenas salaminia; Argadesa materna [male and female]; Rhytia hypermnestra [male and female]; Rhytia cocale [male and female] description and notes: hand-colored lithograph; printed by Mintern Bros.; plate signed F.C. Moore del. et lith.

article: Moore, F. "On the genera and species of the lepidopterous subfamily Ophiderinae inhabiting the Indian region." 11:63-76. 
MOSS, A. Miles

Volume $20(1912-1915)$

Plate 7: "Peruvian Sphingidae"

subject: Cocytius antaeus medor; Protoparce mossi; Protoparce sexta paphus; Euryglottis davidianus

description and notes: chromolithograph; printed by E. Wilson; plate signed A. Miles Moss del., M.P. Parker lith.

article: Moss, A. Miles. "On the Sphingidae of Peru. With a preface by Karl Jordan." 20:73-134.

Plate 8: "Peruvian Sphingidae"

subject: Protoparce rustica rustica; Protoparce diffissa tropicalis; Protoparce scutata;

Herse cingulata; Isognathus swainsoni;

Pseudosphinx tetrio

description and notes: chromolithograph; printed by E. Wilson; plate signed A. Miles Moss del., M.P. Parker lith.

article: Moss, A. Miles. "On the Sphingidae of

Peru. With a preface by Karl Jordan." 20:73-134.

Plate 9: "Peruvian Sphingidae"

subject: Erinnyis ello; Erinnyis alope

description and notes: chromolithograph; printed by E. Wilson; plate signed A. Miles Moss del., M.P. Parker lith.

article: Moss, A. Miles. "On the Sphingidae of

Peru. With a preface by Karl Jordan." 20:73-134.

Plate 10: "Peruvian Sphingidae"

subject: Pachylia ficus; Pachylia syces syces

description and notes: chromolithograph; printed by

E. Wilson; plate signed A. Miles Moss del., M.P.

Parker lith.

article: Moss, A. Miles. "On the Sphingidae of

Peru. With a preface by Karl Jordan." 20:73-134. 
Plate 11: "Peruvian Sphingidae"

subject: Pholus fasciatus

description and notes: chromolithograph; printed by

E. Wilson; plate signed A. Miles Moss del., M.P.

Parker lith.

article: Moss, A. Miles. "On the Sphingidae of

Peru. With a preface by Karl Jordan." 20:73-134.

Plate 12: "Peruvian Sphingidae"

subject: Pholus vitis vitis; Pholus anchemolus

description and notes: chromolithograph; printed by

E. Wilson; plate signed A. Miles Moss del., M.P.

Parker lith.

article: Moss, A. Miles. "On the Sphingidae of

Peru. With a preface by Karl Jordan." 20:73-134.

Plate 13: "Peruvian Sphingidae"

subject: Pholus labruscae; Xylophanes titana

description and notes: chromolithograph; printed by

E. Wilson; plate signed A. Miles Moss del., M.P.

Parker lith.

article: Moss, A. Miles. "On the Sphingidae of

Peru. With a preface by Karl Jordan." 20:73-134.

Plate 14: "Peruvian Sphingidae"

subject: Celerio annei; Celerio lineata

Iineata; Xylophanes tersa

description and notes: chromolithograph; printed by

E. Wilson; plate signed A. Miles Moss del., M.P.

Parker lith.

article: Moss, A. Miles. "On the Sphingidae of

Peru. With a preface by Karl Jordan." 20:73-134.

Plate 15: "Peruvian Sphingidae"

subject: Cocytius antaeus medor; Protoparce

rustica rustica; Protoparce mossi;

Protoparce sexta paphus; Herse cingulata;

Euryglottis davidianus; Pachylia ficus;

Pachylia syces syces; Pseudosphinx tetrio;

Pholus labruscae; Pholus fasciatus; Pholus

vitis vitis; Xylophanes tersa; Celerio

lineata lineata; Celerio annei; Erinnyis

ello

description and notes: chromolithograph; printed by

E. Wilson; plate signed A. Miles Moss del., M.P.

Parker lith.

article: Moss, A. Miles. "On the Sphingidae of

Peru. With a preface by Karl Jordan." 20:73-134. 
MURIE, James (1832-1925)

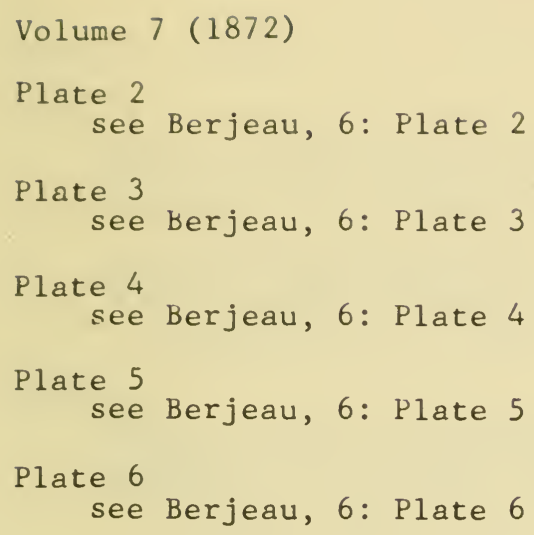

Volume $8(1874)$

Plate 25: "The Brain Nat. size and Cranial Cavity see Berjeau, 8: Plate 25

Plate 79: "Sensory and Vascular Organs. Otaria jubata" see Berjeau, 8: Plate 79

Plate 80: "Organs of Deglution \& Voice. Otaria jubata" see Berjeau, 8: Plate 80 
NEWTON

Volume 1 (1835)

Plate 6

subject: Lagotis cuvieri

description and notes: engraving; plate signed Newton del., Swaine Sc.; plate shows skeleton only

article: Bennett, E.T. "On the Chinchillidae, a family of herbivorous Rodentia, and on a new genus referrible [sic] to it." $1: 35-64$.

Plate 7

subject: Chinchilla lanigera

description and notes: engraving; plate signed Newton del., Swaine Sc.; plate shows skeleton only

article: Bennett, E.T. "On the Chinchillidae, a family of herbivorous Rodentia, and on a new genus referrible [sic] to it." $1: 35-64$. 
OWEN, Sir Richard (1804-1892)

\section{Volume 1 (1835)}

\section{Plate 8}

subject: Semnopithecus entellus

description and notes: lithograph; plate signed $\mathrm{K}$. Owen del., W. Wing lith.; printed by Hullmandel \& Walton; plate shows stomach only

article: Owen, Richard. "On the sacculated form of stomach as it exists in the genus

Semnopithecus, F. Cuv." 1:65-70.

Plate 9

subject: Semnopithecus entellus

description and notes: lithograph; plate signed R. Owen del., W. Wing lith.; printed by Hullmandel \& Walton; plate shows anatomical details of stomach

article: Owen, Richard. "On the sacculated form of stomach as it exists in the genus

Semnopithecus, F. Cuv." 1:65-70.

Plate 18

subject: Buceros cavatus

description and notes: lithograph; plate signed Owen del., G. Scharf lithog.; printed by C.

Hullmandel; plate shows anatomical details only article: Owen, Richard. "On the anatomy of the concave hornbill, Buceros cavatus, Lath." $1: 117-122$.

Plate 22: Terebratula

subject: Terebratula chilensis, Brod.;

Terebratula uva, Brod.; Terebratula

psittacea, Brug.; Terebratula sowerbii, King description and notes: engraving (partially

hand-colored); plate signed R. Owen \& G. Sowerby del., Zeitter sc.; plate shows anatomy of animals article: Owen, Kichard. "On the anatomy of the Brachiopoda of Cuvier, and more especially of the genera Terebratula and Orbicula." $1: 145-164$. 


\section{Plate 23: Orbicula \& Lingula}

subject: Orbicula cumingii, Brod.; Orbicula strigata, Brod.; Orbicula lamellosa, Brod.; Lingula audebardii, Brod.; Lingula semen, Brod.

description and notes: engraving (partially hand-colored); plate signed R. Owen \& G. Sowerby del., Zeitter sc.; plate shows anatomy of animals article: Owen, Richard. "On the anatomy of the Brachiopoda of Cuvier, and more especially of the genera Terebratula and Orbicula." $1: 145-164$.

Plate 30

subject: Calyptraea (Calypeopsis) byronensis; Clavagella lata

description and notes: engraving; plate signed R. Owen del., Zeitter sc.; figures show anatomy of species

article: Owen, Richard. "On the anatomy of the Calyptraeidae." 1:207-212.

Plate 31

subject: Siren lacertinal

description and notes: engraving; plate signed $\mathrm{R}$. Owen del., Zeitter sc.; plate shows details of heart anatomy

article: Owen, Richard. "On the structure of the heart in the Perennibranchiate Batrachia." $1: 213-220$.

Plate 33

subject: Ornithorhynchus paradoxus

description and notes: engraving; plate signed $\mathrm{R}$. Owen del., Zeitter sc.; plate shows details of anatomy

article: Owen, Richard. "On the young of the Ornithorhynchus paradoxus, Blum." 1:221-228.

Plate 41

subject: Trichina spiralis; Linguatula taenioides; Distoma clavatum; Taenia lamelligera

description and notes: engraving; plate signed R. Owen del., Zeitter sc.

article: Owen, Richard. "Description of a microscopic entozoon infesting the muscles of the human body." $1: 315-324$. [with] "Appendix." $1: 323 *$. 
Plate 48

subject: Simia troglodytes

description and notes: engraving; plate signed Owen del., J. Swaine sc.; plate shows skeletons of juvenile and adult chimpanzees

article: Owen, Richard. "On the osteology of the chimpanzee and orang utan." $1: 343-379$.

Plate 49

subject: Simia satyrus

description and notes: engraving; plate signed Owen del., J. Swaine sc.; plate shows skeletons of juvenile and adult orang utans

article: Owen, Richard. "On the osteology of the chimpanzee and orang utan." $1: 343-379$.

Plate 50

subject: Simia troglodytes; Simia satyrus

description and notes: engraving; plate signed Owen del., J. Swaine sc.; plate shows skeletons

article: Owen, Richard. 'On the osteology of the chimpanzee and orang utan." 1:343-379.

Plate 56

subject: Simia troglodytes; Simia satyrus

description and notes: lithograph; printed by $C$. Hullmandel; plate signed K. Owen del., G. Scharf lithog.; plate shows views of skulls

article: Owen, Richard. "On the osteology of the chimpanzee and orang utan." $1: 343-379$.

\section{Volume 2 (1841)}

Plate 21

subject: Cranchia scabra; Loligo laticeps;

Octopus semipalmatus; Argonauta hians;

Sepioteuthis; Rossia palpebrosa; Sepia officinalis

description and notes: engraving; plate signed R. Owen del., Zeitter sc.

article: Owen, Richard. "Descriptions of some new and rare Cephalopoda." 2:103-130. 
Volume 3 (1849)

Plate 31

subject: Apteryx australis

description and notes: engraving; plate signed R.O. \&W. Scharf, del., J. Basire, sc.; figure shown 4/7 natural size; shows superficial muscles article: Owen, Richard. "On the anatomy of the Apteryx australis, Shaw. Part II. (Myology.)" $3: 277-301$.

Plate 32

subject: Apteryx australis

description and notes: engraving; plate signed R.O. \& W. Scharf, del., J. Basire, sc.; figure shown

4/7 natural size; shows second layer of muscles article: Cwen, Kichard. "On the anatomy of the

Apteryx australis, Shaw. Part II. (Myology.)" 3:277-301.

Plate 33

subject: Apteryx australis

description and notes: engraving; plate signed R.O. \&W. Scharf, del., J. Basire, sc.; figure shown 4/7 natural size; shows deeper muscles of back and neck

article: Owen, Richard. "On the anatomy of the Apteryx australis, Shaw. Part II. (Myology.)" 3:277-301.

Plate 34

subject: Apteryx australis

description and notes: engraving; plate signed R.O. \& W. Scharf, del., J. Basire, sc.; figure shown $4 / 7$ natural size; shows second layer of muscles of back and neck

article: Owen, Richard. "On the anatomy of the

Apteryx australis, Shaw. Part II. (Myology.)" 3:277-301.

Plate 35

subject: Apteryx australis

description and notes: engraving; plate signed R.O. $\& W$. Scharf, del., J. Basire, sc.; figure shown 4/7 natural size; double-page folded plate; shows muscles of the species

article: Owen, Richard. "On the anatomy of the Apteryx australis, Shaw. Part II. (Myology.)" 3:277-301. 
Volume 4 (1862)

Plate 40: "Salivary Glands" subject: Dasypus sexcinctus; Dasypus peba; Myrmecophaga didactyla

description and notes: lithograph; printed by Day \& Haghe; plate signed K.O. delin., Lens Aldous, Zinc; double-page folded plate

article: Owen, [Professor]. "On the anatomy of the great anteater (Myrmecophaga jubata, Linn.)." 4:117-140.

Volume 6 (1869)

Plate 14

subject: Physeter simus; Physeter macrocephalus; Physeter breviceps

description and notes: lithograph; printed by M. \& $\mathrm{N}$. Hanhart; plate signed R. Owen, del. on Stone by J. Erxleben; shows views of skulls

article: Owen, [Professor]. "On some Indian Cetacea collected by Walter Elliot, Esq." 6:17-47.

\section{Volume 7 (1872)}

Plate 15

subject: Dinornis ingens

description and notes: lithograph; printer not given; plate signed R. Owen del., J. Erxleben lith.

article: Owen, [Professor]. "On Dinornis (Part XIV.): containing contributions to the craniology of the genus, with a description of the fossil cranium of Dasornis londinensis, Ow., from the London Clay of Sheppey." 7:123-150.

Plate 45

subject: Apteryx australis; Dinornis giganteus description and notes: lithograph; printed by $M$. \& N. Hanhart; plate signed R.0. delt., J. Smit lith.

article: Owen, [Professor]. "On Dinornis (Part XVI.): containing notices of the internal organs of some species, with a description of the brain and some nerves and muscles of the head of the Apteryx australis." 7:381-396. 
Plate 46

subject: Apteryx australis; Casuarius galeatus;

Dinornis ingens; Aptornis defossor;

Dinornis elephantopus

description and notes: lithograph; printed by M. \&

N. Hanhart; plate signed R.O. delt., J. Smit lith.

article: Uwen, [Professor]. "On Dinornis (Part XVI.): containing notices of the internal organs of some species, with a description of the brain and some nerves and muscles of the head of the Apteryx australis." $7: 381-396$.

Volume $\delta(1874)$

Plate 16

subject: Aptornis defossor; Ocydromus australis

description and notes: lithograph; printed by M. \&

$\mathrm{N}$. Hanhart; plate signed R. Owen del., J.

Erxleben lith.; shows articulated skeletons article: Owen, [Professor]. "On Dinornis (Part XVII.): containing a description of the sternum and pelvis, with an attempted restoration, of Aptornis defossor, Ow." 8:119-126.

Volume 9 (1877)

Plate 35: "Skull of Cnemiornis"

subject: Cnemiornis; Sereopsis

description and notes: lithograph; printed by Mintern Bros.; plate signed R.0. del., Griesbach lith.

article: Owen, [Professor]. "On Dinornis (Part $\left.X_{X}.\right)$ : containing a restoration of the skeleton of Cnemiornis calcitrans, Ow., with remarks on its affinities in the Lamellirostral group." 9:253-272.

Plate 36: "Vertebrae of Cnemiornis"

subject: Cnemiornis calcitrans; Sereopsis; Tachyeres brachypterus

description and notes: lithograph; printed by Mintern Bros.; plate signed R.0. del., Griesbach lith.

article: Owen, [Professor]. "On Dinornis (Part XX.): containing a restoration of the skeleton of Cnemiornis calcitrans, Cw., with remarks on its affinities in the Lamellirostral group." 9:253-272. 
Plate 37: "Sternum of Cnemiornis"

subject: Cnemiornis; Sereops is

description and notes: lithograph; printed by

Mintern bros.; plate signed K.O. del., Griesbaclı lith.

article: Owen, [Professor]. "On Dinornis (Part

XX.): containing a restoration of the skeleton

of Cnemiornis calcitrans, Ow., with remarks on

its affinities in the Lamellirostral group."

9:253-272.

Plate 38: "Humerus \& Ulna of Cnemiornis"

subject: Cnemiornis; Sereopsis; Tachyeres

brachypterus

description and notes: lithograph; printed by

Mintern Bros.; plate signed R.O. del., Griesbach lith.

article: Owen, [Professor]. "On Dinornis (Part

XX.): containing a restoration of the skeleton

of Cnemiornis calcitrans, Ow., with remarks on

its affinities in the Lamellirostral group."

9:253-272.

Plate 39: "Restored Skeleton of Cnemiornis, Restored

Skeleton of Cereopsis"

subject: Cnemiornis calcitrans; Sereopsis

description and notes: lithograph; printed by

Mintern Bros.; plate signed R.O. del., Griesbach lith.

article: Owen, [Professor]. "On Dinornis (Part

$\mathrm{XX}$.$) : containing a restoration of the skeleton$

of Cnemiornis calcitrans, Ow., with remarks on

its affinities in the Lamellirostral group."

9:253-272. 


$$
\text { P., C.M. }
$$

Volume 19 (1909-1910)

Plate 20

subject: Rousettus lanosus Thos.; Myosorex

blarina Thos.

description and notes: chromolithograph; printed by

Miles \& Co.; plate signed C.M.P.-F.E.J.; signed

with monogram "CMP"

article: Thomas, Oldfield and R.C. Wroughton.

"Ruwenzori Expedition reports. 17. Mammalia." $19: 481-528$.

Plate 21

subject: Mungos sanguineus proteus Thos.

description and notes: chromolithograph; printed by Miles \& Co.; plate signed Moorepark lith.; signed with monogram "CMP"

article: Thomas, Oldfield and R.C. Wroughton.

"Ruwenzori Expedition reports. 17. Mammalia." $19: 481-528$.

Plate 22

subject: Sciurus ruwenzorii Schwann; Funisciurus carruthersi Thos.

description and notes: chromolithograph; printed by Miles \& Co.; plate signed C.M.P.-F.E.J.; signed with monogram "CMP"

article: Thomas, Oldfield and R.C. Wroughton.

"Ruwenzori Expedition reports. 17. Mammalia." $19: 481-528$.

Plate 23

subject: Funisciurus antoniae Thos. \& Wr.;

Leggada bufo Thos.

description and notes: chromolithograph; printed by Miles \& Co.; Plate signed C.M.P.-F.E.J.; signed
with monogram "CMP"

article: Thomas, Oldfield and R.C. Wroughton.

"Ruwenzori Expedition reports. 17. Mammalia."

19:481-528. 


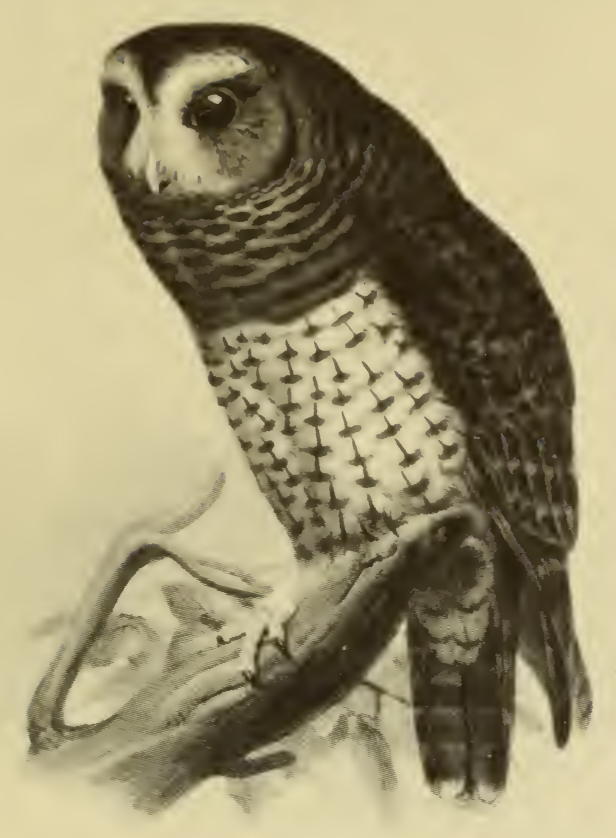

Syonium albitarse

(Wolf, 4: Plate 60)

AMNH Library Collections 



$$
\text { P., C.M. }
$$

Plate 24

subject: Arvicanthis macculus Thos. \& Wr.; Lophuromys woosnami Thos.

description and notes: chromolithograph; printed by

Miles \& Co.; plate signed Moorepark lith.;

signed with monogram "CNP"

article: Thomas, Oldfield and R.C. Wroughton.

"Kuwenzori txpedition reports. 17. Mammalia." $19: 481-528$. 
PARKER, M.P. [fl. 1880-1895]

Volume 11 (1885)

Plate 62: "Embryos of Crocodilia" see Parker, W.K., 11: Plate 62

Plate 66: "Skull of Crocodilia" see Parker, W.K., 11: Plate 66

Plate 67: "Skull of Crocodilia" subject: Alligator mississipensis

description and notes: hand-colored lithograph; printed by West, Newman \& Co.; plate signed M.P.P. del. ad nat.

article: Parker, W.K. "On the structure and development of the skull in the Crocodilia." $11: 263-310$.

Plate 70: "Skull of Crocodilia" see Parker, W.K., 11: Plate 70

Plate 71: "Skull of Crocodilia" subject: Crocodilus palustris description and notes: hand-colored lithograph; printed by West, Newman \& Co.; plate signed M.P.P. del. ad nat.

article: Parker, W.K. "On the structure and development of the skull in the Crocodilia." $11: 263-310$.

Volume 14 (1898)

Plate 28: "Skull of Lepidosiren" subject: Lepidosiren

description and notes: chromolithograph; printed by West, Newman

article: Bridge, W.T. "On the morphology of the skull in the Paraguayan Lepidosiren and in other Dipnoids." 14:325-376. 
Plate 29: "Skull of Lepidosiren" subject: Lepidosiren; Ceratodus fosteri

description and notes: chromolithograph; printed by West, Newman

article: Bridge, W.T. "On the morphology of the skull in the Paraguayan Lepidosiren and in other Dipnoids." 14:325-376. 
Volume 11 (1885)

Plate 10: "Intestinal Spiral Valves of Raia" subject: Raia; Raia maculata [male and female]; Raia batis [female and male] description and notes: lithograph; printed by Hanhart; plate signed T.J.P. del. ad nat., M.P. Parker lith.

article: Parker, T. Jeffery. "On the intestinal spiral valve in the genus Raia." 11:49-61.

Plate 11: "Intestinal Spiral Valves of Raia" subject: Scyllium canicula [female]; Chimaera monstrosa; Zygaena malleus

description and notes: lithograph; printed by Hanhart; plate signed T.J.P. del. ad nat., M.P. Parker lith.

article: Parker, T. Jeffery. "On the intestinal spiral valve in the genus Raia." 11:49-61.

Volume 12 (1890)

Plate 2

subject: Regalecus argenteus

description and notes: hand-colored lithograph; printed by West, Newman \& Co.; plate signed

T.J.P. ad nat. del., Parker \& Coward lith. article: Parker, T. Jeffery. "Studies in

New-Zealand ichthyology. I. On the skeleton of Regalecus argenteus." 12:5-33.

Plate 3

subject: Regalecus argenteus

description and notes: lithograph; printed by West, Newman \& Co.; plate signed T.J.P. ad nat. delt., Parker \& Coward lith.; figures shown $1 / 10$

natural size

article: Parker, T. Jeffery. "Studies in

New-Zealand ichthyology. I. On the skeleton of Regalecus argenteus." 12:5-33. 
Plate 4

subject: Regalecus argenteus

description and notes: hand-colored lithograph; printed by West, Newman \& Co.; plate signed

T.J.P. ad nat. delt., Parker \& Coward lith.

article: Harker, T. Jeffery. "Studies in

New-Zealand ichthyology. I. On the skeleton of

Regalecus argenteus." $12: 5-33$.

Plate 5

subject: Regalecus argenteus

description and notes: hand-colored lithograph; printed by West, Newman \& Co.; plate signed

T.J.P. ad nat. delt., Parker \& Coward lith. article: Parker, T. Jeffery. "Studies in

New-Zealand ichthyology. I. On the skeleton of Regalecus argenteus." 12:5-33.

Plate 6

subject: Regalecus argenteus

description and notes: hand-colored lithograph; printed by West, Newman \& Co.; plate signed

T.J.P. ad nat. del., Parker \& Coward lith.

article: Parker, T. Jeffery. "Studies in

New-Zealand ichthyology. I. On the skeleton of

Regalecus argenteus." $12: 5-33$.

Plate 49

subject: Ziphius

description and notes: hand-colored lithograph;

printed by West, Newman \& Co.; plate signed

T.J.P. \& J.H.S. ad nat. delt., Parker \& Coward

lith.

article: Scott, John H. and T. Jeffery Parker. "On a species of Ziphius recently obtained near

Dunedin." 12:241-248.

Plate 50

see Scott, 12: Plate 50

\section{Volume 13 (1895)}

Plate 57

subject: Emeus sp. alpha

description and notes: chromolithograph; printed by

West, Newman; plate signed T.J.P. delt., M.P.

Parker chromo.

article: Parker, T. Jeffrey. "On the cranial osteology, classification, and phylogeny of the Dinornithidae." 13:373-43i. 
Plate 59

subject: Emeus sp. alpha; Anomolopteryx didiformis

description and notes: chromolithograph; printed by West, Newman; plate signed T.J.P. delt., M.F. Parker chromo.

article: Parker, I. Jeffrey. "On the cranial osteology, classification, and phylogeny of the Dinornithidae." 13:373-431.

Plate 61: "Outlines of Crania of Dinornithidae" subject: Dinornis torosus Hutt; Anomolopteryx didiformis Ow.; Pachyornis elephantopus; Pachyornis sp. alpha; Mesopteryx casuarina Ow.; Mesopteryx sp. alpha; Mesopteryx sp. beta; Mesopteryx sp. lambda; Emeus sp. alpha; Emeus sp. beta; Emeus crassus Ow.; Emeus sp. lambda

description and notes: hand-colored lithograph; printed by West, Newman; plate signed T.J.P. delt., M.P. Farker lith.

article: Parker, T. Jeffrey. "On the cranial osteology, classification, and phylogeny of the Dinornithidae." 13:373-431.

Plate 62: "Outlines of Crania of Dinornithidae, Parts of Skull of Various Ratitae" see Hamilton, 13: Plate 62 


\section{PARKER, William Kitchen (1823-1890)}

\section{Volume $5(1866)$}

Plate 34

subject: Hemipodius sp.?; Chamaeopelia passernia; Tinamus robustus

description and notes: lithograph; printed by $M . \&$ N. Hanhart; plate signed W.K. Parker delt., J. Erxleben 1 ith.

article: Parker, W.K. "On the osteology of gallinaceous birds and tinamous." 5:149-241.

Plate 35

subject: Hemipodius varius

description and notes: lithograph; printed by M. \& N. Hanhart; plate signed W.K. Parker delt., J. Erxleben lith.

article: Parker, W.K. "On the osteology of gallinaceous birds and tinamous." 5:149-24l.

Plate 36

subject: Syrrhaptes paradoxus; Lagopus scoticus description and notes: lithograph; printed by $M$. \& N. Hanhart; plate signed W.K. Parker delt., J. Erxleben lith.

article: Parker, W.K. "On the osteology of gallinaceous birds and tinamous." 5:149-241.

Plate 37

subject: Vanellus cristatus; Columba livia

description and notes: 1ithograph; printed by M. \& N. Hanhart; plate signed W.K. Parker delt., J. Erxleben lith.

article: Parker, W.K. "On the osteology of gallinaceous birds and tinamous." 5:149-241.

Plate 42

subject: Rhea americana

description and notes: lithograph; printed by M. \& N. Hanhart; plate signed W.K. Parker delt., J. Erxleben lith.; figure shown natural size article: Parker, W.K. "On the osteology of gallinaceous birds and tinamous." 5:149-241. 
Volume 9 (1877)

Plate 54

subject: Turnix rostratus; Hemipodius varius

description and notes: hand-colored lithograph; printed by $W$. West \& Co.; plate signed W.K.P. del. ad nat., G. West lith.

article: Yarker, W.K. "On aegithognathous birds

(Part I.)." 9:289-352.

Plate 55

subject: Corvus frugilegus; Corvus corone;

Fregilus graculus; Ruticilla phoenicurus [young]

description and notes: hand-colored lithograph; printed by W. West \& Co.; plate signed W.K.P. del. ad nat., G. West lith.

article: Parker, W.K. "On aegithognathous birds (Part I.)." 9:289-352.

Plate 56

subject: Menura superba [female]; Pitta melanocephala; Grallaria squamigera

description and notes: hand-colored lithograph; printed by W. West \& Co.; plate signed W.K.P. del. ad nat., G. West lith.

article: Parker, W.K. "On aegithognathous birds (Part I.)." 9:289-352.

Plate 57

subject: Pipra auricapilla; Pachyrhamphus;

Thamnophilus doliatus

description and notes: hand-colored lithograph; printed by W. West \& Co.; plate signed W.K.P. del. ad nat., G. West lith.

article: Parker, W.K. "On aegithognathous birds

(Part I.)." 9:289-352.

Plate 58

subject: Artamus leucorhinus; Hyloterpe

sulfuriventer; Dicrurus leucops; Enodes

erythrophrys; Trichastoma celebense

description and notes: hand-colored lithograph;

printed by W. West \& Co.; plate signed W.K.P. del. ad nat., G. West 1 ith.

article: Parker, W.K. "On aegithognathous birds

(Part I.)." 9́:289-352. 
Plate 59

subject: Dendrocolaptes albicollis; Anaeretes parulus; Synallaxis flavigularis;

Muscisaxicola mentalis

description and notes: hand-colored lithograph; printed by W. West \& Co.; plate signed W.K.P. del. ad nat., G. West lith.

article: Parker, W.K. "On aegithognathous birds (Part I.)." 9:289-352.

Plate 60

subject: Homorus unicolor; Gymnorhina tibicen;

Petroica monticola; Petroica bicolor

description and notes: hand-colored lithograph;

printed by $W$. West \& Co.; plate signed W.K.P.

del. ad nat., G. West lith.

article: Parker, W.K. "On aegithognathous birds (Part I.)." $\xi: 289-352$.

Plate 61

subject: Elainea; Lanius collurio;

Pachycephala fusca(?)

description and notes: hand-colored lithograph;

printed by $W$. West \& Co.; plate signed W.K.P.

del. ad nat., G. West lith.

article: Parker, W.K. "On aegithognathous birds (Part I.)." $9: 289-352$.

Plate 62

subject: Lalage leucopygialis; Paradisea

papuana; Chasmorhynchus nudicollis

description and notes: hand-colored lithograph;

printed by W. West \& Co.; plate signed W.K.P.

del. ad nat., G. West lith.

article: Parker, W.K. "On aegithognathous birds (Part I.)." 9:289-352.

Volume 10 (1879)

Plate 34

subject: Scyllium canicula

description and notes: hand-colored lithograph;

printed by W. West; plate signed W.K.P. del. ad nat., G. West lith.

article: Parker, W.K. "On the structure and development of the skull in sharks and skates." $10: 189-234$. 
Plate 35

subject: Pristiurus; Scyllium canicula

description and notes: hand-colored lithograph; printed by W. West; plate signed W.K.F. del. ad nat., G. West lith.

article: Parker, W.K. "On the structure and development of the skull in sharks and skates." $10: 189-234$.

Plate 36

subject: Scyllium canicula

description and notes: hand-colored lithograph; printed by W. West; plate signed W.K.P. del. ad nat., G. West lith.

article: Parker, W.K. "Cn the structure and development of the skull in sharks and skates." $10: 189-234$.

Plate 37

subject: Scyllium canicula

description and notes: hand-colored lithograph; printed by W. West; plate signed W.K.P. del. ad nat., G. West lith.

article: Parker, W.K. "On the structure and development of the skull in sharks and skates." $10: 189-234$.

Plate 38

subject: Scyllium canicula

description and notes: hand-colored lithograph; printed by W. West; plate signed W.K.P. del. ad nat., G. West lith.

article: Parker, W.K. "On the structure and development of the skull in sharks and skates." $10: 189-234$.

Plate 39

subject: Raia maculata; Scyllium canicula

description and notes: hand-colored lithograph; printed by W. West; plate signed W.K.P. del. ad nat., G. West lith.

article: Parker, W.K. "On the structure and development of the skull in sharks and skates." $10: 189-234$.

Plate 40

subject: Raia maculata; Pristiurus

description and notes: hand-colored lithograph; printed by $W$. West; plate signed W.K.P. del. ad nat., G. West lith.

article: Parker, W.K. "On the structure and development of the skull in sharks and skates." $10: 189-234$. 
Plate 41

subject: Raia clavata

description and notes: hand-colored lithograph; printed by W. West; plate signed W.K.P. del. ad nat., G. West lith.

article: Parker, W.K. "On the structure and development of the skull in sharks and skates." $10: 189-234$.

Plate 42

subject: Raia clavata; Scyllium canicula

description and notes: hand-colored lithograph; printed by W. West; plate signed W.K.P. del. ad nat., G. West lith.

article: Parker, W.K. "On the structure and development of the skull in sharks and skates." $10: 189-234$.

Plate 46: "Aegithognathae"

subject: Tanagra cyanoptera; Euphonia violacea;

Stephanophorus leucocephalus; Pyranga rubra;

Prionochilus aureolimbatus; Phytotoma rara

description and notes: hand-colored lithograph;

printed by $W$. West; plate signed W.K.P. del. ad nat., C. Berjeau lith.

article: Parker, W.K. "On the skull of the aegithognathous birds. Part II." 10:251-314.

Plate 47: "Aegithognathae"

subject: Acanthorhynchus tenuirostris;

Ptilotis; Sericornis humilis(?); Sittella

description and notes: hand-colored lithograph;

printed by W. West; plate signed W.K.P. del. ad nat., C. Berjeau lith.

article: Parker, W.K. "On the skull of the aegithognathous birds. Part II." 10:251-314.

Plate 48: "Aegithognathae"

subject: Dendraeca pennsylvanica; Mniotilta

varia; Geothlypis trichas; Chlorophanes atricapilla; Vireosylvia olivacea;

Cardinalis virginiana

description and notes: hand-colored lithograph;

printed by W. West; plate signed W.K.P. del. ad nat., C. Berjeau lith.

article: Parker, W.K. "On the skull of the aegithognathous birds. Part II." 10:251-314. 
Plate 49: "Aegithognathae"

subject: Icterus sp.?; Icterus vulgaris; Sturnella militaris; Emberiza miliaria;

Emberiza citrinella; Plectrophanes nivalis; Phrygilus fruticeti

description and notes: hand-colored lithograph; printed by $W$. West; plate signed W.K.P. del. ad nat., C. Berjeau lith.

article: Parker, W.K. "On the skull of the aegithognathous birds. Part II." 10:251-314.

Plate 50: "Aegithognathae"

subject: Coccothraustes vulgaris; Estrelda astrild; Linaria chloris; Alauda arvensis

description and notes: hand-colored lithograph; printed by $W$. West; plate signed W.K.P. del. ad nat., C. Berjeau lith.

article: Parker, W.K. "On the skull of the aegithognathous birds. Part II." 10:251-314.

Plate 51: "Aegithognathae"

subject: Parus ater; Parus major; Suthora bulomachus; Cyclorhis; Sitta europaea; Panurus biarmicus

description and notes: hand-colored lithograph; printed by W. West; plate signed W.K.P. del. ad nat., C. Berjeau lith.

article: Parker, W.K. "On the skull of the aegithognathous birds. Part II." 10:251-314.

Plate 52: "Aegithognathae"

subject: Cypselus apus; Chelidon urbica;

Oriolus galbula; Motacilla yarrelli;

Budytes rayi; Muscicapa grisola; Liothrix;

Pratincola rubetra

description and notes: hand-colored lithograph; printed by W. West; plate signed W.K.P. del. ad nat., C. Berjeau lith.

article: Parker, W.K. "On the skull of the aegithognathous birds. Part II." 10:251-314.

Plate 53: "Aegithognathae"

subject: Nectarophila grayi; Anthreptes malaccensis

description and notes: hand-colored lithograph; printed by $W$. West; plate signed W.K.P. del. ad nat., C. Berjeau lith.

article: Parker, W.K. "On the skull of the aegithognathous birds. Part II." 10:251-314. 
Plate 54: "Aegithognathae"

subject: Thinocorus rumicivorus; Anthropoides stanleyanus; Eurypyga helias

description and notes: hand-colored lithograph; printed by W. West; plate signed W.K.P. del. ad nat., C. Berjeau lith.

article: Parker, W.K. "On the skull of the aegithognathous birds. Part II." 10:251-314.

\section{Volume 11 (1885)}

Plate 15: "Skulls of Chameleons" subject: Chamaeleo vulgaris

description and notes: lithograph; printed by west, Newman \& Co.; plate signed W.K.P. del. ad nat., G. West Jr. lith.; figures shown $131 / 3$ times natural size

article: Parker, W.K. "On the structure of the skull in the chameleons." 11:77-105.

Plate 16: "Skulls of Chameleons"

subject: Chamaeleo vulgaris [female]

description and notes: lithograph; printed by West, Newman \& Co.; plate signed W.K.P. del. ad nat., G. West Jr. Iith.

article: Parker, W.K. "On the structure of the skul1 in the chameleons." 11:77-105.

Plate 17: "Skulls of Chameleons" subject: Chamaeleo vulgaris [male]

description and notes: lithograph; printed by west, Newman \& Co.; plate signed W.K.P. del. ad nat., G. West Jr. lith.; figures shown $33 / 4$ times natural size

article: Parker, W.K. "On the structure of the skul1 in the chameleons." 11:77-105.

Plate 18: "Skulls of Chameleons" subject: Chamaeleo vulgaris [male]

description and notes: lithograph; printed by West, Newman \& Co.; plate signed W.K.P. del. ad nat., M.P.P. lith.; figures shown $33 / 4$ times natural size

article: Parker, W.K. "On the structure of the skul1 in the chameleons." 11:77-105. 
Plate 19: "Skulls of Chameleons"

subject: Chamaeleo pumilus [female]

description and notes: lithograph; printed by West, Newman \& Co.; plate signed W.K.P. del. ad nat., G. West Jr. 1ith.; figures shown 6 times natural size

article: Parker, W.K. "On the structure of the skull in the chameleons." 11:77-105.

Plate 36

subject: Sieboldia maxima

description and notes: hand-colored lithograph; printed by West, Newman \& Co.; plate signed W.K.P. del. ad nat., M.P. Parker litho. article: Parker, W.K. "On the structure and development of the skull in the Urodeles." $11: 171-214$.

Plate 37

subject: Sieboldia maxima

description and notes: hand-colored lithograph; printed by West, Newman \& Co.; plate signed W.K.P. del. ad nat., M.P. Parker lith.

article: Parker, W.K. "On the structure and development of the skull in the Urodeles." $11: 171-214$.

Plate 38: "Menopoma and Siren

subject: Menopoma alleghaniensis; Siren lacertina

description and notes: hand-colored lithograph; printed by West, Newman \& Co.; plate signed W.K.P. del. ad nat., M.P. Parker lith. article: Parker, W.K. "On the structure and development of the skull in the Urodeles." $11: 171-214$.

Plate 39: "Siren and Menopoma subject: Siren lacertina; Menopoma alleghaniensis

description and notes: hand-colored lithograph; printed by West, Newman \& Co.; plate signed W.K.P. del. ad nat., M.P. Parker lith.

article: Parker, W.K. "On the structure and development of the skull in the Urodeles." $11: 171-214$.

Plate 40: "Lissotriton and Triton subject: Lissotriton punctatus; Triton cristatus description and notes: hand-colored lithograph; printed by West, Newman \& Co.; plate signed W.K.P. del. ad nat., Edwin Wilson lith. article: Parker, W.K. "On the structure and development of the skull in the Urodeles." $11: 171-214$. 
Plate 41

subject: Triton cristatus

description and notes: hand-colored lithograph; printed by West, Newman \& Co.; plate signed W.K.P. del. ad nat., Edwin Wilson lith.

article: Parker, W.K. "On the structure and development of the skull in the Urodeles." $11: 171-214$.

Plate 62: "Embryos of Crocodilia" subject: Alligator mississipensis Daudin; Crocodilus palustris Lesson

description and notes: lithograph; printed by West, Newman \& Co.; plate signed W.K.P. \& M.P.P. del. ad nat. et lith.

article: Parker, W.K. "On the structure and development of the skull in the Crocodilia." $11: 263-310$.

Plate 63: "Skull of Crocodilia"

subject: Alligator mississipensis

description and notes: lithograph; printed by West, Newman \& Co.; plate signed W.K.P. del. ad nat., M.P.P. lith.

article: Parker, W.K. "On the structure and development of the skull in the Crocodilia." $11: 263-310$.

Plate 64: "Skull of Crocodilia"

subject: Alligator mississipensis; Crocodilus palustris

description and notes: lithograph; printed by West, Newman \& Co.; plate signed W.K.P. del. ad nat., M.P.P. lith.

article: Parker, W.K. "On the structure and development of the skull in the Crocodilia." $11: 263-310$.

Plate 65: "Skull of Crocodilia"

subject: Crocodilus palustris; Alligator mississipensis

description and notes: hand-colored lithograph; printed by West, Newman \& Co.; plate signed W.K.P. del ad nat., M.P.P. lith. article: Parker, W.K. "On the structure and development of the skull in the Crocodilia." $11: 263-310$. 
Plate 66: "Skull of Crocodilia"

subject: Alligator mississipens is

description and notes: hand-colored lithograph; printed by West, Newman \& Co.; plate signed

W.K.P. \& M.P.P. del. ad nat.

article: Parker, W.K. "On the structure and development of the skull in the Crocodilia." $11: 263-310$.

Plate 68: "Skull of Crocodilia"

subject: Alligator mississipensis; Crocodilus palustris

description and notes: hand-colored lithograph; printed by West, Newman \& Co.; plate signed W.K.P. del. ad nat., M.P. Farker lith.

article: Parker, W.K. "On the structure and development of the skull in the Crocodilia." $11: 263-310$.

Plate 69: "Skull of Crocodilia"

subject: Crocodilus palustris

description and notes: hand-colored lithograph; printed by West, Newman \& Co.; plate signed W.K.P. del ad nat., M.P.P. lith.

article: Parker, W.K. "On the structure and development of the skull in the Crocodilia." $11: 263-310$.

Plate 70: "Skull of Crocodilia" subject: Crocodilus palustris

description and notes: hand-colored lithograph; printed by West, Newman \& Co.; plate signed W.K.P. \& M.P.P. del. ad nat.

article: Parker, W.K. "On the structure and development of the skull in the Crocodilia." $11: 263-310$.

Volume 13 (1895)

Plate 7: "Morphology of Opisthocomus" subject: Opisthocomus cristatus

description and notes: lithograph; printed by West, Newman; plate signed W.K.P. del ad nat., M.P. Parker lith.; figure shown $41 / 2$ times natural size

article: Parker, W.K. "On the morphology of a reptilian bird, Opisthocomus cristatus." 13:43-85. 
Plate 8: "Morphology of Opisthocomus" subject: Opisthocomus cristatus

description and notes: lithograph; printed by West, Newman; plate signed W.K.P. del. ad nat., M.I'. Parker lith.

article: Parker, W.K. "On the morphology of a reptilian bird, Opisthocomus cristatus." $13: 43-85$.

Plate 9: "Morphology of Opisthocomus" subject: Opisthocomus cristatus

description and notes: lithograph; printed by West, Newman; plate signed W.K.P. del. ad mat. [sic], M.P. Parker lith.

article: Parker, W.K. "On the morphology of a reptilian bird, Opisthocomus cristatus." $13: 43-85$.

Plate 10: "Morphology of Opisthocomus" subject: Opisthocomus cristatus description and notes: lithograph; printed by West, Newman; plate signed W.K.P. del. ad nat., M.P. Parker lith.

article: Parker, W.K. "On the morphology of a reptilian bird, Opisthocomus cristatus." $13: 43-85$. 


\section{Volume 17 (1903-1906)}

Plate 1: "Species of Arhopala and Allied Genera" subject: Mahathala hainana [female]; Iraota lazarena [female]; Surendra amisena [male and female]; Surendra amisena blue [female]; Surendra vivarna [male]; Arhopala viola [male]; Arhopala dohertyi [male]; Arhopala hercules var. herculina [male]; Arhopala kiriwinii [male]; Arhopala eupolis [male]; Arhopala padus [male]; Arhopala padus blue [female]; Arhopala eridanus [male]; Arhopala tephlis [male]; Arhopala bazaloides [male]; Arhopala wildei [male and femalej; Arhopala sangira [male]; Arhopala helius [male]; Arhopala helius var. anthelius [male]; Arhopala myrtha [male]; Arhopala mindanensis [male]; Arhopala myrtale [male]; Arhopala quercoides [male]; Arhopala phaenops [male]; Arhopala ijauensis [male]; Arhopala brookei [male]; Arhopala pseudomuta [male]

description and notes: chromolithograph; printed by Mintern Bros.; plate signed W. Purkiss del. et chromo.

article: Bethune-Baker, George T. "A revision of the Amblypodia group of butterflies of the family Lycaenidae." 17:1-164. 
Plate 2: "Species of Arhopala and Allied Genera"

subject: Arhopala vihara [male]; Arhopala malayica [male]; Arhopala nicévillei [male]; Arhopala nobilis [male and female]; Arhopala moolaiana [male]; Arhopala amphimuta [male]; Arhopala inornata [male]; Arhopala epimuta [male]; Arhopala agesilaus [male]; Arhopala catori [male]; Arhopala davaoana [male]; Arhopala gunongensis [male]; Arhopala brahma [male]; Arhopala hypomuta [male]; Arhopala oberthuri [male]; Arhopala adonias [male]; Arhopala irregularis [female]; Arhopala eumolphus [male and female]; Arhopala staudingeri [male]; Arhopala horsfieldi [male]; Arhopala basiviridis [male]; Arhopala kuhni [male and female]; Arhopala morphina [male]

description and notes: chromolithograph; printed by Mintern Bros.; plate signed W. Purkiss del. et chromo.

article: Bethune-Baker, George T. "A revision of the Amblypodia group of butterflies of the family Lycaenidae." 17:1-164.

Plate 3: "Species of Arhopala and Allied Genera" subject: Arhopala chinensis [male]; Arhopala corinda [male]; Arhopala aenotria [male]; Arhopala aedias [male]; Arhopala barami [male]; Arhopala anamuta [male]; Arhopala allata [male]; Arhopala atrax [male]; Arhopala hewitsoni [male]; Arhopala japonica [male]; Arhopala perissa [male]; Arhopala tounguva [male]; Arhopala asopia [male]; Arhopala acron [male]; Arhopala admete var. waigeoensis [male]; Arhopala epimete [male]; Arhopala acetes [male]; Arhopala anunda [male]; Arhopala anunda var. [male]; Arhopala anunda pale blue var. [female]; Arhopala aexone [male]; Arhopala auxesia [male]; Arhopala ariel [male]; Arhopala buddha [male]; Arhopala canulia [male]; Arhopala argesias [male]; Arhopala hesba [male]; Arhopala viola [female]; Arhopala viola var. [female]; Arhopala ammonides [male]

description and notes: chromolithograph; printed by Mintern Bros.; plate signed W. Purkiss del. et chromo.

article: Bethune-Baker, George T. "A revision of the Amblypodia group of butterflies of the family Lycaenidae." $17: 1-164$. 
Plate 4: "Genitalia of [male] Arhopala and Allied Genera"

subject: Surendra amisena; Iraota timoleon; Amblypodia narada; Mahathala ameria; Thaduka multicaudata; Arhopala hercules; Arhopala philander; Arhopala meander; Arhopala amytis; Arhopala centaurus; Arhopala amantes; Arhopala padus; Arhopala eridanus; Arhopala tephlis; Arhopala bazaloides; Arhopala annulata; Arhopala theba; Arhopala anthore; Arhopala alitaeus; Arhopala dohertyi; Arhopala japonica; Arhopala paramuta; Arhopala paraganesa; Arhopala ganesa; Arhopala andamanica description and notes: lithograph; printed by Mintern Bros.

article: Bethune-Baker, George T. "A revision of the Amblypodia group of butterflies of the family Lycaenidae." 16:1-164.

\section{Plate 5: "Genitalia of [male] Arhopala and Allied Genera"}

subject: Arhopala alce; Arhopala anunda; Arhopala aroa; Arhopala elopura; Arhopala atosia; Arhopala epimuta; Arhopala agesilaus; Arhopala catori; Arhopala agesias; Arhopala moorei; Arhopala deva; Arhopala metamuta; Arhopala muta; Arhopala eumolphus; Arhopala basiviridis; Arhopala diardi; Arhopala apidanus; Arhopala adriana; Arhopale chinensis; Arhopala singla; Arhopala aenea; Arhopala rama; Arhopala hewitsoni; Arhopala alemon; Arhopala dodonea

description and notes: lithograph; printed by Mintern Bros.

article: Bethune-Baker, George T. "A revision of the Amblypodia group of butterflies of the family Lycaenidae." 16:1-164. 
RHODES, M.

Volume $20(1912-1915)$

Plate 36

subject: Iridia diaphana

description and notes: chromolithograph; printer

not noted on plate; plate signed $M$. Rhodes del. ad nat.

article: Heron-Allen, Edward. "The Foraminifera of the Kerimba Archipelago (Portuguese East

Africa.) Part I." 20:363-390.

Plate 37

subject: Nouria polymorphinoides; Nouria harrisii; Nouria compressa

description and notes: chromolithograph; printer not noted on plate; plate signed $M$. Rhodes del. ad nat.

article: Heron-Allen, Edward. "The Foraminifera of the Kerimba Archipelago (Portuguese East

Africa.) Part I." 20:363-390. 
RICHTER, Henry Constantine [fl. 1840/1870s]

\section{Volume 3 (1849)}

Plate 57

subject: Apteryx owenii

description and notes: hand-colored lithograph; printed by Hullmandel \& Walton

article: Gould, John. "On a new species of the genus Apteryx." 3:379-380. 


\section{ROBINSON, Edward William (1835-1877)}

\section{Volume 6 (1869)}

\section{Plate 16}

subject: Didus ineptus description and notes: lithograph; printed by $W$. West

article: Owen, [Professor]. "On the osteology of the dodo (Didus ineptus, Linn.)." 6:49-85.

Plate 18 subject: Didus ineptus

description and notes: lithograph; printed by $W$. West

article: Owen, [Professor]. "On the osteology of the dodo (Didus ineptus, Linn.)." 6:49-85. 
ROBINSON, F.

\section{Volume 5 (1866)}

Plate 10

subject: Troglodytes gorilla; Homo

description and notes: lithograph; printed by M. \&

N. Hanhart; plate signed From Nature on Stone by

F. Robinson; folded plate

article: Owen, [Professor]. "Osteological

contributions to the natural history of the anthropoid apes. No. VII. Comparison of the bones of the limbs of the Troglodytes gorilla, Troglodytes niger, and of different varieties of the human race; and on the general characters of the skeleton of the gorilla." 5:1-31.

Plate 11

subject: Homo; Troglodytes gorilla

description and notes: lithograph; printed by $M$. \&

N. Hanhart; plate signed From Nature on Stone by

F. Robinson; folded plate

article: Owen, [Professor]. "Osteological

contributions to the natural history of the anthropoid apes. No. VII. Comparison of the bones of the limbs of the Troglodytes gorilla, Troglodytes niger, and of different varieties of the human race; and on the general characters of the skeleton of the gorilla." 5:1-31.

Plate 46

subject: Troglodytes gorilla

description and notes: lithograph; printed by $W$. West

article: Owen, [Professor]. "Contributions to the natural history of the anthropoid apes. No. VIII. On the external characters of the gorilla (Troglodytes gorilla, Sav.)." 5:243-284.

Plate 48

subject: Troglodytes gorilla

description and notes: lithograph; printed by $W$. West

article: Owen, [Professor]. "Contributions to the natural history of the anthropoid apes. No. VIII. On the external characters of the gorilla (Troglodytes gorilla, Sav.)." 5:243-284. 
ROBSON, Guy Coburn (1888-1945)

Volume 20 (1912-1915)

Plate 32

subject: Papuina lituus; Antinous anthropophagorum; Chronos sublimis

description and notes: lithograph; printer not noted on plate; plate signed Robson del., J. Green lith.

article: Robson, Guy C. "Report on the Mollusca collected by the British Ornithologists' Union Expedition and the Wollaston Expedition in Dutch New Guinea." 20:287-306.

Plate 33

subject: Papuina wollastoni; Antinous anthropoophagorum; Chronos sublimis; Papuina lituus

description and notes: lithograph; printer not noted on plate; plate signed Kobson \& Green del., J. Green lith.

article: Robson, Guy C. "Report on the Mollusca collected by the British Ornithologists' Union Expedition and the Wollaston Expedition in Dutch New Guinea." 20:287-306. 
ROWE, W.M.

see Howe, W.M. 


$$
\text { RÜPPELL, Edward (1794-1884) }
$$

\section{Volume 2 (1841)}

\section{Plate 15}

subject: Histiophorus immaculatus

description and notes: engraving; plate signed E. Ruppell delt., J. Swaine Sc.

article: Rüppell, M.E. "Mémoire sur une nouvelle espèce de poisson du genre Histiophore, de la Mer Rouge." 2:71-74. 
SCHARF, George (1788-1860)

Volume 1 (1835)

Plate 51

subject: Simia troglodytes

description and notes: lithograph; printed by $C$. Hullmandel; plate signed Lithographed from

Nature by G. Scharf; plate gives view of skull article: Owen, Richard. 'On the osteology of the chimpanzee and orang utan." 1:343-379.

Plate 52

subject: Simia troglodytes

description and notes: lithograph; printed by $C$. Hullmandel; plate signed Lithographed from

Nature by G. Scharf; plate gives view of skull article: Owen, Richard. "On the osteology of the chimpanzee and orang utan." 1:343-379.

Plate 53

subject: Simia satyrus

description and notes: lithograph; printed by $C$. Hullmandel; plate signed G. Scharf del. et lith.; plate gives view of skull

article: Owen, Richard. "On the osteology of the chimpanzee and orang utan." 1:343-379.

Plate 54

subject: Simia satyrus

description and notes: lithograph; printed by $C$. Hullmandel; plate signed Lithographed from Nature by G. Scharf; plate gives view of skull article: Owen, Richard. "On the osteology of the chimpanzee and orang utan." 1:343-379.

\section{Plate 55}

subject: Simia troglodytes; Simia satyrus

description and notes: lithograph; printed by $C$. Hullmandel; plate signed Lithographed from Nature by G. Scharf; plate gives view of skulls article: Owen, Richard. "On the osteology of the chimpanzee and orang utan." 1:343-379. 
Plate 57: "Side View of the Skull of a human Idiot" subject: Homo sapiens

description and notes: lithograph; printed by C.

hullmandel; plate signed Lithographed from

Nature by G. Scharf; plate gives view of skull

article: Owen, Richard. "On the osteology of the

chimpanzee and orang utan." $1: 343-379$.

Plate 58: "Base of the Skull of a human Idiot" subject: Homo sapiens

description and notes: lithograph; printed by $C$.

hullmandel; plate signed Lithographed from

Nature by G. Scharf; plate gives view of skull article: Owen, Richard. "On the osteology of the chimpanzee and orang utan." 1:343-379.

\section{Volume 2 (1841)}

\section{Plate 30: "Simia wurmbii (immature)"} subject: Simia wurmbii

description and notes: lithograph; printed by $C$.

Hullmandel; plate signed G. Scharf del. et

lithog.; gives views of skull

article: Owen, Richard. "Osteological contributions to the natural history of the orang utans

(Simia, Erxleben)." 2:165-172.

Plate 31

\section{subject: Simia wurmbii}

description and notes: lithograph; printed by $C$.

Hullmandel; plate signed G. Scharf del. et

lith.; gives view of skull

article: Owen, Richard. "Osteological contributions to the natural history of the orang utans

(Simia, Erxleben)." 2:165-172.

Plate 32

\section{subject: Simia wurmbii}

description and notes: lithograph; printed by $C$.

Hullmandel; plate signed G. Scharf del. et

lith.; gives view of base of skull

article: Owen, Richard. "Osteological contributions

to the natural history of the orang utans

(Simia, Erxleben)." 2:165-172.

Plate 33

subject: Simia morio

description and notes: lithograph; printed by $C$.

Hullmandel; plate signed G. Scharf del. et

lithog.; gives views of skull

article: Owen, Richard. "Osteological contributions to the natural history of the orang utans

(Simia, Erxleben)." 2:165-172. 
Plate 34

subject: Simia morio

description and notes: lithograph; printed by $\mathrm{C}$. Hullmandel; plate signed G. Scharf del. et lithog.; gives view of base of skull

article: Owen, Kichard. "Osteological contributions to the natural history of the orang utans (Simia, Erxleben)." 2:165-172.

Plate 40

subject: Camelopardalis giraffa

description and notes: lithograph; printed by $\mathrm{C}$. Hullmandel; plate signed G. Scharf del. et lithog.; shows cross-section of skull

article: Owen, Richard. "Notes on the anatomy of the Nubian giraffe." 2:217-248.

Plate 41

subject: Camelopardalis giraffa

description and notes: lithograph; printed by $C$. Hullmandel; plate signed Lithog. from Nat. by G. Scharf; shows tongue

article: Owen, Richard. "Notes on the anatomy of the Nubian giraffe." 2:217-248.

Plate 42

subject: Camelopardalis giraffa

description and notes: lithograph; printed by $\mathrm{C}$. Hullmandel; plate signed Lithog. from Nat. by G. Scharf; shows internal organs

article: Owen, Richard. "Notes on the anatomy of the Nubian giraffe." 2:217-248.

Plate 44

subject: Camelopardalis giraffa

description and notes: lithograph; plate signed Lithog. from Nature by G. Scharf; shows brain article: Owen, Richard. "Notes on the anatomy of the Nubian giraffe." 2:217-248.

Plate 59

subject: Meles labradoria

description and notes: lithograph; plate signed Lithog. from Nat. by G. Scharf; gives views of skull

article: Waterhouse, George R. "On the skull of the North American badger, Meles labradoria of Authors." 2:343-348. 
Plate 70

subject: Thylacinus; Dasyurus

description and notes: lithograph; plate signed

Lithog. from Nature by G. Scharf; gives views of skulls

article: Owen, Richard. "On the osteology of the Marsupialia." 2:379-408.

Plate 71

subject: Perameles lagotis; Phalangista;

Petaurus; Hypsiprymnus; Macropus;

Phascolomys

description and notes: lithograph; plate signed

Lithog. from Nature by G. Scharf; gives views of skulls

article: Owen, Richard. "On the osteology of the Marsupialia." 2:379-408.

Volume 3 (1849)

Plate 2

subject: Camelopardalis giraffa

description and notes: lithograph; plate signed

Lithog. from Nat. by G. Scharf; shows anatomical details

article: Owen, Richard. "Notes on the birth of the giraffe at the Zoological Society's Gardens, and description of the foetal membranes and of some of the natural and morbid appearances observed

in the dissection of the young animal." $3: 21-28$.

Plate 3: "Femur of a Bird from New Zealand" subject: species unknown

description and notes: 1ithograph; plate signed Lithog. from Nature by G. Scharf

article: Owen, Richard. "Notice of a fragment of the femur of a gigantic bird of New Zealand." $3: 29-32$.

Plate 20a

subject: Dinornis didiformis

description and notes: lithograph; printed by $\mathrm{C}$. Hullmandel; plate signed lithog. from Nature by G. Scharf

article: Owen, [Professor]. "On Dinornis, an extinct genus of tridactyle struthious birds, with descriptions of portions of the skeleton of five species which formerly existed in New

Zealand." 3:235-275. 
Plate 21

subject: Dinornis ingens; Dinornis struthoides; Dinornis dromioides

description and notes: lithograph; printed by $C$. Hullmandel; plate signed lithog. from Nature by G. Scharf; figures shown natural size; double-page folded plate

article: Owen, [Professor]. "On Dinornis, an extinct genus of tridactyle struthious birds, with descriptions of portions of the skeleton of five species which formerly existed in New Zealand." $3: 235-275$.

Plate 22

subject: Dinornis dromioides

description and notes: lithograph; printed by $C$. Hullmandel; plate signed Lithog. from Nature by G. Scharf; figures shown natural size

article: Owen, [Professor]. "On Dinornis, an extinct genus of tridactyle struthious birds, with descriptions of portions of the skeleton of five species which formerly existed in New Zeal and." $3: 235-275$.

Plate 23

subject: Dinornis struthoides [juvenile]; Dinornis dromioides

description and notes: lithograph; printed by $\mathrm{C}$. Hullmandel; plate signed Lithog. from Nature by G. Scharf; figures shown natural size

article: Owen, [Professor]. "On Dinornis, an extinct genus of tridactyle struthious birds, with descriptions of portions of the skeleton of five species which formerly existed in New Zealand." $3: 235-275$.

Plate 24

subject: Dinornis didiformis

description and notes: lithograph; printed by $C$. Hullmandel; plate signed Lithog. from Nature by G. Scharf; figures shown natural size article: Owen, [Professor]. "On Dinornis, an extinct genus of tridactyle struthious birds, with descriptions of portions of the skeleton of five species which formerly existed in New Zealand." 3:235-275. 


\section{Plate 25}

subject: Dinornis

description and notes: lithograph; printed by $C$. Hullmandel; plate signed Lithog. from Nature by G. Scharf; figures shown natural size; triple-page folded plate

article: Owen, [Professor]. "On Dinornis, an extinct genus of tridactyle struthious birds, with descriptions of portions of the skeleton of five species which formerly existed in New Zealand." 3:235-275.

Plate 26

subject: Dinornis

description and notes: lithograph; printed by $C$. Hullmandel; plate signed Lithog. from Nature by G. Scharf; figures shown natural size; triple-page folded plate

article: Owen, [Professor]. "On Dinornis, an extinct genus of tridactyle struthious birds, with descriptions of portions of the skeleton of five species which formerly existed in New Zealand." 3:235-275.

Plate 41: "Inferior cervical vertebra" subject: Dinornis giganteus description and notes: lithograph; printed by Hullmandel \& Walton; plate signed Lithog. from Nature by G. Scharf; figures shown natural size article: Owen, [Professor]. "Observations on the dodo (Didus ineptus, Linn.); an appendix to the foregoing memoir on the Dinornis." $3: 331-338$. 
SCHAKF, Henry

Volume 2 (1841)

Plate 43

subject: Camelopardalis giraffa

description and notes: lithograph; printed by $\mathrm{C}$. Hullmandel; plate signed Henry Scharf del., G. Scharf lithog.; shows brain and spinal cord article: Owen, Richard. "Notes on the anatomy of the Nubian giraffe." 2:217-248.

Plate 45

subject: Camelopardalis giraffa

description and notes: lithograph; plate signed Henry Scharf del., G. Scharf lithog.; shows female reproductive organs

article: Owen, Richard. "Notes on the anatomy of the Nubian giraffe." 2:217-248.

Plate 47

subject: Apteryx australis; Rhea americana

description and notes: engraving; plate signed $\mathrm{H}$. Scharf Delin., J.C. Zeitter Sculp.

article: Owen, [Richard]. "On the anatomy of the southern Apteryx (Apteryx australis, Shaw)." $2: 257-301$.

Plate 48

subject: Apteryx australis

description and notes: engraving; plate signed $\mathrm{H}$. Scharf Delin., J.C. Zeitter Sculp.; shows details of anatomy

article: Owen, [Richard]. "On the anatomy of the southern Apteryx (Apteryx australis, Shaw)." $2: 257-301$.

Plate 50

subject: Apteryx australis

description and notes: engraving; plate signed $\mathrm{H}$. Scharf Delin., J.C. Zeitter Sculp.; shows details of anatomy

article: Owen, [Richard]. "On the anatomy of the southern Apteryx (Apteryx australis, Shaw)." $2: 257-301$. 
Plate 53

subject: Apteryx; Ibis

description and notes: engraving; plate signed $H$. Scharf Delin., W. Taylor Sculp.; shows skulls article: Owen, [Richard]. "On the anatomy of the southern Apteryx (Apteryx australis, Shaw)." $2: 257-301$.

\section{Plate 54}

subject: Apteryx australis

description and notes: engraving; plate signed $H$. Scharf Delin., J. Swaine sc.; shows articulated skeleton; figure shown $1 / 2$ natural size

article: Owen, [Richard]. "On the anatomy of the southern Apteryx (Apteryx australis, Shaw)." $2: 257-301$.

Plate 55

subject: Apteryx australis

description and notes: engraving; plate signed $\mathrm{H}$. Scharf del., Swaine Sc.; shows skeleton article: Owen, [Richard]. "On the anatomy of the southern Apteryx (Apteryx australis, Shaw)." $2: 257-301$.

Volume 11 (1885)

Plate 27

subject: Loligopsis ocellata

description and notes: hand-colored lithograph;

printed by Hanhart; plate signed H. Scharf del., on Stone by J. Erxleben; figure shown natural size

article: Owen, [Professor]. "Descriptions of some new and rare Cephalopoda. (Part II.)." $11: 131-170$. 
SCHARF, W. [fl. 1870s ]

Volume 3 (1849)

Plate 31 see Owen, 3: Plate 31

Plate 32 see Owen, 3: Plate 32

Plate 33 see Owen, 3: Plate 33

Plate 34 see Owen, 3: Plate 34

Plate 35 see Owen, 3: Plate 35 


\section{SCHWANWITSCH, B.N. (b. 1889)}

\section{Volume 21 (1916-1936)}

\section{Plate 8}

subject: Perisama goeringi Druce; Perisama emma emilina Obth.; Perisama comnena var.

intermedia Obth.; Perisama xanthica Hew.;

Perisama sp.; Perisama eminens Obth.;

Perisama euriclea D. \& H.; Perisama volara

Hew.; Perisama vaninka Hew.; Perisama patara

Hew.; Perisama saussurei Guér.; Perisama

hilara Salv.; Perisama lebasii Guér.;

Orophila diotima Hew.; Orophila sp.;

Orophila cardases Hew.; Perisama hilara

Salv.; Orophila calamis Hew.; Cyclogramma

bacchis Doubl.; Cyclogramma pandama D. \& $\mathrm{H}$.

description and notes: lithograph; printed by John Bale Sons \& Danielsson

article: Schwanwitsch, B.N. "Studies upon the wing-pattern of Catagramma and related genera of South American Nymphalid butterflies." $21: 105-294$.

Plate 9

subject: Cyclogramma bacchis Doubl.; Callicore ceryx Hew.; Callicore asteria G. \& S.;

Callicore gabaza Hew.; Callicore euclides

Latr.; Callicore eupepla G. \& S.; Callicore

anna Guér.; Callicore clymena Cram.;

Callicore marchalii Guér.; Callicore

neglecta Salv.; Callicore phogea S. \& G.;

Callicore candrena Godt.; Callicore clymena

Cram.; Callicore lidwina Feld.; Callicore

candrena Godt.; Catagramma pasithea Hew.;

Callicore kolyma Hew.

description and notes: lithograph; printed by John Bale Sons \& Danielsson

article: Schwanwitsch, B.N. "Studies upon the wing-pattern of Catagramma and related genera of South American Nymphalid butterflies." $21: 105-294$. 
Plate 10

subject: Lucinia sida Hübn.; Lucinia torrebia Mén.; Lucinia sida Hübn.; Catagramma pasithea Hew.; Lucinia cadma Dr.; Catagramma cyllene Doub1.; Catagramma pygas Godt.; Catagramma sorana Godt.; Catagramma latona But1.; Catagramma excelsior var. pastazza Stgr.; Catagramma astarte miles Bates; Catagramma astarte stratiotes Feld.; Catagramma astarte selima Guenée; Catagramma astarte Stgr.; Catagramma astarte rutila Guenée; Catagramma astarte Cram.

description and notes: lithograph; printed by John Bale Sons \& Danielsson

article: Schwanwitsch, B.N. "Studies upon the wing-pattern of Catagramma and related genera of South American Nymphalid butterflies." $21: 105-294$.

Plate 11

subject: Catagramma cynosura Doubl.; Catagramma costa Salv.; Catagramma pyracmon Godt.; Catagramma peristera Hew.; Catagramma hesperis Guér.; Catagramma felderi Hew.; Catagramma faustina Bates; Catagramma atacama Hew.; Catagramma apollinaris Obth.; Catagramma hydarnis Godt.; Catagramma eunomia carmen Obth.; Catagramma zelphanta Hew.; Catagramma eunomia Hew.; Catagramma pacifica Bates; Catagramma tolima Hew.; Catagramma denina Hew.

description and notes: lithograph; printed by John Bale Sons \& Danielsson

article: Schwanwitsch, B.N. "Studies upon the wing-pattern of Catagramma and related genera of South American Nymphalid butterflies." $21: 105-294$.

Plate 12

subject: Catagramma pitheas Latr.; Catagramma egina Feld.; Catagramma monina Hew.;

Catagramma odilia Ob.; Catagramma sp.;

Catagramma brome Boisd.; Catagramma

lyrophila Hübn.; Catagramma hydaspes (syn. lyrophila) Drury; Catagramma lyca D. \& H.; Catagramma maimuna Hew.; Catagramma titania Salv.; Catagramma texa Hew.

description and notes: lithograph; printed by John Bale Sons \& Danielsson

article: Schwanwitsch, B.N. "Studies upon the wing-pattern of Catagramma and related genera of South American Nymphalid butterflies." $21: 105-294$. 
SCOTT, John $\mathrm{H}$.

Volume $12(1890)$

Plate 48

subject: Ziphius

description and notes: lithograph; printed by west, Newman \& Co.; plate signed J.H.S. ad nat. del., Parker \& Coward lith.

article: Scott, John H. and T. Jeffery Parker. "On a species of Ziphius recently obtained near Dunedin." $12: 241-248$.

Plate 49

see Parker, 12: Plate 49

Plate 50

subject: Ziphius

description and notes: hand-colored lithograph; printed by West, Newman \& Co.; plate signed J.H.S. \& T.J.P. ad nat. delt., Parker \& Coward lith.

article: Scott, John H. and T. Jeffery Parker. "On a species of Ziphius recently obtained near Dunedin." 12:241-248. 
SEARLE, A.H.

Volume 18 (1907-1911)

Plate 10

subject: Palaeopropithecus maximus Standing

description and notes: lithograph; printed by West, Newman; plate signed A.H. Searle del. et lith.; figures shown natural size

article: Standing, Herbert F. and G. Elliot Smith. "On recently discovered subfossil primates from Madagascar. With an appendix: On the form of the brain in the extinct lemurs of Madagascar, with some remarks on the affinities of the Indrisinae." 18:59-216.

Plate 11

subject: Palaeopropithecus maximus Standing

description and notes: photolithograph?; printed by London Stereoscopic Co.; figures shown $6 / 7$ natural size

article: Standing, Herbert F. and G. Elliot Smith. "On recently discovered subfossil primates from Madagascar. With an appendix: On the form of the brain in the extinct lemurs of Madagascar, with some remarks on the affinities of the Indrisinae." 18:59-216.

Plate 12

subject: Palaeopropithecus maximus Standing

description and notes: photolithograph?; printed by London Stereoscopic Co.; figures shown $4 / 5$

natural size; double-page plate

article: Standing, Herbert F. and G. Elliot Smith.

"On recently discovered subfossil primates from Madagascar. With an appendix: On the form of the brain in the extinct lemurs of Madagascar, with some remarks on the affinities of the Indrisinae." 18:59-216. 
Plate 13

subject: Palaeopropithecus maximus Standing

description and notes: photolithograph?; printed by London Stereoscopic Co.; figures shown $1 / 2$ natural size

article: Standing, Herbert F. and G. Elliot Smith. "On recently discovered subfossil primates from Madagascar. With an appendix: Cn the form of the brain in the extinct lemurs of Madagascar, with some remarks on the affinities of the Indrisinae." 18:59-216.

Plate 14

subject: Palaeopropithecus maximus Standing

description and notes: photolithograph?; printed by London Stereoscopic Co.; figures shown $1 / 2$ natural size

article: Standing, Herbert F. and G. Elliot Smith. "On recently discovered subfossil primates from Madagascar. With an appendix: On the form of the brain in the extinct lemurs of Madagascar, with some remarks on the affinities of the Indrisinae." 18:59-216.

Plate 15

subject: Palaeopropithecus maximus Standing

description and notes: photolithograph?; printed by London Stereoscopic Co.

article: Standing, Herbert F. and G. Elliot Smith. "On recently discovered subfossil primates from Madagascar. With an appendix: On the form of the brain in the extinct lemurs of Madagascar, with some remarks on the affinities of the Indrisinae." 18:59-216.

Plate 16

subject: Archaeolemur edwardsi Filhol

description and notes: lithograph; printed by west, Newman; plate signed A.H. Searle del. et lith.; figures shown natural size

article: Standing, Herbert F. and G. Elliot Smith. "On recently discovered subfossil primates from Madagascar. With an appendix: On the form of the brain in the extinct lemurs of Madagascar, with some remarks on the affinities of the Indrisinae." 18:59-216. 
Plate 17

subject: Archaeolemur edwardsi Filhol

description and notes: photolithograph?; printed by London Sterecscopic Co.; figures shown $4 / 7$ natural size

article: Standing, Herbert F. and G. Elliot Smith. "On recently discovered subfossil primates from Madagascar. With an appendix: on the form of the brain in the extinct lemurs of Madagascar, with some remarks on the affinities of the Indrisinae." 18:59-216.

Plate 18

subject: Archaeolemur edwardsi Filhol

description and notes: photolithograph?; printed by London Stereoscopic Co.; figures shown $3 / 4$ natural size

article: Standing, Herbert F. and G. Elliot Smith. "On recently discovered subfosil primates from Madagascar. With an appendix: On the form of the brain in the extinct lemurs of Madagascar, with some remarks on the affinities of the Indrisinae." 18:59-216.

Plate 19

subject: Archaeolemur platyrrhinus Standing

description and notes: lithograph; printed by West, Newman; plate signed A.H. Searle del. et lith. article: Standing, Herbert F. and G. Eliiot Smith. "On recently discovered subfossil primates from Madagascar. With an appendix: On the form of the brain in the extinct lemurs of Madagascar, with some remarks on the affinities of the Indrisinae." 18:59-216.

Plate 20

subject: Archaeolemur edwardsi; Archaeolemur platyrrhinus

description and notes: photolithograph?; printed by London Stereoscopic Co.; figures shown $1 / 2$ natural size

article: Standing, Herbert F, and G. Elliot Smith. "On recently discovered subfossil primates from Madagascar. With an appendix: On the form of the brain in the extinct lemurs of Madagascar, with some remarks on the affinities of the Indrisinae." 18:59-216. 
Plate 21

subject: Mesopropithecus pithecoides Standing

description and notes: lithograph; printed by West, Newman; plate signed A.H. Searle del. et lith.; figures shown natural size

article: Standing, Herbert F. and G. Elliot Smith. "On recently discovered subfossil primates from Madagascar. With an appendix: On the form of the brain in the extinct lemurs of Madagascar, with some remarks on the affinities of the Indrisinae." 18:59-216.

\section{Plate 22}

subject: Mesopropithecus pithecoides Standing description and notes: lithograph; printed by West, Newman; plate signed A.H. Searle del. et lith.; figures shown natural size

article: Standing, Herbert F. and G. Elliot Smith. "On recently discovered subfossil primates from Madagascar. With an appendix: On the form of the brain in the extinct lemurs of Madagascar, with some remarks on the affinities of the Indrisinae." 18:59-216.

Plate 23

subject: Archaeolemur edwardsi Filhol; Mesopropithecus pithecoides Standing

description and notes: lithograph; printed by West, Newman; plate signed A.H. Searle del. et lith. article: Standing, Herbert F. and G. Elliot Smith. "On recently discovered subfossil primates from Madagascar. With an appendix: On the form of the brain in the extinct lemurs of Madagascar, with some remarks on the affinities of the Indrisinae." 18:59-216.

Plate 24

subject: Megaladapis grandidieri

description and notes: photolithograph?; printed by London Stereoscopic Co.; figure shown $4 / 5$ natural size

article: Standing, Herbert F, and G. Elliot Smith. "On recently discovered subfossil primates from Madagascar. With an appendix: On the form of the brain in the extinct lemurs of Madagascar, with some remarks on the affinities of the Indrisinae." 18:59-216. 
Plate 25

subject: Megaladapis grandidieri

description and notes: photolithograph?; printed by London Stereoscopic Co.; figure shown $3 / 4$ natural size

article: Standing, Herbert F. and G. Elliot Smith. "On recently discovered subfossil primates from Madagascar. With an appendix: On the form of the brain in the extinct lemurs of Madagascar, with some remarks on the affinities of the Indrisinae." 18:59-216.

Plate 26

subject: Megaladapis grandidieri

description and notes: photolithograph?; printed by London Stereoscopic Co.; figure shown 4/5 natural size

article: Standing, Herbert F. and G. Elliot Smith. "On recently discovered subfossil primates from Madagascar. With an appendix: On the form of the brain in the extinct lemurs of Madagascar, with some remarks on the affinities of the Indrisinae." 18:59-216.

Plate 27

subject: Lemur jullyi

description and notes: photolithograph?; printed by London Stereoscopic Co.

article: Standing, Herbert F. and G. Elliot Smith. "On recently discovered subfossil primates from Madagascar. With an appendix: On the form of the brain in the extinct lemurs of Madagascar, with some remarks on the affinities of the Indrisinae." 18:59-216.

Plate 28

subject: Lemur majori

description and notes: photolithograph?; printed by London Stereoscopic Co.

article: Standing, Herbert F. and G. Elliot Smith. "On recently discovered subfossil primates from Madagascar. With an appendix: On the form of the brain in the extinct lemurs of Madagascar, with some remarks on the affinities of the Indrisinae." 18:59-216. 


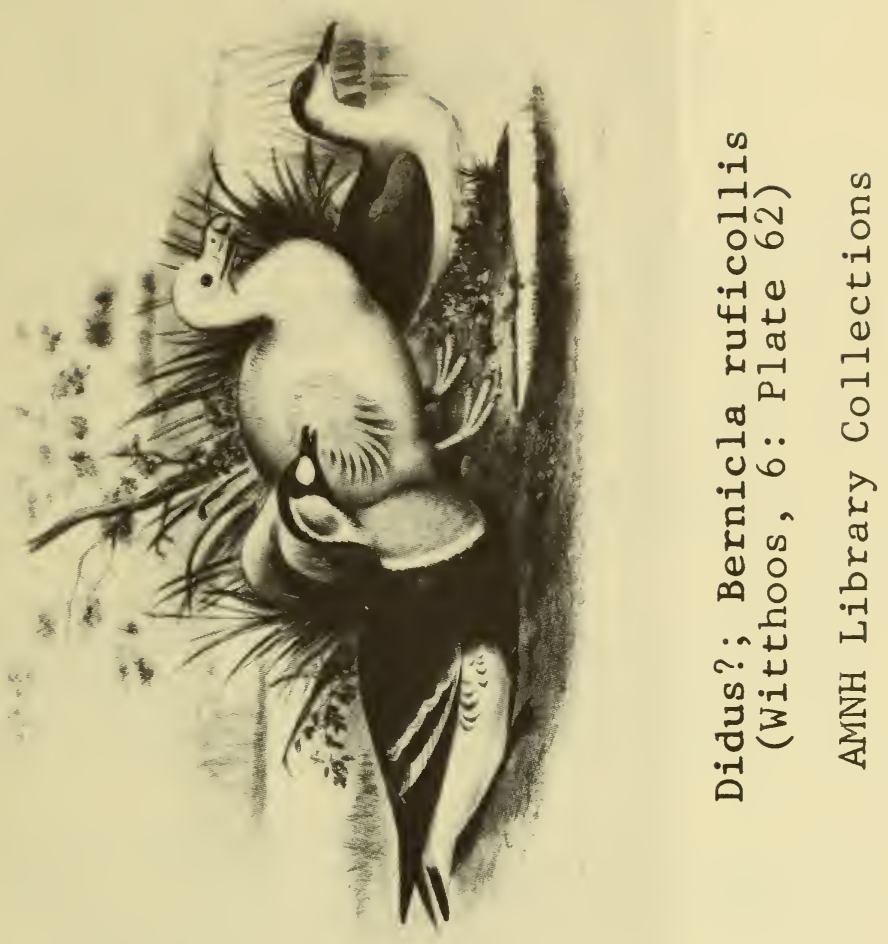





\section{SMIT, Joseph (1836-1929)}

Volume $6(1869)$

Plate 19

subject: Didus ineptus

description and notes: lithograph; printed by M. \& N. Hanhart

article: Owen, [Professor]. "On the osteology of the dodo (Didus ineptus, Linn.)." 6:49-85.

Plate 21

subject: Didus ineptus

description and notes: lithograph; printed by M. \& N. Hanhart

article: Owen, [Professor]. "On the osteology of the dodo (Didus ineptus, Linn.)." 6:49-85.

Plate 22

subject: Didus ineptus

description and notes: lithograph; printed by M. \& $\mathrm{N}$. Hanhart

article: Owen, [Professor]. "On the osteology of the dodo (Didus ineptus, Linn.)." 6:49-85.

Plate 23

subject: Didus ineptus

description and notes: 1ithograph; printed by M. \& N. Hanhart

article: Owen, [Professor]. "On the osteology of the dodo (Didus ineptus, Linn.)." 6:49-85.

Plate 25

subject: Inia geoffrensis

description and notes: lithograph; printed by $M$. \& $N$. Hanhart; figures shown $1 / 2$ and $1 / 4$ natural size; double-page folded plate

article: Flower, William Henry. "Description of the skeleton of Inia geoffrensis and of the skull of Pontoporia blainvillii, with remarks on the systematic position of these animals in the order Cetacea." 6:87-116. 
Plate 26

subject: Inia geoffrensis

description and notes: lithograph; printed by M. \& $\mathrm{N}$. Hanhart; figures shown $1 / 2$ natural size

article: Flower, William Henry. "Description of the skeleton of Inia geoffrensis and of the skull of Pontoporia blainvillii, with remarks on the systematic position of these animals in the order Cetacea." 6:87-116.

\section{Plate 27}

subject: Inia geoffrensis

description and notes: 1ithograph; printed by M. \& $N$. Hanhart; figures shown $1 / 2$ natural size

article: Flower, William Henry. "Description of the skeleton of Inia geoffrensis and of the skull of Pontoporia blainvillii, with remarks on the systematic position of these animals in the order Cetacea." 6:87-116.

Plate 28

subject: Pontoporia blainvillii

description and notes: lithograph; printed by M. \& $N$. Hanhart; figures shown $1 / 2$ natural size

article: Flower, William Henry. "Description of the skeleton of Inia geoffrensis and of the skull of Pontoporia blainvilii, with remarks on the systematic position of these animals in the order Cetacea." 6:87-116.

Plate 55

subject: Physeter macrocephalus

description and notes: lithograph; printed by M.\& N. Hanhart; four-page folded plate; shows full skeleton; figure shown $1 / 24$ natural size

article: Flower, William Henry. "On the osteology of the cachalot or sperm-whale (Physeter macrocephalus)." $6: 309-372$.

Plate 56

subject: Physeter macrocephalus; Hyperoodon

description and notes: lithograph; printed by $M$. \& N. Hanhart; three-page folded plate; shows skul1s; figure shown $1 / 12$ natural size

article: Flower, William Henry. "On the osteology of the cachalot or sperm-whale (Physeter macrocephalus)." $6: 309-372$. 
Plate 57

subject: Physeter macrocephalus

description and notes: lithograph; printed by $M$. \& $\mathrm{N}$. Hanhart; shows skul1; figure shown $1 / 9$ natural size

article: Flower, William Henry. "On the osteology of the cachalot or sperm-whale (Physeter macrocephalus)." $6: 309-372$.

Plate 58

subject: Physeter macrocephalus

description and notes: lithograph; printed by $M$. \& $\mathrm{N}$. Hanhart; shows vertebral column; figure shown $1 / 12$ natural size

article: Flower, William Henry. "On the osteology of the cachalot or sperm-whale (Physeter macrocephalus). "6:309-372.

Plate 59

subject: Physeter macrocephalus

description and notes: lithograph; printed by $M$. \& N. Hanhart; three-page folded plate; shows vertebral column; figure shown $1 / 12$ natural size article: Flower, William Henry. "On the osteology of the cachalot or sperm-whale (Physeter macrocephalus)." $6: 309-372$.

Plate 60

subject: Physeter macrocephalus

description and notes: lithograph; printed by $M$. \& N. Hanhart; figures shown $1 / 6$ or $1 / 12$ natural size

article: Flower, William Henry. "On the osteology of the cachalot or sperm-whale (Physeter macrocephalus)." $6: 309-372$.

Plate 61

subject: Physeter macrocephalus

description and notes: lithograph; printed by M. \& $N$. Hanhart; figures shown $1 / 6$ natural size article: Flower, William Henry. "On the osteology of the cachalot or sperm-whale (Physeter macrocephalus)." $6: 309-372$. 
Volume 7 (1872)

Plate 10

subject: Dinornis elephantopus

description and notes: lithograph; printed by $M$. \& $\mathrm{N}$. Hanhart

article: Owen, [Professor]. "On Dinornis (Part XIV.): containing contributions to the craniology of the genus, with a description of the fossil cranium of Dasornis londinensis, Ow., from the London Clay of Sheppey." 7:123-150.

Plate 12

subject: Dinornis rheides

description and notes: lithograph; printed by M. \& $\mathrm{N}$. Hanhart; plate signed J. Smit del. et lith. article: Owen, [Professor]. "On Dinornis (Part XIV.): containing contributions to the craniology of the genus, with a description of the fossil cranium of Dasornis londinensis, Ow., from the London Clay of Sheppey." 7:123-150.

Plate 13

subject: Dinornis casuarinus; Dinornis casuarinus

description and notes: lithograph; printed by M. \& N. Hanhart

article: Owen, [Professor]. "On Dinornis (Part XIV.): containing contributions to the craniology of the genus, with a description of the fossil cranium of Dasornis londinensis, Ow., from the London Clay of Sheppey." 7:123-150.

Plate 14

subject: Dinornis gravis

description and notes: lithograph; printed by M. \& $N$. Hanhart; plate signed J. Smit del. et lith. article: Owen, [Professor]. "On Dinornis (Part XIV.): containing contributions to the craniology of the genus, with a description of the fossil cranium of Dasornis londinensis, Ow., from the London Clay of Sheppey." 7:123-150.

Plate 17

subject: Delphinus sinensis

description and notes: lithograph; printed by M. \& $\mathrm{N}$. Hanhart; three-page folded plate; shows articulated skeleton; figure shown $1 / 4$ natural size

article: Flower, William Henry. "Description of the skeleton of the Chinese white dolphin (Delphinus sinensis, Osbeck)." 7:151-160. 
Plate 18

subject: Delphinus sinensis

description and notes: 1ithograph; printed by $M$. \& $\mathrm{N}$. Hanhart; shows skull and vertebrae

article: Flower, William Henry. "Description of the skeleton of the Chinese white dolphin

(Delphinus sinensis, Osbeck)." 7:151-160.

Plate 24

subject: Caprimulgus inornatus

description and notes: hand-colored lithograph; printed by M. \& N. Hanhart; signed "J. Smit"

article: Finsch, Otto and William Jesse. "On a

collection of birds from north-eastern Abysinia and the Bogos country. With notes by the collector. $7: 197-331$.

Plate 25

subject: Lanius fallax

description and notes: hand-colored lithograph; printed by M. \& N. Hanhart; signed "J.S."

article: Finsch, Otto and William Jesse. "On a

collection of birds from north-eastern Abyssinia and the Bogos country. With notes by the collector." 7:197-331.

Plate 26

subject: Coraphites melanauchen

description and notes: hand-colored lithograph; printed by $M$. \& N. Hanhart

article: Finsch, Otto and William Jesse. "On a collection of birds from north-eastern Abysinia and the Bogos country. With notes by the collector. $7: 197-331$.

Plate 27

subject: Larus hemprichii

description and notes: hand-colored lithograph; printed by M. \& N. Hanhart; signed "J. Smit"; figures shown $1 / 2$ natural size

article: Finsch, Otto and William Jesse. "On a collection of birds from north-eastern Abysinia and the Bogos country. With notes by the collector. $7: 197-331$.

Plate 28

subject: Cervus davidianus

description and notes: hand-colored lithograph; printed by M. \& N. Hanhart; signed "J. Smit" article: Sclater, F.L. "On certain species of deer now or lately living in the Society's

Menagerie." $7: 333-352$. 
Plate 30

subject: Cervus cashmeerianus

description and notes: hand-colored lithograph; printed by M. \& N. Hanhart; signed "J.S."

article: Sclater, P.L. "On certain species of deer now or lately living in the Society's Menagerie." 7:333-352.

Plate 32

subject: Cervus mantchuricus

description and notes: hand-colored lithograph; printed by M. \& N. Hanhart; plate signed J. Smit, lith.

article: Sclater, P.L. "On certain species of deer now or lately living in the Society's Menagerie." 7:333-352.

Plate 34

subject: Cervus taivanus [female]

description and notes: hand-colored lithograph; printed by M. \& N. Hanhart; plate signed J. Smit, lith.

article: Sclater, P.L. "On certain species of deer now or lately living in the Society's Menagerie." 7:333-352.

Plate 38

subject: Cervus eldi [male]

description and notes: hand-colored lithograph; printed by M. \& N. Hanhart; plate signed J. Smit, lith.

article: Sclater, F.L. "On certain species of deer now or lately living in the Society's Menagerie." 7:333-352.

Plate 58

subject: Micropterus cinereus

description and notes: lithograph; printed by M. \& $\mathrm{N}$. Hanhart

article: Cunningham, Robert 0 . "On some points in the anatomy of the steamer duck (Micropterus cinereus)." 7:493-501.

Plate 59

subject: Micropterus cinereus

description and notes: lithograph; printed by M. \& $\mathrm{N}$. Hanhart

article: Cunningham, Robert 0 . "On some points in the anatomy of the steamer duck (Micropterus cinereus)." 7:493-501. 
Plate 60

subject: Micropterus cinereus

description and notes: lithograph; printed by M. \& $N$. Hanhart

article: Cunningham, Robert 0 . "On some points in the anatomy of the steamer duck (Micropterus cinereus)." 7:493-501.

Plate 61

subject: Micropterus cinereus

description and notes: lithograph; printed by M. \& N. Hanhart

article: Cunningham, Robert 0 . "On some points in the anatomy of the steamer duck (Micropterus cinereus)." 7:493-501.

Plate 62

subject: Micropterus cinereus

description and notes: lithograph; printed by M. \& $\mathrm{N}$. Hanhart

article: Cunningham, Robert 0 . "On some points in the anatomy of the steamer duck (Micropterus cinereus)." 7:493-501.

Volume 8 (1874)

Plate 1

subject: Grampus griseus

description and notes: hand-colored lithograph;

printed by $M$. \& $N$. Hanhart; figures shown $1 / 15$

natural size; from drawings by R.W. Sherwin and E. Gerrard, Jr.

article: Flower, William Henry. "On Risso's dolphin, Grampus griseus (Cuv.)." $8: 1-21$.

Plate 4

subject: Trichoglossus meyeri

description and notes: hand-colored lithograph; printed by $M$. \& N. Hanhart

article: Walden, Arthur Viscount. "A list of the birds known to inhabit the island of Celebes." $8: 23-108$.

Plate 5

subject: Buceros exaratus [male and female] description and notes: hand-colored lithograph; printed by $M . \& N$. Hanhart; figures shown $1 / 2$ natural size

article: Walden, Arthur Viscount. "A list of the birds known to inhabit the island of Celebes." 8:23-108. 
Plate 6

subject: Artamus monachus; Geocichla erythronota description and notes: hand-colored lithograph; printed by $M$. \& $N$. Hanhart

article: Walden, Arthur Viscount. "A list of the birds known to inhabit the island of Celebes." $8: 23-108$.

Plate 7

subject: Myialestes helianthea; Hypothymis puella; Cyornis rufigula

description and notes: hand-colored lithograph; printed by $M$. \& $N$. Hanhart

article: Walden, Arthur Viscount. "A list of the birds known to inhabit the island of Celebes." $8: 23-108$.

Plate 8

subject: Volvocivora morio; Lalage leucopygialis description and notes: hand-colored lithograph; printed by $M$. \& N. Hanhart

article: Walden, Arthur Viscount. "A list of the birds known to inhabit the island of Celebes." $8: 23-108$.

Plate 9

subject: Munia brunneiceps; Zosterops

intermedia; Zosterops atrifrons

description and notes: hand-colored lithograph; printed by $M$. \& $N$. Hanhart

article: Walden, Arthur Viscount. "A list of the birds known to inhabit the island of Celebes." $8: 23-108$.

Plate 10

subject: Acridotheres cinereus; Aegialites peronii

description and notes: hand-colored lithograph; printed by $M$. \& $N$. Hanhart

article: Walden, Arthur Viscount. "A list of the birds known to inhabit the island of Celebes." $8: 23-108$.

Plate 11

subject: Teraspiza rhodogaster [female, juvenile] description and notes: hand-colored lithograph; printed by M. \& N. Hanhart; figure shown $3 / 4$ natural size

article: Walden, Arthur Viscount. "Appendix to a list of birds known to inhabit the island of Celebes." 8:109-118. 
Plate 12

subject: Graucalus temmincki

description and notes: hand-colored lithograph; printed by M. \&N. Hanhart; signed "J. Smit"; figure shown $3 / 4$ natural size

article: Walden, Arthur Viscount. "Appendix to a list of birds known to inhabit the island of Celebes." 8:109-118.

Plate 13

subject: Hieroccoccyx crassirostris [adult and hepatic phase]

description and notes: hand-colored lithograph; printed by M. \& N. Hanhart; signed "J. Smit"; figures shown $1 / 2$ natural size

article: Walden, Arthur Viscount. "Appendix to a list of birds known to inhabit the island of Celebes." 8:109-118.

Plate 50

subject: Phascolomys platyrhinus; Phascolomys vombatus; Phascolomys latifrons

description and notes: lithograph; printed by $M$. \& $N$. Hanhart

article: Owen, [Professor]. "On the osteology of the Marsupialia. (Part III.) Modifications of the skeleton in the species of Phascolomys." $8: 345-360$.

Plate 51

subject: Phascolomys platyrhinus; Phascolomys vombatus; Phascolomys latifrons

description and notes: lithograph; printed by M. \& N. Hanhart

article: Owen, [Professor]. "On the osteology of the Marsupialia. (Part III.) Modifications of the skeleton in the species of Phascolomys." $8: 345-360$.

Plate 52

subject: Phascolomys platyrhinus; Phascolomys vombatus; Phascolomys latifrons

description and notes: 1ithograph; printed by M. \& $N$. Hanhart

article: Owen, [Professor]. "On the osteology of the Marsupialia. (Part III.) Modifications of the skeleton in the species of Phascolomys." $8: 345-360$. 


\section{Plate 53}

subject: Phascolomys latifrons; Phascolomys platyrhinus

description and notes: lithograph; printed by $M$. \& N. Hanhart

article: Owen, [Professor]. "On the osteology of the Marsupialia. (Part III.) Modifications of the skeleton in the species of Phascolomys." $8: 345-360$.

\section{Plate 54}

subject: Phascolomys vombatus; Phascolomys platyrhinus; Phascolomys latifrons

description and notes: lithograph; printed by $M$. \& N. Hanhart

article: Owen, [Professor]. "On the osteology of the Marsupialia. (Part III.) Modifications of the skeleton in the species of Phascolomys." $8: 345-360$.

\section{Plate 55}

subject: Phascolomys vombatus; Phascolomys platyrhinus; Phascolomys latifrons

description and notes: lithograph; printed by $M$. \& N. Hanhart

article: Owen, [Professor]. "On the osteology of the Marsupialia. (Part III.) Modifications of the skeleton in the species of Phascolomys." $8: 345-360$.

\section{Plate 56}

subject: Phascolomys platyrhinus; Phascolomys vombatus; Phascolomys latifrons

description and notes: lithograph; printed by M. \& N. Hanhart

article: Owen, [Professor]. "On the osteology of the Marsupialia. (Part III.) Modifications of the skeleton in the species of Phascolomys." $8: 345-360$.

\section{Plate 57}

subject: Phascolomys platyrhinus; Phascolomys vombatus; Phascolomys latifrons

description and notes: lithograph; printed by M. \& N. Hanhart

article: Owen, [Professor]. "On the osteology of the Marsupialia. (Part III.) Modifications of the skeleton in the species of Phascolomys." $8: 345-360$. 
Plate 65: "New Hydroids of the Porcupine Expeditions" subject: Thuiaria laxa; Thuiaria hippuris;

Thuiaria salicornia

description and notes: lithograph; printed by M. \& N. Hanhart

article: Allman, G.J. "Report on the Hydroida collected during the expeditions of H.M.S. 'Porcupine. "' $8: 469-481$.

Plate 66: "New Hydroids of the Porcupine Expeditions" subject: Lafoëa halecioides; Diphasia coronifera; Sertularella gayi var. robusta description and notes: lithograph; printed by M. \& N. Hanhart

article: Allman, G.J. "Report on the Hydroida collected during the expeditions of H.M.S. 'Porcupine.'" 8:469-481.

Plate 67: "New Hydroids of the Porcupine Expeditions" subject: Aglaophenia dromaius; Aglaophenia elongata; Halicornaria ramulifera

description and notes: lithograph; printed by M. \& N. Hanhart

article: Allman, G.J. "Report on the Hydroida collected during the expeditions of H.M.S. 'Porcupine. " 8:469-481.

Plate 68: "New Hydroids of the Porcupine Expeditions" subject: Cladocarpus formosus; Diplopteron insigne

description and notes: lithograph; printed by M. \& N. Hanhart

article: Allman, G.J. "Report on the Hydroida collected during the expeditions of H.M.S. 'Porcupine. " $8: 469-481$.

Plate 69

subject: Phascolomys latifrons; Phascolomys platyrhinus

description and notes: 1ithograph; printed by M. \& N. Hanhart

article: Owen, [Professor]. "On the osteology of the Marsupialia. (Part IV.) Bones of the trunk and limbs, Phascolomys." 8:483-500.

Plate 70

subject: Phascolomys latifrons; Phascolomys platyrhinus

description and notes: lithograph; printed by M. \& $\mathrm{N}$. Hanhart

article: Owen, [Professor]. "On the osteology of the Marsupialia. (Part IV.) Bones of the trunk and limbs, Phascolomys." 8:483-500. 
Plate 71

subject: Phascolomys latifrons; Phascolomys platyrhinus

description and notes: 1ithograph; printed by M. \& N. Hanhart

article: Owen, [Professor]. "On the osteology of the Marsupialia. (Part IV.) Bones of the trunk and limbs, Phascolomys." 8:483-500.

Plate 72

subject: Phascolomys latifrons; Phascolomys platyrhinus

description and notes: lithograph; printed by M. \& N. Hanhart

article: Owen, [Professor]. "On the osteology of the Marsupialia. (Part IV.) Bones of the trunk and limbs, Phascolomys." $8: 483-500$.

Plate 73

subject: Phascolomys latifrons; Phascolomys platyrhinus

description and notes: 1ithograph; printed by M. \& N. Hanhart

article: Owen, [Professor]. "On the osteology of the Marsupialia. (Part IV.) Bones of the trunk and limbs, Phascolomys." 8:483-500.

Plate 74

subject: Phascolomys latifrons

description and notes: lithograph; printed by $M$. \& $\mathrm{N}$. Hanhart

article: Owen, [Professor]. "On the osteology of the Marsupialia. (Part IV.) Bones of the trunk and limbs, Phascolomys." 8:483-500.

Volume 9 (1877)

Plate 24

subject: Limnaëtus philippensis

description and notes: hand-colored lithograph;

printed by $M . \& N$. Hanhart; signed "J. Smit";

figure shown $1 / 2$ natural size

article: Walden, Arthur. "A list of the birds known

to inhabit the Philippine Archipelago."

$9: 125-252$. 
Plate 25

subject: Ninox philippensis; Pseudoptynx

philippensis; Lempijius megalotis

description and notes: hand-colored lithograph;

printed by M. \& N. Hanhart; signed "J. Smit";

figures shown $1 / 2$ natural size

article: Walden, Arthur. "A list of the birds known to inhabit the Philippine Archipelago."

$9: 125-252$.

Plate 26

subject: Merops bicolor; Merops sumatranus

description and notes: hand-colored lithograph;

printed by M. \& N. Hanhart; signed "J. Smit";

figures shown $3 / 4$ natural size

article: Walden, Arthur. "A 1 ist of the birds known to inhabit the Philippine Archipelago."

9:125-252.

Plate 27

subject: Cranorrhinus leucocephalus [male and female] description and notes: hand-colored lithograph;
printed by M. \& N. Hanhart; signed "J. Smit"; figures shown $1 / 2$ natural size

article: Walden, Arthur. "A list of the birds known to inhabit the Philippine Archipelago." $9: 125-252$.

Plate 28

subject: Penelopides panini [male and female]

description and notes: hand-colored lithograph; printed by M. \& N. Hanhart; signed "J. Smit"; figures shown $1 / 2$ natural size

article: Walden, Arthur. "A list of the birds known to inhabit the Philippine Archipelago."

9:125-252.

Plate 29

subject: Lanius lucionensis; Pseudolalage melanoleuca

description and notes: hand-colored lithograph; printed by $M$. \& N. Hanhart; signed "J. Smit" article: Walden, Arthur. "A list of the birds known to inhabit the Philippine Archipelago." $9: 125-252$. 
Plate 30

subject: Graucalus striatus; Volvocivora caerulescens

description and notes: hand-colored lithograph; printed by M. \& N. Hanhart; signed "J. Smit"; figures shown $2 / 3$ natural size

article: Walden, Arthur. "A list of the birds known to inhabit the Philippine Archipelago." $9: 125-252$.

Plate 31

subject: Dicrurus balicassius; Hyloterpe philippensis

description and notes: hand-colored lithograph; printed by $M$. \& N. Hanhart; signed "J.S.";

figures shown $3 / 4$ natural size

article: Walden, Arthur. "A list of the birds known to inhabit the Philippine Archipelago." $9: 125-252$.

Plate 32

subject: Philentoma cyaniceps; Pycnonotus urostictus

description and notes: hand-colored lithograph; printed by M. \& N. Hanhart; signed "J. Smit" article: Walden, Arthur. "A list of the birds known to inhabit the Philippine Archipelago." $9: 125-252$.

Plate 33

subject: Copsychus mindanensis; Amaurornis olivacea

description and notes: hand-colored lithograph; printed by M. \& N. Hanhart; signed "J. Smit"; figures shown $2 / 3$ natural size article: Walden, Arthur. "A list of the birds known to inhabit the Philippine Archipelago." $9: 125-252$.

Plate 34

subject: Leucotreron gironieri; Phapitreron amethystina description and notes: hand-colored lithograph;
printed by M. \& N. Hanhart; signed "J. Smit";

figures shown $2 / 3$ natural size

article: Walden, Arthur. "A list of the birds known to inhabit the Philippine Archipelago." $9: 125-252$. 
Plate 40

subject: Crax globicera [male and female]

description and notes: hand-colored lithograph; printed by $M$. \& N. Hanhart; signed "J. Smit"

article: Sclater, P.L. "On the curassows now or

lately living in the Society's Gardens."

$9: 273-288$.

Plate 41

subject: Crax daubentoni [male]

description and notes: hand-colored lithograph;

printed by $M$. \& N. Hanhart; signed "J. Smit";

figure shown $1 / 3$ natural size

article: Sclater, P.L. "On the curassows now or lately living in the Society's Gardens."

9:273-288.

Plate 42

subject: Crax daubentoni [female]

description and notes: hand-colored lithograph; printed by $M . \& N$. Hanhart; signed "J. Smit";

figure shown $1 / 3$ natural size

article: Sclater, P.L. "On the curassows now or lately living in the Society's Gardens."

9:273-288.

Plate 43

subject: Crax alector [male and female]

description and notes: hand-colored lithograph; printed by M. \& N. Hanhart; signed "J. Smit" article: Sclater, P.L. "On the curassows now or lately living in the Society's Gardens." 9:273-288.

Plate 44

subject: Crax sclateri [male and female]

description and notes: hand-colored lithograph; printed by $M . \& N$. Hanhart; signed "J. Smit"; figures shown $1 / 3$ natural size

article: Sclater, P.L. "On the curassows now or lately living in the Society's Gardens." $9: 273-288$.

Plate 45

subject: Crax sclateri [female]

description and notes: hand-colored lithograph; printed by $M$. \& N. Hanhart; signed "J. Smit"

article: Sclater, P.L. "On the curassows now or lately living in the Society's Gardens." 9:273-288. 
Plate 46

subject: Crax globulosa [male and female]

description and notes: hand-colored lithograph; printed by M. \& N. Hanhart; signed "J. Smit"

article: Sclater, P.L. "On the curassows now or lately living in the Society's Gardens." $9: 273-288$.

Plate 47

subject: Crax carunculata [male and female]

description and notes: hand-colored lithograph; printed by $11 . \& N$. Hanhart; signed "J. Smit"; figures shown $1 / 3$ natural size

article: Sclater, P.L. "On the curassows now or lately living in the Society's Gardens." $9: 273-288$.

Plate 48

subject: Crax alberti [male and female]

description and notes: hand-colored lithograph; printed by M. \&N. Hanhart; signed "J. Smit"; figures shown $1 / 3$ natural size

article: Sclater, P.L. "On the curassows now or lately living in the Society's Gardens." 9:273-288.

Plate 49

subject: Crax incommoda

description and notes: hand-colored lithograph; printed by M. \& N. Hanhart; signed "J. Smit"; figure shown $1 / 3$ natural size

article: Sclater, P.L. "On the curassows now or lately living in the Society's Gardens." 9:273-288.

Plate 50

subject: Nothocrax urumutum

description and notes: hand-colored lithograph; printed by Hanhart; signed "J.S."; figure shown $1 / 3$ natural size

article: Sclater, P.L. "On the curassows now or lately living in the Society's Gardens." $9: 273-288$.

Plate 51

subject: Mitua tuberosa

description and notes: hand-colored lithograph; printed by Hanhart; signed "J. Smit"

article: Sclater, P.L. "On the curassows now or lately living in the Society's Gardens." $9: 273-288$. 
Plate 52

subject: Mitua tomentosa

description and notes: hand-colored lithograph;

printed by Hanhart; signed "J. Smit"

article: Sclater, P.L. "On the curassows now or

lately living in the Society's Gardens."

$9: 273-288$.

Plate 53

subject: Pauxi galeata; Pauxis galeata var. rubra

description and notes: hand-colored lithograph; printed by Hanhart; signed "J. Smit"

article: Sclater, P.L. "On the curassows now or lately living in the Society's Gardens." 9:273-288.

Plate 63

subject: Opisthocomus cristatus

description and notes: 1ithograph; printed by M. \& N. Hanhart

article: Perrin, J. Beswick. "On the myology of

Opisthocomus cristatus." 9:353-370.

Plate 64

subject: Opisthocomus cristatus

description and notes: lithograph; printed by $M$. \& N. Hanhart

article: Perrin, J. Beswick. "On the myology of

Opisthocomus cristatus." 9:353-370.

Plate 65

subject: Opisthocomus cristatus

description and notes: 1ithograph; printed by $M$. \& N. Hanhart

article: Perrin, J. Beswick. "On the myology of

Opisthocomus cristatus." 9:353-370.

Plate 66

subject: Opisthocomus cristatus

description and notes: lithograph; printed by $M$. \& N. Hanhart

article: Perrin, J. Beswick. "On the myology of

Opisthocomus cristatus." 9:353-370.

Plate 97

see Wolf, 9: Plate 97 
Volume 10 (1879)

Plate 28

subject: Manatus americanus

description and notes: lithograph; printed by

Hanhart; plate shows manatee's lips contracted and expanded

article: Garrod, A.H. "Notes on the manatee

(Manatus americanus) recently living in the Society's Gardens." 10:137-145.

Plate 29: "Liver of Manatus americanus"

subject: Manatus americanus

description and notes: lithograph; printed by Hanhart

article: Garrod, A.H. "Notes on the manatee

(Manatus americanus) recently living in the Society's Gardens." 10:137-145.

Plate 30: "Brain of Manatus americanus"

subject: Manatus americanus

description and notes: lithograph; printed by Hanhart

article: Garrod, A.H. "Notes on the manatee

(Manatus americanus) recently living in the Society's Gardens." 10:137-145.

Plate 31

subject: Dinornis crassus; Dinornis maximus description and notes: 1ithograph; printed by Hanhart; plate signed Smit del. et lith. article: Owen, [Professor]. "On Dinornis (Part XXI.): containing a restoration of the skeleton of Dinornis maximus, Owen. With an appendix, on additional evidence of the genus Dromornis in Australia." 10:147-188.

Plate 70: "Brain of Ceratorhinus sumatrensis [female]" subject: Ceratorhinus sumatrensis [female] description and notes: lithograph; printed by Hanhart

article: Garrod, A.H. "On the brain of the Sumatran rhinoceros (Ceratorhinus sumatrensis)." $10: 411-413$.

Plate 71

subject: Mesoplodon australis; Mesoplodon grayi; Mesoplodon haasti; Mesoplodon hectori description and notes: lithograph; printed by Hanhart

article: Flower, William Henry. "A further contribution to the knowledge of the existing ziphioid whales." 10:415-437. 
Plate 72

subject: Mesoplodon australis; Mesoplodon grayi; Mesoplodon haasti; Mesoplodon hectori description and notes: lithograph; printed by Hanhart

article: Flower, William Henry. "A further contribution to the knowledge of the existing ziphioid whales." 10:415-437.

\section{Plate 73}

subject: Mesoplodon grayi; Mesoplodon australis

description and notes: 1ithograph; printed by Hanhart; double-page plate

article: Flower, William Henry. "A further contribution to the knowledge of the existing ziphioid whales." 10:415-437.

Plate 89

subject: Crax globicera [female]

description and notes: chromolithograph; printed by M. \& N. Hanhart; plate signed J. Smit del. et lith.; figure shown $1 / 3$ natural size

article: Sclater, P.L. "Supplementary notes on the curassows now or lately living in the Society's Gardens." 10:543-546.

Plate 90

subject: Crax erythrognatha [male and female]

description and notes: chromolithograph; printed by M. \& N. Hanhart; plate signed J. Smit del. et lith.

article: Sclater, P.L. "Supplementary notes on the curassows now or lately living in the Society's Gardens." 10:543-546.

\section{Plate 91}

subject: Crax globulosa [female]

description and notes: hand-colored lithograph; printed by Hanhart; signed "J. Smit"

article: Sclater, P.L. "Supplementary notes on the curassows now or lately living in the Society's Gardens." 10:543-546.

Plate 92

subject: Crax viridirostris

description and notes: hand-colored lithograph; printed by M. \& N. Hanhart; plate signed J. Smit del. et lith.

article: Sclater, P.L. "Supplementary notes on the curassows now or lately living in the Society's Gardens." 10:543-546. 
Plate 93

subject: Crax incommoda

description and notes: hand-colored lithograph; printed by Hanhart; signed "J. Smit"

article: Sclater, P.L. "Supplementary notes on the curassows now or lately living in the Society's Gardens." 10:543-546.

Plate 94

subject: Crax urumutum

description and notes: hand-colored lithograph; printed by Hanhart; signed "J. Smit"

article: Sclater, P.L. "Supplementary notes on the curassows now or lately living in the Society's Gardens." 10:543-546.

Plate 95

subject: Crax salvini

description and notes: hand-colored lithograph; printed by Hanhart; signed "J. Smit"

article: Sclater, P.L. "Supplementary notes on the curassows now or lately living in the Society's Gardens." 10:543-546.

Volume 11 (1885)

Plate 1

subject: Delphinus delphis; Delphinus tursio description and notes: hand-colored lithograph; printed by Hanhart

article: Flower, William Henry. "On the external characteristics of two species of British dolphins (Delphinus delphis, Linn., and Delphinus tursio, Fabr.)." 11:1-5.

Plate 2

subject: Palorchestes crassus

description and notes: lithograph; printed by Hanhart

article: Owen, [Professor]. "Description of a portion of mandible and teeth of a large extinct kangaroo (Palorchestes crassus, Ow.) from ancient fluviatile drift, Queensland." 11:7-10.

Plate 3: "Brain of Hippopotamus"

subject: Hippopotamus amphibius

description and notes: lithograph; printed by Hanhart

article: Garrod, A.H. "On the brain and other parts of the hippopotamus (H. amphibius)." 11:11-17. 
Plate 4: "Brain of Hippopotamus"

subject: Hippopotamus amphibius

description and notes: lithograph; printed by Hanhart

article: Garrod, A.H. "On the brain and other parts of the hippopotamus (H. amphibius)." 11:11-17.

Plate 20

subject: Ceratorhinus sumatrensis

description and notes: lithograph; printed by Hanhart

article: Forbes, W.A. "On the male generative organs of the Sumatran rhinoceros (Ceratorhinus sumatrensis)." 11:107-109.

Plate 24

subject: Sepia palmata

description and notes: lithograph; printed by Hanhart; figure shown $3 / 4$ natural size

article: Owen, [Professor]. "Descriptions of some new and rare Cephalopoda. (Part II.).' $11: 131-170$.

Plate 25

subject: Sepia palmata

description and notes: lithograph; printed by Hanhart; figure shown $3 / 4$ natural size

article: Owen, [Professor]. "Descriptions of some new and rare Cephalopoda. (Part II.)." $11: 131-170$.

Plate 26

subject: Sepioteuthis brevis; Loligopsis ocellata

description and notes: lithograph; printed by Hanhart

article: Owen, [Professor]. "Descriptions of some new and rare Cephalopoda. (Part II.)." $11: 131-170$.

Plate 29

subject: Onychoteuthis raptor

description and notes: lithograph; printed by

Hanhart; figure shown natural size

article: Owen, [Professor]. "Descriptions of some new and rare Cephalopoda. (Part II.)."

$11: 131-170$.

Plate 30

subject: Enoploteuthis cookii

description and notes: lithograph; printed by Hanhart; figure shown natural size

article: Owen, [Professor]. "Descriptions of some new and rare Cephalopoda. (Part II.)."

$11: 131-170$. 
Plate 31

subject: Enoploteuthis cookii

description and notes: lithograph; printed by Hanhart; figure shown natural size and reduced article: Owen, [Professor]. "Descriptions of some new and rare Cephalopoda. (Part II.)." $11: 131-170$.

Plate 32

subject: Enoploteuthis cookii

description and notes: lithograph; printed by Hanhart; figure shown natural size

article: Owen, [Professor]. "Descriptions of some new and rare Cephalopoda. (Part II.)." $11: 131-170$.

Plate 33

subject: Enoploteuthis cookii; Architeuthis princeps

description and notes: lithograph; printed by Hanhart; figures shown reduced; plate incorrectly lists first species as "Enoploteathis cookii"

article: Owen, [Professor]. "Descriptions of some new and rare Cephalopoda. (Part II.)." 11: $131-170$.

Plate 48

subject: Otaria gillespii

description and notes: hand-colored lithograph; printed by Hanhart; signed "J. Smit"

article: Forbes, W.A. "Notes on the external characters and anatomy of the California sea-lion (Otaria gillespii)." 11:225-231.

Plate 49: "Head of Male Otaria gillespii" subject: Otaria gillespii [male]

description and notes: hand-colored lithograph; printed by Hanhart; figure shown $1 / 2$ natural size article: Forbes, W.A. "Notes on the external characters and anatomy of the California sea-lion (Otaria gillespii)." 11:225-231.

Plate 50

subject: Otaria gillespii

description and notes: lithograph; printed by Hanhart

article: Forbes, W.A. "Notes on the external characters and anatomy of the California sea-lion (Otaria gillespii)." 11:225-231. 
Volume 12 (1890)

Plate 33: "Sondaic Rhinoceros" subject: Rhinoceros sondaicus

description and notes: hand-colored lithograph; printed by Hanhart

article: Beddard, Frank E. and Frederick Treves.

"On the anatomy of the sondaic rhinoceros."

12:183-198.

Plate 34: "Sondaic Rhinoceros"

subject: Rhinoceros sondaicus

description and notes: hand-colored lithograph;

printed by Hanhart

article: Beddard, Frank E. and Frederick Treves.

"On the anatomy of the sondaic rhinoceros."

12:183-198.

Plate 35: "Sondaic Rhinoceros"

subject: Rhinoceros sondaicus

description and notes: lithograph; printed by Hanhart

article: Beddard, Frank E. and Frederick Treves. "On the anatomy of the sondaic rhinoceros."

$12: 183-198$.

Plate 36: "Sondaic Rhinoceros"

subject: Rhinoceros sondaicus

description and notes: hand-colored lithograph; printed by Hanhart

article: Beddard, Frank E. and Frederick Treves. "On the anatomy of the sondaic rhinoceros." $12: 183-198$.

Plate 37: "Sondaic Rhinoceros"

subject: Rhinoceros sondaicus

description and notes: lithograph; printed by Hanhart

article: Beddard, Frank E. and Frederick Treves. "On the anatomy of the sondaic rhinoceros." $12: 183-198$.

Plate 64

subject: Otaria hookeri

description and notes: hand-colored lithograph; printed by Hanhart; signed "J. Smit"

article: Beddard, Frank E. "On the structure of Hooker's sea-lion (Arctocephalus hookeri)." $12: 369-380$. 


\section{Plate 65}

subject: Otaria hookeri

description and notes: lithograph; printed by

Hanhart; shows foreflipper and hindflipper only; figures shown $1 / 2$ natural size

article: Beddard, Frank E. "On the structure of Hooker's sea-lion (Arctocephalus hookeri)." $12: 369-380$.

Volume 13 (1895)

Plate 20: "Head of Troglodytes calvus, Front View" subject: Troglodytes calvus

description and notes: lithograph; printed by Mintern Bros.; plate signed J. Smit del. et lith.; signed "J. Smit"; figure drawn after death, natural size

article: Beddard, Frank E. "Contributions to the anatomy of the anthropoid ape." 13:177-218.

Plate 21: "Head of Troglodytes calvus, From Above" subject: Troglodytes calvus

description and notes: lithograph; printed by Mintern Bros.; plate signed J. Smit del. et lith.; figure shown natural size article: Beddard, Frank E. "Contributions to the anatomy of the anthropoid ape." 13:177-218.

Plate 22: "Hand \& Foot of Troglodytes calvus" subject: Troglodytes calvus

description and notes: lithograph; printed by Mintern Bros.; plate signed J. Smit del. et lith.; folded plate; figure shown natural size article: Beddard, Frank E. "Contributions to the anatomy of the anthropoid ape." 13:177-218.

Plate 23: "Brain of Troglodytes calvus" subject: Troglodytes calvus

description and notes: lithograph; printed by Mintern Bros.; plate signed J. Smit del. et lith. article: Beddard, Frank E. "Contributions to the anatomy of the anthropoid ape." 13:177-218.

Plate 24: "Head of Orang" subject: Simia morio?

description and notes: hand-colored lithograph; printed by Mintern Bros.; plate signed J. Smit del. et lith.; signed "J. Smit" (in mirror image); figure shown natural size article: Beddard, Frank E. "Contributions to the anatomy of the anthropoid ape." 13:177-218. 
Plate 25: "Head of Orang, Palate of Chimpanzee \& Orang" subject: Simia morio?; Troglodytes calvus

description and notes: lithograph; printed by

Mintern Bros.; plate signed J. Smit del. et lith. article: Beddard, Frank E. "Contributions to the anatomy of the anthropoid ape." 13:177-218.

Plate 26: "Hand \& Foot of Orang, Back Aspect" subject: Simia morio?

description and notes: lithograph; printed by

Mintern Bros.; plate signed J. Smit del. et lith. article: Beddard, Frank E. "Contributions to the anatomy of the anthropoid ape." 13:177-218.

Plate 27: "Hand \& Foot of Orang, Front Aspect" subject: Simia morio?

description and notes: lithograph; printed by

Mintern Bros.; plate signed J. Smit del. et lith. article: Beddard, Frank E. "Contributions to the anatomy of the anthropoid ape." 13:177-218.

Plate 28: "Anatomy of Chimpanzees \& Orang" subject: Troglodytes calvus; Simia morio?

description and notes: lithograph; printed by

Mintern Bros.; plate signed J. Smit del. et lith. article: Beddard, Frank E. "Contributions to the anatomy of the anthropoid ape." 13:177-218.

Volume 14 (1898)

Plate 30

subject: Harpyionycteris whiteheadi;

Nannosciurus samaricus

description and notes: hand-colored lithograph; printed by Mintern Bros.; plate signed J. Smit del. et lith.; signed "j.' Smit"

article: Thomas, Oldfield. "On the mammals obtained by $\mathrm{Mr}$. John Whitehead during his recent

expedition to the Philippines." 14:377-412.

Plate 31

subject: Celaenomys silaceus; Rhynchomys soricoides

description and notes: hand-colored lithograph; printed by Mintern Bros.; plate signed J. Smit del. et lith.; signed "J. Smit"

article: Thomas, oldfield. "On the mammals obtained by Mr. John Whitehead during his recent

expedition to the Philippines." 14:377-412. 
Plate 32

subject: Chrytomys whiteheadi

description and notes: hand-colored lithograph; printed by Mintern Bros.; plate signed J. Smit del. et lith.; signed "J.' Smit"

article: Thomas, oldfield. "On the mammals obtained by Mr. John Whitehead during his recent

expedition to the Philippines." 14:377-412.

Plate 33

subject: Crunomys fallax; Batomys granti

description and notes: hand-colored lithograph; printed by Mintern Bros.; plate signed J. Smit del. et lith.; signed "J'. Smit"

article: Thomas, oldfield. "On the mammals obtained by Mr. John Whitehead during his recent

expedition to the Philippines." 14:377-412.

Plate 34

subject: Carpomys phaeurus; Carpomys melanurus description and notes: hand-colored lithograph; printed by Mintern Bros.; plate signed J. Smit del. et lith.; signed "J. Smit"

article: Thomas, Oldfield. "On the mammals obtained by $\mathrm{Mr}$. John Whitehead during his recent expedition to the Philippines." 14:377-412. 
SMIT, Peter

Volume $12(1890)$

Plate 7

subject: Lepidodactylus guppyi; Lipinia anolis;

Corucia zebrata; Hoplocephalus par

description and notes: hand-colored lithograph;

printed by Mintern Bros.; plate signed P. Smit

del. et lith.

article: Boulenger, G.A. "On the reptiles and

batrachians of the Solomon Islands." 12:35-62.

Plate 8

subject: Rana bufoniformis

description and notes: lithograph; printed by

Mintern Bros.; plate signed P. Smit del. et lith.

article: Boulenger, G.A. "On the reptiles and

batrachians of the Solomon Islands." 12:35-62.

Plate 9

subject: Rana guppyi

description and notes: lithograph; printed by

Mintern Bros.; plate signed P. Smit del. et lith. article: Boulenger, G.A. "On the reptiles and

batrachians of the Solomon Islands." 12:35-62.

Plate 10

subject: Rana opisthodon

description and notes: lithograph; printed by

Mintern Bros.; plate signed P. Smit del. et lith. article: Boulenger, G.A. "On the reptiles and

batrachians of the Solomon Islands." 12:35-62.

Plate 11

subject: Cornufer guppyi; Cornufer solomonis; Hyla macrops; Hyla thesaurensis

description and notes: lithograph; printed by

Mintern Bros.; plate signed P. Smit del. et lith. article: Boulenger, G.A. "On the reptiles and

batrachians of the Solomon Islands." 12:35-62. 


\section{Plate 12}

subject: Ceratobatrachus guentheri

description and notes: lithograph; printed by

Mintern Bros.; plate signed P. Smit del. et lith. article: Boulenger, G.A. "On the reptiles and

batrachians of the Solomon Islands." 12:35-62.

\section{Plate 13}

subject: Ceratobatrachus guentheri

description and notes: lithograph; printed by

Mintern Bros.; plate signed P. Smit del. et lith. article: Boulenger, G.A. "On the reptiles and

batrachians of the Solomon Islands." 12:35-62.

\section{Volume 13 (1895)}

\section{Plate 13}

subject: Saurodactylus mauritanicus;

Ptyodactylus lobatus var. oudrii; Tarentola mauritanica var. deserti; Agama tournevillii

description and notes: lithograph; printed by Mintern Bros.; plate signed Peter Smit del. et lith.

article: Boulenger, G.A. "Catalogue of the reptiles and batrachians of Barbary (Morocco, Algeria, Tunisia), based chiefly upon the notes and collections made in 1880-1884 by M. Fernand Lataste." 13:93-164.

Plate 14

subject: Agama bibronii; Psammodromus blanci description and notes: lithograph; printed by Mintern Bros.; plate signed Peter Smit del. et lith.

article: Boulenger, G.A. "Catalogue of the reptiles and batrachians of Barbary (Morocco, Algeria, Tunisia), based chiefly upon the notes and collections made in 1880-1884 by $M$. Fernand Lataste." 13:93-164.

\section{Plate 15}

subject: Lacerta ocellata

description and notes: lithograph; printed by Mintern Bros.; plate signed Peter Smit del. et lith.

article: Boulenger, G.A. "Catalogue of the reptiles and batrachians of Barbary (Morocco, Algeria, Tunisia), based chiefly upon the notes and collections made in 1880-1884 by M. Fernand Lataste." 13:93-164. 
Plate 16

subject: Eumeces algeriensis

description and notes: lithograph; printed by Mintern Bros.; plate signed Peter Smit del. et lith.

article: Boulenger, G.A. "Catalogue of the reptiles and batrachians of Barbary (Morocco, Algeria, Tunisia), based chiefly upon the notes and collections made in 1880-1884 by $M$. Fernand Lataste." 13:93-164.

Plate 17

subject: Chalcides ocellatus var. vittatus;

Chalcides ocellatus var. polylepis;

Chalcides lineatus

description and notes: lithograph; printed by Mintern Bros.; plate signed Peter Smit del. et lith.

article: Boulenger, G.A. "Catalogue of the reptiles and batrachians of Barbary (Morocco, Algeria, Tunisia), based chiefly upon the notes and collections made in $1880-1884$ by M. Fernand Lataste." 13:93-164.

Plate 18

subject: Coronella amaliae; Cerastes vipera; Salamandra maculosa var. Algira; Molge hagenmuelleri

description and notes: lithograph; printed by Mintern Bros.; plate signed Peter Smit del. et lith.

article: Boulenger, G.A. "Catalogue of the reptiles and batrachians of Barbary (Morocco, Algeria, Tunisia), based chiefly upon the notes and collections made in $1880-1884$ by $M$. Fernand Lataste." 13:93-164. 
Volume 14 (1898)

Plate 37

subject: Lepidosiren paradoxa

description and notes: lithograph; printed by Mintern Bros.; two-page plate article: Goeldi, Emil A. "On the Lepidosiren of the Amazons; being notes on five specimens obtained between 1895-97, and remarks upon an example living in the Para Museum." 14:413-420.

Plate 38: "Evolutions of the Living Lepidosiren paradoxa"

subject: Lepidosiren paradoxa

description and notes: lithograph; printed by Mintern Bros.

article: Goeldi, Emil A. "On the Lepidosiren of the Amazons; being notes on five specimens obtained between 1895-97, and remarks upon an example living in the Para Museum." 14:413-420.

Volume 16 (1903)

Plate 30: "The Okapi (Okapia johnstoni)" subject: Okapia johnstoni description and notes: hand-colored lithograph; printed by Mintern Bros.; plate signed P.J. Smit del. et lith.

article: Lankester, E. Ray. "On Okapia, a new genus of Giraffidae, from Central Africa." $16: 279-314$. 
SMITH, Edgar Albert (1847-1916)

\section{Volume 5 (1866)}

\section{Plate 51}

subject: Alca impennis; Uria grylle

description and notes: lithograph; printed by $W$. West; plate signed E.A. Smith del. \& lith.

article: Owen, [Professor]. "Description of the skeleton of the great auk, or garfowl (Alca impennis, L.)." $\xi: 317-335$.

\section{Plate 52}

subject: Alca impennis; Uria grylle

description and notes: lithograph; printed by $W$. West; plate signed E.A. Smith del. \& lith.

article: Owen, [Professor]. "Description of the skeleton of the great auk, or garfowl (Alca impennis, L.)." 5:317-335.

\section{Volume 9 (1877)}

Plate 94: "New Species of Sphingidae" subject: Chaerocampa docilis Butler; Chaerocampa virescens Butler; Nephele rosae Butler; Diludia melanomera Butler; Diludia natalensis Butler; Amphonyx rivularis Butler; Isognathus metascyron Butler; Isognathus amazonicus Butler

description and notes: hand-colored lithograph; printed by Mintern Bros.; plate signed E.A. Smith del. et lith.

article: Butler, Arthur Gardiner. "Revision of the heterocerous Lepidoptera of the family Sphingidae." 9:511-644. 
SOWERBY, George Brettingham

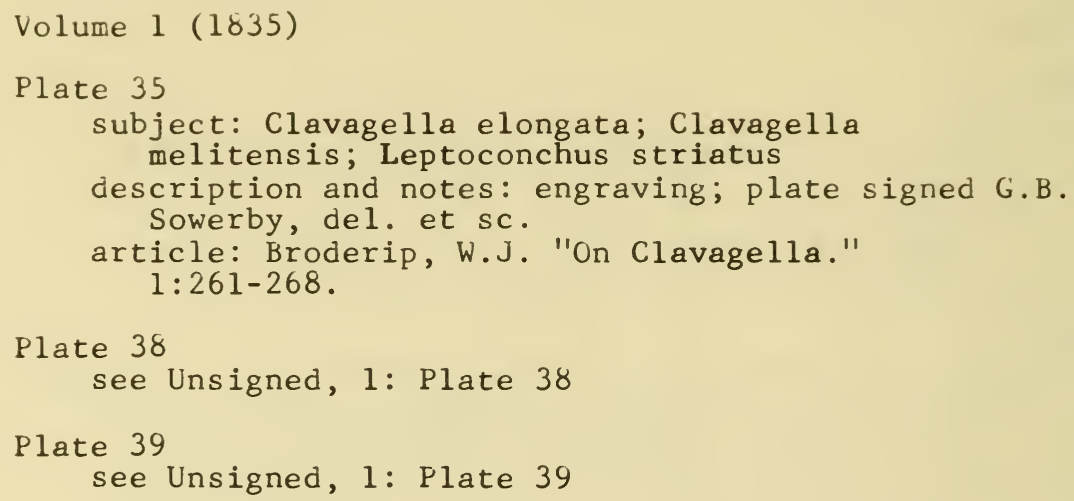


SOWERBY, George Brettingham, Jr. (1812-1884)

\section{Volume 1 (1835)}

Plate 22: Terebratula see Owen, v. 1 (1835): Plate 22

Plate 23: Orbicula \& Lingula see Owen, v. 1 (1835): Plate 23

Plate 27: Calyptraea

subject: Calyptraea rudis; Calyptraea corrugata; Calyptraea varia; Calyptraea cepacea; Calyptraea cornea; Calyptraea radiata; Calyptraea imbricata; Calyptraea lignaria; Calyptraea tenuis; Calyptraea hispida; Calyptraea maculata description and notes: hand-colored engraving; plate signed G.B. Sowerby, Jun. del. \& sculp. article: Broderip, W.J. "Description of some neh species of Calyptraeidae." 1:195-206.

Plate 28: Calyptraea

subject: Calyptraea serrata; Calyptraea sordida; Calyptraea unguis; Calyptraea lichen; Calyptraea mamillaris; Calyptraea striata; Calyptraea conica; Calyptraea spinosh; Calyptraea foliacea; Calyptraea dorsata; Calyptraea dilatata, Lam.; Calyptraea strigata

description and notes: hand-colored engraving; plate signed G.B. Sowerby, Jun. del. \& sculp. article: Broderip, W.J. "Description of some new species of Calyptraeidae." 1:195-206.

Plate 29: Calyptraea

subject: Calyptraea echinus; Calyptraea hystrix; Calyptraea pallida; Calyptraea unguiformis, Lam.; Calyptraea lessonii; Calyptraea incurva; Calyptraea excavata; Calyptraea arenata; Calyptraea marginalis; Calyptraea squama

description and notes: hand-colored engraving; plate signed G.B. Sowerby, Jun. del. \& sculp. article: Broderip, W.J. "Description of some new species of Calyptraeidae." 1:195-206. 
Plate 47: Cancer

subject: Cancer longipes; Cancer edwardsii;

Cancer dentatus; Cancer irroratus; Cancer pagurus

description and notes: engraving; plate signed G.B. Sowerby, Junr. del. et sc.

article: Bell, Thomas. "Observations on the genus

Cancer of Dr. Leach (Platycarcinus, Latr.,), with descriptions of three new species." $1: 335-342$.

Volume $3(1849)$

Plate 13

subject: Euplectella aspergillum, Owen

description and notes: engraving; plate signed G.B. Sowerby Junr. Delt. et Sculpt.

article: Owen, Richard. "Description of a new genus and species of sponge (Euplectella aspergillum, 0.)" 3:203-205. 


\section{STEBBING, Thomas K.k. (1835-1926)}

Volume $12(1890)$

Plate 16: "Crustacea Isopoda" subject: Apseudes latreillii

description and notes: lithograph; printed by Hanhart

article: Norman, A.M. and T.R.R. Stebbing. "On the

Crustacea Isopoda of the 'Lightning,

'Porcupine,' and 'Valorous' Expeditions." $12: 77-141$.

Plate 17: "Crustacea Isopoda" subject: Apseudes spinosus; Apseudes lunarifrons description and notes: lithograph; printed by Hanhart

article: Norman, A.M. and T.R.R. Stebbing. "On the Crustacea Isopoda of the 'Lightning,

'Porcupine,' and 'Valorous' Expeditions." $12: 77-141$.

Plate 18: "Crustacea Isopoda"

subject: Apseudes simplicirostris; Apseudes obtusifrons

description and notes: lithograph; printed by Hanhart

article: Norman, A.M. and T.R.R. Stebbing. "On the Crustacea Isopoda of the 'Lightning, 'Porcupine,' and 'Valorous' Expeditions." $12: 77-141$.

Plate 19: "Crustacea Isopoda" subject: Apseudes grossimanus

description and notes: lithograph; printed by Hanhart

article: Norman, A.M. and T.R.R. Stebbing. "On the Crustacea Isopoda of the 'Lightning,

'Porcupine,' and 'Valorous' Expeditions." $12: 77-141$. 
Plate 20: "Crustacea Isopoda"

subject: Apseudes gracilis

description and notes: lithograph; printed by Hanhart

article: Norman, A.M. and T.R.R. Stebbing. "On the Crustacea Isopoda of the 'Lightning,

'Porcupine,' and 'Valorous' Expeditions." $12: 77-141$.

Plate 21: "Crustacea Isopoda"

subject: Apseudes uncidigitatus; Apseudes anomalus

description and notes: lithograph; printed by Hanhart

article: Norman, A.M. and T.K.K. Stebbing. "On the Crustacea Isopoda of the 'Lightning,

'Porcupine,' and 'Valorous' Expeditions." $12: 77-141$.

Plate 22: "Crustacea Isopoda"

subject: Sphyrapus tudes; Sphyrapus malleolus [male and female]

description and notes: lithograph; printed by Hanhart

article: Norman, A.M. and T.K.R. Stebbing. "On the Crustacea Isopoda of the 'Lightning,'

'Porcupine,' and 'Valorous' Expeditions." $12: 77-141$.

Plate 23: "Crustacea Isopoda"

subject: Alaotanais serratispinosus; Alaotanais hastiger

description and notes: lithograph; printed by Hanhart

article: Norman, A.M. and T.R.R. Stebbing. "On the Crustacea Isopoda of the 'Lightning,

'Porcupine,' and 'Valorous' Expeditions." $12: 77-141$.

Plate 24: "Crustacea Isopoda"

subject: Alaotanais serratispinosus; Alaotanais

laevispinosus; Strongylura arctiphylax;

Tanaella unguicillata

description and notes: lithograph; printed by Hanhart

article: Norman, A.M. and T.R.R. Stebbing. "On the Crustacea Isopoda of the 'Lightning, 'Porcupine,' and 'Valorous' Expeditions." $12: 77-141$. 
Plate 25: "Crustacea Isopoda"

subject: Anthelura elongata [male and female]; Anthura gracilis [male and female]; Hyssura producta

description and notes: lithograph; printed by Hanhart

article: Norman, A.M. and T.K.K. Stebbing. "On the Crustacea Isopoda of the 'Lightning,'

'Porcupine,' and 'Valorous' Expeditions." $12: 77-141$.

Plate 26: "Crustacea Isopoda"

subject: Calathura brachiata; Paranthura nigro-punctata

description and notes: lithograph; printed by Hanhart

article: Norman, A.M. and T.R.R. Stebbing. "On the Crustacea Isopoda of the 'Lightning,'

'Porcupine,' and 'Valorous' Expeditions." $12: 77-141$.

Plate 27: "Crustacea Isopoda"

subject: Paranthura tenuis; Anthelura abyssorum; Cyathura carinata

description and notes: lithograph; printed by Hanhart

article: Norman, A.M. and T.R.R. Stebbing. "On the Crustacea Isopoda of the 'Lightning,

'Porcupine,' and 'Valorous' Expeditions." $12: 77-141$.

Plate 38: "New Exotic Amphipoda"

subject: Byblis kallarthrus

description and notes: lithograph; printed by Hanhart

article: Stebbing, Thomas R.K. "Un some new exotic Amphipoda from Singapore and New Zealand."

12:199-210.

Plate 39: "New Exotic Amphipoda"

subject: Talorchestia tumida; Pherusa caerulea description and notes: lithograph; printed by Hanhart

article: Stebbing, Thomas R.R. "On some new exotic Amphipoda from Singapore and New Zealand." $12: 199-210$. 
Volume 13 (1895)

Plate 1

subject: Urothoe elegans Sp. Bate

description and notes: lithograph; plate signed Del. T.R.R. Stebbing, J.T. Rennie Reid Lith. Edinr.

article: Stebbing, Thomas R.R. "On the genus

Urothoe and a new genus Urothoides." 13:1-30.

Plate 2

subject: Urothoe marinus Sp. Bate

description and notes: lithograph; plate signed

Del. T.R.R. Stebbing, J.T. Rennie Reid Lith.

Edinr.

article: Stebbing, Thomas R.R. "On the genus

Urothoe and a new genus Urothoides." 13:1-30.

Plate 3

subject: Urothoe brevicornis Sp. Bate

description and notes: lithograph; plate signed

Del. T.R.R. Stebbing, J.T. Rennie Reid Lith.

Edinr.

article: Stebbing, Thomas R.R. "On the genus

Urothoe and a new genus Urothoides." 13:1-30.

Plate 4

subject: Urothoe pulchella Costa [female];

Urothoe norvegica Boeck; Urothoe brevicornis

Sp. Bate [female]

description and notes: lithograph; plate signed

Del. T.R.R. Stebbing, J.T. Rennie Reid Lith.

Edinr.

article: Stebbing, Thomas R.R. "On the genus

Urothoe and a new genus Urothoides." 13:1-30.

Plate 5

subject: Sophrosyne robertsoni; Syrrhoë fimbriatus

description and notes: lithograph; plate signed

Del. T.R.R. Stebbing, J.T. Rennie Reid Lith.

Edinr.

article: Stebbing, Thomas R.R. and David Robertson.

"On four new British Amphipoda." 13:31-42.

Plate 6

subject: Podoceropsis palmatus; Podocerus cumbrensis

description and notes: lithograph; plate signed

Del. T.R.R. Stebbing, J.T. Rennie Reid Lith.

Edinr.

article: Stebbing, Thomas R.R. and David Robertson. "On four new British Amphipoda." 13:31-42. 
Plate 51

subject: Scina acanthodes

description and notes: lithograph; printer not given on plate

article: Stebbing, Thomas R.R. "Descriptions of nine new species of amphipodous crustaceans from the tropical Atlantic." 13:349-371.

Plate 52

subject: Scina stenopus; Scina oedicarpus

description and notes: 1ithograph; printer not given on plate

article: Stebbing, Thomas R.R. "Descriptions of nine new species of amphipodous crustaceans from the tropical Atlantic." 13:349-371.

Plate 53

subject: Scina rattrayi; Scina concors

description and notes: lithograph; printer not given on plate

article: Stebbing, Thomas R.R. "Descriptions of nine new species of amphipodous crustaceans from the tropical Atlantic." 13:349-371.

Plate 54

subject: Scina similis; Scina uncipes

description and notes: lithograph; printer not given on plate

article: Stebbing, Thomas R.R. "Descriptions of nine new species of amphipodous crustaceans from the tropical Atlantic." 13:349-371.

Plate 55

subject: Rhabdosoma piratum; Rhabdosoma brachyteles

description and notes: 1ithograph; printer not given on plate

article: Stebbing, Thomas R.R. "Descriptions of nine new species of amphipodous crustaceans from the tropical Atlantic." 13:349-371.

Volume 20 (1912-1915)

$\mathrm{Pl}$ ate 24

subject: Gnathia cristatipes; Gnathia schistifrons

description and notes: lithograph; printed by $E$. Wilson; plate signed T.R.R. Stebbing del., M.P. Parker lith.

article: Stebbing, T.R.R. "On the Crustacea Isopoda of the 'Porcupine' Expedition." 20:231-246. 
Plate 25

subject: Akidognathia oedipus

description and notes: lithograph; printed by $E$. Wilson; plate signed T.R.R. Stebbing del., M.P. Parker lith.

article: Stebbing, T.R.R. "On the Crustacea Isopoda of the 'Porcupine' Expedition." 20:231-246.

Plate 26

subject: Thambema amicorum

description and notes: lithograph; printed by $E$. Wilson; plate signed T.R.R. Stebbing del., M.P. Parker lith.

article: Stebbing, T.R.R. "On the Crustacea Isopoda of the "Porcupine' Expedition." 20:231-246. 
STONE, A.

\section{Volume 11 (1885)}

Plate 81: "Anatomy of Scorpio"

subject: Scorpio italicus; Androctonus

funestus; Scorpio (Buthus) cyaneus;

Euscorpius italicus; Brotheas subnitens;

Telegonus

description and notes: 1ithograph; printed by

Hanhart; plate signed A. Stone del., C. Berjeau lith.

article: Lankester, E. Ray, W.B.S. Benham and E.J. Beck. "On the muscular and endoskeletal systems of Limulus and Scorpio; with some notes on the anatomy and generic characters of scorpions." 11:311-384.

Plate 82: "Anatomy of Scorpio"

subject: Buthus cyaneus; Prionurus funestus;

Euscorpius italicus; Telegonus; Centrurus

americanus; Centrurus hottentotus

description and notes: lithograph; printed by

Hanhart; plate signed A. Stone del., C. Berjeau lith.

article: Lankester, E. Ray, W.B.S. Benham and E.J.

Beck. "On the muscular and endoskeletal systems

of Limulus and Scorpio; with some notes on

the anatomy and generic characters of

scorpions." 11:311-384.

Plate 83: "Anatomy of Scorpio"

subject: Androctonus (Prionurus) funestus;

Euscorpius italicus Roes.

description and notes: lithograph with printed color background; printed by Hanhart; plate signed A. Stone del., C. Berjeau lith.

article: Lankester, E. Ray, W.B.S. Benham and E.J. Beck. "On the muscular and endoskeletal systems of Limulus and Scorpio; with some notes on the anatomy and generic characters of scorpions." 11:311-384. 


\section{SUSINI, T. [f].1860-1880]}

Volume 6 (1869)

Plate 75

subject: Heros lobochilus; Heros erythraeus

description and notes: lithograph; printed by $W$. West

article: Günther, Albert. "An account of the fishes of the states of Central America, based on collections made by Capt. J.M. Dow F. Godman, Esq., and O. Salvin, Esq." 6:377-494. 


\section{SWAINE, J .}

Volume 3 (1849)

Plate 12

see Unsigned, 3: Plate 12 
Volume 16 (1903)

Plate 1: "Sphenodon punctatus. Vertebral Column \& Ribs"

subject: Sphenodon punctatus

description and notes: hand-colored lithograph; printed by Geo. West \& Sons; plate signed H.H.S. del., M.P. Parker lith.

article: Howes, G.B. and H.H. Swinnerton. "On the development of the skeleton of the tuatara, Sphenodon punctatus; with remarks on the egg, on the hatching, and on the hatched young. $16: 1-86$.

Plate 2: "Sphenodon punctatus. Vertebral Column \& Ribs, Gastralia \& Teeth"

subject: Sphenodon punctatus

description and notes: hand-colored lithograph; printed by Geo. West \& Sons; plate signed H.H.S. del., M.P. Parker lith.

article: Howes, G.B. and H.H. Swinnerton. "On the development of the skeleton of the tuatara, Sphenodon punctatus; with remarks on the egg, on the hatching, and on the hatched young. $16: 1-86$.

Plate 3: "Sphenodon punctatus. Developing skull, earlier stages"

subject: Sphenodon punctatus

description and notes: hand-colored lithograph; printed by Geo. West \& Sons; plate signed H.H.S. del., M.P. Parker lith.

article: Howes, G.B. and H.H. Swinnerton. "On the development of the skeleton of the tuatara, Sphenodon punctatus; with remarks on the egg, on the hatching, and on the hatched young. $16: 1-86$. 
Plate 4: "Sphenodon punctatus. Developing skull,
later stages" subject: Sphenodon punctatus

description and notes: hand-colored lithograph; printed by Geo. West \& Sons; plate signed H.H.S. del., M.P. Parker lith.

article: Howes, G.B. and H.H. Swinnerton. "On the development of the skeleton of the tuatara, Sphenodon punctatus; with remarks on the egg, on the hatching, and on the hatched young. "I $16: 1-86$.

Plate 5: "Sphenodon punctatus. The Quadrate, Hyoid, \& Columella auris"

subject: Sphenodon punctatus

description and notes: hand-colored lithograph; printed by Geo. West \& Sons; plate signed H.H.S. del., M.P. Parker lith.

article: Howes, G.B. and H.H. Swinnerton. "On the development of the skeleton of the tuatara, Sphenodon punctatus; with remarks on the egg, on the hatching, and on the hatched young. $16: 1-86$.

Plate 6: "Sphenodon punctatus. Cranio-facial membrane bones, \& Appendicular Skeleton"

subject: Sphenodon punctatus

description and notes: hand-colored lithograph; printed by Geo. West \& Sons; plate signed H.H.S. del., M.P. Parker 1ith.

article: Howes, G.B. and H.H. Swinnerton. "On the development of the skeleton of the tuatara, Sphenodon punctatus; with remarks on the egg, on the hatching, and on the hatched young." $16: 1-86$. 
Volume 2 (1841)

Plate 5

subject: Actinia sanguineo-punctata; Kenia desjardiniana; Anisomelus luteus; Piratesa nigio-annulota

description and notes: hand-colored engraving;

plate signed R. Templeton del., Swaine Sc.

article: Templeton, Robert. "Descriptions of a few invertebrated animals obtained at the Isle of France." 2:25-30. 
TERZI, Amadeo John Engel (1872-1956?)

Volume 19 (1909-1910)

Plate 3: "Diptera" subject: Tabanus ruwenzorii Ricardo; Proagonistes praedo Austen; Syrphus adligatus Wied.; Asarcina amaena Austen; Asarcina punctifrons Austen; Senaspis aesacus Walk.; Senaspis elliotii Austen; Megaspis bulligera Austen; Dejeania wollastonii Austen; Sericophoromyia claripilosa Austen; Dexia inappendiculata Austen; Sarcophaga notatipennis Austen; Sarcophaga inaequalis Austen

description and notes: chromolithograph; printer not noted on plate

article: Austen, Ernest E. "Ruwenzori Expedition reports. 10. Diptera." 19:85-102. 
Volume 4 (1862)

Plate 5

subject: Nautilus pompilius

description and notes: lithograph; printed by Hullmandel \& Walton; plate signed Van den [sic] Hoven [sic] del., W. Wing, lith.; shows cutaway of shell, revealing animal

article: Van der Hoeven, J. "Contributions to the knowledge of the animal of Nautilus pompilius." $4: 21-29$.

Plate 6

subject: Nautilus pompilius

description and notes: lithograph; printed by Hullmandel \& Walton; plate signed Van der Hoven [sic] del., W. Wing, lith.

article: Van der Hoeven, J. "Contributions to the knowledge of the animal of Nautilus pompilius." 4:21-29.

Plate 7

subject: Nautilus pompilius

description and notes: lithograph; printed by Hullmandel \& Walton; plate signed Van der Hoeven del., W. Wing, lith.

article: Van der Hoeven, J. "Contributions to the knowledge of the animal of Nautilus pompilius." $4: 21-29$.

Plate 8

subject: Nautilus pompilius

description and notes: lithograph; printed by

Hullmandel \& Walton; plate signed Van der Hoven [sic] del., W. Wing, Iith.

article: Van der Hoeven, J. "Contributions to the knowledge of the animal of Nautilus pompilius." 4:21-29. 
VINCENT, Swale (b. 1868)

Volume 14 (1898)

Plate 9: "Supra-Renal Bodies in Fishes"

subject: Chimaera monstrosa; Scyllium canicula [female]; Scyllium catulus

description and notes: lithograph; printed by Geo. West \& Sons; plate signed Swale Vincent del., M.P. Parker lith.

article: Vincent, Swale. "Contributions to the comparative anatomy and histology of the suprarenal capsules. The suprarenal bodies in fishes and their relation to the so-called head-kidney." 14:41-84.

Plate 10: "Supra-Renal Bodies in Fishes" subject: Acanthias vulgaris; Raja batis; Raja maculata; Acipenser sturio; Orthagoriscus mola; Conger conger; Clupea harengus

description and notes: lithograph; printed by Geo. West \& Sons; plate signed Swale Vincent del., M.P. Parker lith.

article: Vincent, Swale. "Contributions to the comparative anatomy and histology of the suprarenal capsules. The suprarenal bodies in fishes and their relation to the so-called head-kidney." 14:41-84.

Plate 11: "Supra-Renal Bodies in Fishes" subject: Esox lucius; Salmo salar; Osmerus eperlanus; Leuciscus rutilis; Leuciscus cephalus; Leuciscus vulgaris; Gadus morrhua; Gadus aeglefinus; Merluccius vulgaris; Molva vulgaris; Pleuronectes flesus; Pleuronectes limanda; Pleuronectes platessa

description and notes: lithograph; printed by Geo. West \& Sons; plate signed Swale Vincent del., M.P. Parker lith.

article: Vincent, Swale. "Contributions to the comparative anatomy and histology of the suprarenal capsules. The suprarenal bodies in fishes and their relation to the so-called head-kidney." 14:41-84. 
Plate 12: "Supra-Renal Bodies in Fishes"

subject: Hippoglossus vulgaris; Hippoglossoides limandoides; Solea vulgaris; Rhombus

laevis; Perca fluviatilis; Mullus barbatus;

Pagellus centrodontus; Cottus gobio; Trigla pini; Trigla lyra; Scomber scomber; Zeus

faber; Anarrhinchas lupus; Lophius piscatorius

description and notes: lithograph; printed by Geo. West \& Sons; plate signed Swale Vincent del., M.P. Parker lith.

article: Vincent, Swale. "Contributions to the comparative anatomy and histology of the suprarenal capsules. The suprarenal bodies in fishes and their relation to the so-called head-kidney." 14:41-84.

Plate 13: "Supra-Renal Bodies in Fishes"

subject: Mugil capito; Cyclopterus lumpus;

Acanthias vulgaris; Scyllium canicula; Raja clavata

description and notes: lithograph; printed by Geo. West \& Sons; plate signed Swale Vincent del., M.P. Parker lith.

article: Vincent, Swale. "Contributions to the comparative anatomy and histology of the suprarenal capsules. The suprarenal bodies in fishes and their relation to the so-called head-kidney." 14:41-84.

Plate 14: "Supra-Renal Bodies in Fishes"

subject: Acipenser sturio; Conger conger;

Anarrhichas lupus; Pleuronectes limanda;

Mullus barbatus

description and notes: lithograph; printed by Geo. West \& Sons; plate signed Swale Vincent del., M.P. Parker lith.

article: Vincent, Swale. "Contributions to the comparative anatomy and histology of the suprarenal capsules. The suprarenal bodies in fishes and their relation to the so-called head-kidney." 14:41-84. 


\section{VISUISF, Djrowcz}

\section{Volume $3(1849)$}

Plate 27

subject: Dinornis giganteus; Dinornis struthoides; Dinornis didiformis

description and notes: lithograph; printed by C. Hullmandel; plate signed Lithog. from Nature by Djrowcz Visoisf; figures shown natural size; double-page folded plate

article: Owen, [Professor]. "On Dinornis, an extinct genus of tridactyle struthious birds, with descriptions of portions of the skeleton of five species which formerly existed in New Zealand." $3: 235-275$. 
VOGEL, Friedrich Carl (d. 1865)

Volume 3 (1849)

Plate 16

subject: Chizaerhis personata, Rüppell

description and notes: hand-colored lithograph;

plate signed F.C. Vogel del., BWH lithog.;

figure shown $1 / 2$ natural size

article: Rüppell, Eduard. "Mémoire sur la famille des Touracos, et déscription de deux espèces nouvelles." 3:231-233.

Plate 17

subject: Chizaerhis leucogaster, Rüppel1

description and notes: hand-colored lithograph;

plate signed F.C. Vogel del., BWH 1ithog.; figure shown $1 / 2$ natural size

article: Rüppe11, Eduard. "Mémoire sur la famille des Touracos, et déscription de deux espèces nouvelles." $3: 231-233$. 
WAGNER, F.

\section{Volume 7 (1872)}

\section{Plate 48}

subject: Pectinator spekei

description and notes: hand-colored lithograph; printed by $M$. \& N. Hanhart; plate signed $F$. Wagner del. et lith.

article: Peters, W. "Contributions to the knowledge of Pectinator, a genus of rodent Mammalia from north-eastern Africa." 7:397-409.

\section{Plate 49}

subject: Pectinator spekei

description and notes: lithograph; printed by M. \& $\mathrm{N}$. Hanhart; plate signed $\mathrm{F}$. Wagner del. et lith.; shows skeleton only

article: Peters, $W$. "Contributions to the knowledge of Pectinator, a genus of rodent Mammalia from north-eastern Africa." 7:397-409.

Plate 50

subject: Ctenodactylus massonii, Gray;

Pectinator spekii

description and notes: lithograph; printed by $\mathrm{M}$. \& $N$. Hanhart; plate signed $F$. Wagner del. et lith.; shows anatomical details

article: Peters, W. "Contributions to the knowledge of Pectinator, a genus of rodent liammalia from north-eastern Africa." 7:397-409. 
WATERHOUSE, George Robert (1810-1888)

Volume 2 (1841)

Plate 28

subject: Myrmecobius fasciatus

description and notes: engraving; plate signed Geo: $\mathrm{R}$. Waterhouse delt., Swaine sc.; shows details of anatomy

article: Waterhouse, George K. "Description of a new genus of mammiferous animals from Australia, belonging probably to the order Marsupialia." $2: 149-154$.

Plate 58

see Curtis, 2: Plate 58 


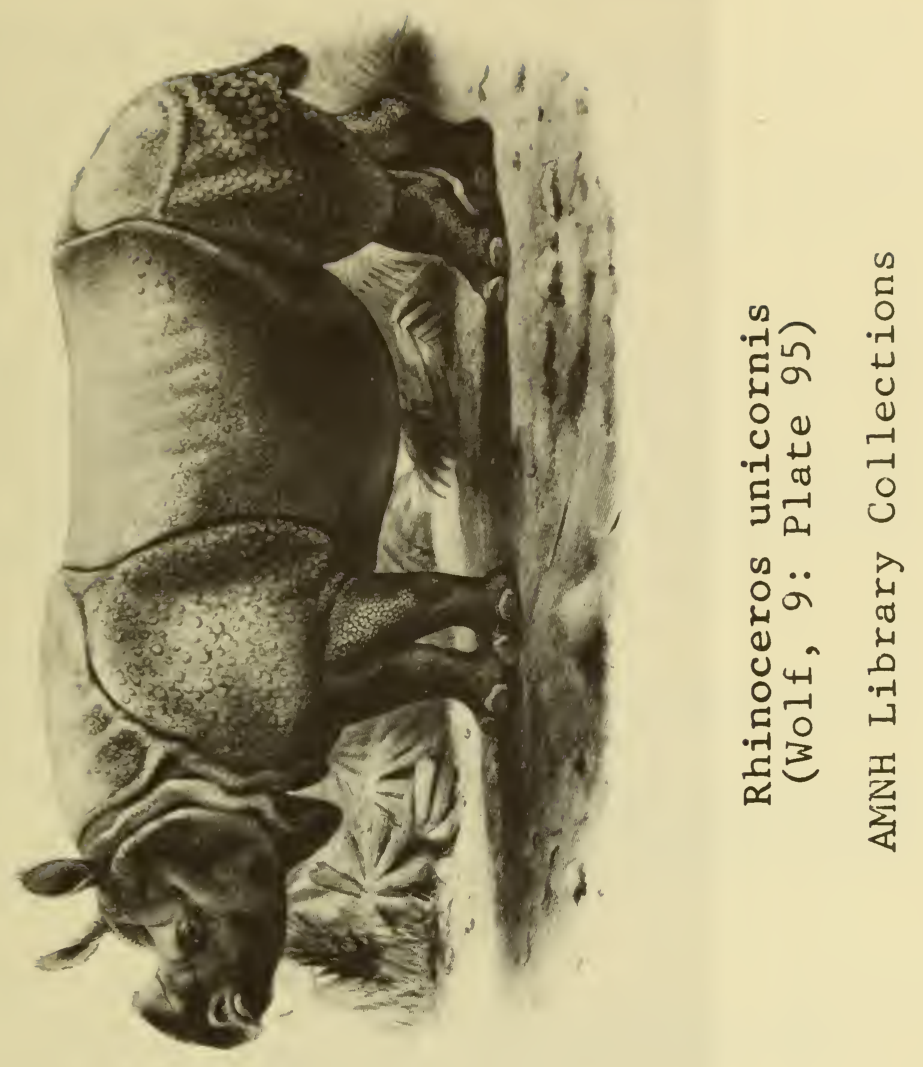





\section{WESLEY, William Henry [fl. 1670s/1680]}

\section{Volume 6 (1869)}

\section{Plate 35}

subject: Simia

description and notes: lithograph; printed by M. \&

N. Hanhart; plate signed W.H. Wesley del. et

lith.; double-page folded plate

article: Mivart, St. George. 'Contributions towards a more complete knowledge of the skeleton of the primates. Part I. The appendicular skeleton of Simia." 6:175-225.

Plate 36

subject: Simia

description and notes: lithograph; printed by $\mathbb{M}$. \&

N. Hanhart; plate signed W.H. Wesley del. et

lith.; double-page folded plate

article: Mivart, St. George. "Contributions towards

a more complete knowledge of the skeleton of the primates. Part I. The appendicular skeleton of Simia." $6: 175-225$.

\section{Plate 37}

subject: Simia

description and notes: 1ithograph; printed by M. \&

N. Hanhart; plate signed W.H. Wesley delt. et

lith.; double-page folded plate

article: Mivart, St. George. "Contributions towards

a more complete knowledge of the skeleton of the primates. Part I. The appendicular skeleton of Simia." 6:175-225.

Plate 38

\section{subject: Simia}

description and notes: 1ithograph; printed by $\mathbf{M}$. \&

N. Hanhart; plate signed W.H. Wesley del. et

lith.; double-page folded plate

article: Mivart, St. George. "Contributions towards

a more complete knowledge of the skeleton of the primates. Part I. The appendicular skeleton of

Simia." $6: 175-225$. 


\section{Plate 39}

subject: Simia

description and notes: lithograpt $;$ printed by $M$. \& N. Hanhart; plate signed W.H. Wesley del. et lith.; double-page folded plate

article: Mivart, St. George. 'Contributions towards a more complete knowledge of the skeleton of the primates. Part I. The appendicular skeleton of Simia." 6:175-225.

\section{Plate 40}

subject: Simia

description and notes: lithograph; printed by M. \& N. Hanhart; plate signed W.H. Wesley del. et lith.; double-page folded plate

article: Mivart, St. George. 'Contributions towards a more complete knowledge of the skeleton of the primates. Part I. The appendicular skeleton of Simia." $6: 175-22 \dot{5}$.

\section{Plate 41}

subject: Simia

description and notes: lithograph; printed by $\mathrm{M}$. \& N. Hanhart; plate signed W.H. Wesley delt. et lith.; double-page folded plate

article: Mivart, St. George. "Contributions towards a more complete knowledge of the skeleton of the primates. Part I. The appendicular skeleton of Simia." $6: 175-225$.

\section{Plate 42}

subject: Simia

description and notes: lithograph; printed by M. \& N. Hanhart; plate signed W.H. Wesley del. et lith.; double-page folded plate

article: Mivart, St. George. "Contributions towards a more complete knowledge of the skeleton of the primates. Part I. The appendicular skeleton of Simia." $6: 175-225$.

\section{Plate 43}

subject: Simia

description and notes: 1ithograph; printed by M. \& N. Hanhart; plate signed W.H. Wesley del. et lith.; double-page folded plate

article: Mivart, St. George. "Contributions towards a more complete knowledge of the skeleton of the primates. Part I. The appendicular skeleton of Simia." 6:175-225. 
Volume 8 (1874)

Plate 2

subject: Grampus griseus

description and notes: lithograph; printed by Maclure \& Macdonald; shows articulated skeletons; tigures shown $1 / 8$ natural size; two-page plate

article: Flower, William Henry. "On Risso's dolphin, Grampus griseus (Cuv.)." 8:1-21.

Piate 27

subject: Berardius arnouxi

description and notes: 1ithograph; printed by Maclure \& Macdonald; shows articulated skeletons; figures shown $1 / 16$ natural size; three-page folded plate

article: Flower, William Henry. "On the recent ziphioid whales, with a description of the skeleton of Berardius arnouxi." 8:203-234.

Plate 28

subject: Berardius arnouxi

description and notes: lithograph; printed by Maclure \& Macdonald; figures shown $1 / 6$ natural size; two-page plate

article: Flower, William Henry. "On the recent ziphioid whales, with a description of the skeleton of Berardius arnouxi." 8:203-234.

Plate 29

subject: Berardius arnouxi; Hyperoodon rostratus description and notes: lithograph; printed by Maclure \& Macdonald

article: Flower, William Henry. "On the recent ziphioid whales, with a description of the skeleton of Berardius arnouxi." 8:203-234.

Volume $9(1877)$

Plate 6: "Dentition"

subject: Elephas melitensis; Elephas mnaidriensis

description and notes: lithograph; printed by Maclure \& Macdonald; plate signed W.H. Wesley, ad. nat lith.

article: Adams, A. Leith. "On the dentition and osteology of the Maltese fossil elephants, being a description of remains discovered by the author in Malta between the years 1860 and 1866 ." $9: 1-124$. 
Plate 7: "Dentition"

subject: Elephas mnaidriensis

description and notes: lithograph; printed by

Maclure \& Macdonald; plate signed V.H. Wesley, ad. nat lith.; figures shown natural size

article: Adams, A. Leith. "On the dentition and osteology of the Maltese fossil elephants, being a description of remains discovered by the author in Malta between the years 1860 and 1866." 9:1-124.

Plate 10: "Vertebrae Ribs Radius Ulna Astragalus" subject: Elephas mnaidriensis; Elephas melitensis

description and notes: lithograph; printed by Maclure \& Macdonald; plate signed W.H. Wesley, ad. nat lith.

article: Adams, A. Leith. "On the dentition and osteology of the Maltese fossil elephants, being a description of remains discovered by the author in Malta between the years 1860 and 1866." 9:1-124.

Plate 16: "Astragalus Calcaneum"

subject: Elephas mnaidriensis; Elephas melitensis

description and notes: lithograph; printed by Maclure \& Macdonald; plate signed W.H. Wesley, ad. nat lith.; figures shown natural size article: Adams, A. Leith. "On the dentition and osteology of the Maltese fossil elephants, being a description of remains discovered by the author in Malta between the years 1860 and 1866." 9:1-124.

Plate 17: "Carpus Tarsus"

subject: Elephas mnaidriensis; Elephas melitensis

description and notes: lithograph; printed by Maclure \& Macdonald; plate signed W.H. Wesley, ad. nat Lith.; figures shown natural size

article: Adams, A. Leith. "On the dentition and osteology of the Maltese fossil elephants, being a description of remains discovered by the author in Malta between the years 1860 and 1866." 9:1-124. 
Plate 18: "Carpus"

subject: Elephas mnaidriensis; Elephas melitensis

description and notes: lithograph; printed by Maclure \& Macdonald; plate signed W.H. Wesley, ad. nat lith.; figures shown natural size

article: Adams, A. Leith. "On the dentition and

osteology of the Maltese fossil elephants, being a description of remains discovered by the author in Malta between the years 1860 and 1866." 9:1-124.

Plate 19: "Tarsus, Metatarsus, Nietacarpus, Phalanx" subject: Elephas mnaidriensis; Elephas melitensis

description and notes: lithograph; printed by Maclure \& Macdonald; plate signed W.H. Wesley, ad. nat Lith.; figures shown natural size article: Adams, A. Leith. "On the dentition and osteology of the Maltese fossil elephants, being a description of remains discovered by the author in Malta between the years 1860 and 1866." $9: 1-124$.

Plate 20: "Metacarpus, Metatarsus, Phalanx, Sesamoid" subject: Elephas mnaidriensis; Elephas melitensis

description and notes: lithograph; printed by Maclure \& Macdonald; plate signed W.H. Wesley, ad. nat Lith.; figures shown natural size article: Adams, A. Leith. "On the dentition and osteology of the Naltese fossil elephants, being a description of remains discovered by the author in Malta between the years 1860 and 1866." $9: 1-124$.

Volume 10 (1879)

Plate 55: "Axial Skeleton of the Pelecanidae" subject: Pelecanus

description and notes: lithograph; printed by

Hanhart; plate signed W.H. Wesley ad nat. del. article: Mivart, St. George. "On the axial skeleton of the Pelecanidae." 10:315-378.

Plate 56: "Axial Skeleton of the Pelecanidae" subject: Sula

description and notes: lithograph; printed by

Hanhart; plate signed W.H. Wesley ad nat. del. article: Mivart, St. George. "On the axial skeleton of the Pelecanidae." 10:315-378. 
Plate 57: "Axial Skeleton of the Pelecanidae" subject: Phalacrocorax

description and notes: 1ithograph; printed by Hanhart; plate signed W.H. Wesley ad nat. del. article: Mivart, St. George. "Cn the axial skeleton of the Pelecanidae."! 10:315-378.

Plate 58: "Axial Skeleton of the Pelecanidae" subject: Plotus

description and notes: lithograph; printed by Hanhart; plate signed W.H. Wesley ad nat. del. article: Mivart, St. George. "On the axial skeleton of the Pelecanidae." 10:315-378.

Plate 59: "Axial Skeleton of the Pelecanidae" subject: Pelecanus; Sula description and notes: Iithograph; printed by Hanhart; plate signed W.H. Wesley ad nat. del. article: Mivart, St. George. "On the axial skeleton of the Pelecanidae." 18:315-378.

Plate 60: "Axial Skeleton of the Pelecanidae" subject: Sula; Phalacrocorax

description and notes: lithograph; printed by Hanhart; plate signed W.H. Wesley ad nat. del. article: Mivart, St. George. "On the axial skeleton of the Pelecanidae." 10:315-378.

Plate 61: "Axial Skeleton of the Pelecanidae" subject: Phalacrocorax; Plotus

description and notes: lithograph; printed by Hanhart; plate signed W.H. Wesley ad nat. del. article: Nivart, St. George. "On the axial skeleton of the Pelecanidae." 10:315-378.

Plate 74: "Fins of Elasmobranchs"

subject: Zygaena malleus; Lamna cornubica; Mustelus antarcticus

description and notes: 1ithograph; printed by Hanhart

article: Mivart, St. George. "Notes on the fins of Elasmobranchs, with considerations on the nature and homologues of vertebrate limbs." 10:439-484.

Plate 75: "Fins of Elasmobranchs"

subject: Lamna cornubica; Notidanus cinereus;

Scyllium canicula; Ginglymostoma cirratum

description and notes: lithograph; printed by Hanhart

article: Mivart, St. George. "Notes on the fins of Elasmobranchs, with considerations on the nature and homologues of vertebrate limbs." 10:439-484. 
Plate 76: "Fins of Elasmobranchs"

subject: Ginglymostoma cirratum; Chiloscyllium ocellatum; Cestracion philippi

description and notes: lithograph; printed by Hanhart

article: Mivart, St. George. "Notes on the fins of Elasmobranchs, with considerations on the nature and homologues of vertebrate limbs." 10:439-484.

Plate 77: "Fins of Elasmobranchs"

subject: Acanthias blainvillii; Spinax niger;

Squatina angelus; Pristiophorus japonicus

description and notes: lithograph; printed by Hanhart

article: Mivart, St. George. "rotes on the fins of Elasmobranchs, with considerations on the nature and homologues of vertebrate limbs." 10:439-484.

Plate 78: "Fins of Elasmobranchs"

subject: Pristiophorus japonicus; Pristis

cuspidata; Rhynchobatus djeddensis;

Trygonorhina fasciata; Raia maculata;

Polyodon folium

description and notes: lithograph; printed by Hanhart

article: Mivart, St. George. "Notes on the fins of Elasmobranchs, with considerations on the nature and homologues of vertebrate limbs." 10:439-484.

Plate 79: "Fins of Elasmobranchs"

subject: Callorhynchus antiarcticus; Polypterus bichir

description and notes: lithograph; printed by Hanhart

article: Mivart, St. George. "Notes on the fins of Elasmobranchs, with considerations on the nature and homologues of vertebrate limbs." 10:439-484. 
WEST, George

Volume 6 (1869)

Plate 64

subject: Pristipoma macracanthum; Umbrina elongata; Conodon pacifici

description and notes: lithograph; printed by W. West

article: Günther, Albert. "An account of the fishes of the states of Central America, based on collections made by Capt. J.M. Dow, F. Godman, Esq., and 0. Salvin, Esq." 6:377-494.

Plate 68

subject: Thalassophryne maculosa; Thalassophryne reticulata

description and notes: lithograph; printed by $W$. West

article: Günther, Albert. "An account of the fishes of the states of Central America, based on collections made by Capt. J.M. Low, F. Godman, Esq., and 0. Salvin, Esq." 6:377-494.

Plate 71

subject: Heros citrinellus; Heros margaritifer description and notes: lithograph; printed by $W$. West

article: Günther, Albert. "An account of the fishes of the states of Central America, based on collections made by Capt. J.M. Dow, F. Godman, Esq., and 0. Salvin, Esq." 6:377-494. 
Plate 40: "Foraminifera: Abrohlos Bank" subject: Cornuspira involvens Reuss;

Planispirina exigua Brady; Articulina conico-articulata Batsch; Atriculina multilocularis; Articulina sulcata Reuss; Ophthalmidium inconstans Brady; Spiroloculina planulata Lamarck; Planispirina sigmoidea Brady; Biloculina depressa d'Orbigny; Biloculina ringens Lamarck; Biloculina elongata d'Orbigny; Miliolina seminulum Linne; Biloculina irregularis d'Orbigny; Miliolina bicornis Walker \& Jacob (?); Miliolina oblonga Montagu; Spiroloculina asperula Karrer; Miliolina pygmaea Reuss; Miliolina tricarinata d'Orbigny; Miliolina excisa; Miliolina agglutinans d'orbigny description and notes: lithograph; printed by West, Newman \& Co.; plate signed Geo. West del. ad nat. et lith.

article: Brady, Henry B., W. Kitchen Parker and T. Rupert Jones. "On some Foraminifera from the Abrohlos Bank." 12:211-239.

Plate 41: "Foraminifera: Abrohlos Bank" subject: Hyperammina ramosa Brady; Reophax pilulifera Brady; Haplophragmium canariense d'Orbigny; Reophax scorpiurus Montfort; Haplophragmium latidorsatum Bornemann; Textularia agglutinans d'Orbigny; Reophax fusiformis Williamson; Gypsina inhaerens Schultze; Haplophragmium nanum Brady; Valvulina conica Parker \& Jones description and notes: lithograph; printed by West, Newman \& Co.; plate signed Geo. West del. ad nat. et lith.

article: Brady, Henry B., W. Kitchen Parker and $T$. Rupert Jones. "On some Foraminifera from the Abrohlos Bank." 12:211-239. 
Plate 42: "Foraminifera: Abrohlos Bank" subject: Textularia sagittula Defrance;

Textularia agglutinans d'Orbigny; Textularia abbreviata d'Orbigny; Gaudryina filiformis Berthelin; Gaudryina pupoides d'Orbigny; Gaudryina pupoides var. chilostoma Reuss; Clavulina parisiensis d'Orbigny; Clavulina communis d'Orbigny; Placopsilina cenomana d'Orbigny; Verneuilina spinulosa Reuss; Valvulina conica Parker \& Jones; Peneroplis pertusus Forskal; Truncatulina lobatula Walker \& Jacob; Webbina clavata Jones \& Parker; Ammodiscus gordialis Jones \& Parker description and notes: lithograph; printed by West, Newman \& Co.; plate signed Geo. West del. ad nat. et lith.

article: Brady, Henry B. and W. Kitchen Parker. "On some Foraminifera from the Abrohlos Bank." $12: 211-239$.

Plate 43: "Foraminifera: Abrohlos Bank"

subject: Bolivina textilarioides Reuss; Bolivina aenariensis Costa; Bolivina dilatata Reuss; Bulimina marginata d'Orbigny; Bulimina aculeata d'Orbigny; Bulimina inflata Seguenza; Cassidulina laevigata d'Orbigny; Cassidulina subglobosa Brady; Amphistegina lessonii d'Orbigny; Nonionina exponens; Polystomella striatopunctata Fichtel \& Moll; Polystomella; Nonionina umbilicatula Montagu; Nonionina scapha Fichtel \& Moll; Pullenia sphaeroides d'Orbigny; Pullenia quinqueloba Reuss; Nonionina depressula Walker \& Jacob

description and notes: lithograph; printed by West, Newman \& Co.; plate signed Geo. West ad nat. del. et lith.

article: Brady, Henry B. and W. Kitchen Parker. "On some Foraminifera from the Abrohlos Bank." $12: 211-239$. 
Plate 44: "Foraminifera: Abrohlos Bank"

subject: Nodosaria calomorpha Keuss; Nodosaria pyrula d'Orbigny; Nodosaria hispida d'Orbigny; Nodosaria scalaris Batsch; Nodosaria (D.) obliqua Linné; Cristellaria crepidula Fichtel \& Moll; Nodosaria (D.) mucronata Neugeboren; Polymorphina lactea Walker \& Jacob; Cristellaria variabilis Reuss; Cristellaria cultrata Montfort; Cristellaria calcar Linné; Cristellaria rotulata Lamarck; Cristellaria cassis Fichtel \& Moll;

Cristellaria; Lagena sulcata Walker \& Jacob; Nodosaria scalaris Batsch; Lagena orbignyana Seguenza; Lagena melo d'Orbigny; Lagena lagenoides Williamson; Lagena melo d'Orbigny; Lagena sulcata Walker \& Jacob; Lagena marginata Walker \& Boys; Lagena striata d'Orbigny; Lagena lineata Wiliamson

description and notes: lithograph; printed by West, Newman \& Co.; plate signed Geo. West del. ad nat. et lith.

article: Brady, Henry $b$. and W. Kitchen Parker. "On some Foraminifera from the Abrohlos Bank." $12: 211-239$.

Plate 45: "Foraminifera: Abrohlos Bank" subject: Uvigerina pygmaea d'Orbigny; Rhabdogonium tricarinatum d'Orbigny; Uvigerina asperula Czjzek; Sagrina dimorpha Parker \& Jones; Orbulina universa d'Orbigny; Sphaeroidina bulloides d'Orbigny; Globigerina rubra d'Orbigny; Globigerina conglobata Brady; Globigerina bulloides d'Orbigny; Truncatulina; Truncatulina variabilis d'Orbigny; Planorbulina mediterranensis d'Orbigny; Anomalina ammonoides Reuss; Anomalina ariminensis d'Orbigny; Truncatulina reticulata Czjezek; Truncatulina mundula; Truncatulina lobatula Walker \& Jacob description and notes: lithograph; printed by West, Newman \& Co.; plate signed Geo. West del. ad nat. et lith.

article: Brady, Henry B. and W. Kitchen Parker. "On some Foraminifera from the Abrohlos Bank." $12: 211-239$. 
Plate 46: "Foraminifera: Abrohlos Bank"

subject: Discorbina orbicularis Terquem; Pulvinulina elegans d'Orbigny; Pulvinulina menardii d'Orbigny; Pulvinulina schreibersii d'Orbigny; Pulvinulina oblonga Williamson; Discorbina globularis d'Orbigny; Discorbina bertheloti d'Orbigny; Pulvinulina micheliniana d'Orbigny; Planorbulina acervalis Brady; Cymbalopora poeyi d'Orbigny; Gypsina globulus keuss

description and notes: lithograph; printed by West, Newman \& Co.; plate signed Geo. West del. ad nat. et lith.

article: Brady, Henry B. and W. Kitchen Parker. "On some Foraminifera from the Abrohlos Bank." $12: 211-239$. 
Volume 1 (1835)

Plate 13

subject: Aploa picta; Chlaenius sykesii; Oiceoptoma tetraspilotum; Languria cyanea; Opilus auripennis; Phaenomeris magnifica; Lucanus downesii

description and notes: hand-colored engraving; plate signed J.0. Westwood, F.L.S. del., Swaine sc.

article: Hope, F.W. "Characters and descriptions of several new genera and species of Coleopterous insects." $1: 91-112$.

Plate 14

subject: Coptorhina africana; Lucanus aeratus;

Pholidotus irroratus; Anthicus cyaneus;

Lyprops chrysophthalmus; Isacantha

rhinotioides; Prionus cumingii

description and notes: hand-colored engraving;

plate signed J.O. Westwood, F.L.S. del., Swaine sc.

article: Hope, F.W. "Characters and descriptions of several new genera and species of Coleopterous insects." 1: $91-112$.

Plate 15

subject: Lamia roylii; Lamia crux nigra;

Prionus pertii; Uracanthus triangularis;

Scolecobrotus westwoodii

description and notes: hand-colored engraving; plate signed J.O. Westwood, F.L.S. del., Swaine sc.

article: Hope, F.W. "Characters and descriptions of several new genera and species of Coleopterous insects." 1: $91-112$. 
Plate 16

subject: Prionus hayesii

description and notes: hand-colored engraving; plate signed J.O. Westwood, F.L.S. del., Swaine sc.; folded plate

article: Hope, F.W. "Characters and descriptions of several new genera and species of Coleopterous insects." 1:91-112.

Plate 36: Nycteribia

subject: Nycteribia sykesii [female]; Nycteribia hopei [male]; Nycteribia jenynsii Lmale]; Nycteribia roylii [male]; Nycteribia biarticulata [male and female]; Nycteribia blainvillii [male]; Nycteribia latreillii [male and female]; Nycteribia dufourii

description and notes: engraving; plate signed J.O. Westwood del., Swaine sc.

article: Westwood, J.0. "On Nycteribia, a genus of wingless insects." 1:275-294.

Plate 43

subject: Cancer longipes [male]

description and notes: hand-colored lithograph; printed by C. Hullmandel; plate signed J.O. Westwood, M. Gauci lithog.

article: Bell, Thomas. "Observations on the genus Cancer of Dr. Leach (Platycarcinus, Latr.,), with descriptions of three new species." $1: 335-342$.

Plate 44

subject: Cancer edwardsii

description and notes: hand-colored lithograph; printed by C. Hullmandel; plate signed J.O. Westwood delt., M. Gauci lithog.

article: Bell, Thomas. "Observations on the genus

Cancer of Dr. Leach (Platycarcinus, Latr.,), with descriptions of three new species." $1: 335-342$.

Plate 45

subject: Cancer dentalus

description and notes: hand-colored 1ithograph; printed by C. Hullmandel; plate signed J.O.

Westwood del., M. Gauci lithog.

article: Bell, Thomas. "Observations on the genus

Cancer of Dr. Leach (Platycarcinus, Latr.,), with descriptions of three new species." $1: 335-342$. 
Plate 46

subject: Cancer irroratus

description and notes: hand-colored lithograph;

printed by C. Hullmandel; plate signed J.O.

Westwood delt., W. Gauci lithog.

article: Bell, Thomas. "Observations on the genus

Cancer of Dr. Leach (Platycarcinus, Latr.,),

with descriptions of three new species."

$1: 335-342$.

Volume 2 (1841)

Plate 8

subject: Microrhynchus gibbosus [male];

Microrhynchus depressus [female]; Libinia rostrata [male]

description and notes: hand-colored engraving;

plate signed J.O. Westwood del., Swaine Sc.

article: Bell, Thomas. "Some account of the

Crustacea of the coasts of South America, with

descriptions of new genera and species: founded principally on the collections obtained by Mr.

Cuming and Mr. Miller." 2:39-66.

Plate 9

subject: Rhodia pyriformis [male]; Pelia pulchella [male]; Herbstia edwardsii [male]; Thoe erosa [male]; Hyas edwardsii [male]; Pisa spinipes [male]; Pisa aculeata [female] description and notes: hand-colored engraving; plate signed J.O. Westwood del., Swaine Sc. article: Bell, Thomas. "Some account of the Crustacea of the coasts of South America, with descriptions of new genera and species: founded principally on the collections obtained by Mr. Cuming and Mr. Miller." 2:39-66.

Plate 10

subject: Mithrax rostratus [male]; Mithrax ursus [female]

description and notes: hand-colored lithograph; printed by C. Hullmandel; plate signed J.O.

Westwood del., M. Gaua lithog.

article: Bell, Thomas. "Some account of the Crustacea of the coasts of South America, with descriptions of new genera and species: founded principally on the collections obtained by Mr. Cuming and Mr. Miller." 2:39-66. 
Plate 11

subject: Mithrax nodosus [male]; Mithrax denticulatus [female]; Mithrax pygmaeus [male]; Epialtus marginatus [female]

description and notes: hand-colored engraving; plate signed J.O. Westwood del., Swaine Sc.

article: Bell, Thomas. "Some account of the

Crustacea of the coasts of South America, with descriptions of new genera and species: founded principally on the collections obtained by $M r$. Cuming and Mr. Miller." 2:39-66.

Plate 12

subject: Othonia sex-dentata [female]; Othonia quinque-dentata [female]; Tyche lamellifrons [male]; Pericera villosa [male]; Pericera ovata [female]; Pericera heptacantha [male] description and notes: hand-colored engraving; plate signed J.O. Westwood del., Swaine Sc. article: Bell, Thomas. "Some account of the Crustacea of the coasts of South America, with descriptions of new genera and species: founded principally on the collections obtained by Mr. Cuming and Mr. Miller." 2:39-66.

Plate 13

subject: Epialtus marginatus [male]

description and notes: hand-colored lithograph; printed by C. Hullmandel; plate signed J.O. Westwood del., M. Gaua lithog.

article: Bell, Thomas. "Some account of the Crustacea of the coasts of South America, with descriptions of new genera and species: founded principally on the collections obtained by Mr. Cuming and Mr. Miller." 2:39-66.

Plate 14

subject: Athalia centifoliae

description and notes: hand-colored engraving; plate signed J.O. Westwood delt., J. Swaine sct.; plate shows insect in all stages of its life cycle

article: Yarrell, William. "Some observations on the economy of an insect destructive to turnips." 2:67-70.

Plate 29

subject: Sceliages iopas; Anomiopsis dioscorides; Anomiopsis sterquilinus

description and notes: engraving; plate signed J.O.W. delt., Swaine sc.

article: Westwood, J.O. "Descriptions of several new species of insects belonging to the family of the sacred beetles." 2:155-163. 


\section{Volume 3 (1849)}

\section{Plate 14}

subject: Chiroscelis digitata, Westw.;

Chiroscelis bifenestrella, Westw.;

Chiroscelis passaloides, Westw.; Prioscelis

fabricii, Hope.; Prioscelis (Iphius) serrata, Hope.; Prioscelis (Iphius) raddoni, Westw.; Prioscelis (Iphius) crassicornis, Westw.

description and notes: lithograph; printed by Day \& Haghe; signed with overlapping "JOW" monogram

article: Westwood, J.U. "Descriptions of some coleopterous insects from tropical Africa, belonging to the section Heteromera." 3:207-230.

Plate 15

subject: Calostega purpuripennis, Westw.;

Pycnocerus westermanni, Hope.; Odontopus

cupreus, Fabr.; Nyctobates moerens, Westw.;

Nyctobates rotundicollis, Westw.; Nyctobates confusus, Westw.; Nyctobates confuscus var.

angustior; Nyctobates transversalis, Westw.;

Nyctobates hypocrita, Dej.; Nyctobates

punctatus, Fabr.; Nyctobates brevicornis,

Westw.; Megacantha tenebrosa, Westw.;

Nesioticus flavo-pictus, Westw.; Ogcoosoma granularis, Westw.

description and notes: lithograph; printed by Day \& Haghe

article: Westwood, J.O. "Descriptions of some coleopterous insects from tropical Africa, belonging to the section Heteromera." 3:207-230.

\section{Volume 10 (1879)}

Plate 85: "Synopsis of the Uraniidae" subject: Coronidia orithea [larva and pupa];

Coronidia aeola; Coronidia boreada; Manidia lunus; Uranidia sloanus; Chrysiridia

rhipheus; Alcidia orontes; Lyssidia patroclus

description and notes: 1ithograph; printed by Hanhart; plate signed J.O.W. del., R.H.F. Rippon lith.

article: Westwood, J.O. "Observations on the Uraniidae, a family of lepidopterous insects, with a synopsis of the family and a monograph of Coronidia, one of the genera of which it is composed." 10:507-542. 
Plate 86: "Synopsis of the Uraniidae"

subject: Erebus (Patula) macrops [male and female]; Urapteryx sambucaria; Hydria undulata; Strophidia vollenhovii; Asthenidia podaliriaria; Attacus pavonia minor; Endromis versicolor; Eudaemonia semiramis; Aglaia tau; Actias luna; Gastropacha quercifolia; Epicopeia polydora

description and notes: lithograph; printed by Hanhart; plate signed J.O.W. del., R.H.F. Rippon lith.

article: Westwood, J.O. "Observations on the Uraniidae, a family of lepidopterous insects, with a synopsis of the family and a monograph of Coronidia, one of the genera of which it is composed." 10:507-542.

Plate 87: "Synopsis of the Uraniidae"

subject: Alcidia boops [male]; Alcidia metaurus; Coronidia orithea var.; Coronidia erecthea; Coronidia boreada; Coronidia paulina; Coronidia egina; Coronidia rosina description and notes: hand-colored lithograph; printed by Hanhart; plate signed J.O.W. del., R.H.F. Kippon lith.

article: Westwood, J.O. "Observations on the Uraniidae, a family of lepidopterous insects, with a synopsis of the family and a monograph of Coronidia, one of the genera of which it is composed." 10:507-542.

Plate 88: "Synopsis of the Uraniidae" subject: Coronidia aeola; Coronidia nicaraguana; Coronidia columbiana; Coronidia granadina; Coronidia japet; Coronidia biblina; Coronidia interlineata; Coronidia briseis; Coronidia genevana; Coronidia leachii

description and notes: hand-colored lithograph; printed by Hanhart; plate signed J.O.W. del., R.H.F. Rippon lith.

article: Westwood, J.0. "Observations on the Uraniidae, a family of lepidopterous insects, with a synopsis of the family and a monograph of Coronidia, one of the genera of which it is composed." 10:507-542. 
WILLIAMS, Edwin M. [f1.1840/1860s]

\section{Volume 5 (1866)}

Plate 28

subject: Doris ellioti; Doris pardalis; Doris concinna; Doris fragilis; Doris castanea; Doris osseosa; Goniodoris modesta

description and notes: hand-colored lithograph; printed by $M$. \& N. Hanhart

article: Alder, Joshua and Albany Hancock. "Notice of a collection of nudibranchiate Mollusca made in India by Walter Elliot, Esq., with

descriptions of several new genera and species." $5: 113-147$.

Plate 29

subject: Doris formosa; Doris striata; Doris carinata; Chromodoris zebrina; Doridopsis tuberculosa; Trevelyana bicolor

description and notes: hand-colored lithograph; printed by $M$. \& $N$. Hanhart

article: Alder, Joshua and Albany Hancock. "Notice of a collection of nudibranchiate Nollusca made in India by Walter Elliot, Esq., with descriptions of several new genera and species." $5: 113-147$.

Plate 30

subject: Doris areolata; Doris rusticata; Doris tristis; Doris apiculata; Doris funebris

description and notes: hand-colored lithograph; printed by $M$. \& $N$. Hanhart

article: Alder, Joshua and Albany Hancock. "Notice of a collection of nudibranchiate Mollusca made in India by Walter Elliot, Esq., with

descriptions of several new genera and species." 5: $113-147$. 
Plate 31

subject: Doridopsis rubra; Doridopsis fusca; Doridopsis gemmacea; Doridopsis pustulosa; Doridopsis clavulata; Doridopsis nigra;

Doridopsis nigra var. b; Doridopsis nigra var. a; Doridopsis punctata; Doridopsis miniata; Doridopsis atromaculata

description and notes: hand-colored lithograph; printed by $M . \& N$. Hanhart

article: Alder, Joshua and Albany Hancock. "Notice of a collection of nudibranchiate Mollusca made in India by Walter Elliot, Esq., with descriptions of several new genera and species." 5: 113-147.

Plate 32

subject: Goniodoris citrina; Plocamophorus ceylonicus; Kalinga ornata

description and notes: hand-colored lithograph; printed by $M$. \& $N$. Hanhart

article: Alder, Joshua and Albany Hancock. "Notice of a collection of nudibranchiate Mollusca made in India by Walter Elliot, Esq., with descriptions of several new genera and species." 5:113-147.

Plate 33

subject: Doris villosa; Goniodoris aspersa;

Scyllaea marmorata; Scyllaea viridis;

Melibe fimbriata; Melibaea viridis Kel.?;

Bornella digitata; Madrella ferruginosa;

Glaucus forsteri; Eolis unilineata; Eolis militaris; Eolis ocellata; Phyllobranchus orientalis

description and notes: hand-colored lithograph; printed by $M$. \& $N$. Hanhart

article: Alder, Joshua and Albany Hancock. "Notice of a collection of nudibranchiate Mollusca made in India by Walter Elliot, Esq., with descriptions of several new genera and species." 5:113-147. 
WILLIS, G. [f $1.1870-1900]$

Volume 6 (1869)

Plate 3

subject: Delphinus gadamu

description and notes: lithograph; printed by M. \&

$\mathrm{N}$. Hanhart; plate signed Willis del. et lith.

article: Owen, [Professor]. "On some Indian Cetacea collected by Walter Elliot, Esq." 6:17-47.

Plate 5

subject: Delphinus fusiformis; Delphinus lentiginosus

description and notes: lithograph; printed by $M$. \& $\mathrm{N}$. Hanhart; plate signed Willis del. et lith. article: Owen, [Professor]. "On some Indian Cetacea collected by Walter Elliot, Esq." 6:17-47.

Plate 6

subject: Delphinus maculiventer; Delphinus pomeegra

description and notes: lithograph; printed by M. \&

N. Hanhart; plate signed Willis del. et lith.

article: Owen, [Professor]. "On some Indian Cetacea collected by Walter Elliot, Esq." 6:17-47.

Plate 9

subject: Phocoena brevirostris

description and notes: lithograph; printed by $M$. \& N. Hanhart; plate signed Willis del. et lith.; shows details of skull

article: Owen, [Professor]. "On some Indian Cetacea collected by Walter Elliot, Esq." 6:17-47.

Plate 10

subject: Physeter simus

description and notes: lithograph; printed by $M$. \& N. Hanhart; plate signed Willis del. et lith.; described in text as "Euphysetes simus"

article: Owen, [Professor]. "On some Indian Cetacea collected by Walter Elliot, Esq." 6:17-47. 
Plate 11

subject: Physeter simus

description and notes: 1ithograph; printed by $M$. \& N. Hanhart; plate signed Willis del. et lith.; described in text as "Euphysetes simus"; shows side view of animal and skeleton

article: Owen, [Professor]. "On some Indian Cetacea collected by Walter Elliot, Esq." 6:17-47.

Plate 12

subject: Physeter simus

description and notes: 1ithograph; printed by $M$. \& N. Hanhart; plate signed Willis del. et lith.; described in text as "Euphysetes simus"; shows views of skull

article: Owen, [Professor]. "On some Indian Cetacea collected by Walter Elliot, Esq." 6:17-47.

Plate 13

subject: Physeter simus

description and notes: lithograph; printed by $M$. \& N. Hanhart; plate signed Willis del. et lith.; described in text as "Euphysetes simus"; shows views of skull

article: Owen, [Professor]. "On some Indian Cetacea collected by Walter Elliot, Esq." 6:17-47. 
WILSON, Edwin (1856-1915)

\section{Volume 11 (1885)}

\section{Plate 84: "Odontolabini"}

subject: Neolucanus laticollis [male and female]; Neolucanus lansbergii [female]; Heterochthes brachypterus [male and female]; Heterochthes andamanensis [male and female]; Neolucanus castanopterus [male and female]; Neolucanus swinhoii [male and female]

description and notes: lithograph; printed by Mintern Bros.; plate signed Edwin Wilson del. et lith.

article: Leuthner, Franz. "A monograph of the Odontolabini, a subdivision of the coleopterous family Lucanidae." 11:385-491.

Plate 85: "Odontolabini"

subject: Neolucanus marginatus [male and female]; Neolucanus pallescens [male]; Neolucanus parryi [female]; Neolucanus sinicus [male and female]; Neolucanus championi [male and female]; Neolucanus saundersi [male and female]; Neolucanus cingulatus [female]; Neolucanus lama [male and female]; Neolucanus lama var. angulatus Hope description and notes: lithograph; printed by Mintern Bros.; plate signed Edwin Wilson del. et lith.

article: Leuthner, Franz. "A monograph of the Odontolabini, a subdivision of the coleopterous family Lucanidae." 11:385-491.

Plate 86: "Odontolabini"

subject: Odontolabis siva [male and female] description and notes: lithograph; printed by Mintern Bros.; plate signed Edwin Wilson del. et lith.

article: Leuthner, Franz. "A monograph of the Odontolabini, a subdivision of the coleopterous family Lucanidae." 11:385-491. 
Plate 87: "Odontolabini"

subject: Odontolabis gracilis [male and female];

Odontolabis dalmani [male and female]

description and notes: lithograph; printed by

Mintern Bros.; plate signed Edwin Wilson del. et lith.

article: Leuthner, Franz. "A monograph of the Odontolabini, a subdivision of the coleopterous family Lucanidae." 11:385-491.

Plate 88: "Odontolabini"

subject: Odontolabis bellicosus [male and female]; Odontolabis celebensis [male];

Odontolabis platynotus [male and female]

description and notes: lithograph; printed by

Mintern Bros.; plate signed Edwin Wilson del. et lith.

article: Leuthner, Franz. "A monograph of the Odontolabini, a subdivision of the coleopterous family Lucanidae." $11: 385-491$.

Plate 89: "Odontolabini"

subject: Odontolabis alces [male and female]

description and notes: lithograph; printed by

Mintern Bros.; plate signed Edwin Wilson del. et lith.

article: Leuthner, Franz. "A monograph of the Odontolabini, a subdivision of the coleopterous family Lucanidae." 11:385-491.

Plate 90: "Odontolabini"

subject: Odontolabis stevensi [male and female]; Odontolabis duivenbodii [male and female]

description and notes: lithograph; printed by

Mintern Bros.; plate signed Edwin Wilson del. et lith.

article: Leuthner, Franz. "A monograph of the Odontolabini, a subdivision of the coleopterous family Lucanidae." 11:385-491.

Plate 91: "Odontolabini"

subject: Odontolabis sinensis [male and female]; Odontolabis mouhoti [male]; Odontolabis gazella [male]; Odontolabis cuvera [male and female ]

description and notes: lithograph; printed by Mintern Bros.; plate signed Edwin Wilson del. et lith.

article: Leuthner, Franz. "A monograph of the Odontolabini, a subdivision of the coleopterous family Lucanidae." 11:385-491. 
Plate 92: "Odontolabini"

subject: Odontolabis delesserti Lmale and female]; Odontolabis burmeisteri [male]

description and notes: lithograph; printed by

Mintern Bros.; plate signed Edwin Wilson del. et lith.

article: Leuthner, Franz. "A monograph of the Odontolabini, a subdivision of the coleopterous family Lucanidae." 11:385-491.

Plate 93: "Odontolabini"

subject: Odontolabis vollenhoveni [male and female]; Odontolabis wollastoni [male and female]; Odontolabis ludekingi [male and female]

description and notes: lithograph; printed by Mintern Bros.; plate signed Edwin Wilson del. et lith.

article: Leuthner, Franz. "A monograph of the Odontolabini, a subdivision of the coleopterous family Lucanidae." 11:385-491.

Plate 94: "Odontolabini"

subject: Odontolabis lacordairii [male and

female]; Odontolabis ludekingi [male]

description and notes: lithograph; printed by

Mintern Bros.; plate signed Edwin Wilson del. et lith.

article: Leuthner, Franz. "A monograph of the Odontolabini, a subdivision of the coleopterous family Lucanidae." 11:385-491.

Plate 95: "Odontolabini"

subject: Odontolabis castelnaudi [male and female]; Odontolabis sommeri [male and female]; Odontolabis lowii [male];

Odontolabis brookeanus [male and female]

description and notes: lithograph; printed by

Mintern Bros.; plate signed Edwin Wilson del. et lith.

article: Leuthner, Franz. "A monograph of the Odontolabini, a subdivision of the coleopterous family Lucanidae." 11:385-491. 


\section{Plate 96: "Odontolabini"}

subject: Odontolabis latipennis [male and female]; Odontolabis fratellus [male and female]; Odontolabis camelus [male]; Odontolabis gazella [male and female]; Odontolabis inaequalis [male]

description and notes: lithograph; printed by Mintern Bros.; plate signed Edwin Wilson del. et lith.

article: Leuthner, Franz. "A monograph of the Odontolabini, a subdivision of the coleopterous family Lucanidae." 11:385-491.

Plate 97: "Odontolabini"

subject: Odontolabis striatus [male and female];

Odontolabis striatus var. cephalotes

[female]; Odontolabis aeratus [male and

female]; Odontolabis carinatus [male and

female]; Odontolabis carinatus var.

cingalens is [female]

description and notes: lithograph; printed by

Mintern Bros.; plate signed Edwin Wilson del. et lith.

article: Leuthner, Franz. "A monograph of the Odontolabini, a subdivision of the coleopterous family Lucanidae." 11:385-491.

\section{Volume 15 (1901)}

Plate 21

subject: Cervus belgrandi

description and notes: lithograph; plate signed E. Wilson del. et lith. Cambridge

article: Harmer, Sidney F. "On a specimen of

Cervus belgrandi Lart. (C. verticornis

Dawk.) from the forest-bed of East Anglia." 15:97-108.

Plate 50: "Anatomy of Polypterus"

subject: Polypterus lapradei [female and male]; Polypterus senegalus [female]

description and notes: hand-colored lithograph; plate signed E. Wilson, Cambridge

article: Budgett, J.S. "On some points in the anatomy of Polypterus." 15:323-338.

Plate 51: "Anatomy of Polypterus" subject: Polypterus senegalus [male]

description and notes: hand-colored lithograph; plate signed E. Wilson, Cambridge article: Budgett, J.S. "On some points in the anatomy of Polypterus." 15:323-338. 
Plate 52: "Anatomy of Polypterus"

subject: Polypterus senegalus [male and female]; Polypterus lapradei

description and notes: hand-colored lithograph;

plate signed E. Wilson, Cambridge

article: Budgett, J.S. "On some points in the anatomy of Polypterus." 15:323-338. 
WITH, Carl Johannes (b. 1877)

Volume 18 (1907-1911)

Plate 29: "South American Cheliferinae"

subject: Chelifer imperator [male and female];

Chelifer rex [male]; Chelifer rufus Balz [male]; Chelifer nobilis [male]; Chelifer canestrinii Balz [male]; Chelifer longichelifer Balz [male and female]; Chelifer segmentidentatus Balz [male and female]; Chelifer satanas [male]; Chelifer insignis [female]

description and notes: chromolithograph; plate signed C.J. With del., Huth sc. et imp. article: With, C.J. "An account of the

South-American Cheliferinae in the collections of the British and Copenhagen Museums." $18: 217-340$.

Plate 30: "South American Cheliferinae" subject: Chelifer rudis Balz [male and female]; Chelifer subgracilis [female]; Chelifer subrobustus Balz [female?]; Chelifer antillarum [female]; Chelifer subrudis Balz [female]; Chelifer bicolor Balz [male and female]; Chelifer albomaculatus Balz [male]; Chelifer crassimanus Balz [female]; Chelifer meinertii [female]; Chelifer subrotundatus Balz [female]; Chelifer plumosus [female]; Chelifer nitidimanus Ell. [female and male]; Chelifer michaelsenii Sim. [male]; Chelifer celerrimus [female]

description and notes: lithograph; plate signed C.J. With del., Huth sc. et imp. article: With, C.J. "An account of the South-American Cheliferinae in the collections of the British and Copenhagen Museums." $18: 217-340$. 
Plate 31: "South American Cheliferinae"

subject: Chelifer celerrimus [female]; Chelifer sp. Young [female]; Chelifer ellingsenii

[female]; Chelifer subovatus [male and

female]; Chelifer intermedius Balz [male];

Chelifer communis Balz [male and female];

Chelifer nitidus Ell. [female]; Chelifer

similis Balz [male]; Chelifer argentinus

Thor. [male and female]; Chelifer

macrochelatus Töm. [male]; Chelifer

nodulimanus Töm. [male]; Chelifer cervus

Balz. [male]; Chelifer depressimanus [female];

Chelifer nidifactor Balz [male]; Chelifer

elongatus Ell. [female and male]

description and notes: lithograph; plate signed

C.J. With del., Huth sc. et imp.

article: With, C.J. "An account of the

South-American Cheliferinae in the collections of the British and Copenhagen Museums."

$18: 217-340$. 
WITTHOOS, Pierre (d. 1693)

Volume 6 (1869)

Plate 62

subject: Didus?; Bernicla ruficollis

description and notes: hand-colored lithograph;

printed by M. \& N. Hanhart; plate signed J. Smit lith.; reproduces part of a watercolor by Pierre Witthoos (d. 1693)

article: Newton, Alfred. "On a picture supposed to represent the didine bird of the island of Bourbon (Réunion)." 6:373-376. 
WOLF, Joseph (1820-1899)

\section{Volume 4 (1862)}

\section{Plate 25}

subject: Notornis mantellii

description and notes: hand-colored lithograph; printed by M. \& N. Hanhart; signed "J. Wolf"

article: Mantell, Gideon Algernon. "Notice of the discovery by $\mathrm{Mr}$. Walter Mantell in the Middle Island of New Zealand, of a living specimen of the Notornis, a bird of the rail family, allied to Brachypteryx, and hitherto unknown to naturalists except in a fossil state." 4:69-74.

\section{Plate 58}

subject: Urubitinga schistacea

description and notes: hand-colored lithograph; printed by $M$. \& N. Hanhart; plate signed J. Wolf, lith.; figure shown $1 / 2$ natural size article: Sclater, Philip Lutley. "On some new or little-known species of Accipitres, in the collection of the Norwich Museum." 4:261-266.

Plate 59

subject: Buteo zonocercus

description and notes: hand-colored lithograph; printer not noted on plate; plate signed J. Wolf, lith.; figure shown $1 / 2$ natural size article: Sclater, Philip Lutley. "On some new or little-known species of Accipitres, in the collection of the Norwich Museum." 4:261-266.

Plate 60

subject: Syonium albitarse

description and notes: hand-colored lithograph; printed by M. \& N. Hanhart; plate signed J. Wolf, lith.; figure shown $1 / 2$ natural size article: Sclater, Philip Lutley. "On some new or little-known species of Accipitres, in the collection of the Norwich Museum." 4:261-266. 
Plate 61

subject: Scops usta

description and notes: hand-colored lithograph; printed by $M$. \& N. Hanhart; plate signed $J$.

Wolf, lith.; figure shown natural size

article: Sclater, Philip Lutley. "On some new or

little-known species of Accipitres, in the

collection of the Norwich Museum." 4:261-266.

Plate 62

subject: Buteo fuliginosus

description and notes: hand-colored lithograph; printed by $M$. \& N. Hanhart; plate signed J. wolf, lith.; figure shown $1 / 2$ natural size article: Sclater, Philip Lutley. "Description of a new species of the genus Buteo from Mexico." 4:267.

Plate 63

subject: Ciccaba nigro-1ineata

description and notes: hand-colored lithograph; printed by $M$. \& N. Hanhart; plate signed J. Wolf, lith.; figure shown $1 / 2$ natural size

article: Sclater, Philip Lutley. "Description of a new species of owl of the genus Ciccaba." 4:268.

Plate 64

subject: Balaeniceps rex

description and notes: hand-colored lithograph; printed by $\mathrm{M}$. \& N. Hanhart; plate signed J. Wolf, del., J. Jury, lith.

article: Sclater, Philip Lutley. "On the osteology of Balaeniceps rex (Gould)." 4:269-351.

\section{Plate 77}

subject: Aquila desmursi

description and notes: hand-colored lithograph; printed by M. \& N. Hanhart; plate signed J. Wolf, del. et lith.

article: Gurney, J.H. "Remarks on Aquila desmursii." $4: 365-366$. 


\section{Volume 5 (1866)}

\section{Plate 14}

subject: Chiromys madagascariensis Cuv. [female] description and notes: lithograph; printed by $M$. \& N. Hanhart; plate signed J. Wolf delt., J. Erxleben lith.; figure shown $1 / 2$ natural size article: Owen, [Professor]. "On the aye-aye

(Chiromys, Cuvier; Chiromys madagascariensis, Desm.; Sciurus madagascariensis, Gmel., Sonnerat; Lemur psilodactylus, Schreber, Shaw)." 5:33-101.

\section{Plate 15}

subject: Chiromys madagascariensis Cuv. [male] description and notes: lithograph; printed by $M$. \& N. Hanhart; plate signed J. Wolf delt., J. Erxleben lith.; figure shown $1 / 2$ natural size article: Owen, [Professor]. "Cn the aye-aye

(Chiromys, Cuvier; Chiromys madagascariensis, Desm.; Sciurus madagascariensis, Gmel., Sonnerat; Lemur psilodactylus, Schreber, Shaw)." 5:33-101.

Plate 16

subject: Chiromys madagascariensis Cuv. [male] description and notes: lithograph; printed by $M$. \& $\mathrm{N}$. Hanhart; plate signed J. Wolf delt., J. Erxleben lith.; figure shown $1 / 2$ natural size article: Cwen, [Professor]. "On the aye-aye

(Chiromys, Cuvier; Chiromys madagascariensis, Desm.; Sciurus madagascariensis, Gmel., Sonnerat; Lemur psilodactylus, Schreber, Shaw)." 5:33-101.

Plate 17

subject: Chiromys madagascariensis Cuv. [male] description and notes: lithograph; printed by M. \& N. Hanhart; plate signed J. Wolf delt., J. Erxleben lith.; figure shown $1 / 2$ natural size article: Owen, [Professor]. "On the aye-aye

(Chiromys, Cuvier; Chiromys madagascariensis, Desm.; Sciurus madagascariensis, Gmel., Sonnerat; Lemur psilodactylus, Schreber, Shaw)." 5:33-101. 
Plate 18

subject: Chiromys madagascariensis Cuv. [male]

description and notes: lithograph; printed by M. \& $\mathrm{N}$. Hanhart; plate signed J. Wolf delt., J. Erxleben lith.; figure shown natural size article: Owen, [Professor]. "On the aye-aye (Chiromys, Cuvier; Chiromys madagascariensis, Desm.; Sciurus madagascariensis, Gmel., Sonnerat; Lemur psilodactylus, Schreber, Shaw)." 5:33-101.

Plate 43

subject: Troglodytes gorilla [adult male]

description and notes: hand-colored lithograph; printed by $M$. \& N. Hanhart

article: Owen, [Professor]. "Contributions to the natural history of the anthropoid apes. No. VIII. On the external characters of the gorilla (Troglodytes gorilla, Sav.)." 5:243-284.

Plate 44

subject: Troglodytes gorilla [female and juvenile] description and notes: hand-colored lithograph;

printed by $M$. \& N. Hanhart; plate signed J. Wolf del. et lith.

article: Owen, [Professor]. "Contributions to the natural history of the anthropoid apes. No. VIII. On the external characters of the gorilla (Troglodytes gorilla, Sav.)." 5:243-284.

Volume 6 (1869)

Plate 1

subject: Potamogale velox

description and notes: hand-colored lithograph; printed by M. \& N. Hanhart; signed "J.W.'

article: Allman, George J. "On the characters and affinities of Potamogale, a genus of insectivorous mammals." 6:1-16.

Plate 29

subject: Macheirhamphus alcinus

description and notes: hand-colored lithograph; printed by $M$. \& N. Hanhart; plate signed J. Wolf del. et lith.

article: Gurney, J.H. "Cn a raptorial bird transmitted by $\mathrm{Mr}$. Andersson from Damara Land." $6: 117-118$. 
Volume 7 (1872)

Plate 29

subject: Cervus maral

description and notes: hand-colored lithograph; printed by M. \& N. Hanhart; from an original water-color by Wolf; plate signed J. Smit lith. article: Sclater, P.L. "On certain species of deer now or lately living in the Society's Menagerie." 7:333-352.

Plate 31

subject: Cervus maral

description and notes: hand-colored lithograph; printed by M. \& N. Hanhart; plate signed J. Wolf delt., J. Smit lith.

article: Sclater, P.L. "On certain species of deer now or lately living in the Society's Menagerie." $7: 333-352$.

Plate 33

subject: Cervus taivanus [male]

description and notes: hand-colored lithograph; printed by $M$. \& N. Hanhart; from an original water-color by Wolf; plate signed J. Smit lith. article: Sclater, P.L. "On certain species of deer now or lately living in the Society's

Menagerie." 7:333-352.

Plate 35

subject: Cervus sika [male and female]

description and notes: hand-colored lithograph;

printed by M. \& N. Hanhart; from an original water-color by Wolf; plate signed J. Smit lith. article: Sclater, P.L. "On certain species of deer now or lately living in the Society's Menagerie." 7:333-352.

Plate 36

subject: Cervus duvaucelli [male and female]

description and notes: hand-colored lithograph; printed by $M$. \& N. Hanhart; from an original water-color by Wolf; plate signed J. Smit lith.

article: Sclater, P.L. "On certain species of deer now or lately living in the Society's Menagerie." $7: 333-352$.

Plate 37

subject: Cervus eldi [male and female]

description and notes: hand-colored lithograph; printed by M. \& N. Hanhart; from an original water-color by Wolf; plate signed J. Smit lith. article: Sclater, P.L. "On certain species of deer now or lately living in the Society's

Menagerie." 7:333-352. 
Plate 39

subject: Cervus swinhoii [male and female]

description and notes: hand-colored lithograph; printed by $M$. \& N. Hanhart

article: Sclater, P.L. "On certain species of deer now or lately living in the Society's

Menagerie." $7: 333-352$.

Volume 9 (1877)

Plate 95

subject: Rhinoceros unicornis

description and notes: chromolithograph?, perhaps retouched; printed by $M$. \& N. hanhart; plate signed J. Wolf del., J. Smit lith.

article: Sclater, P.L. "On the rhinoceroses now or 1ately living in the Society's Menagerie."
9:645-660.

Plate 96

subject: Rhinoceros sondaicus

description and notes: chromolithograph?, perhaps retouched; printed by $M$. \& N. Hanhart; plate signed J. Wolf del., J. Smit lith.

article: Sclater, P.L. "On the rhinoceroses now or lately living in the Society's Menagerie." $9: 645-660$.

Plate 97

subject: Rhinoceros sumatrensis

description and notes: chromolithograph?, perhaps retouched; printed by $M . \& N$. Hanhart; plate signed J. Wolf \& J. Smit del. et lith.

article: Sclater, P.L. "On the rhinoceroses now or lately living in the Society's Menagerie." 9:645-660.

Plate 98

subject: Rhinoceros lasiotis

description and notes: chromolithograph?, perhaps retouched; printed by $M$. \& N. Hanhart; plate signed J. Wolf del., J. Smit lith.

article: Sclater, P.L. "On the rhinoceroses now or lately living in the Society's Menagerie."

$9: 645-660$. 


$$
\text { WOLF, Joseph }
$$

Plate 99

subject: Rhinoceros bicornis

description and notes: chromolithograph?, perhaps retouched; printed by M. \& N. Hanhart; plate signed J. Wolf del., J. Smit lith.

article: Sclater, P.L. "On the rhinoceroses now or lately living in the Society's Menagerie." 9:645-660. 
WOODALL, Rev. E.H.

Volume 3 (1849)

Plate 51

subject: Chaunax pictus

description and notes: hand-colored lithograph; printed by Hullmandel \& Walton; author thanks Rev. E.H. Woodall "for the spirited and accurate drawing from which the illustration was taken" (p. 344)

article: Lowe, R.T. "On a new genus of the family Lophidae (Les pectorales pédiculées, Cuv.)

discovered in Madeira." 3:339-344. 
WOODWARD, A.M.

Volume 14 (1898)

Plate 1

subject: Laricsaurus balsami

description and notes: lithograph; printed by

Mintern Eros.; plate signed A.M. Woodward del. et lith.

article: Boulenger, G.A. "On a nothosaurian reptile from the trias of Lombardy, apparently referable to Lariosaurus." 14:1-10. 
WOODWARD, Ellen C. [fl. 1870/1895]

Volume 13 (1895)

Plate 29: "British Palaeogene Bryozoa"

subject: Notamia wetherelli Busk; Membranipora eocena Busk; Membranipora tenuimuralis; Membranipora virguliformis; Membranipora disjuncta; Membranipora crassomuralis; Membranipora buski; Lunulites transiens

description and notes: lithograph; printed by west, Newman; plate signed E.C. \& G.M. Woodward del. et lith.

article: Gregory J.W. "On the British Palaeogene Bryozoa."13:219-279.

Plate 30: "British Palaeogene Bryozoa"

subject: Lunulites transiens; Biselenaria offa;

Micropora cribiformis; Onychocella

magnoaperta; Cribrilina vinei; Schizoporella magnoaperta; Schizoporella magnoincisa;

Adeonellopsis incisa; Adeonellopsis wetherelli

description and notes: 1ithograph; printed by West, Newman; plate signed E.C. \& G.M. Woodward del. et 1 ith.

article: Gregory, J.W. "On the British Palaeogene Bryozoa." 13:219-279.

Plate 31: "British Palaeogene Bryozoa"

subject: Adeonellopsis wetherelli; Lepralia

lonsdalei; Umbonula calcariformis; Umbonula

bartonense; Teichopora clavata; Meniscopora

bigibbera; Conescharellina clithridiata;

Orbitulipora petiolus Lonsd.; Mucronella angus toaecium

description and notes: 1ithograph; printed by west, Newman; plate signed E.C. \& G.M. Woodward del. et 1ith.

article: Gregory J.W. "On the British Palaeogene Bryozoa." 13:219-27.9. 
Plate 32: "British Palaeogene Bryozoa"

subject: Smittia tubularis; Idmonea

bialternata; Idmonea giebeli Stol., Idmonea

seriatopora Reuss; Idmonea seriatopora;

Idmonea coronopus Defr.; Hornera

farehamensis; Entalophora tergemina;

Heteropora glandiformis; Lichenopora

description and notes: lithograph; printed by West, Newman; plate signed E.C. \& G.M. Woodward del. et lith.

article: Gregory, J.W. "On the British Palaeogene Bryozoa." 13:219-279.

Plate 39

subject: Testudo grandidieri

description and notes: lithograph; printed by West, Newman; plate signed E.C. \& G.M. Woodward del. et lith.

article: Boulenger, G.A. "On remains of an extinct gigantic tortoise from Madagascar (Testudo grandidieri, Vaillant)." 13:305-311.

Plate 40

subject: Testudo grandidieri

description and notes: lithograph; printed by West, Newman; plate signed E.C.\& G.M. Woodward del. et lith.

article: Boulenger, G.A. "On remains of an extinct gigantic tortoise from Madagascar (Testudo grandidieri, Vaillant)." 13:305-311.

Plate 41

subject: Testudo grandidieri

description and notes: lithograph; printed by West, Newman; plate signed E.C.\& G.M. Woodward del. et lith.

article: Boulenger, G.A. "On remains of an extinct gigantic tortoise from Madagascar (Testudo grandidieri, Vaillant)." 13:305-311. 
WOODWARD, Gertrude M. [f1. 1880/1912]

Volume 13 (1895)

Plate 29: "British Palaeogene Bryozoa" see Woodward, E.C., 13: Plate 29

Plate 30: "British Palaeogene Bryozoa" see Woodward, E.C., 13: Plate 30

Plate 31: "British Palaeogene Bryozoa" see Woodward, E.C., 13: Plate 31

Plate 32: "British Palaeogene Bryozoa" see Woodward, E.C., 13: Plate 32

Plate 39

see Woodward, E.C., 13: Plate 39

Plate 40

see Woodward, E.C., 13: Plate 40

Plate 41

see Woodward, E.C., 13: Hlate 41 
YOUNG

Volume 1 (1835)

Plate 19

subject: Alepisaurus ferox

description and notes: hand-colored engraving;

plate signed Young \& Zeitter del., Zeitter sc.; species shown $1 / 6$ natural size

article: Lowe, R.T. "Description of a new genus of Acanthopterygian fishes." 1:123-128. 


\section{ZEITTER, John Christian (1796-1862)}

Volume 1 (1835)

Plate 19

see Young, v. 1 (1835): Plate 19

Plate 42

subject: Lagotis pallipes

description and notes: hand-colored engraving; plate signed Zeitter del. et sc.

article: Bennett, E.T. "Additional remarks on the genus Lagotis, with some account of a second species referrible [sic] to it." $1: 331-334$. 


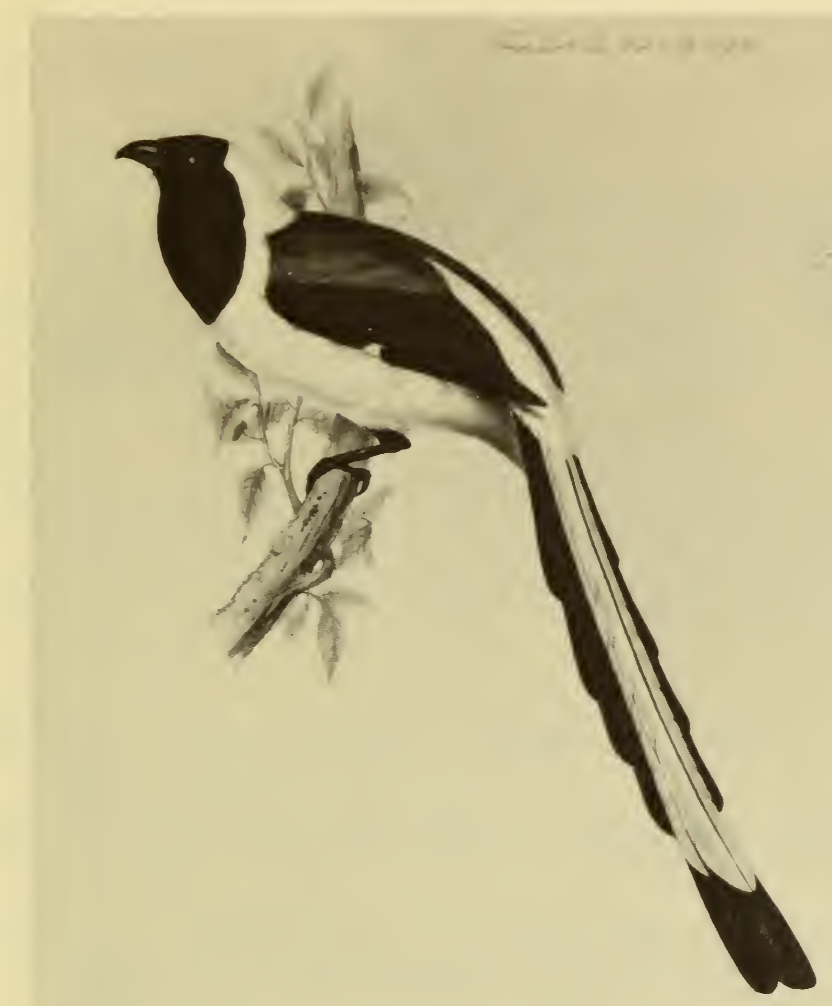

Dendrocilla leucogastra

(Unsigned, 1: Plate 12)

AMNH Library Collections 



\section{UNS IGNED}

\section{Volume 1 (1835)}

\section{Plate 10}

subject: Apteryx australis

description and notes: hand-colored lithograph; printed by $M$. \& N. Hanhart; this plate was apparently cancelled in favor of the Gould version

article: Yarrell, William. "Description, with some additional particulars, of the Apteryx australis of Shaw." 1:71-76.

\section{Plate 12}

subject: Dendrocilla leucogastra

description and notes: hand-colored lithograph; printed by Hullmandel \& Walton; Gordon Sauer states that this illustration is by J. \& E. Gould article: Gould, John. "On a new genus of Corvidae." $1: 87-90$.

Plate 38: Chama

subject: Chama frondosa; Chama pellucida;

Chama lobata; Chama sinuosa; Chama corrugata; Chama spinosa

description and notes: hand-colored engraving; possibly by G.B. Sowerby, II (see Cleeveley, P. 575)

article: Broderip, W.J. "On the genus Chama, Brug., with descriptions of some species apparently not hitherto characterized." $1: 301-306$.

\section{Plate 39: Chama}

subject: Chama pacifica; Chama imbricata; Chama producta; Chama echinata; Chama sordida

description and notes: hand-colored engraving possibly by G.B. Sowerby, II (see Cleeveley, P. 575)

article: Broderip, W.J. "On the genus Chama, Brug., with descriptions of some species apparently not hitherto characterized." $1: 301-306$. 
Plate 59

subject: Alepisaurus ferox

description and notes: engraving; plate signed Swaine sc.

article: Lowe, R.T. "Additional observations on Alepisaurus ferox." $1: 395-400$.

\section{Volume 2 (1841)}

Plate 22

subject: Gerbillus burtoni

description and notes: hand-colored engraving; plate signed Swaine sc.

article: Cuvier, Fred. "Mémoire sur les Gerboises et les Gerbilles." 2:131-148.

Plate 23

subject: Gerbillus burtoni

description and notes: engraving; plate signed Swaine sc.; shows skull, teeth and internal organs

article: Cuvier, Fred. "Mémoire sur les Gerboises et les Gerbilles." 2:131-148.

Plate 24

subject: Dipus hirtipes; Alactaga

description and notes: engraving; plate signed Swaine sc.; shows skulls and teeth

article: Cuvier, Fred. "Mémoire sur les Gerboises et les Gerbilles." 2:131-148.

Plate 25

subject: Gerbillus egyptius; Gerbillus pyramidum; Gerbillus pygargus; Gerbillus indicus

description and notes: engraving; plate signed Swaine sc.; shows skulls and teeth

article: Cuvier, Fred. "Mémoire sur les Gerboises et les Gerbilles." 2:131-148.

Plate 26

subject: Gerbillus sp.?; Gerbillus africanus; Gerbillus brevicaudatus; Gerbillus otarius description and notes: engraving; plate signed Swaine sc.; shows skulls and teeth

article: Cuvier, Fred. "Mémoire sur les Gerboises et les Gerbilles." 2:131-148. 
Plate 35

subject: Galictis vittata

description and notes: hand-colored lithograph

article: Bell, Thomas. "Observations on the genus

Galictis (Bel1), with the description of a new

species." 2:201-206.

Plate 36

subject: Galictis vittata

description and notes: lithograph; gives details of anatomy

article: Bell, Thomas. "Observations on the genus Galictis (Bell), with the description of a new species." 2:201-206.

Plate 37

subject: Galictis allamandi

description and notes: hand-colored lithograph; printed by $\mathrm{C}$. Hullmandel

article: Bell, Thomas. "Observations on the genus

Galictis (Bell), with the description of a new species." 2:201-206.

Plate 39

subject: Aigocerus niger

description and notes: hand-colored etching

article: Harris, W.C. "Description of a new species of antelope." 2:213-215.

Plate 60

subject: Ambassis barlovi; Mastacembelus

armatus; Ophicephalus leucopunctatus

description and notes: hand-colored engraving; plate signed Swaine sc.

article: Sykes, W.H. "On the fishes of the Dukhun." $2: 349-378$.

Plate 61

subject: Gobius kurpah; Cyprinus abramioides;

Varicorhinus bobree; Barbus mussullah

description and notes: hand-colored engraving;

plate signed Swaine sc.

article: Sykes, W.H. "On the fishes of the Dukhun." $2: 349-378$.

Plate 62

subject: Barbus kolus; Chondrostoma kawrus;

Chondrostoma mullya; Chondrostoma wattanah

description and notes: hand-colored engraving;

plate signed Swaine sc.

article: Sykes, W.H. "On the fishes of the Dukhun." $2: 349-378$. 
Plate 63

subject: Chela oweni; Rohtee ogilbii; Rohtee vigorsii; Belone graii

description and notes: hand-colored engraving; plate signed Swaine sc.

article: Sykes, W.H. "On the fishes of the Dukhun." $2: 349-378$.

Plate 64

subject: Cobitis ruppelli; Schilbe boalis; Hypophthalmus goongwaree; Hypophthalmus taakree

description and notes: hand-colored engraving; plate signed Swaine sc.

article: Sykes, W.H. "On the fishes of the Dukhun." $2: 349-378$.

Plate 65

subject: Bagrus yarrelli; Platystoma seenghala; Phractocephalus kuturnee

description and notes: hand-colored engraving;

plate signed Swaine sc.

article: Sykes, W.H. "On the fishes of the Dukhun." $2: 349-378$.

Plate 66

subject: Phractocephalus gogra; Pimelodus

seengtee; Ageneiosus childreni

description and notes: hand-colored engraving;

plate signed Swaine sc.

article: Sykes, W.H. "On the fishes of the Dukhun." $2: 349-378$.

Plate 67

subject: Phractocephalus itchkeea; Mystus

badgee; Anguilla elphinstonei

description and notes: hand-colored engraving;

plate signed Swaine sc.

article: Sykes, W.H. "On the fishes of the Dukhun." $2: 349-378$.

Plate 68

subject: Phascolomys wombat

description and notes: engraving; plate signed

Taylor sculp.; shows articulated skeleton article: Owen, Richard. "On the osteology of the Marsupialia." 2:379-408.

Plate 69

subject: Phascolarctos fuscus

description and notes: engraving; plate signed Taylor sculp.; gives views of skull

article: Owen, Richard. "On the osteology of the Marsupialia." 2:379-408. 
Volume 3 (1849)

Plate 12

subject: Piesarthrius marginellus; Strongylurus scutellatus; Coptopterus cretifer;

Stenochorus rubripes; Stenochorus gigas;

Coptocercus unifasciatus; Stenochorus

uniguttatus; Stenochorus mitchelli;

Stenochorus trimaculatus

description and notes: hand-colored engraving;

plate signed J. Swaine sc.

article: Hope, F.W. "Observations on the

Stenochoridae of New Holland, with descriptions of new genera and species of that family." $3: 187-202$.

Plate 36

subject: Apteryx australis

description and notes: 1ithograph; printed by Day \& Haghe; shows anatomy of female reproductive organs

article: Owen, Richard. "On the anatomy of the Apteryx australis, Shaw. Part II. (Myology.)" 3:277-301.

Volume 13 (1895)

Plate 33

subject: Lophopsittacus mauritianus; Astur alphonsi; Strix sauzieri

description and notes: apparently a photoengraving from an original drawing; printed by Cambridge Engraving Company; unsigned

article: Newton, Edward. "On additional bones of the dodo and other extinct birds of Mauritius obtained by Mr. Théodore Sauzier." 13:281-302.

Plate 34

subject: Plotus nanus; Butorides mauritianus;

Sarcidiornis mauritiana; Anas theodori

description and notes: apparently a photoengraving from an original drawing; printed by Cambridge Engraving Company; unsigned

article: Newton, Edward. "On additional bones of the dodo and other extinct birds of Mauritius obtained by Mr. Théodore Sauzier." 13:281-302. 


\section{Plate 35}

subject: Fulica newtoni; Aphanapteryx broekei

description and notes: apparently a photoengraving from an original drawing; printed by Cambridge Engraving Company; unsigned

article: Newton, Edward. "On additional bones of the dodo and other extinct birds of Mauritius obtained by Mr. Théodore Sauzier." 13:281-302.

Plate 36

subject: Didus ineptus

description and notes: apparently a photoengraving from an original drawing; printed by Cambridge Engraving Company; unsigned

article: Newton, Edward. "On additional bones of the dodo and other extinct birds of Mauritius obtained by Mr. Théodore Sauzier." 13:281-302.

Plate 37

subject: Didus ineptus

description and notes: apparently a photoengraving from an original drawing; printed by Cambridge Engraving Company; unsigned

article: Newton, Edward. "On additional bones of the dodo and other extinct birds of Mauritius obtained by Mr. Théodore Sauzier." 13:281-302.

Plate 42: "Mauritian Land-Tortoises"

subject: Testudo sauzieri; Testudo indica?;

Testudo triserrata; Testudo sumeirei

description and notes: lithograph; printed by Edwin Wilson; unsigned

article: Gadow, Hans. "On the remains of some gigantic land-tortoises, and of an extinct lizard, recently discovered in Mauritius." $13: 313-324$.

Plate 43: "Mauritian Land-Tortoises"

subject: Testudo sumeirei; Testudo inepta;

Testudo triserrata

description and notes: lithograph; printed by Edwin Wilson; unsigned

article: Gadow, Hans. "On the remains of some gigantic land-tortoises, and of an extinct lizard, recently discovered in Mauritius." $13: 313-324$. 
Plate 44

subject: Didosaurus mauritianus; Testudo sumeirei; Testudo atlas

description and notes: lithograph; printed by Edwin Wilson; unsigned

article: Gadow, Hans. "On the remains of some gigantic land-tortoises, and of an extinct lizard, recently discovered in Mauritius." $13: 313-324$.

Volume 14 (1898)

Plate 20: "Oriental Hesperiidae"

subject: Matapa purpurascens [male]; Hasora mus

[male]; Notocrypta quadrata [male]; Ismene

tuckeri [male]; Hasora mus [female];

Watsonia swinhoei [male]; Tagiades

waterstradti [male]; Hasora borneensis

[male]; Acerbas nitidifasciata [male];

Tagiades sambavana [male]; Hasora borneensis

[female]; Tagiades nestus Feld. [male];

Tagiades nana [male]; Ismene lara Leech

[female]; Tagiades titus Plötz; Hasora

inermis [male]; Gangara sanguinocculus

Martin; Orthophoetus lidderdali Elwes [male]

description and notes: chromolithograph; printed by West, Newman; probably by Horace Knight

article: Elwes, H.J. and James Edwards. "A revision of the oriental Hesperiidae." 14:101-324.

Plate 21: "Oriental Hesperiidae"

subject: Halpe debilis [male]; Halpe knyvetti

[male]; Parnara leechii [male]; Parnara

philippina H.-S. [male]; Halpe debilis

[female]; Halpe majuscula [male]; Halpe

fasciata [female]; Parnara philippina H.-S.

[female]; Iambrix latifascia [male]; Hasora

proxissima [male]; Parnara hasoroides [male];

Taractrocera nicevillei Wats. [male]; Halpe

beturia Hew.; Pirdana albicornis [male];

Notocrypta inornata [male]; Parnara discreta

[male]; Telicota rectifasciata [male];

Ancistroides othonias Hew.; Parnara robusta

[male]; Telicota concinna [male]; Telicota

dilutior [male]; Parnara simillima [male];

Parnara aurociliata [male]; Taractrocera

ceramas Hew. [male]; Parnara cahira Moore

[female]; Parnara subochracea Moore [male]

description and notes: chromolithograph; printed by

West, Newman; probably by Horace Knight

article: Elwes, H.J. and James Edwards. "A revision

of the oriental Hesperiidae." 14:101-324. 
Volume 20 (1912-1915)

Plate 40: "Foraminifera from the Kerimba Archipelago" subject: Nubecularia tubulosa; Nubecularia lucifuga var. decorata; Biloculina ringens var. denticulata Brady; Spiroloculina limbata d'Orbigny

description and notes: collotype; printer not noted on plate; note in article states that drawings were executed by Mabel Rhodes, W. Thornton Shiells and John R. Ford, but plates are not signed other than Huth, coll.

article: Heron-Allen, Edward and Arthur Earland. "The Foraminifera of the Kerimba Archipelago (Portuguese East Africa). Part II." 20:543-794.

Plate 41: "Foraminifera from the Kerimba Archipelago" subject: Spiroloculina planissima Lamarck; Spiroloculina crenata Karrer; Miliolina circularis var. sublineata Brady; Miliolina circularis var. cribrostoma; Miliolina tricarinata var. plicata Terquem; Miliolina tricarinata var. plicata Terquem; Miliolina tricarinata var. serrata; Miliolina terquemiana Brady; Miliolina bertheliniana Brady

description and notes: collotype; printer not noted on plate; note in article states that drawings were executed by Mabel Khodes, W. Thornton Shiells and John $k$. Ford, but plates are not signed other than Huth, coll.

article: Heron-Allen, Edward and Arthur Earland.

"The Foraminifera of the Kerimba Archipelago (Portuguese East Africa). Part II." 20:543-794.

Plate 42: "Foraminifera from the Kerimba Archipelago" subject: Miliolina cultrata Brady; Miliolina durrandii Millett; Miliolina

transversestriata Brady; Miliolina funafutiensis Chapman; Miliolina exsculpta;

Miliolina rotunda d'orbigny; Miliolina seminulum Linné; Miliolina auberiana var. stenostoma Karrer; Miliolina cuvieriana d'Orbigny; Miliolina crassa d'Orbigny; Miliolina bicostata d'Orbigny

description and notes: collotype; printer not noted on plate; note in article states that drawings were executed by Mabel Rhodes, W. Thornton Shiells and John R. Ford, but plates are not signed other than Huth, coll.

article: Heron-Allen, Edward and Arthur Earland. "The Foraminifera of the Kerimba Archipelago (Portuguese East Africa). Part II." 20:543-794. 
Plate 43: "Foraminifera from the Kerimba Archipelago" subject: Miliolina undosa Karrer; Miliolina undulata d'Orbigny; Miliolina reticulata d'Orbigny; Miliolina parkeri Brady; Miliolina kerimbatica

description and notes: collotype; printer not noted on plate; note in article states that drawings were executed by Mabel Rhodes, W. Thornton Shiells and John R. Ford, but plates are not signed other than Huth, coll.

article: Heron-Allen, Edward and Arthur Earland.

"The Foraminifera of the Kerimba Archipelago (Portuguese East Africa). Part II." 20:543-794.

Plate 44: "Foraminifera from the Kerimba Archipelago" subject: Miliolina sclerotica Karrer; Miliolina Iimbata d'Orbigny; Miliolina costata d'Orbigny; Miliolina striata d'Orbigny; Miliolina scrobiculata Brady; Miliolina triquetra Brady; Massilina secans d'Orbigny; Massilina secans var. tenuistriata Earland description and notes: collotype; printer not noted on plate; note in article states that drawings were executed by Mabel Rhodes, W. Thornton Shiells and John R. Ford, but plates are not signed other than Huth, coll.

article: Heron-Allen, Edward and Arthur Earland. "The Foraminifera of the Kerimba Archipelago (Portuguese East Africa). Part II." 20:543-794.

Plate 45: "Foraminifera from the Kerimba Archipelago" subject: Massilina secans var. reticulata; Massilina secans var. rugosa; Massilina macilenta Brady; Massilina alveoliniformis Millett; Sigmoilina ovata Sidebottom; Sigmoilina edwardsi Schlumberger; Articulina sagra d'Orbigny; Articulina conico-articulata Batsch

description and notes: collotype; printer not noted on plate; note in article states that drawings were executed by Mabel Rhodes, W. Thornton Shiells and John R. Ford, but plates are not signed other than Huth, coll.

article: Heron-Allen, Edward and Arthur Earland. "The Foraminifera of the Kerimba Archipelago (Portuguese East Africa). Part II." 20:543-794. 
Plate 46: "Foraminifera from the Kerimba Archipelago" subject: Hauerina fragilissima Brady;

Planispirina auriculata Egger; Planispirina communis Seguenza; Fischerina helix;

Cornuspira charoides; Rhapidoscene conica Vaughan Jennings; Aschemonella ramuliformis Brady; Haplophragmium compressum Goës.;

Haddonia torresiensis Chapman; Hippocrepina oviformis; Hormosina globulifera Brady; Ammodiscus gordialis Jones \& Parker; Trochammina ochracea Williamson

description and notes: collotype; printer not noted on plate; note in article states that drawings were executed by Mabel Rhodes, W. Thornton Shiells and John $\mathrm{K}$. Ford, but plates are not signed other than Huth, coll.

article: Heron-Allen, Edward and Arthur Earland.

"The Foraminifera of the Kerimba Archipelago (Fortuguese East Africa). Part II." 20:543-794.

Plate 47: "Foraminifera from the Kerimba Archipelago" subject: Textularia inconspicua Brady;

Textularia crispata Brady; Textularia rugosa

Reuss; Textularia candeiana d'Orbigny;

Textularia foliacea; Textularia hauerii

d'Orbigny; Textularia conica var. corrugata;

Textularia trochus d'Orbigny; Chrysalidina dimorpha Brady

description and notes: collotype; printer not noted on plate; note in article states that drawings were executed by Mabel Rhodes, W. Thornton Shiells and John R. Ford, but plates are not signed other than Huth, coll.

article: Heron-Allen, Edward and Arthur Earland.

"The Foraminifera of the Kerimba Archipelago (Portuguese East Africa). Part II." 20:543-794.

Plate 48: "Foraminifera from the Kerimba Archipelago" subject: Pavonina flabelliformis d'Orbigny;

Gaudryina scabra Brady; Clavulina communis d'Orbigny; Clabulina cylindrica Hantken; Clavulina angularis var. difformis Brady; Bulimina elegantissima var. compressa Millett; Bulimina squammigera d'Orbigny; Bifarina mackinnonii Millett

description and notes: collotype; printer not noted on plate; note in article states that drawings were executed by Mabel Rhodes, W. Thornton Shiells and John R. Ford, but plates are not signed other than Huth, coll.

article: Heron-Allen, Edward and Arthur Earland.

"The Foraminifera of the Kerimba Archipelago

(Portuguese East Africa). Part II." 20:543-794. 
Plate 49: "Foraminifera from the Kerimba Archipelago" subject: Virgulina schreibersiana Czjzek; Virgulina schreibersiana var. carinata; Bolivina simpsoni

description and notes: collotype; printer not noted on plate; note in article states that drawings were executed by Mabel Khodes, $W$. Thornton Shiells and John R. Ford, but plates are not signed other than Huth, coll.

article: Heron-Allen, Edward and Arthur Earland.

"The Foraminifera of the Kerimba Archipelago (Portuguese East Africa). Part II." 20:543-794.

Plate 50: "Foraminifera from the Kerimba Archipelago" subject: Bolivina limbata Brady; Mimosina rimosa; Mimosina echinata; Mimosina hystrix Millett; Cassidulina bradyi var. elongata Sidebottom; Cassidulina (Orthoplecta) clavata Brady; Lagena clavata d'Orbigny; Lagena marginato-perforata Seguenza; Lagena orbignyana var. walleriana Wright; Nodosaria spinulosa Montagu; Lagena orbignyana var.

Kerimbatica

description and notes: collotype; printer not noted on plate; note in article states that drawings were executed by Mabel Rhodes, W. Thornton Shiells and John R. Ford, but plates are not signed other than Huth, coll.

article: Heron-Allen, Edward and Arthur Earland.

"The Foraminifera of the Kerimba Archipelago (Portuguese East Africa). Part II." 20:543-794.

Plate 51: "Foraminifera from the Kerimba Archipelago" subject: Polymorphia complexa Sidebottom; Sagrina virgula Brady; Sagrina striata Schwager; Sagrina tessellata Brady; Globigerina cretacea d'Orbigny; Sphaeroidina corticata; Spirillina vivipara Ehrenberg; Spirillina ornata Sidebottom; Spirillina semidecorata; Cymbalopora milletti; Discorbina globularis d'Orbigny description and notes: collotype; printer not noted on plate; note in article states that drawings were executed by Mabel Rhodes, W. Thornton Shiells and John R. Ford, but plates are not signed other than Huth, coll.

article: Heron-Allen, Edward and Arthur Earland. "The Foraminifera of the Kerimba Archipelago (Portuguese East Africa). Part II." 20:543-794. 
Flate 52: "Foraminifera from the Kerimba Archipelago" subject: Discorbina valvulata var. granulosa; Discorbina reniformis; Discorbina vesicularis Lamarck; Discorbina polystomelloides Parker \& Jones; Discorbina pustulata Heron-Allen \& Earland; Discorbina globosa Sidebottom; Discorbina patelliformis Brady; Truncatulina rostrata Brady; Truncatulina tubulifera; Truncatulina glabra description and notes: collotype; printer not noted on plate; note in article states that drawings were executed by Mabel Rhodes, W. Thornton Shiells and John R. Ford, but plates are not signed other than Huth, coll.

article: Heron-Allen, Edward and Arthur Earland. "The Foraminifera of the Kerimba Archipelago (Portuguese East Africa). Part II." 20:543-794.

Plate 53: "Foraminifera from the Kerimba Archipelago" subject: Truncatulina echinata Brady; Anomalina polymorpha Costa; Pulvinulina lateralis Terquem; Pulvinulina partschiana d'Orbigny; Rotalia venusta Brady; Rotalia erinacea; Rotalia murrayi; Gypsina rubra d'Orbigny; Polystomella milletti

description and notes: collotype; printer not noted on plate; note in article states that drawings were executed by Mabel Rhodes, W. Thornton Shiells and John R. Ford, but plates are not signed other than Huth, coll.

article: Heron-Allen, Edward and Arthur Earland. "The Foraminifera of the Kerimba Archipelago (Portuguese East Africa). Part II." 20:543-794.

\section{Volume 21 (1916-1936)}

Plate 20

subject: Galago moholi; Homo sapiens; Potos flavus; Dactylopsila trivirgata; Oryctolagus cuniculus; Cavia porcellus [albino]; Coloelus monedula [albino]; Otus bakkamoena; Terathopius ecaudatus; Endyptes cristatus description and notes: chromolithograph; printed by John Bale Sons \& Danielsson; plate depicts irises of the species

article: Mann, Ida. "Iris pattern in the vertebrates." $21: 355-412$. 
Plate 21

subject: Dendrocygna; Phoenicopterus ruber;

Chrysemys picta; Emys orbicularis;

Osteolaemus tetraspis; Caiman crocodilus;

Gekko gekko; Pachydactylus bibronii;

Basiliscus plumifrons

description and notes: chromolithograph; printed by

John Bale Sons \& Danielsson; plate depicts

irises of the species

article: Mann, Ida. "Iris pattern in the vertebrates." $21: 355-412$.

Plate 22

subject: Physignathus cochinchinensis;

Ophryoessa superciliosa; Eumences fasciatus;

Zonurus cataphractus; Gerrhosaurus grandis;

Agama agama; Lacerta lepida; Lacerta

stehleni; Tupinambis nigropunctatus; Erginea

cunninghami; Lacerta viridis major

description and notes: chromolithograph; printed by John Bale Sons \& Danielsson; plate depicts irises of the species

article: Mann, Ida. "Iris pattern in the vertebrates." $21: 355-412$.

Plate 23

subject: Python reticulatus; Python regius;

Eryx johnii; Elaphe quadrivittata; Boiga dendrophila; Crotalus horridus; Lampropeltis getulus; Elaphe quatuorlineata; Ahaetulla picta; Passerita prasina; Triturus torosus; Bufo marinus

description and notes: chromolithograph; printed by John Bale Sons \& Danielsson; plate depicts irises of the species article: Mann, Ida. "Iris pattern in the
vertebrates." $21: 355-412$.

Plate 24

subject: Rhacophorus leucomystax; Hyperlius

horstockii; Rana temporaria; Calyptocephalus

quoyi; Hyla caerula; Tetragonopterus

rubropictus; Cyprinus carpio;

Aplocheilichthys rubrostigma; Salmo salar

description and notes: chromolithograph; printed by John Bale Sons \& Danielsson; plate depicts irises of the species

article: Mann, Ida. "Iris pattern in the vertebrates." $21: 355-412$. 
Plate 37

subject: Dendrolagus goodfellowi goodfellowi description and notes: chromolithograph; printed by John Bale Sons \& Danielsson; depicts type specimen; almost certainly drawn by F.W. Frohawk article: Rothschild, Lord. "The genus Dendrolagus." $21: 477-548$. 
SUBJECT INDEX 

Agama agama

Agama bibronii

Agama tournevillii

Ahaetulla picta

Alligator mississipensis

Alligator mississipensis

Alligator mississipensis

Alligator mississipensis

Alligator mississipensis

Alligator mississipensis

Alligator mississipensis

Apistocalamus grandis

Apistocalamus loennbergii

Atheris woosnami

Basiliscus plumifrons

Boiga dendrophila

Bombifrons indicus

Bufo marinus

Caiman crocodilus

Calyptocephalus quoyi

Carettochelys insculpta

Cerastes vipera

Ceratobatrachus guentheri

Ceratobatrachus guentheri

Ceratophrys ornata

Chalcides lineatus

Chalcides ocellatus var. polylepis

Chalcides ocellatus var. vittatus

Chamaeleo pumilus

Chamaeleo vulgaris

Chamaeleo vulgaris

Chamaeleo vulgaris

Chamaeleo vulgaris

Chamaeleon ellioti

Chamaeleon rudis

Chelys fimbriata

Chrysemys picta

Cornufer guppyi

Cornufer solomonis

Coronella amaliae

Corucia zebrata

Crocodilus intermedius

Crocodilus palustris

Crocodilus palustris

Crocodilus palustris

Crocodilus palustris

Crocodilus palustris

Crocodilus palustris

Crocodilus palustris

Crotalus horridus

Didosaurus mauritianus
Unsigned, 21: Plate 22

Smit, P., 13: Plate 14

Smit, P., 13: Plate 13

Unsigned, 21: Plate 23

Parker, M.P., 11: Plate 67

Parker, W.K., 11: Plate 62

Parker, W.K., 11: Plate 63

Parker, W.K., 11: Plate 64

Parker, W.K., 11: Plate 65

Parker, W.K., 11: Plate 66

Parker, W.K., 11: Plate 68

Green, 20: Plate 30

Green, 20: Plate 30

Green, 19: Plate 9

Unsigned, 21: Plate 21

Unsigned, 21: Plate 23

Ford, 6: Plate 31

Unsigned, 21: Plate 23

Unsigned, 21: Plate 21

Unsigned, 21: Plate 24

Green, 20: Plate 28

Smit, P., 13: Plate 18

Smit, P., 12: Plate 12

Smit, P., 12: Plate 13

Mintern, 11: Plate 46

Smit, P., 13: Plate 17

Smit, P., 13: Plate 17

Smit, P., 13: Plate 17

Parker, W.K., 11: Plate 19

Parker, W.K., 11: Plate 15

Parker, W.K., 11: Plate 16

Parker, W.K., 11: Plate 17

Parker, W.K., 11: Plate 18

Green, 19: Plate 8

Green, 19: Plate 8

Mintern, 11: Plate 42

Unsigned, 21: Plate 21

Smit, P., 12: Plate 11

Smit, P., 12: Plate 11

Smit, P., 13: Plate 18

Smit, P., 12: Plate 7

see Molinia intermedia

Parker, M.P., 11: Plate 71

Parker, W.K., 11: Plate 62

Parker, W.K., 11: Plate 64

Parker, W.K., 11: Plate 65

Parker, W.K., 11: Plate 68

Parker, W.K., 11: Plate 69

Parker, W.K., 11: Plate 70

Unsigned, 21: Plate 23

Unsigned, 13: Plate 44 
Elaphe quadrivittata

Elaphe quatuorlineata

Emys orbicularis

Erginea cunninghami

Eryx johnii

Eumeces algeriensis

Eumences fasciatus

Gekko gekko

Gerrhosaurus grandis

Gonyocephalus auritus

Gonyocephalus nigrigularis

Gymnodactylus mimikanus

Halcrosia frontata

Halcrosia nigra

Halicrosia nigra

Hoplocephalus par

Hydrophis gracilis

Hydrophis schistosa

Hyla caerula

Hyla macrops

Hyla thesaurensis

Hyla wollastoni

Hyperlius horstockii

Jacare longiscutata

Jacare ocellata

Lacerta lepida

Lacerta ocellata

Lacerta stehleni

Lacerta viridis major

Lampropeltis getulus

Laricsaurus balsami

Lepidodactylus guppyi

Liophryne kampeni

Lipinia anolis

Lissotriton punctatus

Lygosoma klossi

Lygosoma meleagris

Lygosoma mimikanum

Lygosoma nototaenia

Lygosoma oligolepis

Lygosoma tropidolepis

Lygosoma wollastoni

Mecistops cataphractus

Menopoma alleghaniensis

Menopoma alleghaniensis

Me.topoceros cornutus

Metopoceros cornutus

Micropechis ikaheka

var. fasciatus

Molge hagenmuelleri

Molinia intermedia

Nyctimantis granti

Ophryoessa superciliosa

Osteolaemus tetraspis

Pachydactylus bibronii
Unsigned, 21: Plate 23

Unsigned, 21: Plate 23

Unsigned, 21: Plate 21

Unsigned, 21: Plate 22

Unsigned, 21: Plate 23

Smit, P., 13: Plate 16

Unsigned, 21: Plate 22

Unsigned, 21: Plate 21

Unsigned, 21: Plate 22

Green, 20: Plate 28

Green, 20: Plate 28

Green, 20: Plate 28

see Halcrosia nigra

Ford, 6: Plate 31

see Halcrosia nigra

Smit, P., 12: Plate 7

Cantor, 2: Plate 56

Cantor, 2: Plate 57

Unsigned, 21: Plate 24

Smit, P., 12: Plate 11

Smit, P., 12: Plate 11

Green, 20: Plate 27

Unsigned, 21: Plate 24

Ford, 6: Plate 34

Ford, 6: Plate 33

Unsigned, 21: Plate 22

Smit, P., 13: Plate 15

Unsigned, 21: Plate 22

Unsigned, 21: Plate 22

Unsigned, 21: Plate 23

Woodward, AM, 14: Plate 1

Smit, P., 12: Plate 7

Green, 20: Plate 27

Smit, P., 12: Plate 7

Parker, W.K., 11: Plate 40

Green, 20: Plate 29

Green, 19: Plate 8

Green, 20: Plate 29

Green, 20: Plate 29

Green, 20: Plate 30

Green, 20: Plate 29

Green, 20: Plate 30

Ford, 6: Plate 32

Parker, W.K., 11: Plate 38

Parker, W.K., 11: Plate 39

Mintern, 11: Plate 43

Mintern, 11: Plate 44

Green, 20: Plate 30

Smit, P., 13: Plate 18

Ford, 6: Plate 32

Green, 20: Plate 27

Unsigned, 21: Plate 22

Unsigned, 21: Plate 21

Unsigned, 21: Plate 21 
Passerita prasina

Physignathus cochinchinens is

Psammodromus blanci

Ptyodactylus lobatus var. oudrii

Python regius

Python reticulatus

Rana bufoniformis

Rana guppyi

Rana nutti

Rana opisthodon

Rana temporaria

Rhacophorus leucomystax

Salamandra maculosa var. algira

Saurodactylus mauritanicus

Sieboldia maxima

Sieboldia maxima

Siren lacertina

Siren lacertina

Sphenodon punctatus

Sphenodon punctatus

Sphenodon punctatus

Sphenodon punctatus

Sphenodon punctatus

Sphenodon punctatus

Spnenophryne klossi

Tarentola mauritanica var. deserti

Teius rufescens

Tejus rufescens

Testudo atlas

Testudo grandidieri

Testudo grandidieri

Testudo grandidieri

Testudo indica?

Testudo inepta

Testudo sauzieri

Testudo sumeirei

Testudo sumeirei

Testudo sumeirei

Testudo triserrata

Testudo triserrata

Triton cristatus

Triton cristatus

Triturus torosus

Tupinambis nigropunctatus

Zonurus cataphractus
Unsigned, 21: Plate 23

Unsigned, 21: Plate 22

Smit, P., 13: Plate 14

Smit, P., 13: Plate 13

Unsigned, 21: Plate 23

Unsigned, 21: Plate 23

Smit, P., 12: Plate 8

Smit, P., 12: Plate 9

Green, 19: Plate 8

Smit, P., 12: Plate 10

Unsigned, 21: Plate 24

Unsigned, 21: Plate 24

Smit, P., 13: Plate 18

Smit, P., 13: Plate 13

Parker, W.K., 11: Plate 36

Parker, W.K., 11: Plate 37

Parker, W.K., 11: Plate 38

Parker, W.K., 11: Plate 39

Swinnerton, 16: Plate 1

Swinnerton, 16: Plate 2

Swinnerton, 16: Plate 3

Swinnerton, 16: Plate 4

Swinnerton, 16: Plate 5

Swinnerton, 16: Plate 6

Green, 20: Plate 27

Smit, P., 13: Plate 13

see Tejus rufescens

Mintern, 11: Plate 45

Unsigned, 13: Plate 44

Woodward, EC, 13: Plate 39

Woodward, EC, 13: Plate 40

Woodward, EC, 13: Plate 41

Unsigned, 13: Plate 42

Unsigned, 13: Plate 43

Unsigned, 13: Plate 42

Unsigned, 13: Plate 42

Unsigned, 13: Plate 43

Unsigned, 13: Plate 44

Unsigned, 13: Plate 42

Unsigned, 13: Plate 43

Parker, W.K., 11: Plate 40

Parker, W.K., 11: Plate 41

Unsigned, 21: Plate 23

Unsigned, 21: Plate 22

Unsigned, 21: Plate 22 
apteryx

apteryx

cassowary

cassowary

cassowary

cassowary

cassowary

cassowary

cas sowary

cassowary

cassowary

cassowary

cassowary

cassowary

cassowary

cassowary

cassowary

cassowary

cassowary

cassowary

cassowary

cassowary

cassowary

cassowary

curassow

curassow

curassow

curassow

curassow

curassow

curassow

curassow

curassow

curassow

curassow

curassow

curassow

curassow

dodo

dodo

dodo

dodo

dodo

eggs

quail

quail

quail

quail

Acanthorhynchus

tenuirostris

Acridotheres cinereus

Aegialites peronii

Alauda arvensis
Gould, J., 1: Plate 10

Unsigned, 1: Plate 10

Grönvold, 15: Plate 22

Grönvold, 15: Plate 23

Grönvold, 15: Plate 24

Grönvold, 15: Plate 25

Grönvold, 15: Plate 26

Grönvold, 15: Plate 27

Grönvold, 15: Plate 28

Grönvold, 15: Plate 29

Grönvold, 15: Plate 30

Grönvold, 15: Plate 31

Grönvold, 15: Plate 32

Grönvold, 15: Plate 33

Grönvold, 15: Plate 34

Grönvold, 15: Plate 35

Grönvold, 15: Plate 36

Grönvold, 15: Plate 37

Grönvold, 15: Plate 38

Grönvold, 15: Plate 39

Grönvold, 15: Plate 42

Grönvold, 15: Plate 43

Grönvold, 15: Plate 44

Grönvold, 15: Plate 45

Smit, 9: Plate 40

Smit, 9: Plate 41

Smit, 9: Plate 42

Smit, 9: Plate 43

Smit, 9: Plate 44

Smit, 9: Plate 45

Smit, 9: Plate 46

Smit, 9: Plate 47

Smit, 9: Plate 48

Smit, 9: Plate 49

Smit, 9: Plate 50

Smit, 9: Plate 51

Smit, 9: Plate 52

Smit, 9: Plate 53

Erxleben, 3: Plate 38

Erxleben, 7: Plate 64

Erxleben, 7: Plate 65

Unsigned, 13: Plate 36

Unsigned, 13: Plate 37

Grönvold, 19: Plate 19

Gould, J., 2: Plate 1

Gould, J., 2: Plate 2

Gould, J., 2: Plate 3

Gould, J., 2: Plate 4

Parker, 10: Plate 47

Smit, 8: Plate 10

Smit, 8: Plate 10

Parker, 10: Plate 50 
Alca impennis

Alca impennis

Alethe carruthersi

Alethe woosnami

Amaurornis olivacea

Amblyospiza melanonota

Anaeretes parulus

Anas theodori

Anomolopteryx didiformis Anomolopteryx didiformis

Anomolopteryx didiformis Anthoscopus roccatii

Anthreptes malaccensis

Anthropoides stanleyanus

Anthus leggei

Apails aftinis

Apalis denti

Apalis ruwenzorii

Aphanapteryx broekei

Apteryx

Apteryx

Apteryx

Apteryx

Apteryx

Apteryx

Apteryx

Apteryx

Apteryx

Apteryx australis

Apteryx australis

Apteryx australis

Apteryx australis

Apteryx australis

Apteryx australis

Apteryx australis

Apteryx australis

Apteryx australis

Apteryx australis

Apteryx australis

Apteryx australis

Apteryx australis

Apteryx australis

Apteryx australis

Apteryx australis

Apteryx australis

Apteryx australis

Apteryx australis

Apteryx australis

Apteryx australis mantelli

Apteryx mantelli

Apteryx mantelli

Apteryx oweni

Apteryx owenii

Aptornis

Aptornis defossor
Smith, 5: Plate 51

Smith, 5: Plate 52

Grönvold, 19: Plate 15

Grönvold, 19: Plate 15

Smit, 9: Plate 33

Grönvold, 19: Plate 19

Parker, 9: Plate 59

Unsigned, 13: Plate 34

Hamilton, 13: Plate 62

Parker, T.J., 13: Plate 59

Parker, T.J., 13: Plate 61

Grönvold, 19: Plate 13

Parker, 10: Plate 53

Parker, 10: Plate 54

Grönvold, 19: Plate 13

Grönvold, 19: Plate 14

Grönvold, 19: Plate 14

Grönvold, 19: Plate 14

Unsigned, 13: Plate 35

Erxleben, 3: Plate 18

Erxleben, 3: Plate 18a

Erxleben, 3: Plate 29

Erxleben, 3: Plate 39

Erxleben, 3: Plate 43

Erxleben, 3: Plate 49

Erxleben, 3: Plate 50

Hamilton, 13: Plate 62

Scharf, H., 2: Plate 53

Clift, 2: Plate 49

Clift, 2: Plate 51

Clift, 2: Plate 52

Erxleben, 4: Plate 2

Gould, J., 1: Plate 10

Grönvold, 15: Plate 42

Owen, 3: Plate 31

Owen, 3: Plate 32

Owen, 3: Plate 33

Owen, 3: Plate 34

Owen, 3: Plate 35

Owen, 7: Plate 45

Owen, 7: Plate 46

Scharf, H., 2: Plate 47

Scharf, H., 2: Plate 48

Scharf, H., 2: Plate 50

Scharf, H., 2: Plate 54

Scharf, H., 2: Plate 55

Unsigned, 1: Plate 10

Unsigned, 3: Plate 36

Grönvold, 15: Plate 43

Grönvold, 15: Plate 43

Grönvold, 15: Plate 45

Grönvold, 15: Plate 43

Richter, 3: Plate 57

Erxleben, 7: Plate 42

Erxleben, 7: Plate 40 
Aptornis defossor Aptornis defossor Aptornis defossor Aptornis defossor Aptornis defossor Aptornis defossor Aptornis defossor Aptornis didiformis Aptornis otidiformis Aptornis otidiformis Aquila desmursi Ara ararauna

Ara macao Ara macao Argala

Artamus leucorhinus Artamus monachus Astur alphonsi

Athene

Balaeniceps rex

Balaeniceps rex

Balaeniceps rex

Balaeniceps rex

Bat is diops

Bernicla ruficollis

Bleda woosnami

Bolborhynchus lineolatus

Bradypterus alfredi

Bradypterus barakae

Brotogerys pyrrhopterus

Bubo africanus

Bubo ketupa

Bubo maximus

Buceros cavatus

Buceros exaratus

Budytes rayi

Buteo fuliginosus

Buteo zonocercus

Butorides mauritianus

Cacatua ducorpsii

Cacatua galerita

Cacatua galerita

Cacatua galerita

Calodromas elegans

Camarhynchus habeli

Camarhynchus variegatus

Camaroptera griseoviridis

Cancroma cochlearia

Cancroma cochlearia

Caprimulgus fossei

Caprimulgus inornatus

Cardinalis virginiana

Casuarius

Casuarius

Casuarius australis
Erxleben, 7: Plate 41

Erxleben, 7: Plate 43

Erxleben, 7: Plate 44

Erxleben, 8: Plate 14

Erxleben, 8: Plate 15

Owen, 7: Plate 46

Owen, 8: Plate 16

Erxleben, 5: Plate 65

Erxleben, 4: Plate 3

Erxleben, 7: Plate 44

Wolf, J., 4: Plate 77

Grönvold, 16: Plate 28

Grönvold, 16: Plate 27

Grönvold, 16: Plate 28

Erxleben, 3: Plate 45

Parker, 9: Plate 58

Smit, 8: Plate 6

Unsigned, 13: Plate 33

Jennens, 4: Plate 56

Erxleben, 4: Plate 65

Erxleben, 4: Plate 66

Erxleben, 4: Plate 67

Wolf, J., 4: Plate 64

Grönvold, 19: Plate 18

Witthoos, 6: Plate 62

Grönvold, 19: Plate 17

Grönvold, 16: Plate 29

Grönvold, 19: Plate 16

Grönvold, 19: Plate 16

Grönvold, 16: Plate 28

Jennens, 4: Plate 57

Jennens, 4: Plate 57

Grönvold, 15: Plate 43

Owen, 1: Plate 18

Smit, 8: Plate 5

Parker, 10: Plate 52

Wolf, J., 4: Plate 62

Wolf, J., 4: Plate 59

Unsigned, 13: Plate 34

Berjeau, 7: Plate 56

Grönvold, 16: Plate 26

Grönvold, 16: Plate 27

Grönvold, 16: Plate 28

Grönvold, 15: Plate 45

Keulemans, 9: Plate 86

Keulemans, 9: Plate 85

Grönvold, 19: Plate 19

Berjeau, 7: Plate 56

Berjeau, 7: Plate 57

Grönvold, 19: Plate 19

Smit, 7: Plate 24

Parker, 10: Plate 48

Erxleben, 3: Plate 43

Hamilton, 13: Plate 62

Grönvold, 15: Plate 45 
Casuarius bennetti

Casuarius bennettii

Casuarius bicarunculatus

Casuarius bicarunculatus

Casuarius casuarius

Casuarius casuarius

Casuarius casuarius australis

Casuarius casuarius beccarii

Casuarius casuarius intensus

Casuarius casuarius salvadorii

Casuarius casuarius violicollis

Casuarius galeatus

Casuarius galeatus

Casuarius galeatus

Casuarius loriae

Casuarius papuanus

Casuarius papuanus edwardsi

Casuarius philipi

Casuarius picticollis

Casuarius picticollis hecki

Casuarius sclateri

Casuarius unappendiculatus

Casuarius unappendiculatus

Casuarius uniappendiculatus

Casuarius uniappendiculatus

Casuarius uniappendiculatus

Casuarius uniappendiculatus aurantiacus

Casuarius uniappendiculatus occipitalis

Cereopsis

Chamaeopelia passernia Chasmorhynchus nudicollis Chelidon urbica

Chizaerhis leucogaster Chizaerhis personata Chloropeta gracilirostris Chlorophanes atricapilla Chrysotis ochrocephala Chrysotis ochrocephala Chrysotis panamensis Ciccaba nigro-lineata Cinnyris cupreus
Keulemans, 15: Plate 39 Jury, 4: Plate 72

Jury, 4: Plate 73

Keulemans, 15: Plate 28 Grönvold, 15: Plate 45

Keulemans, 15: Plate 22

Keulemans, 15: Plate 25

Keulemans, 15: Plate 23

Keulemans, 15: Plate 27

Keulemans, 15: Plate 24

Keulemans, 15: Plate 26 Erxleben, 3: Plate 30 Jury, 4: Plate 71

Owen, 7: Plate 46

Keulemans, 15: Plate 38

Keulemans, 15: Plate 34

Keulemans, 15: Plate 35 Keulemans, 15: Plate 33 Keulemans, 15: Plate 36

Keulemans, 15: Plate 37 Grönvold, 15: Plate 44 Grönvold, 15: Plate 44 Grönvold, 15: Plate 45

Jury, 4: Plate 74

Keulemans, 15: Plate 29

Keulemans, 15: Plate 30

Keulemans, 15: Plate 32

Keulemans, 15: Plate 31 Erxleben, 12: Plate 28

Parker, W.K., 5: Plate 34

Parker, 9: Plate 62

Parker, 10: Plate 52

Vogel, 3: Plate 17

Vogel, 3: Plate 16

Grönvold, 19: Plate 18

Parker, 10: Plate 48

Grönvold, 16: Plate 27

Grönvold, 16: Plate 28

Grönvold, 16: Plate 27

Wolf, J., 4: Plate 63

Grönvold, 19: Plate 19 
Cisticola chubbi

Cisticola erythrops

Cnemiornis

Cnemiornis

Cnemiornis

Cnemiornis

Cnemiornis calcitrans

Cnemiornis calcitrans

Cnemiornis calcitrans

Cnemiornis calcitrans

Cnemiornis calcitrans

Cnemiornis calcitrans

Cnemiornis calcitrans

Coccothraustes vulgaris

Coloelus monedula

Columba livia

Conurus cactorum

Conurus jendaya

Conurus jendaya

Copsychus mindanensis

Coracopsis vasa

Coracopsis vasa

Coraphites melanauchen

Corvus corone

Corvus frugilegus

Cossypha archeri

Coturnix argoondah

Coturnix erythrorhyncha

Coturnix pentah

Coturnix taigoor

Cranorrhinus leucocephalus

Crax alberti

Crax alector

Crax carunculata

Crax daubentoni

Crax daubentoni

Crax erythrognatha

Crax globicera

Crax globicera

Crax globulosa

Crax globulosa

Crax incommoda

Crax incommoda

Crax salvini

Crax sclateri

Crax sclateri

Crax urumutum

Crax viridirostris

Cryptolopha alpina

Cryptolopha alpina

Cryptospiza salvadorii

Cyclorhis

Cygnus falconeri

Cygnus musicus?

Cygnus olor
Grönvold, 19: Plate 19

Grönvold, 19: Plate 19

Erxleben, 7: Plate 42

Owen, 9: Plate 35

Owen, 9: Plate 37

Owen, 9: Plate 38

Erxleben, 5: Plate 63

Erxleben, 5: Plate 64

Erxleben, 5: Plate 65

Erxleben, 5: Plate 66

Erxleben, 5: Plate 67

Owen, 9: Plate 36

Owen, 9: Plate 39

Parker, 10: Plate 50

Unsigned, 21: Plate 20

Parker, W.K., 5: Plate 37

Grönvold, 16: Plate 28

Grönvold, 16: Plate 26

Grönvold, 16: Plate 28

Smit, 9: Plate 33

Grönvold, 16: Plate 27

Grönvold, 16: Plate 28

Smit, 7: Plate 26

Parker, 9: Plate 55

Parker, 9: Plate 55

Grönvold, 19: Plate 16

Gould, J., 2: Plate 2

Gould, J., 2: Plate 1

Gould, J., 2: Plate 3

Gould, J., 2: Plate 4

Smit, 9: Plate 27

Smit, 9: Plate 48

Smit, 9: Plate 43

Smit, 9: Plate 47

Smit, 9: Plate 41

Smit, 9: Plate 42

Smit, 10: Plate 90

Smit, 10: Plate 89

Smit, 9: Plate 40

Smit, 10: Plate 91

Smit, 9: Plate 46

Smit, 10: Plate 93

Smit, 9: Plate 49

Smit, 10: Plate 95

Smit, 9: Plate 44

Smit, 9: Plate 45

Smit, 10: Plate 94

Smit, 10: Plate 92

Grönvold, 19: Plate 12

Grönvold, 19: Plate 19

Grönvold, 19: Plate 11

Parker, 10: Plate 51

Erxleben, 6: Plate 30

Erxleben, 6: Plate 30

Erxleben, 6: Plate 30 
Cyornis rufigula

Cypselus apus

Dasornis londinensis

Dendraeca pennsylvanica

Dendrocilla leucogastra

Dendrocolaptes albicollis

Dendrocygna

Dicrurus balicassius

Dicrurus leucops

Didunculus strigirostris

Didus

Didus

Didus?

Didus ineptus

Didus ineptus

Didus ineptus

Didus ineptus

Didus ineptus

Didus ineptus

Didus ineptus

Didus ineptus

Didus ineptus

Didus ineptus

Didus ineptus

Didus ineptus

Didus ineptus

Didus ineptus

Didus ineptus

Didus ineptus

Dinornis

Dinornis

Dinornis

Dinornis

Dinornis

Dinornis

Dinornis

Dinornis

Dinornis

Dinornis

Dinornis

Dinornis

Dinornis aeranoides

Dinornis casuarinus

Dinornis casuarinus

Dinornis casuarinus

Dinornis casuarinus

Dinornis casuarinus

Dinornis crassus

Dinornis crassus

Dinornis crassus

Dinornis crassus

Dinornis crassus

Dinornis crassus

Dinornis curtus

Dinornis curtus
Smit, 8: Plate 7

Parker, 10: Plate 52

Erxleben, 7: Plate 16

Parker, 10: Plate 48

Unsigned, 1: Plate 12

Parker, 9: Plate 59

Unsigned, 21: Plate 21

Smit, 9: Plate 31

Parker, 9: Plate 58

Erxleben, 6: Plate 15

Erxleben, 3: Plate 49

Erxleben, 3: Plate 50

Witthoos, 6: Plate 62

Erxleben, 3: Plate 38

Erxleben, 6: Plate 15

Erxleben, 6: Plate 17

Erxleben, 6: Plate 20

Erxleben, 6: Plate 24

Erxleben, 7: Plate 64

Erxleben, 7: Plate 65

Ford, 7: Plate 66

Robinson, 6: Plate 16

Robinson, 6: Plate 18

Smit, 6: Plate 19

Smit, 6: Plate 21

Smit, 6: Plate 22

Smit, 6: Plate 23

Unsigned, 13: Plate 36

Unsigned, 13: Plate 37

Erxleben, 3: Plate 18

Erxleben, 3: Plate 18a

Erxleben, 3: Plate 19

Erxleben, 3: Plate 20

Erxleben, 3: Plate 28

Erxleben, 3: Plate 29

Erxleben, 3: Plate 43

Erxleben, 3: Plate 52

Erxleben, 3: Plate 53

Hamilton, 13: Plate 62

Scharf, G., 3: Plate 25

Scharf, G., 3: Plate 26

Erxleben, 5: Plate 65

Erxleben, 3: Plate 46

Erxleben, 3: Plate 47

Erxleben, 3: Plate 48

Smit, 7: Plate 13

Smit, 7: Plate 13

Erxleben, 3: Plate 48

Erxleben, 4: Plate 45

Erxleben, 7: Plate 11

Erxleben, 7: Plate 47

Smit, 10: Plate 31

Erxleben, 3: Plate 42

Erxleben, 3: Plate 47

Erxleben, 3: Plate 48 


Dinornis curtus
Dinornis didiformis
Dinornis didiformis
Dinornis didiformis
Dinornis didiformis
Dinornis didinus
Dinornis didinus
Dinornis didinus
Dinornis dromioides
Dinornis dromioides
Dinornis dromioides
Dinornis dromioides
Dinornis dromioides
Dinornis elephantopus
Dinornis elephantopus
Dinornis elephantopus
Dinornis elephantopus
Dinornis elephantopus
Dinornis elephantopus
Dinornis elephantopus
Dinornis elephantopus
Dinornis elephantopus
Dinornis elephantopus?
Dinornis geranoides
Dinornis geranoides
Dinornis giganteus
Dinornis giganteus
Dinornis giganteus
Dinornis giganteus
Dinornis giganteus
Dinornis giganteus
(pullus ?
Dinornis gigantus
Dinornis gigas
Dinornis gigas
Dinornis gracilis
Dinornis gracilis
Dinornis gravis
Dinornis gravis
Dinornis gravis
Dinornis gravis
Dinornis gravis
Dinornis ingens
Dinornis ingens
Dinornis ingens
Dinornis ingens
Dinornis ingens
Dinornis ingens
Dinornis ingens
Dinornis ingens?
Dinornis ingens?
Dinornis maximus
Dinornis maximus
Dinornis maximus

Erxleben, 7: Plate 44 Erxleben, 3: Plate 30 Scharf, G., 3: Plate 20a Scharf, G., 3: Plate 24 Visoisf, 3: Plate 27 Erxleben, 11: Plate 59 Erxleben, 11: Plate 60 Erxleben, 11: Plate 61 Erxleben, 3: Plate 39 Erxleben, 3: Plate 48 Scharf, G., 3: Plate 21 Scharf, G., 3: Plate 22 Scharf, G., 3: Plate 23 Dinkel, 4: Plate 43 Erxleben, 12: Plate 1 Erxleben, 4: Plate 44 Erxleben, 4: Plate 45 Erxleben, 4: Plate 46 Erxleben, 4: Plate 47 Erxleben, 7: Plate 7 Owen, 7: Plate 46 Smit, 7: Plate 10 Erxleben, 7: Plate 47 Erxleben, 5: Plate 65 Erxleben, 5: Plate 67 Erxleben, 3: Plate 30 Erxleben, 3: Plate 40 Owen, 7: Plate 45 Scharf, G., 3: Plate 41 Visoisf, 3: Plate 27

Erxleben, 4: Plate 24 Erxleben, 3: Plate 44 Erxleben, 3: Plate 39 Erxleben, 3: Plate 45 Erxleben, 4: Plate 41 Erxleben, 4: Plate 42 Erxleben, 8: Plate 58 Erxleben, 8: Plate 59 Erxleben, 8: Plate 60 Erxleben, 8: Plate 61 Smit, 7: Plate 14 Erxleben, 3: Plate 30 Erxleben, 3: Plate 40 Erxleben, 3: Plate 42 Erxleben, 3: Plate 48 Owen, 7: Plate 15 Owen, 7: Plate 46 Scharf, G., 3: Plate 21 Erxleben, 4: Plate 24 Erxleben, 7: Plate 47 Dinke1, 6: Plate 89 Dinkel, 6: Plate 90 Griesbach, 10: Plate 32 Smit, 10: Plate 31 
Dinornis oweni

Dinornis oweni

Dinornis parvus

Dinornis parvus

Dinornis parvus

Dinornis parvus

Dinornis parvus

Dinornis parvus

Dinornis parvus

Dinornis parvus

Dinornis rheides

Dinornis rheides

Dinornis rheides

Dinornis rheides

Dinornis rheides

Dinornis robustus

Dinornis robustus

Dinornis robustus

Dinornis robustus

Dinornis robustus

Dinornis robustus

Dinornis robustus?

Dinornis struthioides

Dinornis struthioides

Dinornis struthioides

Dinornis struthoides

Dinornis struthoides

Dinornis struthoides

Dinornis struthoides

Dinornis torosus

Dinornis torosus

Dromaeus

Dromaeus ater

Dromaeus irroratus

Dromaeus irroratus?

Dromaeus novae-hollandiae

Dromaeus novae-hollandiae

Dromaeus novae-hollandiae

Dromaeus novae-hollandiae

Dromaeus novae-hollandiae

Dromaius

Dromaius

Dromaius

Dromaius novae-hollandiae

Dromornis australis

Eclectus pectoralis

Elainea

Emberiza citrinella

Emberiza flaviventris

Emberiza flaviventris

Emberiza miliaria

Emeus

Emeus sp. alpha

Emeus sp. alpha

Emeus sp. alpha
Erxleben, 12: Plate 31

Erxleben, 12: Plate 32

Erxleben, 11: Plate 51

Erxleben, 11: Plate 52

Erxleben, 11: Plate 53

Erxleben, 11: Plate 54

Erxleben, 11: Plate 55

Erxleben, 11: Plate 56

Erxleben, 11: Plate 57

Erxleben, 11: Plate 58

Erxleben, 4: Plate 3

Erxleben, 7: Plate 47

Erxleben, 7: Plate 8

Erxleben, 7: Plate 9

Smit, 7: Plate 12

Dinkel, 6: Plate 88

Erxleben, 4: Plate 47

Erxleben, 5: Plate 53

Erxleben, 5: Plate 54

Erxleben, 5: Plate 55

Erxleben, 5: Plate 56

Erxleben, 7: Plate 47

Erxleben, 3: Plate 38

Erxleben, 4: Plate 41

Erxleben, 4: Plate 42

Erxleben, 3: Plate 30

Scharf, G., 3: Plate 21

Scharf, G., 3: Plate 23

Visoisf, 3: Plate 27

Hamilton, 13: Plate 62

Parker, T.J., 13: Plate 61

Hamilton, 13: Plate 62

Grönvold, 15: Plate 44

Jury, 4: Plate 76

Grönvold, 15: Plate 43

Grönvold, 15: Plate 42

Grönvold, 15: Plate 43

Grönvold, 15: Plate 44

Grönvold, 15: Plate 45

Jury, 4: Plate 75

Erxleben, 3: Plate 39

Erxleben, 3: Plate 43

Erxleben, 3: Plate 45

Erxleben, 8: Plate 59

Erxleben, 10: Plate 33

Grönvold, 16: Plate 29

Parker, 9: Plate 61

Parker, 10: Plate 49

Grönvold, 19: Plate 19

Grönvold, 19: Plate 19

Parker, 10: Plate 49

Grönvold, 15: Plate 43

Hamilton, 13: Plate 62

Parker, T.J., 13: Plate 57

Parker, T.J., 13: Plate 59 


Emeus sp. alpha
Emeus sp. beta
Emeus sp. beta
Emeus sp. lambda
Emeus sp. lambda
Emeus crassus
Emeus crassus
Endyptes cristatus
Enodes erythrophrys
Eos riciniata
Eos riciniata
Erythrocercus congicus
Estrelda astrild
Euphonia violacea
Eurylaimus lunatus
Eurypyga helias
Eurypyga helias
Fregilus graculus
Fulica newtoni
Gastornis klaasseni
Gastornis klaasseni
Geocichla erythronota
Geocichla piaggae
Geothlypis trichas
Glaucidium ferrugineum
Grallaria squamigera
Graucalus striatus
Graucalus temmincki
Gymorhina tibicen
Haliaeetus
Haliaeetus
Hemipodius sp.?
Hemipodius varius
Hemipodius varius
Hieroccoccyx crassirostris
Homorus unicolor
Hyloterpe philippensis
Hyloterpe sulfuriventer
Hyphantornis jacksoni
Hyphantornis jacksoni
Hypothymis puella
Ibis
Icterus sp.?
Icterus vuigaris
leraglaux connivens
Lagopus scoticus
Lalage leucopygialis
Lalage leucopygialis
Laniarius erythrogaster
Lanius collurio
Lanius fallax
Lanius lucionensis
Larus argentatus
Larus fuliginosus
Larus hemprichii

Parker, T.J., 13: Plate 61 Hamilton, 13: Plate 62 Parker, T.J., 13: Plate 61 Hamilton, 13: Plate 62 Parker, T.J., 13: Plate 61 Hamilton, 13: Plate 62 Parker, T.J., 13: Plate 61 Unsigned, 21: Plate 20 Parker, 9: Plate 58 Grönvold, 16: Plate 26 Grönvold, 16: Plate 29 Grönvold, 19: Plate 14 Parker, 10: Plate 50 Parker, 10: Plate 46 Gould, J., 1: Plate 25 Berjeau, 7: Plate 57 Parker, 10: Plate 54 Parker, 9: Plate 55 Unsigned, 13: Plate 35 Erxleben, 12: Plate 28

Erxleben, 12: Plate 29

Smit, 8: Plate 6 Grönvold, 19: Plate 19

Parker, 10: Plate 48 Jennens, 4: Plate 56 Parker, 9: Plate 56 Smit, 9: Plate 30 Smit, 8: Plate 12 Parker, 9: Plate 60 Erxleben, 3: Plate 49 Erxleben, 3: Plate 50 Parker, W.K., 5: Plate 34 Parker, 9: Plate 54 Parker, W.K., 5: Plate 35 Smit, 8: Plate 13

Parker, 9: Plate 60

Smit, 9: Plate 31

Parker, 9: Plate 58 Grönvold, 19: Plate 19 Grönvold, 19: Plate 19

Smit, 8: Plate 7

Scharf, H., 2: Plate 53

Parker, 10: Plate 49

Parker, 10: Plate 49 Jennens, 4: Plate 56

Parker, W.K., 5: Plate 36

Parker, 9: Plate 62

Smit, 8: Plate 8

Grönvold, 19: Plate 19

Parker, 9: Plate 61

Smit, 7: Plate 25

Smit, 9: Plate 29

Erxleben, 12: Plate 28

Keulemans, 9: Plate 87

Smit, 7: Plate 27 
Lempijius megalotis

Leucotreron gironieri

Limnaëtus philippensis

Linaria chloris

Liothrix

Lophopsittacus mauritianus

Loriculus galgulus

Loriculus galgulus

Loriculus galgulus

Lorius domicella

Lorius domicella

Lorius domicella

Lorius flavo-palliatus

Macheirhamphus alcinus

Malimbus fagani

Megalapteryx hectori

Menura superba

Merops bicolor

Merops sumatranus

Mesopteryx sp. alpha

Mesopteryx sp. alpha

Mesopteryx sp. beta

Mesopteryx sp. beta

Mesopteryx sp. lambda

Mesopteryx sp. lambda

Mesopteryx casuarina

Mesopteryx casuarina

Micropterus cinereus

Micropterus cinereus

Micropterus cinereus

Micropterus cinereus

Micropterus cinereus

Mitua tomentosa

Mitua tuberosa

Mniotilta varia

Motacilla yarrelli

Munia brunneiceps

Muscicapa grisola

Muscisaxicola mentalis

Myialestes helianthea

Nasiterna pusio

Nectarinia dartmouthi

Nectarinia kilimensis

Nectarophila grayi

Neisna nyansae

Nesocharis ansorgei

Nestor

Nestor notabilis

Nestor notabilis

Ninox philippensis

Nothocrax urumutum

Notornis

Notornis

Notornis mantel1i

Notornis mantelli
Smit, 9: Plate 25

Smit, 9: Plate 34

Smit, 9: Plate 24

Parker, 10: Plate 50

Parker, 10: Plate 52

Unsigned, 13: Plate 33

Grönvold, 16: Plate 27

Grönvold, 16: Plate 29

Grönvold, 16: Plate 29

Grönvold, 16: Plate 27

Grönvold, 16: Plate 29

Grönvold, 16: Plate 29

Grönvold, 16: Plate 29

Wolf, 6: Plate 29

Grönvold, 19: Plate 10

Blair, 12: Plate 30

Parker, 9: Plate 56

Smit, 9: Plate 26

Smit, 9: Plate 26

Hamilton, 13: Plate 62

Parker, T.J., 13: Plate 61

Hamilton, 13: Plate 62

Parker, T.J., 13: Plate 61

Hamilton, 13: Plate 62

Parker, T.J., 13: Plate 61

Hamilton, 13: Plate 62

Parker, T.J., 13: Plate 61

Smit, 7: Plate 58

Smit, 7: Plate 59

Smit, 7: Plate 60

Smit, 7: Plate 61

Smit, 7: Plate 62

Smit, 9: Plate 52

Smit, 9: Plate 51

Parker, 10: Plate 48

Parker, 10: Plate 52

Smit, 8: Plate 9

Parker, 10: Plate 52

Parker, 9: Plate 59

Smit, 8: Plate 7

Grönvold, 16: Plate 29

Grönvold, 19: Plate 12

Grönvold, 19: Plate 19

Parker, 10: Plate 53

Grönvold, 19: Plate 10

Grönvold, 19: Plate 11

Erxleben, 3: Plate 53

Grönvold, 16: Plate 27

Grönvold, 16: Plate 29

Smit, 9: Plate 25

Smit, 9: Plate 50

Dinkel, 3: Plate 56

Erxleben, 7: Plate 42

Erxleben, 4: Plate 2

Erxleben, 4: Plate 4 
Notornis mantellii

Ocydromus australis

Oedicnemus vermiculatus

Oestrelata phaeopygia

Opisthocomus cristatus

Opisthocomus cristatus

Opisthocomus cristatus

Opisthocomus cristatus

Opisthocomus cristatus

Opisthocomus cristatus

Opisthocomus cristatus

Opisthocomus cristatus

Oriolus galbula

Otis

Otus bakkamoena

Otus brachyotus

Otus vulgaris

Pachycephala fusca(?)

Pachyornis sp. alpha

Pachyornis sp. alpha

Pachyornis elephantopus

Pachyornis elephantopus

Pachyrhamphus

Paeocephalus rüppelli

Palaeornis torquata

Palaeornis torquata

Palapteryx

Palapteryx

Palapteryx

Palapteryx

Palapteryx

Palapteryx dromioides

Palapteryx dromioides

Palapteryx robustus

Panurus biarmicus

Paradisea papuana

Parus ater

Parus major

Pauxi galeata

Pauxis galeata var. rubra

Pelecanus

Pelecanus

Penelopides panini

Perdix cinerea

Petroica bicolor

Petroica monticola

Pezophaps minor

Pezophaps solitaria

Pezoporus formosus

Pezoporus formosus

Phalacrocorax

Phalacrocorax

Phalacrocorax

Phapitreron amethystina
Wolf, J., 4: Plate 25

Owen, 8: Plate 16

Grönvold, 19: Plate 19

Keulemans, 9: Plate 88

Parker, W.K., 13: Plate 10

Parker, W.K., 13: Plate 7

Parker, W.K., 13: Plate 8

Parker, W.K., 13: Plate 9

Smit, 9: Plate 63

Smit, 9: Plate 64

Smit, 9: Plate 65

Smit, 9: Plate 66

Parker, 10: Plate 52

Erxleben, 3: Plate 52

Unsigned, 21: Plate 20

Jennens, 4: Plate 56

Jennens, 4: Plate 57

Parker, 9: Plate 61

Hamilton, 13: Plate 62

Parker, T.J., 13: Plate 61

Hamilton, 13: Plate 62

Parker, T.J., 13: P1ate 61

Parker, 9: Plate 57

Grönvold, 16: Plate 26

Grönvold, 16: Plate 26

Grönvold, 16: Plate 28

Erxleben, 3: Plate 53

Erxleben, 3: Plate 54

Erxleben, 3: Plate 55

Erxleben, 4: Plate 24

Erxleben, 4: Plate 4

Erxleben, 3: Plate 47

Erxleben, 4: Plate 2

Erxleben, 4: Plate 1

Parker, 10: Plate 51

Parker, 9: Plate 62

Parker, 10: Plate 51

Parker, 10: Plate 51

Smit, 9: Plate 53

Smit, 9: Plate 53

Wesley, 10: Plate 55

Wesley, 10: Plate 59

Smit, 9: Plate 28

Erxleben, 5: Plate 41

Parker, 9: Plate 60

Parker, 9: Plate 60

Ford, 7: Plate 66

Ford, 7: Plate 66

Grönvold, 16: Plate 26

Grönvold, 16: Plate 29

Wesley, 10: Plate 57

Wesley, 10: Plate 60

Wesley, 10: Plate 61

Smit, 9: Plate 34 
Philentoma cyaniceps Phoenicopterus ruber Pholidornis denti Phororhacos inflatus Phororhacos inflatus Phororhacos inflatus Phororhacos inflatus Phrygilus fruticeti Phyllanthus czarnikowi Phytotoma rara

Pionopsittacus pileatus

Pipra auricapilla

Pitta melanocephala

Platycercus eximius

Platycercus eximius

Platycercus eximius

Plectrophanes nivalis

Plotus

Plotus

Plotus nanus

Porphyrio

Pratincola rubetra

Prionochilus aureolimbatus

Procellaria tethys

Pseudolalage melanoleuca

Pseudoptynx philippensis

Psittacula passerina

Psittacus erithacus

Psittacus erithacus

Psittacus erithacus

Psittacus erithacus

Psittinus incertus

Pternistes cranchi

Ptilotis

Ptistes erythropterus

Ptistes erythropterus

Pycnonotus urostictus

Pyranga rubra

Pyromelana crassirostris

Pyrrhura leucotis

Pyrrhura leucotis

Pytelia belli

Rhea

Rhea

Rhea americana

Rhea americana

Rhea americana

Rhea americana

Rhea americana

Rhea americana

Rhea darwinii

Rhea macrorhyncha

Rhinochetus jubatus

Rhinochetus jubatus

Rhinochetus jubatus
Smit, 9: Plate 32

Unsigned, 21: Plate 21

Grönvold, 19: Plate 13

Green, 15: Plate 14

Green, 15: Plate 15

Green, 15: Plate 16

Green, 15: Plate 17

Parker, 10: Plate 49

Grönvold, 19: Plate 17

Parker, 10: Plate 46

Grönvold, 16: Plate 29

Parker, 9: Plate 57

Parker, 9: Plate 56

Grönvold, 16: Plate 26

Grönvold, 16: Plate 26

Grönvold, 16: Plate 29

Parker, 10: Plate 49

Wesley, 10: Plate 58

Wesley, 10: Plate 61

Unsigned, 13: Plate 34

Dinkel, 3: Plate 56

Parker, 10: Plate 52

Parker, 10: Plate 46

Keulemans, 9: Plate 88

Smit, 9: Plate 29

Smit, 9: Plate 25

Grönvold, 16: Plate 29

Grönvold, 16: Plate 26

Grönvold, 16: Plate 27

Grönvold, 16: Plate 27

Grönvold, 16: Plate 28

Grönvold, 16: Plate 28

Grönvold, 19: Plate 19

Parker, 10: Plate 47

Grönvold, 16: Plate 26

Grönvold, 16: Plate 28

Smit, 9: Plate 32

Parker, 10: Plate 46

Grönvold, 19: Plate 10

Grönvold, 16: Plate 27

Grönvold, 16: Plate 29

Grönvold, 19: Plate 11

Erxleben, 3: Plate 43

Hamilton, 13: Plate 62

Grönvold, 15: Plate 42

Grönvold, 15: Plate 43

Grönvold, 15: Plate 45

Jury, 4: Plate 68

Parker, W.K., 5: Plate 42

Scharf, H., 2: Plate 47

Jury, 4: Plate 70

Jury, 4: Plate 69

Berjeau, 7: Plate 56

Berjeau, 7: Plate 57

Erxleben, 6: Plate 91 
Rhinochetus jubatus

Ruticilla phoenicurus

Sarcidiornis mauritiana

Scops usta

Sereopsis

Sereopsis

Sereopsis

Sereopsis

Sereopsis

Sericornis humilis(?)

Sitagra aliena

Sitta europaea

Sittella

Spermospiza poliogenys

Spheniscus mendiculus

Stephanophorus

leucocephalus

Stringops habroptilus

Stringops habroptilus

Stringops habroptilus

Strix flammea

Strix sauzieri

Struthio

Struthio

Struthio

Struthio

Struthio

Struthio

Struthio

Struthio

Struthio

Struthio camelus

Struthio camelus

Struthio molybdophanes

Sturnella militaris

Sula

Sula

Sula

Surnia passerina

Surnia ulula

Suthora bulmachus

Sylviella barakae

Sylviella denti

Synallaxis flavigularis

Syonium albitarse

Syrnium aluco

Syrrhaptes paradoxus

Syrrhaptes paradoxus

Syrrhaptes paradoxus

Tachyeres brachypterus

Tachyeres brachypterus

Tanagra cyanoptera

Tarsiger ruwenzori

Tarsiger ruwenzori

Telephonus erythropterus
Erxleben, 6: Plate 92

Parker, 9: Plate 55

Unsigned, 13: Plate 34

Wolf, J., 4: Flate 61

Owen, 9: Plate 35

Owen, 9: Plate 36

Owen, 9: Plate 37

Owen, 9: Plate 38

Owen, 9: Plate 39

Perker, 10: Plate 47

Grönvold, 19: Plate 19

Parker, 10: Plate 51

Parker, 10: Plate 47

Grönvold, 19: Plate 10

Keulemans, 9: Plate 89

Parker, 10: Plate 46

Grönvold, 16: Plate 26

Grönvold, 16: Plate 27

Grönvold, 16: Plate 28

Jennens, 4: Plate 57

Unsigned, 13: Plate 33

Erxleben, 3: Plate 18a

Erxleben, 3: Plate 19

Erxleben, 3: Plate 28

Erxleben, 3: Plate 29

Erxleben, 3: Plate 39

Erxleben, 3: Plate 43

Erxleben, 3: Plate 45

Erxleben, 3: Plate 53

Hamilton, 13: Plate 62

Grönvold, 15: Plate 45

Jury, 4: Plate 67a

Grönvold, 15: Plate 42

Parker, 10: Plate 49

Wesley, 10: Plate 56

Wesley, 10: Plate 59

Wesley, 10: Plate 60

Jennens, 4: Plate 56

Jennens, 4: Plate 56

Parker, 10: Plate 51

Grönvold, 19: Plate 19

Grönvold, 19: Plate 13

Parker, 9: Plate 59

Wolf, J., 4: Plate 60

Jennens, 4: Plate 57

Erxleben, 5: Plate 38

Erxleben, 5: Plate 41

Parker, W.K., 5: Plate 36

Owen, 9: Plate 36

Owen, 9: Plate 38

Parker, 10: Plate 46

Grönvold, 19: Plate 18

Grönvold, 19: Plate 19

Grönvold, 19: Plate 19 
Teraspiza rhodogaster

Terathopius ecaudatus

Terpsiphone suahelica

Thamnophilus doliatus

Thinocorus rumicivorus

Tinamus robustus

Tinamus robustus

Tinamus robustus

Tinamus robustus

Trichastoma celebense

Trichoglossus meyeri

Trochocercus bedfordi

Turnix rostratus

Uria grylle

Uria grylle

Urubitinga schistacea

Vanellus cristatus

Vireosylvia olivacea

Volvocivora caerulescens

Volvocivora morio

Xenocichla kikuyuensis

Zosterops atrifrons

Zosterops intermedia
Smit, 8: Plate 11

Unsigned, 21: Plate 20

Grönvold, 19: Plate 19

Parker, 9: Plate 57

Parker, 10: Plate 54

Erxleben, 5: Plate 39

Erxleben, 5: Plate 40

Erxleben, 5: Plate 41

Parker, W.K., 5: Plate 34

Parker, 9: Plate 58

Smit, 8: Plate 4

Grönvold, 19: Plate 18

Parker, 9: Plate 54

Smith, 5: Plate 51

Smith, 5: Plate 52

Wolf, J., 4: Plate 58

Parker, W.K., 5: Plate 37

Parker, 10: Plate 48

Smit, 9: Plate 30

Smit, 8: Plate 8

Grönvold, 19: Plate 19

Smit, 8: Plate 9

Smit, 8: Plate 9 
Acanthias blainvillii

Acanthias vulgaris

Acanthias vulgaris

Acestra gladius

Acipenser sturio

Acipenser sturio

Aelurichthys nuchalis

Ageneiosus childreni

Agonostoma microps

Agonostoma nasutum

Alepisaurus ferox

Alepisaurus ferox

Alestes rhodopleura

Ambassis barlovi

Amiurus meridionalis

Anacyrtus guatemalensis

Anacyrtus prognathus

Anarrhichas lupus

Anarrhinchas lupus

Ancistrus annectens

Ancistrus guentheri

Ancistrus oligospilus

Ancistrus platycephalus

Ancistrus setosus

Anguilla elphinstonei

Anisocentrus rubrostriatus

Antennarius leopardinus

Aplocheilichthys

rubrostigma

Arges brachycephalus

Arges chotae

Arges eigenmanni

Arges festae

Arges guentheri

Arges homodon

Arges marmoratus

Arges orientalis

Arges simonsii

Asprotilapia leptura

Auchenoglanis occidentalis

var. tanganicanus

Bagrus yarrelli

Barbus altianalis

Barbus kolus

Barbus mussullah

Barbus platyrhinus

Barbus serrifer

Barbus tropidolepis

Barilius moorii

Barilius tanganicae

Bathybates fasciatus

Bathybates ferox

Bathybates minor
Wesley, 10: Plate 77

Vincent, 14: Plate 10

Vincent, 14: Plate 13

Green, 14: Plate 41

Vincent, 14: Plate 10

Vincent, 14: Plate 14

Ford, 6: Plate 81

Unsigned, 2: Plate 66

Ford, 6: Plate 70

Ford, 6: Plate 70

Unsigned, 1: Plate 59

Young, 1: Plate 19

Green, 17: Plate 30

Unsigned, 2: Plate 60

Ford, 6: Plate 81

Ford, 6: Plate 82

Green, 14: Plate 8

Vincent, 14: Plate 14

Vincent, 14: Plate 12

Green, 17: Plate 11

Green, 17: Plate 12

Green, 17: Plate 12

Green, 17: Plate 12

Green, 17: Plate 12

Unsigned, 2: Plate 67

Green, 20: Plate 31

Ford, 6: Plate 69

Unsigned, 21: Plate 24

Green, 17: Plate 21

Green, 17: Plate 21

Green, 17: Plate 21

Green, 17: Plate 21

Green, 17: Plate 21

Green, 17: Plate 21

Green, 17: Plate 21

Green, 17: Plate 21

Green, 17: Plate 21

Green, 16: Plate 20

Green, 17: Plate 33

Unsigned, 2: Plate 65

Green, 16: Plate 13

Unsigned, 2: Plate 62

Unsigned, 2: Plate 61

Green, 16: Plate 12

Green, 16: Plate 14

Green, 16: Plate 13

Green, 16: Plate 14

Green, 16: Plate 14

Green, 16: Plate 17

Green, 15: Plate 4

Green, 17: Plate 38 
Belone graii

Callichthys pectoralis

Callorhynchus antiarcticus

Capoeta tanganicae

Centratherina crassispinosa

Centropristis macropoma

Ceratodus forsteri

Ceratodus fosteri

Cestracion philippi

Cetengraulis juruensis

Chaetodon humeralis

Chaetostomus anomalus

Chaetostomus bachi

Chaetostomus brevis

Chaetostomus gigas

Chaetostomus maculatus

Chaetostomus marcapatae

Chaetostomus marginatus

Chaetostomus microps

Chaetostomus thomsoni

Chalcinopsis dentex

Characodon lateralis

Chaunax pictus

Chela oweni

Chilatherina fasciata

Chiloscyllium ocellatum

Chimaera monstrosa

Chimaera monstrosa

Chimaera monstrosa

Chondrostoma kawrus

Chondrostoma mullya

Chondrostoma wattanah

Chrysichthys brachynema

Chrysichthys sianenna

Cirrhitichthys rivulatus

Citharichthys spilopterus

Clarias liocephalus

Clarias ngamensis

Clinus despicillatus

Clinus macrocephalus

Clupea harengus

Cobitis ruppelli

Conger conger

Conger conger

Conodon pacifici

Corvina chrysoleuca

Corvina vermicularis

Cottus gobio

Cremnobates monophthalmus

Cunningtonia longiventralis

Cyclopterus lumpus

Cyprinus abramioides

Cyprinus carpio
Unsigned, 2: Plate 63

Green, 14: Plate 4 Wesley, 10: Plate 79

Green, 16: Plate 12

Green, 20: Plate 31

Ford, 6: Plate 65

Lankester, 10: Plate 83

Parker, 14: Plate 29

Wesley, 10: Plate 76

Green, 14: Plate 41

Ford, 6: Plate 65

Green, 17: Plate 13

Green, 14: Plate 41

Green, 17: Plate 13

Green, 14: Plate 6

Green, 17: Plate 14

Green, 17: Plate 14

Green, 17: Plate 13

Green, 17: Plate 14

Green, 17: Plate 14

Ford, 6: Plate 82

Ford, 6: Plate 82

Woodall, 3: Plate 51

Unsigned, 2: Plate 63

Green, 20: Plate 31

Wesley, 10: Plate 76

Lankester, 10: Plate 84

Parker, T.J., 11: Plate 11

Vincent, 14: Plate 9

Unsigned, 2: Plate 62

Unsigned, 2: Plate 62

Unsigned, 2: Plate 62

Green, 16: Plate 15

Green, 17: Plate 32

Ford, 6: Plate 86

Jury, 6: Plate 80

Green, 15: Plate 7

Green, 18: Plate 38

Curtis, 3: Plate 6

Ford, 6: Plate 69

Vincent, 14: Plate 10

Unsigned, 2: Plate 64

Vincent, 14: Plate 10

Vincent, 14: Plate 14

West, 6: Plate 64

Ford, 6: Plate 67

Ford, 6: Plate 67

Vincent, 14: Plate 12

Ford, 6: Plate 69

Green, 17: Plate 41

Vincent, 14: Plate 13

Unsigned, 2: Plate 61

Unsigned, 21: Plate 24 
Dinotopterus cunningtoni

Echiodon drummondii

Ectodus descampsi

Ectodus longianalis

Ectodus longianalis

Ectodus melanogenys

Eretmodus cyanostictus

Esox lucius

Euanemus nigripinnis

Exocoetus callopterus

Farlowella gladiola

Farlowella gracilis

Fundulus guatemalensis

Fundulus labialis

Fundulus pachycephalus

Fundulus punctatus

Gadus aeglefinus

Gadus morrhua

Gambusia nicaraguensis

Geophagus duodecimspinosus

Gephyrochromis moorii

Ginglymostoma cirratum

Ginglymos toma cirratum

Girardinus pleurospilus

Gobius kurpah

Grammatotria lemairii

Gymnarchus niloticus

Haemulon margaritiferum

Haplochilus dovii

Haplochilus pumilus

Haplochilus tanganicanus

Haplotaxodon microlepis

Hemirhombus ovalis

Heros affinis

Heros angulifer

Heros aureus

Heros citrinellus

Heros dovii

Heros erythraeus

Heros godmanni

Heros guttulatus

Heros intermedius

Heros irregularis

Heros lobochilus

Heros longimanus

Heros managuensis

Heros margaritifer

Heros melanurus

Heros motaguensis

Heros multispinosus

Heros nicaraguensis

Heros nigrofasciatus

Heros salvini

Heros spilurus

Heros trimaculatus
Green, 17: Plate 31

Curtis, 2: Plate 38

Green, 15: Plate 19

Green, 15: Plate 19

Green, 16: Plate 19

Green, 15: Plate 19

Green, 15: Plate 3

Vincent, 14: Plate 11

Green, 14: Plate 4

Ford, 6: Plate 83

Green, 17: Plate 20

Green, 17: Plate 20

Ford, 6: Plate 84

Ford, 6: Plate 84

Ford, 6: Plate 84

Ford, 6: Plate 84

Vincent, 14: Plate 11

Vincent, 14: Plate 11

Ford, 6: Plate 82

Green, 14: Plate 4

Green, 16: Plate 20

Wesley, 10: Plate 75

Wesley, 10: Plate 76

Ford, 6: Plate 87

Unsigned, 2: Plate 61

Green, 15: Plate 18

Budgett, 16: Plate 11

Ford, 6: Plate 65

Ford, 6: Plate 82

Green, 17: Plate 32

Green, 15: Plate 6

Green, 17: Plate 38

Jury, 6: Plate 80

Jury, 6: Plate 79

Ford, 6: Plate 85

Ford, 6: Plate 73

West, 6: Plate 71

Ford, 6: Plate 73

Susini, 6: Plate 75

Ford, 6: Plate 74

Ford, 6: Plate 78

Ford, 6: Plate 78

Ford, 6: Plate 78

Susini, 6: Plate 75

Ford, 6: Plate 72

Ford, 6: Plate 77

West, 6: Plate 71

Ford, 6: Plate 72

Ford, 6: Plate 77

Ford, 6: Plate 74

Ford, 6: Plate 77

Ford, 6: Plate 74

Ford, 6: Plate 73

Ford, 6: Plate 73

Ford, 6: Plate 76 
Heros urophthalmus

Heterotis niloticus

Hippoglossoides

Iimandoides

Hippoglossus vulgaris

Histiophorus immaculatus

Hoplegnathus conwayii

Hyperopisus bebe

Hypophthalmus goongwaree

Hypophthalmus taakree

Hypoptopoma guentheri

Julidochromis ornatus

Lamna cornubica

Lamna cornubica

Lamprologus brevianalis

Lamprologus callipterus

Lamprologus calliurus

Lamprologus compressiceps

Lamprologus cunningtoni

Lamprologus elongatus

Lamprologus fasciatus

Lamprologus furcifer

Lamprologus lemairii

Lamprologus modestus

Lamprologus mondabu

Lamprologus moorii

Lamprologus multifasciatus

Lamprologus reticulatus

Lates angustifrons

Lates microlepis

Lates microlepis

Latris hecateia

Lepidolepris australis

Lepidosiren

Lepidosiren

Lepidosiren paradoxa

Lepidosiren paradoxa

Lepidosiren paradoxa

Leuciscus cephalus

Leuciscus rutilis

Leuciscus vulgaris

Lophius piscatorius

Loricaria apeltogaster

Loricaria jubata

Loricaria labialis

Loricaria laticeps

Loricaria latirostris

Loricaria macrops

Loricaria

microlepidogaster

Loricaria nigricauda

Loricaria parva

Loricaria punctata

Loricaria simillima

Marcusenius castelnaui
Ford, 6: Plate 72

Budgett, 16: Hlate 11

Vincent, 14: Plate 12

Vincent, 14: Plate 12

Ruppel1, 2: Plate 15

Mitchell, 3: Plate 7

Budgett, 16: Plate 11

Unsigned, 2: Plate 64

Unsigned, 2: Plate 64

Green, 17: Plate 15

Green, 15: Plate 2

Wesley, 10: Plate 74

Wesley, 10: Plate 75

Green, 17: Plate 36

Green, 17: Plate 36

Green, 17: Plate 35

Green, 15: Plate 1

Green, 17: Plate 36

Green, 15: Plate 1

Green, 15: Plate 1

Green, 15: Plate 2

Green, 15: Plate 18

Green, 15: Plate 1

Green, 17: Plate 36

Green, 15: Plate 1

Green, 17: Plate 35

Green, 17: Plate 35

Green, 17: Plate 35

Green, 15: Plate 1

Green, 17: Plate 35

Curtis, 3: Plate 6

Curtis, 3: Plate 8

Parker, 14: Plate 28

Parker, 14: Plate 29

Bayzand, 14: Plate 2

Smit, P.J., 14: Plate 37

Smit, P.J., 14: Plate 38

Vincent, 14: Plate 11

Vincent, 14: Plate 11

Vincent, 14: Plate 11

Vincent, 14: Plate 12

Green, 14: Plate 7

Green, 17: Plate 15

Green, 14: Plate 7

Green, 17: Plate 20

Green, 17: Plate 16

Green, 17: Plate 17

Green, 17: Plate 15

Green, 17: Plate 16

Green, 14: Plate 8

Green, 17: Plate 17

Green, 17: Plate 17

Green, 18: Plate 38 
Marcusenius tanganicanus

Mastacembelus armatus

Mastacembelus cunningtoni

Mastacembelus frenatus

Mastacembelus moorii

Mastacembelus taeniatus

Merluccius vulgaris

Mollienesia petenensis

Molva vulgaris

Mugil capito

Mullus barbatus

Mullus barbatus

Mustelus antarcticus Mystus badgee

Narcine tasmaniensis

Neetroplus nematopus

Nemadactylus concinnus

Neobola minuta

Notidanus cinereus

Ophicephalus

leucopunctatus

Orthagoriscus mola

Osmerus eperlanus

Ostracion auritus

Ostracion flavigaster

Ostracion ornatus

Ostracion spilogaster

Otocinclus vittatus

Oxydoras bachi

Oxydoras eigenmanni

Oxydoras elongatus

Oxydoras trachyparia

Oxydoras trimaculatus

Oxyloricaria frenata

Oxyloricaria guentheri

Oxyloricaria lyra

Oxyloricaria robusta

Pagellus centrodontus

Paratilapia angusticeps

Paratilapia aurita

Paratilapia calliura

Paratilapia dewindti

Paratilapia frederici

Paratilapia frontosa

Paratilapia furcifer

Paratilapia gibbiceps

Paratilapia leptosoma

Paratilapia longimanus

Paratilapia macrops

Paratilapia nigripinnis

Paratilapia pfefferi

Paratilapia smithii

Paratilapia stenosoma

Paratilapia thumbergi

Paratilapia ventralis
Green, 17: Plate 30

Unsigned, 2: Plate 60

Green, 17: Plate 41

Green, 16: Plate 20

Green, 15: Plate 7

Green, 16: Plate 20

Vincent, 14: Plate 11

Ford, 6: Plate 86

Vincent, 14: Plate 11

Vincent, 14: Plate 13

Vincent, 14: Plate 12

Vincent, 14: Plate 14

Wesley, 10: Plate 74

Unsigned, 2: Plate 67

Mitchel1, 3: Plate 11

Ford, 6: Plate 74

Curtis, 3: Plate 4

Green, 17: Plate 32

Wesley, 10: Plate 75

Unsigned, 2: Plate 60

Vincent, 14: Plate 10

Vincent, 14: Plate 11

Mitchel1, 3: Plate 9

Mitchel1, 3: Plate 11

Hawkins, 3: Plate 10

Hawkins, 3: Plate 10

Green, 17: Plate 15

Green, 14: Plate 40

Green, 14: Plate 4

Green, 14: Plate 40

Green, 14: Plate 40

Green, 14: Plate 40

Green, 17: Plate 18

Green, 17: Plate 18

Green, 17: Plate 19

Green, 17: Plate 19

Vincent, 14: Plate 12

Green, 18: Plate 42

Green, 16: Plate 19

Green, 16: Plate 19

Green, 15: Plate 18

Green, 18: Plate 39

Green, 17: Plate 37

Green, 15: Plate 4

Green, 18: Plate 43

Green, 15: Plate 3

Green, 18: Plate 40

Green, 15: Plate 3

Green, 16: Plate 19

Green, 15: Plate 3

Green, 18: Plate 39

Green, 16: Plate 17

Green, 18: Plate 41

Green, 15: Plate 3 
Paratilapia vittata

Pellonula miodon

Pelmatochromis auritus

Pelmatochromis melanos tigma

Pelmatochromis pleurospilus

Pelmatochromis polylepis

Pelmatochromis rhodostigma

Perca fluviatilis

Perissodus microlepis

Petenia splendida

Petrochromis polyodon

Phractocephalus gogra

Phractocephalus itchkeea

Phractocephalus kuturnee

Phyllonemus typus

Pimelodus seengtee

Plagioscion ternetzi

Platyglossus dispilus

Platystoma juruense

Platystoma seenghala

Plecostomus borellii

Plecostomus cordovae

Plecostomus festae

Plecostomus garmani

Plecostomus latirostris

Plecostomus ternetzi

Plecostomus wuchereri

Plectropoma afrum

Pleuronectes flesus

Pleuronectes limanda

Pleuronectes limanda

Pleuronectes platessa

Poecilia elongata

Poecilia petenensis

Polyodon folium

Polypterus

Polypterus

Polypterus

Polypterus bichir

Polypterus lapradei

Polypterus lapradei

Polypterus lapradei

Polypterus senegalus

Polypterus senegalus

Polypterus senegalus

Pristiophorus japonicus

Pristiophorus japonicus

Pristipoma leuciscus

Pristipoma macracanthum

Pristis cuspidata

Pristiurus

Pristiurus

Protopterus annectens
Green, 16: Plate 18

Green, 17: Plate 30

Green, 17: Plate 39

Green, 17: Plate 39

Green, 17: Plate 39

Green, 17: Plate 37

Green, 17: Plate 39

Vincent, 14: Plate 12

Green, 15: Plate 6

Jury, 6: Plate 79

Green, 15: Plate 6

Unsigned, 2: Plate 66

Unsigned, 2: Plate 67

Unsigned, 2: Plate 65

Green, 17: Plate 32

Unsigned, 2: Plate 66

Green, 14: Plate 3

Ford, 6: Plate 74

Geeen, 14: Plate 39

Unsigned, 2: Plate 65

Green, 17: Plate 9

Green, 17: Plate 9

Green, 17: Plate 9

Green, 17: Plate 10

Green, 17: Plate 11

Green, 14: Plate 5

Green, 17: Plate 10

Ford, 6: Plate 67

Vincent, 14: Plate 11

Vincent, 14: Plate 11

Vincent, 14: Plate 14

Vincent, 14: Plate 11

Ford, 6: Plate 85

Ford, 6: Plate 85

Wesley, 10: Plate 78

Budgett, 16: Plate 33

Budgett, 16: Plate 34

Budgett, 16: Plate 35

Wesley, 10: Plate 79

Budgett, 16: Plate 11

Wilson, 15: Plate 50

Wilson, 15: Plate 52

Wilson, 15: Plate 50

Wilson, 15: Plate 51

Wilson, 15: Plate 52

Wesley, 10: Plate 77

Wesley, 10: Plate 78

Ford, 6: Plate 66

West, 6: Plate 64

Wesley, 10: Plate 78

Parker, 10: Plate 35

Parker, 10: Plate 40

Bayzand, 14: Plate 2 
Protopterus annectens

Protopterus annectens

Protopterus annectens

Pseudojulis notospilus

Raia

Raia batis

Raia clavata

Raia clavata

Raia maculata

Raia maculata

Raia maculata

Raia maculata

Raja batis

Raja clavata

Raja maculata

Regalecus argenteus

Regalecus argenteus

Regalecus argenteus

Regalecus argenteus

Regalecus argenteus

Rhadinocentris ornatus

Rhombosoma novae-guineae

Rhombus laevis

Rhynchobatus djeddensis

Rohtee ogilbii

Rohtee vigorsii

Salmo salar

Salmo salar

Sarcodaces odoë

Schedophilus medusophagus

Schilbe boalis

Scomber scomber

Scyllium canicula

Scyllium canicula

Scyllium canicula

Scyllium canicula

Scyllium canicula

Scyllium canicula

Scyllium canicula

Scyllium canicula

Scyllium canicula

Scyllium canicula

Scyllium canicula

Scyllium catulus

Serranus rasor

Solea vulgaris

Spinax niger

Squatina angelus

Sternarchus tamandua

Syngnathus argus

Synodontis granulosus

Synodontis melanostictus

Synodontis multipunctatus

Telmatochromis temporalis

Telmatochromis vittatus
Budgett, 16: Plate 10

Budgett, 16: Plate 11

Lankester, 10: Plate 84

Ford, 6: Plate 66

Parker, T.J., 11: Plate 10

Parker, T.J., 11: Plate 10

Parker, 10: Plate 41

Parker, 10: Plate 42

Parker, 10: Plate 39

Parker, 10: Plate 40

Parker, T.J., 11: Plate 10

Wesley, 10: Plate 78

Vincent, 14: Plate 10

Vincent, 14: Plate 13

Vincent, 14: Plate 10

Parker, 12: Plate 2

Parker, 12: Plate 3

Parker, 12: Plate 4

Parker, 12: Plate 5

Parker, 12: Plate 6

Green, 20: Plate 31

Green, 20: Plate 31

Vincent, 14: P1ate 12

Wesley, 10: Plate 78

Unsigned, 2: Plate 63

Unsigned, 2: Plate 63

Unsigned, 21: Plate 24

Vincent, 14: Plate 11

Budgett, 16: Plate 11

Mintern, 11: Plate 47

Unsigned, 2: Plate 64

Vincent, 14: Plate 12

Parker, 10: Plate 34

Parker, 10: Plate 35

Parker, 10: Plate 36

Parker, 10: Plate 37

Parker, 10: Plate 38

Parker, 10: Plate 39

Parker, 10: Plate 42

Parker, T.J., 11: Plate 11

Vincent, 14: Plate 13

Vincent, 14: Plate 9

Wesley, 10: Plate 75

Vincent, 14: Plate 9

Curtis, 3: Plate 4

Vincent, 14: Plate 12

Wesley, 10: Plate 77

Wesley, 10: Plate 77

Green, 14: Plate 42

Mitchel1, 3: Plate 7

Green, 16: Plate 16

Green, 17: Plate 34

Greem. 15: Plate 8

Green, 15: Plate 2

Green, 15: Plate 2 
Tetragonopterus

$$
\text { rubropictus }
$$

Tetragonopterus ternetzi

Tetragonopterus ulreyi

Thalassophryne maculosa

Thalassophryne reticulata

Tilapia boops

Tilapia dardennii

Tilapia grandoculis

Tilapia labiata

Tilapia latifrons

Tilapia microlepis

Tilapia pleurotaenia

Tilapia rubropunctata

Tilapia trematocephala

Tilapia woosnami

Trachynotus fasciatus

Trematocara marginatum

Trematocara nigrifrons

Trematocara unimaculatum

Trigla lyra

Trigla pini

Trigla polyommata

Trigla vanessa

Tropheus moorii

Trygonorhina fasciata

Umbrina elongata

Upeneus tetraspilus

Varicorhinus bobree

Xenocara chagresi

Xenocara latifrons

Xenocara montana

Xenocara occidentalis

Xenotilapia ornatipinnis

Xenotilapia sima

Xiphophorus helleri

Zeus faber

Zygaena malleus

Zygaena malleus

Unsigned, 21: Plate 24
Green, 14: Plate 8
Green, 14: Plate 8
West, 6: Plate 68
West, 6: Plate 68
Green, 16: Plate 19
Green, 15: Plate 20
Green, 15: Plate 19
Green, 15: Plate 5
Green, 17: Plate 40
Green, 15: Plate 20
Green, 16: Plate 18
Green, 15: Plate 20
Green, 16: Plate 19
Green, 18: Plate 43
Ford, 6: Plate 69
Green, 15: Plate 19
Green, 17: Plate 41
Green, 16: Plate 18
Vincent, 14: Plate 12
Vincent, 14: Plate 12
Curtis, 3: Plate 5
Curtis, 3: Plate 5
Green, 15: Plate 5
Wesley, 10: Plate 78
West, 6: Plate 64
Ford, 6: Plate 66
Unsigned, 2: Plate 61
Green, 17: Plate 14
Green, 17: Plate 15
Green, 17: Plate 14
Green, 17: Plate 14
Green, 16: Plate 18
Green, 15: Plate 19
Ford, 6: Plate 87
Vincent, 14: Plate 12
Parker, T.J. $11:$ Plate 11
Wesley, 10: Plate 74


Adeonellopsis incisa

Adeonellops is wetherelli

Adeonellops is wetherelli

Bairdia oviformis

Biselenaria offa

Bos

Canis vulpes

Cervus belgrandi

Cervus dama

Cervus elephus

Cervus elephus var. barbarus

Cervus elephus var. barbarus?

Conescharellina clithridiata

Cribrilina vinei

Cygnus falconeri

Cygnus musicus?

Cygnus olor

Cythere acuticosta

Cythere belgica

Cythere cicatricosa

Cythere cornuta

Cythere cribrosa?

Cythere dawsoni?

Cythere ellipsoidea

Cythere jonesii

Cythere jurinei

Cythere latimarginata

Cythere limicola

Cythere macropora

Cythere macropora

Cythere mucronata

Cythere oedichilus

Cythere petrosa

Cythere plicata

Cythere plicatula

Cythere polytrema

Cythere scabropapulosa

Cythere subcoronata

Cythere tarentina

Cythere trapezia

Cythere wetherellii

Cythere woodiana

Cytherella elliptica

Cytherella nodosa

Cytherella parallela

Cytheridea cypridioides

Cytheridea mulleri

Cytheridea papillosa var.

Cytheridea pinguis
Woodward, EC, 13: Plate 30

Woodward, EC, 13: Plate 30 Woodward, EC, 13: Plate 31 Brady, 10: Plate 63

Woodward, EC, 13: Plate 30 B., E.M., 10: Plate 18

B., E.M., 10: Plate 3

Wilson, 15: Plate 21

B., E.M., 10: Plate 19

B., E.M., 10: Plate 21

B., E.M., 10: Plate 21

Dinkel, 10: Plate 20

Woodward, EC, 13: Plate 31

Woodward, EC, 13: Plate 30

Erxleben, 6: Plate 30

Erxleben, 6: Plate 30

Erxleben, 6: Plate 30

Brady, 10: Plate 66

Brady, 10: Plate 65

Brady, 10: Plate 64

Brady, 10: Plate 66

Brady, 10: Plate 64

Brady, 10: Plate 66

Brady, 10: Plate 65

Brady, 10: Plate 67

Brady, 10: Plate 65

Brady, 10: Plate 64

Brady, 10: Plate 64

Brady, 10: Plate 66

Brady, 10: Plate 67

Brady, 10: Plate 67

Brady, 10: Plate 64

Brady, 10: Plate 64

Brady, 10: Plate 65

Brady, 10: Plate 64

Brady, 10: Plate 66

Brady, 10: Plate 66

Brady, 10: Plate 67

Brady, 10: Plate 63

Brady, 10: Plate 66

Brady, 10: Plate 64

Brady, 10: Plate 65

Brady, 10: Plate 62

Brady, 10: Plate 62

Brady, 10: Plate 62

Brady, 10: Plate 69

Brady, 10: Plate 62

Brady, 10: Plate 62

Brady, 10: Plate 62 
Cytherideis(?)

lithodomoides

Cytherideis recta

Cytheropteron gradatum

Cytheropteron intermedium

Cytheropteron latissimum

Cytheropteron pipistrella

Cytherura broeckiana

Didosaurus mauritianus

Elephas melitensis

Elephas melitensis

Elephas melitensis

Elephas melitensis

Elephas melitensis

Elephas melitensis

Elephas melitensis

Elephas melitensis

Elephas melitensis

Elephas melitensis

Elephas melitensis

Elephas melitensis

Elephas melitensis

Elephas melitensis

Elephas melitensis

Elephas melitensis

Elephas melitensis

Elephas melitensis

Elephas mnaidriensis

Elephas mnaidriensis

Elephas mnaidriensis

Elephas mnaidriensis

Elephas mnaidriensis

Elephas mnaidriensis

Elephas mnaidriensis

Elephas mnaidriensis

Elephas mnaidriensis

Elephas mnaidriens is

Elephas mnaidriensis

Elephas mnaidriensis

Elephas mnaidriensis

Elephas mnaidriens is

Elephas mnaidriensis

Elephas mnaidriensis

Elephas mnaidriensis

Entalophora tergemina

Equus caballus

Equus caballus

Equus caballus

Equus caballus

Felidae caligata

Felidae pardina

Felidae pardus

Heteropora glandiformis

Hippopotamus (?)

Hornera farehamens is
Brady, 10: Plate 63

Brady, 10: Plate 63

Brady, 10: Plate 69

Brady, 10: Plate 69

Brady, 10: Plate 69

Brady, 10: Plate 69

Brady, 10: Plate 69

Unsigned, 13: Plate 44

Griesbach, 9: Plate 1

Griesbach, 9: Plate 11

Griesbach, 9: Plate 12

Griesbach, 9: Plate 13

Griesbach, 9: Plate 14

Griesbach, 9: Plate 15

Griesbach, 9: Plate 2

Griesbach, 9: Plate 21

Griesbach, 9: Plate 4

Griesbach, 9: Plate 5

Griesbach, 9: Plate 9

Wesley, 9: Plate 10

Wesley, 9: Plate 16

Wesley, 9: Plate 17

Wesley, 9: Plate 18

Wesley, 9: Plate 19

Wesley, 9: Plate 20

Wesley, 9: Plate 6

Griesbach, 9: Plate 1

Griesbach, 9: Plate 11

Griesbach, 9: Plate 14

Griesbach, 9: Plate 15

Griesbach, 9: Plate 2

Griesbach, 9: Plate 21

Griesbach, 9: Plate 3

Griesbach, 9: Plate 4

Griesbach, 9: Plate 8

Wesley, 9: Plate 10

Wesley, 9: Plate 16

Wesley, 9: Plate 17

Wesley, 9: Plate 18

Wesley, 9: Plate 19

Wesley, 9: Plate 20

Wesley, 9: Plate 6

Wesley, 9: Plate 7

Woodward, EC, 13: Plate 32

B., E.M., 10: Plate 18

B., E.M., 10: Plate 7

B., E.M., 10: Plate 8

B., E.M., 10: Plate 9

B., E.M., 10: Plate 3

B., E.M., 10: Plate 3

B., E.M., 10: Plate 3

Woodward, EC, 13: Plate 32

Griesbach, 9: Plate 11

Woodward, EC, 13: Plate 32 
Hyena crocuta
Hyena crocuta
Ibex
Ibex
Ibex
Ibex
Ibex
Ibex
Idmonea bialternata
Idmonea coronopus
Idmonea giebeli
Idmonea seriatopora
Idmonea seriatopora
Laricsaurus balsami
Lepralia lonsdalei
Lichenopora

Loxoconcha bitruncata Loxoconcha grateloupiana

Loxoconcha latissima Loxoconcha variolata Lunulites transiens Lunulites transiens Meles taxus

Membranipora buski

Membranipora crassomuralis

Membranipora disjuncta

Membranipora eocena

Membranipora tenuimuralis

Membranipora virguliformis

Meniscopora bigibbera

Micropora cribiformis

Mucronella angustoaecium

Myoxus melitensis

Notamia wetherelli

Onychocella magnoaperta

Orbitulipora petiolus

Palorchestes crassus

Paracypris polita

Paradoxostoma ensiforme

Phororhacos inflatus

Phororhacos inflatus

Phororhacos inflatus

Phororhacos inflatus

Pontocypris faba

Pontocypris propinqua

Rhinoceros hemitoechus

Rhinoceros hemitoechus

Rhinoceros hemitoechus

Rhinoceros hemitoechus

Rhinoceros hemitoechus

Rhinoceros hemitoechus

Rhinoceros hemitoechus

Rhinoceros hemitoechus

Rhinoceros hemitoechus

Schizoporella magnoaperta
Dinkel, 10: Plate 1

Dinkel, 10: Plate 2

B., E.M., 10: Plate 23

B., E.M., 10: Plate 24

B., E.M., 10: Plate 25

B., E.M., 10: Plate 26

Dinkel, 10: Plate 20

Dinkel, 10: Plate 22

Woodward, EC, 13: Plate 32

Woodward, EC, 13: Plate 32

Woodward, EC, 13: Plate 32

Woodward, EC, 13: Plate 32

Woodward, EC, 13: Plate 32

Woodward, AM, 14: Plate 1

Woodward, EC, 13: Plate 31

Woodward, EC, 13: Plate 32

Brady, 10: Plate 68

Brady, 10: Plate 68

Brady, 10: Plate 68

Brady, 10: Plate 68

Woodward, EC, 13: Plate 29

Woodward, EC, 13: Plate 30

B., E.M., 10: Plate 3

Woodward, EC, 13: Plate 29

Woodward, EC, 13: Plate 29

Woodward, EC, 13: Plate 29

Woodward, EC, 13: Plate 29

Woodward, EC, 13: Plate 29

Woodward, EC, 13: Plate 29

Woodward, EC, 13: Plate 31

Woodward, EC, 13: Plate 30

Woodward, EC, 13: Plate 31

Adams, 6: Plate 54

Woodward, EC, 13: Plate 29

Woodward, EC, 13: Plate 30

Woodward, EC, 13: Plate 31

Smit, 11: Plate 2

Brady, 10: Plate 63

Brady, 10: Plate 64

Green, 15: Plate 14

Green, 15: Plate 15

Green, 15: Plate 16

Green, 15: Plate 17

Brady, 10: Plate 63

Brady, 10: Plate 63

B., E.M., 10: Plate 10

B., E.M., 10: Plate 11

B., E.M., 10: Plate 12

B., E.M., 10: Plate 13

B., E.M., 10: Plate 14

B., E.M., 10: Plate 15

B., E.M., 10: Plate 16

B., E.M., 10: Plate 17

B., E.M., 10: Plate 18

Woodward, EC, 13: Plate 30 
Schizoporella magnoincisa Smittia tubularis

Teichopora clavata

Testudo atlas

Testudo grandidieri

Testudo grandidieri

Testudo grandidieri

Testudo Indica?

Testudo inepta

Testudo sauzieri

Testudo sumeirei

Testudo sumeirei

Testudo sumeirei

Testudo triserrata

Testudo triserrata

Trogontherium cuvieri

Umbonula bartonense

Umbonula calcariformis

Ursus arctos

Ursus arctos

Ursus arctos

Xestoleberis depressa
Woodward, EC, 13: Plate 30 Woodward, EC, 13: Plate 32 Woodward, EC, 13: Plate 31 Unsigned, 13: Plate 44

Woodward, EC, 13: Plate 39 Woodward, EC, 13: Plate 40 Woodward, EC, 13: Plate 41 Unsigned, 13: Plate 42 Unsigned, 13: Plate 43 Unsigned, 13: Plate 42 Unsigned, 13: Plate 42 Unsigned, 13: Plate 43 Unsigned, 13: Plate 44 Unsigned, 13: Plate 42 Unsigned, 13: Plate 43 Berjeau, 13: Plate 19 Woodward, EC, 13: Plate 31 Woodward, EC, 13: Plate 31 B., E.M., 10: Plate 5 Dinkel, 10: Plate 4 Dinkel, 10: Plate 6 Brady, 10: Plate 66 
Acanthomia insignis

Acisoma panorpoides(?)

Aethriamanta brevipennis

Agrionoptera 4-notata

Anatya anomala

Anatya anomala

Anoplocnemis signata Antidythemis trameiformis

Apis dorsata

Apis floralis

Asarcina amaena

Asarcina punctifrons

Aspongopus alternatus

Athalia centifoliae

Aufidus balteatus

Awemba typica

Belonia foliata

Bhooria klossi

Bombus atrocinctus

Brachydiplax indica

Cannacria batesii

Cannacria batesil

Carbula bicolor

Carbula fuscata

Caura leggei

Celithemis fasciata

Cenaeus semiflavus

Chrysopilus binoculatus

Deielia fasciata

Dejeania wollastonii

Dexia inappendiculata

Dindymoides abdominalis

Dindymus croesus

Dissoptera pollinosa

Dysdercus pretiosus

Emanadia sp.?

Erythemis peruviana

Euacanthus papuensis

Eumenes conica

Eumenes edwardsii

Eumenes esuriens

Eumenes mainpuriensis

Folengus papuensis

Fylgia amazonica

Fylla exigua

Galleria mellolella

Grapaldus corticinus

Harpactor ornatellus

Holopterna affinis

Holopterna wollastoni

Holotania axilena

Hydrobasileus vittatus

Icaria variegata
Knight, 19: Plate 2

Mintern, 12: Plate 56

Mintern, 12: Plate 53

Mintern, 12: Plate 56

Mintern, 12: Plate 53

Mintern, 12: Plate 57

Knight, 19: Plate 2

Mintern, 12: Plate 51

Horne, 7: Plate 22

Horne, 7: Plate 22

Terzi, 19: Plate 3

Terzi, 19: Plate 3

Knight, 19: Plate 2

Westwood, 2: Plate 14

Knight, 20: Plate 34

Knight, 19: Plate 2

Mintern, 12: Plate 54

Knight, 20: Plate 34

Horne, 7: Plate 21

Mintern, 12: Plate 54

Mintern, 12: Plate 53

Mintern, 12: Plate 57

Knight, 19: Plate 2

Knight, 19: Plate 2

Knight, 19: Plate 2

Mintern, 12: Plate 52

Knight, 19: Plate 2

Knight, 20: Plate 38

Mintern, 12: Plate 53

Terzi, 19: Plate 3

Terzi, 19: Plate 3

Knight, 20: Plate 34

Knight, 20: Plate 34

Knight, 20: Plate 38

Knight, 19: Plate 2

Horne, 7: Plate 22

Mintern, 12: Plate 55

Knight, 20: Plate 34

Horne, 7: Plate 20

Horne, 7: Plate 20

Horne, 7: Plate 20

Horne, 7: Plate 20

Knight, 20: Plate 34

Mintern, 12: Plate 51

Mintern, 12: Plate 52

Horne, 7: Plate 22

Knight, 20: Plate 34

Knight, 19: Plate 2

Knight, 19: Plate 2

Knight, 19: Plate 2

Mintern, 12: Plate 57

Mintern, 12: Plate 51

Horne, 7: Plate 20 
Leptataspis elegantula

Lepthemis vesiculosa

Lepyronia aethiops

Libellula depressa

Lyriothemis braueri

Macrothemis hemichlora

Macrothemis hemichlora

Maira wollastoni

Megachile disjuncta

Megachile fasciculata

Megachile lanata

Megaspis bulligera

Megastethodon modestus

Mesothemis simplicicollis

Miathyria pusilla

Microthemis duivenbodi

Misagria parana

Misagria parana

Mygdonia montana

Nannodythemis australis

Nannophya pygmaea

Nesoxenia cingulata

Neurothemis affinis

Neurothemis disparilis

Neurothemis fulvia

Nycteribia biarticulata

Nycteribia blainvillii

Nycteribia dufourii

Nycteribia hopei

Nycteribia jenynsii

Nycteribia latreillii

Nycteribia roylii

Nycteribia sykesil

Odynerus punctum

Orchithemis pulcherrima

Ortaloptera cleitamina

Orthemis ferruginea

Orthemis flavopicta

Orthemis flavopicta

Orthetrum caerulescens

Orthetrum sabina

Palpopleura jucunda

Parapison rufipes

Pelopoeus bengalensis

Pelopoeus bilineatus

Pelopoeus madraspatanus

Perithemis bella

Perithemis intensa

Phytalmia? wollastoni

Pisonitus rugosus

Plectropoda bicolor

Plesiocyptera divisa

Proagonistes praedo

Promachus noscibilis

Protorthemis celebensis
Knight, 20: Plate 34

Mintern, 12: Plate 57

Knight, 19: Plate 2

Mintern, 12: Plate 55

Mintern, 12: Plate 53

Mintern, 12: Plate 54

Mintern, 12: Plate 57

Knight, 20: Plate 38

Horne, 7: Plate 19

Horne, 7: Plate 19

Horne, 7: Plate 19

Terzi, 19: Plate 3

Knight, 20: Plate 34

Mintern, 12: Plate 57

Mintern, 12: Plate 52

Mintern, 12: Plate 56

Mintern, 12: Plate 52

Mintern, 12: Plate 57

Knight, 19: Plate 2

Mintern, 12: Plate 52

Mintern, 12: Plate 56

Mintern, 12: Plate 53

Mintern, 12: Plate 54

Mintern, 12: Plate 54

Mintern, 12: Plate 55

Westwood, 1: Plate 36

Westwood, 1: Plate 36

Westwood, 1: Plate 36

Westwood, 1: Plate 36

Westwood, 1: Plate 36

Westwood, 1: Plate 36

Westwood, 1: Plate 36

Westwood, 1: Plate 36

Horne, 7: Plate 20

Mintern, 12: Plate 56

Knight, 20: Plate 38

Mintern, 12: Plate 57

Mintern, 12: Plate 54

Mintern, 12: Plate 57

Mintern, 12: Plate 55

Mintern, 12: Plate 55

Mintern, 12: Plate 56

Horne, 7: Plate 21

Horne, 7: Plate 21

Horne, 7: Plate 21

Horne, 7: Plate 21

Mintern, 12: Plate 51

Mintern, 12: Plate 51

Knight, 20: Plate 38

Horne, 7: Plate 21

Knight, 19: Plate 2

Knight, 20: Plate 38

Terzi, 19: Plate 3

Knight, 20: Plate 38

Mintern, 12: Plate 54 
Protorthemis celebensis

Pseudoleon superbus

Pseudomacromia torrida

Pseudothemis zonata

Pterochilus pulchellus

Ptilocera violacea

Ptyelus niveus

Ranatra fuscoannulata

Raphismia bispina

Rhodopygia cardinalis

Rhynchium carnaticum

Rhynchium nitidulum

Rhyothemis apicalis

Rhyothemis cuprina

Rioxa flava

Sarcophaga inaequalis

Sarcophaga notatipennis

Senaspis aesacus

Senaspis elliotii

Sericophoromyia claripilosa

Sympetrum pallidinervis

Syrphus adigatus

Tabanus ruwenzorii

Tetrathemis flavescens

Tetrathemis hyalina

Thermochoria equivocata

Tipula de-meijerei

Tramea darwinii

Trithemis(?) attenuata

Trypoxylon rejector

Tyriobapta torrida

Untamo apicalis

Vespa flaviceps

Vespa structor

Vespa vivax

Xylocopa chloroptera

Zyxomma petiolatum
Mintern, 12: Plate 57

Mintern, 12: Plate 53

Mintern, 12: Plate 52

Mintern, 12: Plate 52

Horne, 7: Plate 21

Knight, 20: Plate 38

Knight, 19: Plate 2

Knight, 19: Plate 2

Mintern, 12: Plate 56

Mintern, 12: Plate 52

Horne, 7: Plate 20

Horne, 7: Plate 20

Mintern, 12: Plate 51

Mintern, 12: Plate 51

Knight, 20: Plate 38

Terzi, 19: Plate 3

Terzi, 19: Plate 3

Terzi, 19: Plate 3

Terzi, 19: Plate 3

Terzi, 19: Plate 3

Mintern, 12: Plate 55

Terzi, 19: Plate 3

Terzi, 19: Plate 3

Mintern, 12: Plate 52

Mintern, 12: Plate 56

Mintern, 12: Plate 52

Knight, 20: Plate 38

Mintern, 12: Plate 51

Mintern, 12: Plate 53

Horne, 7: Plate 21

Mintern, 12: Plate 54

Mintern, 12: Plate 53

Horne, 7: Plate 21

Horne, 7: Plate 21

Horne, 7: Plate 21

Horne, 7: Plate 22

Mintern, 12: Plate 57 
Adoretus flavovittatus Agrilus continuatus Alaus trifasciatus Alcides parentheticus Allagogus brunneus Amphitmetus foveipennis Amphitmetus leggei Amphitmetus planicollis Ancistrosoma klugii Anomiopsis dioscorides Anomiopsis sterquilinus Anthicus cyaneus Aploa picta Apotmetus montanus Arachnopus biplagiatus Arachnopus lanceolatus Arachnopus planatus Aulamorphus variabilis Blosyrus seminitidus Calostega purpuripennis Cecidoses eremita Ceroplesis reticulata Chiroscelis bifenestrella Chiroscelis digitata Chiroscelis passaloides Chlaenius sykesii

Clytus (Perissus) wollastoni

Colobodes cavisquamis Coptocercus unifasciatus Coptopterus cretifer Coptorhina africana Cornuscoparia wollastoni Diacantha nigronotata Diacantha nigronotata var. Dirphya delecta

Disodontogenus wollastoni Dysopirhinus costatus Ectatocyba verrucosa Entebbia bipunctata Epilachna gemmifera Epilachna lucifera Epilachna nympha Epilachna serva Glenea montivaga Glycyphana (Gametis) tigrina

Heterochthes andamanensis Heterochthes brachypterus Heteronyx colossus Horia nitida

Ichthyosoma (Elais) albomaculatum
Knight, 19: Plate 7 Knight, 19: Plate 7 Knight, 19: Plate 6 Knight, 20: Plate 39 Knight, 19: Plate 7 Knight, 19: Plate 7 Knight, 19: Plate 7 Knight, 19: Plate 7 Curtis, 1: Plate 40 Westwood, 2: Plate 29 Westwood, 2: Plate 29 Westwood, 1: Plate 14 Westwood, 1: Plate 13 Knight, 19: Plate 7 Knight, 20: Plate 39 Knight, 20: Plate 39 Knight, 20: Plate 39 Knight, 19: Plate 7 Knight, 19: Flate 7 Westwood, 3: Plate 15 Curtis, 1: Plate 40 Knight, 19: Plate 6 Westwood, 3: Plate 14 Westwood, 3: Plate 14 Westwood, 3: Plate 14 Westwood, 1: Plate 13

Knight, 19: Plate 6 Knight, 20: Plate 39 Unsigned, 3: Plate 12 Unsigned, 3: Plate 12 Westwood, 1: Plate 14 Knight, 20: Plate 39 Knight, 19: Plate 7 Knight, 19: Plate 7 Knight, 19: Plate 6 Knight, 19: Plate 7 Knight, 20: Plate 39 Knight, 20: Plate 39 Knight, 19: Plate 6 Knight, 19: Plate 7 Knight, 19: Plate 7 Knight, 19: Plate 7 Knight, 19: Plate 7 Knight, 19: Plate 6

Knight, 19: Plate 7 Wilson, 11: Plate 84 Wilson, 11: Plate 84 Knight, 20: Plate 39 Knight, 19: Plate 6

Knight, 20: Plate 39 
Isacantha rhinotioides

Lagria rugipennis

Lamia crux nigra

Lamia roylii

Languria cyanea

Lophocheirus wollastoni

Lucanus aeratus

Lucanus downesii

Lycus (Acantholycus)

modestus

Lycus (Lycostomus)

runsoriensis

Lycus vittatus

Lyprops chrysophthalmus

Macrolopha quadrimaculata

Megacantha tenebrosa

Melyris monticola

Neolucanus castanopterus

Neolucanus championi

Neolucanus cingulatus

Neolucanus lama

Neolucanus lama var. angulatus

Neolucanus lansbergii

Neolucanus laticollis

Neolucanus marginatus

Neolucanus pallescens

Neolucanus parryi

Neolucanus saundersi

Neolucanus sinicus

Neolucanus swinhoii

Nesioticus flavo-pictus

Nothophysis johnstoni

Nyctobates brevicornis

Nyctobates confuscus

var angustior

Nyctobates confusus

Nyctobates hypocrita

Nyctobates moerens

Nyctobates punctatus

Nyctobates rotundicollis

Nyctobates transversalis

Odontolabis aeratus

Odontolabis alces

Odontolabis bellicosus

Odontolabis brookeanus

Odontolabis burmeisteri

Odontolabis camelus

Odontolabis carinatus

Odontolabis carinatus var. cingalensis

Odontolabis castelnaudi

Odontolabis celebensis

Odontolabis cuvera

Odontolabis dalmani
Westwood, 1: Plate 14 Knight, 19: Plate 6 Westwood, 1: Plate 15 Westwood, 1: Plate 15 Westwood, 1: Plate 13 Knight, 20: Plate 39 Westwood, 1: Plate 14 Westwood, 1: Plate 13

Knight, 19: Plate 6

Knight, 19: Plate 6 Knight, 19: Plate 6 Westwood, 1: Plate 14 Knight, 19: Plate 7

Westwood, 3: Plate 15 Knight, 19: Plate 6 Wilson, 11: Plate 84 Wilson, 11: Plate 85 Wilson, 11: Plate 85 Wilson, 11: Plate 85

Wilson, 11: Plate 85 Wilson, 11: Plate 84 Wilson, 11: Plate 84 Wilson, 11: Plate 85 Wilson, 11: Plate 85 Wilson, 11: Plate 85 Wilson, 11: Plate 85 Wilson, 11: Plate 85 Wilson, 11: Plate 84 Westwood, 3: Plate 15 Knight, 19: Plate 6 Westwood, 3: Plate 15

Westwood, 3: Plate 15 Westwood, 3: Plate 15 Westwood, 3: Plate 15 Westwood, 3: Plate 15 Westwood, 3: Plate 15 Westwood, 3: Plate 15 Westwood, 3: Plate 15 Wilson, 11: Plate 97 Wilson, 11: Plate 89 Wilson, 11: Plate 88 Wilson, 11: Plate 95 Wilson, 11: Plate 92 Wilson, 11: Plate 96 Wilson, 11: Plate 97

Wilson, 11: Plate 97 Wilson, 11: Plate 95 Wilson, 11: Plate 88 Wilson, 11: Plate 91 Wilson, 11: Plate 87 
Odontolabis delesserti

Odontolabis duivenbodii

Odontolabis fratellus

Odontolabis gazella

Odontolabis gazella

Odontolabis gracilis

Odontolabis inaequalis

Odontolabis lacordairii

Odontolabis latipennis

Odontolabis lowii

Odontolabis ludekingi

Odontolabis ludekingi

Odontolabis mouhoti

Odontolabis platynotus

Odontolabis sinensis

Odontolabis siva

Odontolabis sommeri

Odontolabis stevensi

Odontolabis striatus

Odontolabis striatus var. cephalotes

Odontolabis vollenhoveni

Odontolabis wollastoni

Odontopus cupreus

Ogcoosoma granularis

Oiceoptoma tetraspilotum

Oides pallidipennis

Opilus auripennis

Orthorrhinus postoculatus

Papuana angusta

Phaenomeris magnifica

Pholidotus irroratus

Phrynetopsis kolbei

Phrystola ellioti

Piesarthrius marginellus

Prionus cumingii

Prionus hayesil

Prionus pertii

Prioscelis (Iphius)

$$
\text { crassicornis }
$$

Prioscelis (Iphius) raddoni

Prioscelis (Iphius) serrata

Prioscelis fabricii

Ptolycus nodosus

Pycnocerus westermanni

Sceliages iopas

Scolecobrotus westwoodii

Setenis costipennis

Sparganobasis subcruciatus

Stenochorus gigas

Stenochorus mitchelli

Stenochorus rubripes

Stenochorus trimaculatus
Wilson, 11: Plate 92

Wilson, 11: Plate 90

Wilson, 11: Plate 96

Wilson, 11: Plate 91

Wilson, 11: Plate 96

Wilson, 11: Plate 87

Wilson, 11: Plate 96

Wilson, 11: Plate 94

Wilson, 11: Plate 96

Wilson, 11: Plate 95

Wilson, 11: Plate 93

Wilson, 11: Plate 94

Wilson, 11: Plate 91

Wilson, 11: Plate 88

Wilson, 11: Plate 91

Wilson, 11: Plate 86

Wilson, 11: Plate 95

Wilson, 11: Plate 90

Wilson, 11: Plate 97

Wilson, 11: Plate 97

Wilson, 11: Plate 93

Wilson, 11: Plate 93

Westwood, 3: Plate 15

Westwood, 3: Plate 15

Westwood, 1: Plate 13

Knight, 19: Plate 7

Westwood, 1: Plate 13

Knight, 20: Plate 39

Knight, 20: Plate 39

Westwood, 1: Plate 13

Westwood, 1: Plate 14

Knight, 19: Plate 6

Knight, 19: Plate 6

Unsigned, 3: Plate 12

Westwood, 1: Plate 14

Westwood, 1: Plate 16

Westwood, 1: Plate 15

Westwood, 3: Plate 14

Westwood, 3: Plate 14

Westwood, 3: Plate 14 Westwood, 3: Plate 14 Knight, 20: Plate 39

Westwood, 3: Plate 15

Westwood, 2: Plate 2y

Westwood, 1: Plate 15

Knight, 20: Plate 39

Knight, 20: Plate 39

Unsigned, 3: Plate 12

Unsigned, 3: Plate 12

Unsigned, 3: Plate 12

Unsigned, 3: Plate 12 
Stenochorus uniguttatus

Sternotomis runsoriensis

Strongylium wollastoni

Strongylurus scuteilatus

Tmesisternus (Polyxo) bialbatus Knight, 20: Plate 39

Tmesisternus (Polyxo) laticollis Knight, 20: Plate 39

Tmesisternus cinctus

Tmesisternus modestus

Tmesisternus multiplicatus

Tmesisternus taeniatus

Trigonoptera albonotata

Uracanthus triangularis
Unsigned, 3: Plate 12

Knight, 19: Plate 6

Knight, 20: Plate 39

Unsigned, 3: Plate 12
Knight, 20: Plate 39

Knight, 20: Plate 39

Knight, 20: Plate 39

Knight, 20: Plate 39

Knight, 20: Plate 39

Westwood, 1: Plate 15 
Acantholipes ochrota Acerbas martini Acerbas nitidifasciata Acerbas nitidifasciata Acherontia medusa Acherontia morta Acosmeryx anceus Acraea amicitiae Acraea buxtoni Acraea encedon Acraea petroaea Acraea rahira Actias luna Actias mimosae Adris tyrannus Aeromachus discreta Aeromachus dubius Aeromachus dubius Aeromachus inachus Aeromachus inachus Aeromachus indistincta Aeromachus indistincta Aeromachus javanicus Aeromachus jhora Aeromachus nanus Aeromachus stigmata Aglaia tau Agrotis elaeopis Agrotis segetis Alcidia boops Alcidia metaurus Alcidia orontes Amblypodia narada Ambulyx lahora Ambulyx liturata Ambulyx postica Ambulyx rhodoptera Ambulyx turbata Ampelophaga rubiginosa Amphonyx rivularis Anadiasa leucocyma Ancistroides othonias Apisa metarctioides Apluda incincta Arboricornis chrysopepla Argadesa materna Argadesa materna Arhopala acetes Arhopala acron Arhopala admete var. waigeoensis

Arhopala adonias Arhopala adriana
Knight, 19: Plate 4 Edwards, 14: Plate 24 Edwards, 14: Plate 24 Unsigned, 14: Plate 20 Mintern, 9: Plate 92 Mintern, 9: Plate 92 Butler, 9: Plate 90 Knight, 19: Plate 5 Fawcett, 15: Plate 46 Fawcett, 15: Plate 46 Fawcett, 15: Plate 46 Fawcett, 15: Plate 46 Westwood, 10: Plate 86 Fawcett, 15: Plate 47 Moore, 11: Plate 13 Knight, 14: Plate 19 Edwards, 14: Plate 23 Knight, 14: Plate 19 Edwards, 14: Plate 23 Knight, 14: Plate 19 Edwards, 14: Plate 23 Knight, 14: Plate 19 Knight, 14: Plate 19 Edwards, 14: Plate 23 Edwards, 14: Plate 23 Knight, 14: Plate 19 Westwood, 10: Plate 86 Knight, 19: Plate 4 Fawcett, 15: Plate 49 Westwood, 10: Plate 87 Westwood, 10: Plate 87 Westwood, 10: Plate 85 Purkiss, 17: Plate 4 Mintern, 9: Plate 93 Butler, 9: Plate 91 Fawcett, 17: Plate 7 Mintern, 9: Plate 93 Mintern, 9: Plate 93 Butler, 9: Plate 91 Smith, 9: Plate 94 Knight, 19: Plate 4 Unsigned, 14: Plate 21 Knight, 19: Plate 4 Knight, 19: Plate 4 Knight, 19: Plate 4 Moore, 11: Plate 12 Moore, 11: Plate 14 Purkiss, 17: Plate 3 Purkiss, 17: Plate 3

Purkiss, 17: Plate 3 Purkiss, 17: Plate 2 Purkiss, 17: Plate 5 
Arhopala aedias

Arhopala aenea

Arhopala aenotria

Arhopala aexone

Arhopala agesias

Arhopala agesilaus

Arhopala agesilaus

Arhopala alce

Arhopala alemon

Arhopala alitaeus

Arhopala allata

Arhopala amantes

Arhopala ammonides

Arhopala amphimuta

Arhopala amytis

Arhopala anamuta

Arhopala andamanica

Arhopala annulata

Arhopala anthore

Arhopala anunda

Arhopala anunda

Arhopala anunda pale blue var.

Arhopala anunda var.

Arhopala apidanus

Arhopala argesias

Arhopala ariel

Arhopala aroa

Arhopala asopia

Arhopala atosia

Arhopala atrax

Arhopala auxesia

Arhopala barami

Arhopala basiviridis

Arhopala basiviridis

Arhopala bazaloides

Arhopala bazaloides

Arhopala brahma

Arhopala brookei

Arhopala buddha

Arhopala canulia

Arhopala catori

Arhopala catori

Arhopala centaurus

Arhopala chinensis

Arhopala chinensis

Arhopala corinda

Arhopala davaoana

Arhopala deva

Arhopala diardi

Arhopala dodonea

Arhopala dohertyi

Arhopala dohertyi

Arhopala elopura

Arhopala epimete
Purkiss, 17: Plate 3 Purkiss, 17: Plate 5 Purkiss, 17: Plate 3 Purkiss, 17: Plate 3 Purkiss, 17: Plate 5 Purkiss, 17: Plate 2 Purkiss, 17: Plate 5 Purkiss, 17: Plate 5 Purkiss, 17: Plate 5 Purkiss, 17: Plate 4 Purkiss, 17: Plate 3 Purkiss, 17: Plate 4 Purkiss, 17: Plate 3 Purkiss, 17: Plate 2 Purkiss, 17: Plate 4 Purkiss, 17: Plate 3 Purkiss, 17: Plate 4 Purkiss, 17: Plate 4 Purkiss, 17: Plate 4 Purkiss, 17: Plate 3 Purkiss, 17: Plate 5

Purkiss, 17: Plate 3 Purkiss, 17: Plate 3 Purkiss, 17: Plate 5 Purkiss, 17: Plate 3 Purkiss, 17: Plate 3 Purkiss, 17: Plate 5 Purkiss, 17: Plate 3 Purkiss, 17: Plate 5 Purkiss, 17: Plate 3 Purkiss, 17: Plate 3 Purkiss, 17: Plate 3 Purkiss, 17: Plate 2 Purkiss, 17: Plate 5 Purkiss, 17: Plate 1 Purkiss, 17: Plate 4 Purkiss, 17: Plate 2 Purkiss, 17: Plate 1 Purkiss, 17: Plate 3 Purkiss, 17: Plate 3 Purkiss, 17: Plate 2 Purkiss, 17: Plate 5 Purkiss, 17: Plate 4 Purkiss, 17: Plate 3 Purkiss, 17: Plate 5 Purkiss, 17: Plate 3 Purkiss, 17: Plate 2 Purkiss, 17: Plate 5 Purkiss, 17: Plate 5 Purkiss, 17: Plate 5 Purkiss, 17: Plate 1 Purkiss, 17: Plate 4 Purkiss, 17: Plate 5 Purkiss, 17: Plate 3 
Arhopala epimuta Arhopala epimuta Arhopala eridanus Arhopala eridanus Arhopala eumolphus Arhopala eumolphus Arhopala eupolis Arhopala ganesa Arhopala gunongensis Arhopala helius Arhopala helius var. anthelius

Arhopala hercules Arhopala hercules var. herculina Arhopala hesba Arhopala hewitsoni Arhopala hewitsoni Arhopala horsfieldi Arhopala hypomuta Arhopala ijauensis Arhopala inornata Arhopala irregularis Arhopala japonica Arhopala japonica Arhopala kiriwinii Arhopala kuhni Arhopala malayica Arhopala meander Arhopala metamuta Arhopala mindanensis Arhopala moolaiana Arhopala moorei Arhopala morphina Arhopala muta Arhopala myrtale Arhopala myrtha Arhopala nicévillei Arhopala nobilis Arhopala oberthuri Arhopala padus Arhopala padus Arhopala padus blue Arhopala paraganesa Arhopala paramuta Arhopala perissa Arhopala phaenops Arhopala philander Arhopala pseudomuta Arhopala quercoides Arhopala rama Arhopala sangira Arhopala singla Arhopala staudingeri Arhopala tephlis
Purkiss, 17: Plate 2 Purkiss, 17: Plate 5 Purkiss, 17: Plate 1 Purkiss, 17: Plate 4 Purkiss, 17: Plate 2 Purkiss, 17: Plate 5 Purkiss, 17: Plate 1 Purkiss, 17: Plate 4 Purkiss, 17: Plate 2 Purkiss, 17: Plate 1

Purkiss, 17: P1ate 1 Purkiss, 17: Plate 4

Purkiss, 17: Plate 1 Purkiss, 17: Plate 3 Purkiss, 17: Plate 3 Purkiss, 17: Plate 5 Purkiss, 17: Plate 2 Purkiss, 17: P1ate 2 Purkiss, 17: Plate 1 Purkiss, 17: Plate 2 Purkiss, 17: Plate 2 Purkiss, 17: Plate 3 Purkiss, 17: Plate 4 Purkiss, 17: Plate 1 Purkiss, 17: Plate 2 Purkiss, 17: Plate 2 Purkiss, 17: Plate 4 Purkiss, 17: Plate 5 Purkiss, 17: Plate 1 Purkiss, 17: Plate 2 Purkiss, 17: Plate 5 Purkiss, 17: Plate 2 Purkiss, 17: Plate 5 Purkiss, 17: Plate 1 Purkiss, 17: Plate 1 Purkiss, 17: Plate 2 Purkiss, 17: Plate 2 Purkiss, 17: Plate 2 Purkiss, 17: Plate 1 Purkiss, 17: Plate 4 Purkiss, 17: Plate 1 Purkiss, 17: Plate 4 Purkiss, 17: Plate 4 Purkiss, 17: Plate 3 Purkiss, 17: Plate 1 Purkiss, 17: Plate 4 Purkiss, 17: Plate 1 Purkiss, 17: Plate 1 Purkiss, 17: Plate 5 Purkiss, 17: Plate 1 Purkiss, 17: Plate 5 Purkiss, 17: Plate 2 Purkiss, 17: Plate 1 
Arhopala tephlis

Arhopala theba

Arhopala tounguva

Arhopala vihara

Arhopala viola

Arhopala viola

Arhopala viola var.

Arhopala wildei

Ariathisa semiluna

Arnetta vindhiana

Asthenidia podaliriaria

Astictopterus henrici

Astictopterus olivascens

Attacus pavonia minor

Augiades brahma

Augiades crateis

Augiades majuscula

Augiades majuscula

Augiades ochracea

Augiades siva

Augiades subhyalina

Augiades sylvanoides

Baracus hampsoni

Basiana exusta

Beralade strigifascia

Bibasis sambavana

Bibasis uniformis

Bleptina nephelopera

Boarmia acaciaria

Boisduval

Borolia phaeopasta

Borolia pyrostrota

Bunaea caffraria

Bunaea tyrrhena

Byblia ilithyia

Calamistis obliquifascia

Callicore anna

Callicore asteria

Callicore candrena

Callicore candrena

Callicore ceryx

Callicore clymena

Callicore clymena

Callicore euclides

Callicore eupepla

Callicore gabaza

Callicore kolyma

Callicore lidwina

Callicore marchalii

Callicore neglecta

Callicore phogea

Callioratis bellatrix

Calymnia ethiopica

Caprona ransonnettii

Caprona saraya
Purkiss, 17: Plate 4

Purkiss, 17: Plate 4

Purkiss, 17: Plate 3

Purkiss, 17: Plate 2

Purkiss, 17: Plate 1

Purkiss, 17: Plate 3

Purkiss, 17: Plate 3

Purkiss, 17: Plate 1

Knight, 19: Plate 4

Knight, 14: Plate 18

Westwood, 10: Plate 86

Knight, 14: Plate 18

Knight, 14: Plate 18

Westwood, 10: Plate 86

Edwards, 14: Plate 25

Edwards, 14: Plate 25

Edwards, 14: Plate 25

Knight, 14: Plate 19

Edwards, 14: Plate 24

Knight, 14: Plate 19

Edwards, 14: Plate 24

Edwards, 14: Plate 24

Knight, 14: Plate 18

Mintern, 9: Plate 93

Knight, 19: Plate 4

Edwards, 14: Plate 27

Edwards, 14: Plate 27

Knight, 19: Plate 4

Fawcett, 15: Plate 49

Knight, 19: Plate 4

Knight, 19: Plate 4

Fawcett, 15: Plate 47

Fawcett, 17: Plate 6

Fawcett, 17: Plate 6

Knight, 19: Plate 4

Schwanwitsch, 21: Plate 9

Schwanwitsch, 21: Plate 9

Schwanwitsch, 21: Plate 9

Schwanwitsch, 21: Plate 9

Schwanwitsch, 21: Plate 9

Schwanwitsch, 21: Plate 9

Schwanwitsch, 21: Plate 9

Schwanwitsch, 21: Plate 9

Schwanwitsch, 21: Plate 9

Schwanwitsch, 21: Plate 9

Schwanwitsch, 21: Plate 9

Schwanwitsch, 21: Plate 9

Schwanwitsch, 21: Plate 9

Schwanwitsch, 21: Plate 9

Schwanwitsch, 21: Plate 9

Fawcett, 17: Plate 8

Knight, 19: Plate 4

Edwards, 14: Plate 23

Edwards, 14: Plate 23 
Caprona saraya

Catada phaeopasta

Catagramma sp.

Catagramma apollinaris

Catagramma astarte

Catagramma astarte

Catagramma astarte miles

Catagramma astarte rutila

Catagramma astarte selima

Catagramma astarte stratiotes

Catagramma atacama

Catagramma brome

Catagramma costa

Catagramma cyllene

Catagramma cynosura

Catagramma denina

Catagramma egina

Catagramma eunomia

Catagramma eunomia carmen

Catagramma excelsior var. pastazza

Catagramma faustina

Catagramma felderi

Catagramma hesperis

Catagramma hydarnis

Catagramma hydaspes

Catagramma latona

Catagramma lyca

Catagramma lyrophila

Catagramma lyrophila

Catagramma maimuna

Catagramma monina

Catagramma odilia

Catagramma pacifica

Catagramma pasithea

Catagramma pasithea

Catagramma peristera

Catagramma pitheas

Catagramma pygas

Catagramma pyracmon

Catagramma sorana

Catagramma texa

Catagramma titania

Catagramma tolima

Catagramma zelphanta

Celaenorrhinus affinis

Celaenorrhinus affinis

Celaenorrhinus andamanica

Celaenorrhinus aurovittata

Celaenorrhinus balukinus

Celaenorrhinus batchianus

Celaenorrhinus dentatus

Celaenorrhinus dhanada

Celaenorrhinus fluvescens
Knight, 14: Plate 18

Knight, 19: Plate 4

Schwanwitsch, 21: Plate 12

Schwanwitsch, 21: Plate 11

Schwanwitsch, 21: Plate 10

Schwanwitsch, 21: Plate 10

Schwanwitsch, 21: Plate 10

Schwanwitsch, 21: Plate 10

Schwanwitsch, 21: Plate 10

Schwanwitsch, 21: Plate 10 Schwanwitsch, 21: Plate 11 Schwanwitsch, 21: Plate 12 Schwanwitsch, 21: Plate 11 Schwanwitsch, 21: Plate 10 Schwanwitsch, 21: Plate 11 Schwanwitsch, 21: Plate 11 Schwanwitsch, 21: Plate 12 Schwanwitsch, 21: Plate 11 Schwanwitsch, 21: Plate 11

Schwanwitsch, 21: Plate 10 Schwanwitsch, 21: Plate 11 Schwanwitsch, 21: Plate 11 Schwanwitsch, 21: Plate 11 Schwanwitsch, 21: Plate 11 Schwanwitsch, 21: Plate 12 Schwanwitsch, 21: Plate 10 Schwanwitsch, 21: Plate 12 Schwanwitsch, 21: Plate 12 see Catagramma hydaspes Schwanwitsch, 21: Plate 12 Schwanwitsch, 21: Plate 12 Schwanwitsch, 21: Plate 12 Schwanwitsch, 21: Plate 11 Schwanwitsch, 21: Plate 10 Schwanwitsch, 21: Plate 9 Schwanwitsch, 21: Plate 11 Schwanwitsch, 21: Plate 12 Schwanwitsch, 21: Plate 10 Schwanwitsch, 21: Plate 11 Schwanwitsch, 21: Plate 10 Schwanwitsch, 21: Plate 12 Schwanwitsch, 21: Plate 12 Schwanwitsch, 21: Plate 11 Schwanwitsch, 21: Plate 11 Edwards, 14: Plate 22 Knight, 14: Plate 18 Edwards, 14: Plate 22 Edwards, 14: Plate 22 Knight, 14: Plate 18 Knight, 14: Plate 18 Knight, 14: Plate 18 Edwards, 14: Plate 22 Knight, 14: Plate 18 
Celaenorrhinus inaequalis

Celaenorrhinus lativittus

Celaenorrhinus maculicornis

Celaenorrhinus orbiferus

Celaenorrhinus saturatus

Celaenorrhinus saturatus

Celerio annei

Celerio annei

Celerio lineata lineata

Celerio lineata lineata

Cephonodes hylas

Chaerocampa balsaminae

Chaerocampa capens is

Chaerocampa docilis

Chaerocampa eson

Chaerocampa idricus

Chaerocampa japonica

Chaerocampa lewisii

Chaerocampa mirabilis

Chaerocampa oldenlandiae

Chaerocampa orpheus

Chaerocampa osiris

Chaerocampa silhetensis

Chaerocampa virescens

Charaxes candiope

Charaxes opinatus

Charaxes varanes

Chioneigia leggei

Chrysiridia rhipheus

Chrysopsyche leucostigma

Cidaria thermochroa

Cirina forda

Cocytius antaeus medor

Cocytius antaeus medor

Coladenia agni

Coladenia agni

Coladenia agnioides

Coladenia agnioides

Coladenia dan

Coladenia laxmi

Coladenia sobrina

Comibaena biviaria

Copaxa flavinata

Coronidia aeola

Coronidia aeola

Coronidia biblina

Coronidia boreada

Coronidia boreada

Coronidia briseis

Coronidia columbiana

Coronidia egina

Coronidia erecthea

Coronidia genevana

Coronidia granadina
Knight, 14: Plate 18 Knight, 14: Plate 18

Knight, 14: Plate 18 Knight, 14: Plate 18 Edwards, 14: Plate 22 Knight, 14: Plate 18 Moss, 20: Plate 14 Moss, 20: Plate 15 Moss, 20: Plate 14 Moss, 20: Plate 15 Fawcett, 15: Plate 48 Fawcett, 15: Plate 48 Fawcett, 15: Plate 47 Smith, 9: Plate 94 Fawcett, 17: Plate 8 Fawcett, 15: Plate 49 Butler, 9: Plate 9l Butler, 9: Plate 90 Mintern, 9: Plate 92 Butler, 9: Plate 91 Fawcett, 17: Plate 7 Fawcett, 15: Plate $4 \delta$ Mintern, 9: Plate 92 Smith, 9: Plate 94 Fawcett, 15: Plate 46 Knight, 19: Plate 5 Fawcett, 17: Plate 6 Knight, 19: Plate 5 Westwood, 10: Plate 85 Knight, 19: Plate 4 Knight, 19: Plate 4 Fawcett, 17: Plate 6 Moss, 20: Plate 15 Moss, 20: Plate 7 Edwards, 14: Plate 22 Edwards, 14: Plate 22 Edwards, 14: Plate 22 Knight, 14: Plate 18 Edwards, 14: Plate 22 Edwards, 14: Plate 22 Knight, 14: Plate 18 Knight, 19: Plate 4 Fawcett, 17: Plate 6 Westwood, 10: Plate 85 Westwood, 10: Plate 88 Westwood, 10: Plate 88 Westwood, 10: Plate 85 Westwood, 10: Plate 87 Westwood, 10: Plate 88 Westwood, 10: Plate 88 Westwood, 10: Plate 87 Westwood, 10: Plate 87 Westwood, 10: Plate 88 Westwood, 10: Plate 88 
Coronidia interlineata

Coronidia japet

Coronidia leachii

Coronidia nicaraguana

Coronidia orithea

Coronidia orithea var.

Coronidia paulina

Coronidia rosina

Crenis boisduvali

Crenis natalensis

Ctenoptilum chinensis

Ctenoptilum vasava

Cyclogramma bacchis

Cyclogramma bacchis

Cyclogramma pandama

Daphnis minima

Dasychira georgiana

Diacrisia melanodisca

Diludia melanomera

Diludia natalensis

Diludia vates

Diota reticulata

Dulichia fasciata

Earias insulana Boisduval

Egybolis vaillantina

Emmatheudes lentistrigalis

Endromis versicolor

Epicopeia polydora

Episilia rhodopea

Epitoxis albicincta

Erebus (Patula) macrops

Ergolis pagensteckeri

Ergolis pagensteckeri forma $n$. aurantiaca

Erinnyis alope

Erinnyis ello

Erinnyis ello

Estigmene atropunctata

Estigmene dissimilis

Euchloris devocata

Eudaemonia semiramis

Euproctis croceisticta

Euproctis melalepia

Euricania stellata

Euryglottis davidianus

Euryglottis davidianus

Eurytela hiarbas

Eusemia butleri

Gangara sanguinocculus

Gastropacha quercifolia

Gehenna angulifera

Glottula pancratii

Glyphodes aniferalis

Gnophodes chelys

Gnophodes diversa
Westwood, 10: Plate 88 Westwood, 10: Plate 88 Westwood, 10: Plate $\delta \delta$ Westwood, 10: Hlate $8 \delta$ Westwood, 10: Plate 85 Westwood, 10: Plate 87 Westwood, 10: Plate 87 Westwood, 10: Plate 87 Fawcett, 17: Plate 6 Fawcett, 17: Plate 6 Edwards, 14: Plate 23 Edwards, 14: Plate 22 Schwanwitsch, 21: Plate $\delta$ Schwanwitsch, 21: Plate 9 Schwanwitsch, 21: Plate 8 Mintern, 9: Plate 92 Fawcett, 15: Plate 49 Knight, 19: Plate 4 Smith, 9: Plate 94 Smith, 9: Plate 94 Butler, 9: Plate 91 Knight, 19: Plate 4 Fawcett, 15: Plate 49 Fawcett, 15: Plate 49 Fawcett, 17: Plate 8 Knight, 19: Plate 4 Westwood, 10: Plate 86 Westwood, 10: Plate 86 Knight, 19: Plate 4 Knight, 19: Plate 4 Westwood, 10: Plate 86 Knight, 19: Plate 5

Knight, 19: Plate 5 Moss, 20: Plate 9 Moss, 20: Plate 15 Moss, 20: Plate 9

Fawcett, 17: Plate 7 Fawcett, 17: Plate 7 Fawcett, 17: Plate 8 Westwood, 10: Plate 86 Knight, 19: Plate 4 Knight, 19: Plate 4 Knight, 20: Plate 34 Moss, 20: Plate 15 Moss, 20: Plate 7 Fawcett, 17: Plate 6 Fawcett, 15: Plate 47 Unsigned, 14: Plate 20 Westwood, 10: Plate 86 Knight, 14: Plate 19 Fawcett, 15: Plate 49 Knight, 19: Plate 4 Knight, 19: Plate 5 Knight, 19: Plate 5 
Gnophodes grogani

Gnophodes minchini

Gnophodes minchini

forma n. Magniplaga

Gnophodes parmeno

Gonometa postica

Goodia oriens

Gynanisa maia

Halpe beturia

Halpe debilis

Halpe debilis

Halpe fasciata

Halpe fusca

Halpe homolea

Halpe knyvetti

Halpe majuscula

Halpe sikkima

Harpendyreus reginaldi

Hasora borneensis

Hasora borneensis

Hasora chromus

Hasora inermis

Hasora inermis

Hasora mus

Hasora mus

Hasora proxissima

Hemaris hylas

Henucha delegorguei

Henucha smilax

Heronax wollastoni

Herse cingulata

Herse cingulata

Hesperia alveus

Hesperia geron

Hesperia malvae

Hesperia malvoides

Hesperia melotis

Hesperia onopordi

Hesperia phlomidis

Hesperia proto

Hesperia serratulae

Hesperia speyeri

Hesperia staudingeri

Hydria undulata

Hyloicus juniperi

Hypena recurvata

Hypocrosis glaucaria

Hypocrosis maculifera

Hypoglaucitis polycyma

Hypsa aphidas

Iambrix latifascia

Iraota lazarena

Iraota timoleon

Ismene lara

Ismene tuckeri
Knight, 19: Plate 5

Knight, 19: Plate 5

Knight, 19: Plate 5

Knight, 19: Plate 5

Fawcett, 15: Plate 49

Knight, 19: Plate 4

Fawcett, 15: Plate 47

Unsigned, 14: Plate 21

Unsigned, 14: Plate 21

Unsigned, 14: Plate 21

Unsigned, 14: Plate 21

Edwards, 14: Plate 25

Edwards, 14: Plate 25

Unsigned, 14: Plate 21

Unsigned, 14: Plate 21

Edwards, 14: Plate 25

Knight, 19: Plate 5

Unsigned, 14: Plate 20

Unsigned, 14: Plate 20

Edwards, 14: Plate 27

Edwards, 14: Plate 27

Unsigned, 14: Plate 20

Unsigned, 14: Plate 20

Unsigned, 14: Plate 20

Unsigned, 14: Plate 21

Butler, 9: Plate 90

Fawcett, 17: Plate 6

Fawcett, 17: Plate 6

Knight, 20: Plate 34

Moss, 20: Plate 15

Moss, 20: Plate 8

Edwards, 14: Plate 23

Edwarảs, 14: Plate 23

Edwards, 14: Plate 23

Edwards, 14: Plate 23

Edwards, 14: Plate 23

Edwards, 14: Plate 23

Edwards, 14: Plate 23

Edwards, 14: Plate 23

Edwards, 14: Plate 23

Edwards, 14: Plate 23

Edwards, 14: Plate 23

Westwood, 10: Plate 86

Fawcett, 17: Plate 7

Knight, 19: Plate 4

Knight, 19: Plate 4

Knight, 19: Plate 4

Knight, 19: Plate 4

Fawcett, 15: Plate 47

Unsigned, 14: Plate 21

Purkiss, 17: Plate 1

Purkiss, 17: Plate 4

Unsigned, 14: Plate 20

Unsigned, 14: Plate 20 
Isognathus amazonicus Isognathus metascyron Isognathus swainsoni Junonia cebrene Junonia clelia Khadira aurantia Larentia chlorostola Larentia heteromorpha Leucoma atricosta Lophoides binotatus Lophoides iapis Lophoides purpurascens Lophoides purpurascens Lophostethus dumolinii Lophura hyas Lophuron marginatum Lucinia cadma Lucinia sida Lucinia sida Lucinia torrebia Ludia smilax Lycophotia leucoplaga Lysidia patroclus Macaria atriclathrata Macaria trizonaria Macroglossa belis Macroglossa gilia Macroglossa pyrrhosticta Maenas salaminia Maenas salaminia Mahathala ameria Mahathala hainana Manidia lunus Marshalliana arcifera Matapa driona Matapa purpurascens Matapa purpurascens Metanastria aculeata Metarctia flaviciliata Metarctia meteus Metarctia pulverea Nemoria brunneifrons Nephele hespera Nephele rosae

Nephele variegata Notocrypta inornata Notocrypta quadrata Nudaurelia belina Nudaurelia wahlbergi Olapa melanocera Ophiusa indeterminata Orophila sp. Orophila calamis Orophila cardases Orophila diotima

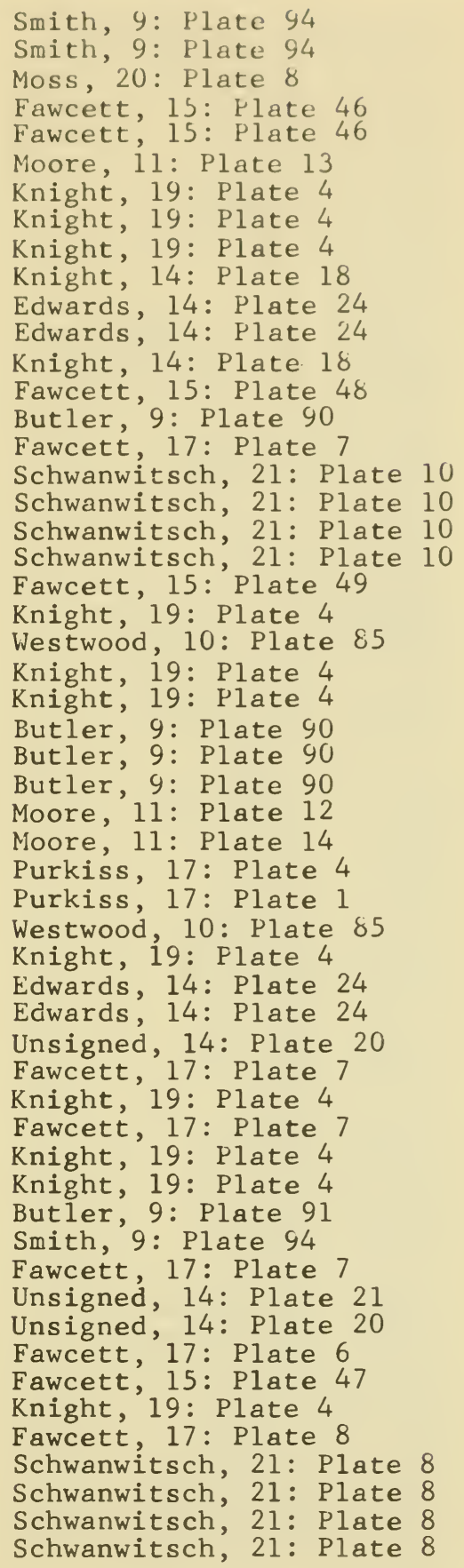


Orthophoetus 1idderdali

Osteodes pervittata

Othreis ancilla

Othreis ancilla

Othreis cajeta

Othreis fullonica

Othreis fullonica

Oxypalpus wollastoni

Pachylia ficus

Pachylia ficus

Pachylia syces syces

Pachylia syces syces

Pamphila niveomaculatus

Panacra ella

Panacra regularis

Papilio brasidas

Papilio demodocus

Papilio morania

Papilio nireus

var. lyaeus

Papilio policenes

Papuanella mirabilis

Parathermes nubilata

Parnara aurociliata

Parnara aurociliata

Parnara austeni

Parnara bevani

Parnara bipunctata

Parnara cahira

Parnara cahira

Parnara colaca

Parnara conjuncta

Parnara contigua

Parnara discreta

Parnara discreta

Parnara eltola

Parnara guttatus

Parnara hasoroides

Parnara kumara

Parnara leechii

Parnara leechii

Parnara mathias

Parnara moolata

Parnara oceia

Parnara pellucida

Parnara philippina

Parnara philippina

Parnara philippina

Parnara robusta

Parnara robusta

Parnara simillima

Parnara simillima

Parnara subochracea

Parnara subochracea

Pedestes fuscicornis
Unsigned, 14: Plate 20 Knight, 19: Plate 4 Moore, 11: Plate 12 Moore, 11: Plate 13 Moore, 11: Plate 13 Moore, 11: Plate 12 Moore, 11: Plate 13 Knight, 19: Plate 5 Moss, 20: Plate 10 Moss, 20: Plate 15 Moss, 20: Plate 10 Moss, 20: Plate 15 Knight, 14: Plate 19 Mintern, 9: Plate 92 Mintern, 9: Plate 92 Fawcett, 15: Plate 46 Fawcett, 15: Plate 46 Fawcett, 15: Plate 46

Fawcett, 15: Plate 46 Fawcett, 15: Plate 46 Knight, 20: Plate 34 Knight, 19: Plate 4 Edwards, 14: Plate 26 Unsigned, 14: Plate 21 Edwards, 14: Plate 27 Edwards, 14: Plate 26 Knight, 14: Plate 19 Edwards, 14: Plate 27 Unsigned, 14: Plate 21 Edwards, 14: Plate 26 Edwards, 14: Plate 27 Edwards, 14: Plate 26 Edwards, 14: Plate 26 Unsigned, 14: Plate 21 Edwards, 14: Plate 26 Edwards, 14: Plate 26 Unsigned, 14: Plate 21 Edwards, 14: Plate 27 Edwards, 14: Plate 25 Unsigned, 14: Plate 21 Edwards, 14: Plate 26 Edwards, 14: Plate 26 Edwards, 14: Plate 25 Edwards, 14: Plate 26 Edwards, 14: Plate 26 Unsigned, 14: Plate 21 Unsigned, 14: Plate 21 Edwards, 14: Plate 27 Unsigned, 14: Plate 21. Edwards, 14: Plate 26 Unsigned, 14: Plate 21 Edwards, 14: Plate 26 Unsigned, 14: Plate 21 Edwards, 14: Plate 24 
Pedestes fuscicornis

Pedestes maculicornis

Pedestes maculicornis

Pedestes masuriensis

Pedestes pandita

Pergesa aegrota

Pergesa gloriosa

Pergesa mongoliana

Perisama sp.

Perisama comnena var. intermedia

Perisama eminens

Perisama emma emilina

Perisama euriclea

Perisama goeringi

Perisama hilara

Perisama hilara

Perisama lebasii

Perisama patara

Perisama saussurei

Perisama vaninka

Perisama volara

Perisama xanthica

Petovia dichroaria

Phissama flava

Phissama screabile

Pholus anchemolus

Pholus fasciatus

Pholus fasciatus

Pholus labruscae

Pholus labruscae

Pholus vitis vitis

Pholus vitis vitis

Phyllalia flavicostata

Phyllalia patens

Pieris gidica

Pieris hellica

Pieris severina

Pilocrocis laralis

Pilocrocis patagialis

Pirdana albicornis

Plastingia aurantiaca

Plastingia callineura

Plastingia fruhstorferi

Plastingia fruhstorferi

Plastingia latoia

Plastingia margherita

Plastingia noemi

Plastingia similis

Plastingia similis

Pleurona lepticyma

Plusia aranea

Plusia cupreomicans

Polydesma glaucinans Guen.

Polyptychus dentatus
Knight, 14: Plate 18

Edwards, 14: Plate 24

Knight, 14: Plate 18

Edwards, 14: Plate 24

Edwaras, 14: Plate 24

Mintern, 9: Plate 92

Mintern, 9: Plate 92

Butler, 9: Plate 9l

Schwanwitsch, 21: Plate 8

Schwanwitsch, 21: Plate 8 Schwanwitsch, 21: Plate 8 Schwanwitsch, 21: Plate 8 Schwanwitsch, 21: Plate 8 Schwanwitsch, 21: Plate 8 Schwanwitsch, 21: Plate 8 Schwanwitsch, 21: Plate 8 Schwanwitsch, 21: Plate 8 Schwanwitsch, 21: Plate 8 Schwanwitsch, 21: Plate 8 Schwanwitsch, 21: Plate 8 Schwanwitsch, 21: Plate 8 Schwanwitsch, 21: Plate 8 Fawcett, 17: Plate 8

Fawcett, 15: Plate 49

Fawcett, 15: Plate 49

Moss, 20: Plate 12

Moss, 20: Plate 11

Moss, 20: Plate 15

Moss, 20: Plate 13

Moss, 20: Plate 15

Moss, 20: Plate 12

Moss, 20: Plate 15

Fawcett, 17: Plate 6

Fawcett, 17: Plate 6

Fawcett, 17: Plate 6

Fawcett, 15: Plate 46

Fawcett, 15: Plate 46

Knight, 19: Plate 4

Knight, 19: Plate 4

Unsigned, 14: Plate 21

Knight, 14: Plate 19

Edwards, 14: Plate 24

Edwards, 14: Plate 24

Knight, 14: Plate 19

Edwards, 14: Plate 24

Edwards, 14: Plate 24

Edwards, 14: Plate 24

Edwards, 14: Plate 24

Knight, 14: Plate 19

Knight, 19: Plate 4

Knight, 19: Plate 4

Knight, 19: Plate 4

Fawcett, 15: Plate 49

Butler, 9: Plate 91 
Polyptychus grayi

Polythlipta guttiferalis

Protoparce diffissa tropicalis

Protoparce mauritii

Protoparce mossi

Protoparce mossi

Protoparce orientalis

Protoparce rustica rustica

Protoparce rustica rustica

Protoparce scutata

Protoparce sexta paphus

Protoparce sexta paphus

Pseudaphelia apollinaris

Pseudometa castanea

Pseudosphinx cyrtolophia

Pseudosphinx cyrtolophia

Pseudosphinx tetrio

Pseudosphinx tetrio

Psilocerea craspigonia

Psilocerea curvimargo

Psilocerea stictigramma

Purbia discrepans

Ramesa macrodonta

Remigia pectinata

Rhodogastria astreas var. bauri

Rhonidophora cinctigutta

Rhotala albopunctata

Rhotala nebulosa

Rhytia cocale

Rhytia cocale

Rhytia hypermnestra

Rhytia hypermnestra

Ricania noctua

Ricania subglauca

Sarangesa dasahara

Sarangesa purendra

Sarangesa sati

Satarupa fumosa

Scobura bipunctata

Scobura concinna

Scobura fenestrata

Scobura fenestrata

Scobura inarime

Scobura martini

Scobura umbrosa

Sepa cicatrosa

Sepa ciliata

Sepa cinnamomea

Sepa guttulifera

Smerinthus planus

Smerinthus tattarinovii

Spilosoma puella

Stenostaura impedita
Fawcett, 17: Plate 7

Knight, 19: Plate 4

Moss, 20: Plate 8

Fawcett, 15: Plate 48

Moss, 20: Plate 15

Moss, 20: Plate 7

Butler, 9: Plate 91

Moss, 20: Plate 15

Moss, 20: Plate 8

Moss, 20: Plate 8

Moss, 20: Plate 15

Moss, 20: Plate 7

Fawcett, 15: Plate 47

Knight, 19: Plate 4

Butler, 9: Plate 9l

Mintern, 9: Plate 92

Moss, 20: Plate 15

Moss, 20: Plate $\delta$

Knight, 19: Plate 4 Knight, 19: Plate 4 Knight, 19: Plate 4 Moore, 11: Plate 14 Knight, 19: Plate 4 Knight, 19: Plate 4

Fawcett, 17: Plate 7 Fawcett, 17: Plate 8 Knight, 20: Plate 34 Knight, 20: Plate 34 Moore, 11: Plate 12 Moore, 11: Plate 14 Moore, 11: Plate 12 Moore, 11: Plate 14 Knight, 20: Plate 34 Knight, 20: Plate 34 Edwards, 14: Plate 22 Edwards, 14: Plate 22 Edwards, 14: Plate 22 Knight, 14: Plate 18 Knight, 14: Plate 19 Knight, 14: Plate 19 Edwards, 14: Plate 24 Knight, 14: Plate 19 Edwards, 14: Plate 24 Knight, 14: Plate 18 Knight, 14: Plate 19 Knight, 14: Plate 19 Knight, 14: Plate 19 Knight, 14: Plate 19 Knight, 14: Plate 19 Mintern, 9: Plate 92 Butler, 9: Plate 90 Fawcett, 15: Plate 49 Knight, 19: Plate 4 
Strophidia vollenhovii

Suastus bipunctus

Suastus sala

Surendra amisena

Surendra amisena

Surendra amisena blue

Surendra vivarna

Taeniopyga sylvina

Tagiades atticus

Tagiades nana

Tagiades nestus

Tagiades sambavana

Tagiades sambavana

Tagiades titus

Tagiades waterstradti

Tapena hampsoni

Tapena hampsoni

Tapena minuscula

Tapena minuscula

Tapena thwaitesi

Tarache niphogona

Taractrocera ceramas

Taractrocera nicevillei

Taragama butiti

Taragama diplocyma

Telicota augiades

Telicota augias

Telicota bambusae

Telicota concinna

Telicota concinna

Telicota dara

Telicota dilutior

Telicota gola

Telicota insularis

Telicota palmarum

Telicota prusias

Telicota rectifasciata

Telicota rectifasciata

Telicota simplex

Tephrina oleochroa

Terina chrysoptera

Tetraphleps ruficeps

Thaduka multicaudata

Thanaos leechii

Thanaos marloyi

Thanaos montanus

Thanaos pelias

Trabala pallida

Triptogon albicans

Triptogon fuscescens

Triptogon massurensis

Triptogon oriens

Triptogon roseipennis

Triptogon spectabilis

Urania fernandina
Westwood, 10: Plate 86

Knight, 14: Plate 18

Knight, 14: Plate 18

Purkiss, 17: Plate 1

Purkiss, 17: Plate 4

Purkiss, 17: Plate 1

Purkiss, 17: Plate 1

Fawcett, 15: Plate 49

Edwards, 14: Plate 22

Unsigned, 14: Plate 20

Unsigned, 14: Plate 20

Edwards, 14: Plate 22

Unsigned, 14: Plate 2U

Unsigned, 14: Plate 20

Unsigned, 14: Plate 20

Edwards, 14: Plate 22

Knight, 14: Plate 18

Edwards, 14: Plate 22

Knight, 14: Plate 18

Edwards, 14: Plate 22

Knight, 19: Plate 4

Unsigned, 14: Plate 21

Unsigned, 14: Plate 21

Knight, 19: Plate 4

Knight, 19: Plate 4

Edwards, 14: Plate 25

Edwards, 14: Plate 25

Edwards, 14: Plate 25

Edwards, 14: Plate 25

Unsigned, 14: Plate 21

Edwards, 14: Plate 25

Unsigned, 14: Plate 21

Edwards, 14: Plate 25

Knight, 14: Plate 19

Edwards, 14: Plate 25

Knight, 14: Flate 19

Edwards, 14: Plate 25

Unsigned, 14: Plate 21

Knight, 14: Plate 19

Knight, 19: Plate 4

Knight, 19: Plate 4

Knight, 19: Plate 4

Purkiss, 17: Plate 4

Edwards, 14: Plate 23

Edwards, 14: Plate 23

Edwards, 14: Plate 23

Edwards, 14: Plate 23

Fawcett, 17: Plate 8

Mintern, 9: Plate 93

Mintern, 9: Plate 93

Mintern, 9: Plate 93

Mintern, 9: Plate 93

Butler, 9: Plate 91

Mintern, 9: Plate 93

Mcleay, 1: Plate 26 
Uranidia sloanus

Uranothauma delatorum

Uranothauma falkensteinii

Urapteryx sambucaria

Urota sinope

Usta terpischore

Utakwana rubromaculata

Watsonia swinhoei

Xylophanes tersa

Xylophanes tersa

Xylophanes titana

Xylopteryx prasinaria

Xylostola olivata

Zamarada chrysothyra

Zamarada phaeozona

Zana trifasciata

Zographetus auriferus

Zographetus ogygioides

Zygaena (Anteris) ampla
Westwood, 10: Plate 85

Knight, 19: Plate 5

Knight, 19: Plate 5

Westwood, 10: Plate 86

Fawcett, 15: Plate 47

Fawcett, 17: Plate 6

Knight, 20: Plate 34

Unsigned, 14: Plate 20

Moss, 20: Plate 14

Moss, 20: Plate 15

Moss, 20: Plate 13

Knight, 19: Plate 4

Knight, 19: Plate 4

Knight, 19: Plate 4

Knight, 19: Plate 4

Knight, 19: Plate 4

Knight, 14: Plate 19

Knight, 14: Plate 19

Fawcett, 15: Plate 49 
coral

coral

coral

coral

coral

coral

coral

coral

coral

coral

coral

coral

coral

coral

coral

coral

crab

crab

crab

crab

crab

crab

crab

crab

crab

crab

octapus

sea urchin

sponge

sponge

sponge

sponge

sponge

sponge

squid

squid

squid

squid

squid

squid

worm

worm

Acartia ensifera

Acholoë astericola

Actinia sanguineo-punctata

Adeonellopsis incisa

Adeonellopsis wetherelli

Adeonellopsis wetherelli

Aglaophenia dromaius

Aglaophenia elongata

Akidognathia aedipus

Alaotanais hastiger

Alaotanais laevispinosus
Berjeau, 13: Plate 11

Berjeau, 13: Plate 12

Dewilde, 8: Plate 41

Dewilde, 8: Plate 44

Dewilde, 8: Plate 47

Dewilde, 8: Plate 48

Erxleben, 10: Plate 43

Erxleben, 10: Plate 44

Erxleben, 10: Plate 45

Erxleben, 8: Plate 39

Erxleben, 8: Plate 40

Erxleben, 8: Plate 42

Erxleben, 8: Plate 43

Erxleben, 8: Plate 45

Erxleben, 8: Plate 46

Erxleben, 8: Plate 49

Westwood, 1: Plate 43

Westwood, 1: Plate 44

Westwood, 1: Plate 45

Westwood, 1: Plate 46

Westwood, 2: Plate 10

Westwood, 2: Plate 11

Westwood, 2: Plate 12

Westwood, 2: Plate 13

Westwood, 2: Plate 8

Westwood, 2: Plate 9

Erxleben, 11: Plate 23

Berjeau, 13: Plate 38

Mintern Bros, 12: Plate 58

Mintern Bros, 12: Plate 59

Mintern Bros, 12: Plate 60

Mintern Bros, 12: Plate 61

Mintern Bros, 12: Plate 62

Mintern Bros, 12: Plate 63

Erxleben, 11: Plate 28

Scharf, H., 11: Plate 27

Smit, 11: Plate 24

Smit, 11: Plate 25

Smit, 11: Plate 29

Smit, 11: Plate 33

Beddard, 12: Plate 14

Beddard, 12: Plate 15

Brady, 15: Plate 9

McIntosh, 9: Plate 70

Templeton, 2: Plate 5

Woodward, EC, 13: Plate 30

Woodward, EC, 13: Plate 30

Woodward, EC, 13: Plate 31

Smit, 8: Plate 67

Smit, 8: Plate 67

Stebbing, 20: Plate 25

Stebbing, 12: Plate 23

Stebbing, 12: Plate 24 
Alaotanais serratispinosus Alaotanais serratispinosus Ammodiscus gordialis Ammodiscus gordialis Amphihelia oculata Amphihelia ramea Amphihelia ramea Amphihelia ramea Amphistegina lessonii Androctonus (Prionurus) funestus

Androctonus funestus Androctonus funestus Androctonus occitanus Anisomelus luteus Anodonta Anodonta anatina Anomalina ammonoides Anomalina ariminensis Anomalina polymorpha Anomia cepa Anthelura abyssorum Anthelura elongata Anthura gracilis Antinoë funmarchica Antinoë mollis Antinous anthropophagorum Antipathes robillardi Apseudes anomalus Apseudes gracilis Apseudes grossimanus Apseudes latreillii Apseudes lunarifrons Apseudes obtusifrons Apseudes simplicirostris Apseudes spinosus Apseudes uncidigitatus Architeuthis princeps Argonauta hians Articulina conico-articulata Articulina conico-articulata Articulina sagra Articulina sulcata Artotrogus brevicaudatus Artotrogus brevicaudatus Aschemonella ramuliformis Asterope australis Asterope grisea Asterope lichenoides Asterope oculata Asterope quadrata Atriculina multilocularis Bairdia longisetosa
Stebbing, 12: Plate 23 Stebbing, 12: Plate 24 Unsigned, 20: Plate 46 West, 12: Plate 42 Erxleben, 8: Plate 45 DeWilde, 8: Plate 44 Erxleben, 8: Plate 45 Erxleben, 8: Plate 46 West, 12?: Piate 43

Stone, 11: P1ate 83 Lankester, 11: Plate 80 Stone, 11: Plate 81 Lankester, 11: Plate 80 Templeton, 2: Plate 5 Garner, 2: Plate 20 Garner, 2: Plate 18 West, 12: Plate 45 West, 12: Plate 45 Unsigned, 20: Plate 53 Garner, 2: Plate 20 Stebbing, 12: Plate 27 Stebbing, 12: Plate 25 Stebbing, 12: Plate 25 McIntosh, 9: Plate 72 McIntosh, 9: Plate 72 Robson, 20: Plate 32 Berjeau, 13: Plate 12 Stebbing, 12: Plate 21 Stebbing, 12: Plate 20 Stebbing, 12: Plate 19 Stebbing, 12: Plate 16 Stebbing, 12: Plate 17 Stebbing, 12: Plate 18 Stebbing, 12: Plate 18 Stebbing, 12: Plate 17 Stebbing, 12: Plate 21 Smit, 11: Plate 33 Owen, 2: Plate 21

Unsigned, 20: Plate 45

West, 12: Plate 40 Unsigned, 20: Plate 45 West, 12: Plate 40 Brady, 15: Plate 12 Brady, 15: Plate 13 Unsigned, 20: Plate 46 Brady, 14: Plate 43 Brady, 14: Plate 43 Brady, 16: Plate 23 Brady, 16: Plate 21 Brady, 14: Plate 45 West, 12: Plate 40 Brady, 16: Plate 25 
Bairdia oviformis

Balanophyllia cellulosa

Balanophyllia socialis

Bathycyathus atlanticus

Bathycyathus atlanticus

Bathycyathus minor

Beroë pileus

Bifarina mackinnonii

Biloculina depressa

Biloculina elongata

Biloculina irregularis

Biloculina ringens

Biloculina ringens var. denticulata

Biselenaria offa

Blastosmilia pourtalesi

Bodotria parva

Bodotria siamensis

Bodotria similis

Bodotria sublevis

Bolivina aenariensis

Bolivina dilatata

Bolivina limbata

Bolivina simpsoni

Bolivina textilarioides

Bornella digitata

Brotheas subnitens

Brotheas subnitens

Buccinum

Buccinum

Bulimina aculeata

Bulimina elegantissima

var. compressa

Bulimina inflata

Bulimina marginata

Bulimina squammigera

Buthus cyaneus

Byblis kallarthrus

Calathura brachiata

Caligus longicaudatus

Calyptraea (Calypeopsis) byronensis

Campylaspis orientalis

Campylaspis platyuropus

Cancer dentalus

Cancer dentatus

Cancer edwardsii

Cancer edwardsii

Cancer irroratus

Cancer irroratus

Cancer longipes

Cancer longipes

Cancer pagurus

Candone1la virescens

Candonopsis complanata
Brady, 10: Plate 63

Erxleben, 8: Plate 49

Erxleben, 8: Plate 43

DeWilde, 8: Plate 48

Erxleben, 10: Plate 45

Erxleben, 10: Plate 45

Grant, K.E., 1: Plate 2

Unsigned, 20: Plate 48

West, 12: Plate 40

West, 12: Plate 40

West, 12: Plate 40

West, 12: Plate 40

Unsigned, 20: Plate 40

Woodward, EC, 13: Plate 30

Erxleben, 10: Plate 45

Calman, 18: Plate 1

Calman, 18: Plate 1

Calman, 18: Plate 1

Calman, 18: Plate 1

West, 12: Plate 43

West, 12: Plate 43

Unsigned, 20: Plate 50

Unsigned, 20: Plate 49

West, 12: Plate 43

Williams, 5: Plate 33

Lankester, 11: Plate 80

Stone, 11: Plate 81

Geddes, 10: Plate 81

Geddes, 10: Plate 82

West, 12: Plate 43

Unsigned, 20: Plate 48

West, 12: Plate 43

West, 12: Plate 43

Unsigned, 20: Plate 48

Stone, 11: Plate 82

Stebbing, 12: Plate 38

Stebbing, 12: Plate 26

Brady, 15: Plate 12

Owen, 1: Plate 30

Calman, 18: Plate 35

Calman, 18: Plate 34

Westwood, 1: Plate 45

Sowerby, GB II, 1: P1. 47

Sowerby, GB II, 1: P1. 47

Westwood, 1: Plate 44

Sowerby, GB II, 1: P1. 47

Westwood, 1: Plate 46

Sowerby, GB II, 1: P1. 47

Westwood, 1: Plate 43

Sowerby, GB II, 1: P1. 47

Brady, 16: Plate 25

Brady, 16: Plate 25 
Cardium echinatum

Cardium edule

Caryophillia sequenzae

Caryophyllia abyssorum

Caryophyllia arcuata

Caryophyllia calveri

Caryophyllia carpenteri

Caryophyllia clavus var. borealis

Caryophyllia clavus var. elongata

Caryophyllia clavus var. epithecata

Caryophyllia clavus var. exserta

Caryophyllia clavus var. smithii

Caryophyllia cyathus var. alpha

Caryophylia cylindracea

Caryophyllia inskipi

Caryophyllia pourtalesi

Caryophyllia pourtalesi

Caryophyllia simplex

Caryophyllia vermiformis

Cassidulina (Orthoplecta) clavata

Cassidulina bradyi var. elongata

Cassidulina laevigata

Cassidulina subglobosa

Centromma thomsoni

Centropages discaudatus

Centropages pectinatus

Centrurus americanus

Centrurus hottentotus

Chelifer sp.

Chelifer albomaculatus

Chelifer antillarum

Chelifer argentinus

Chelifer bicolor

Chelifer canestrinii

Chelifer celerrimus

Chelifer celerrimus

Chelifer cervus

Chelifer communis

Chelifer crassimanus

Chelifer depressimanus

Chelifer ellingsenii

Chelifer elongatus

Chelifer imperator

Chelifer insignis

Chelifer intermedius

Chelifer longichelifer

Chelifer macrochelatus
Garner, 2: Plate 18

Garner, 2: Plate 18

DeWilde, 8: Plate 44

Erxleben, 8: Plate 40

Erxleben, 8: Plate 43

Erxleben, 10: Plate 43

Erxleben, 10: Plate 43

Dewilde, 8: Plate 48

DeWilde, 8: Plate 48

Dewilde, 8: Plate 48

DeWilde, 8: Plate 48

DeWilde, 8: Plate 48

Dewilde, 8: Plate 48

Erxleben, 8: Plate 40

Erxleben, 10: Flate 43

Erxleben, 10: Plate 43

Erxleben, 8: Plate 42

Erxleben, 10: Plate 43

Erxleben, 8: Plate 40

Unsigned, 20: Plate 50

Unsigned, 20: Plate 50

West, 12: Plate 43

West, 12: Plate 43

Brady, 15: Plate 13

Brady, 15: Plate 10

Brady, 15: Plate 9

Stone, 11: Plate 82

Stone, 11: Plate 82

With, 18: Plate 31

With, 18: Plate 30

With, 18: Plate 30

With, 18: Plate 31

With, 18: Plate 30

With, 18: Plate 29

With, 18: Plate 30

With, 18: Plate 31

With, 18: Plate 31

With, 18: Plate 31

With, 18: Plate 30

With, 18: Plate 31

With, 18: Plate 31

With, 18: Plate 31

With, 18: Plate 29

With, 18: Plate 29

With, 18: Plate 31

With, 18: Plate 29

With, 18: Plate 31 
Chelifer meinertii

Chelifer michaelsenii

Chelifer nidifactor

Chelifer nitidimanus

Chelifer nitidus

Chelifer nobilis

Chelifer nodulimanus

Chelifer plumosus

Chelifer rex

Chelifer rudis

Chelifer rufus

Chelifer satanas

Chelifer segmentidentatus

Chelifer similis

Chelifer subgracilis

Chelifer subovatus

Chelifer subrobustus

Chelifer subrotundatus

Chelifer subrudis

Chloëia fucata

Chromodoris zebrina

Chronos sublimis

Chrysalidina dimorpha

Cidaris curvatispinis

Clabulina cylindrica

Cladocarpus formosus

Clausocalanus furcatus

Clavagella lata

Clavularia australiensis var. A

Clavularia australiensis var. B

Clavularia celebensis

Clavularia flava

Clavularia garciae

Clavularia garciae

Clavularia ramosa

Clavularia reptans

Clavularia viridis

Clavularia viridis

Clavulina angularis var. difformis

Clavulina communis

Clavulina communis

Clavulina parisiensis

Codonocera cruenta

Colurostylis pseudocuma

Conchaecissa cucullata

Conescharellina clithridiata

Corbula striata

Cornuspira charoides

Cornuspira involvens

Cranchia scabra

Cribrilina vinei
With, 18: Plate 30

With, 18: Plate 30

With, 18: Plate 31

With, 18: Plate 30

With, 18: Plate 31

With, 18: Plate 29

With, 18: Plate 31

With, 18: Plate 30

With, 18: Plate 29

With, 18: Plate 30

With, 18: Plate 29

With, 18: Plate 29

With, 18: Plate 29

With, 18: Plate 31

With, 18: Plate 30

With, 18: Plate 31

With, 18: Plate 30

With, 18: Plate 30

With, 18: Plate 30

McIntosh, 3: Plate 71

Williams, 5: Plate 29

Robson, 20: Plate 32

Unsigned, 20: Plate 47

Berjeau, 13: Plate 38

Unsigned, 20: Plate 48

Smit, 8: Plate 68

Brady, 15: Plate 9

Owen, 1: Plate 30

Hickson, SJ, 13: Plate 50

Hickson, SJ, 13: Plate 50

King, 13: Plate 48

Hickson, SJ, 13: Plate 50

Hickson, SJ, 13: Plate 50

King, 13: Plate 46

Hickson, SJ, 13: Plate 50

King, 13: Plate 47

Hickson, AW, 13: Plate 49

Hickson, SJ, 13: Plate 50

Unsigned, 20: Plate 48

Unsigned, 20: Plate 48

West, 12: Plate 42

West, 12: Plate 42

Brady, 16: Plate 22

Calman, 18: Plate 36

Brady, 16: Plate 24

Woodward, EC, 13: Plate 31

Garner, 2: Plate 18

Unsigned, 20: Plate 46

West, 12: Plate 40

Owen, 2: Plate 21

Woodward, EC, 13: Plate 30 
Cristellaria

Cristellaria calcar

Cristellaria cassis

Cristellaria crepidula

Cristellaria cultrata

Cristellaria rotulata

Cristellaria variabilis

Cumella clavicauda

Cumella forficula

Cumella hispida

Cumella laevis

Cumella leptopus

Cumella serrata

Cyathura carinata

Cyclas rivicola

Cyclaspis biplicata

Cyclaspis cingulata

Cyclaspis elegans

Cyclaspis levis

Cyclaspis longipes

Cyclaspis similis

Cyclaspis thomsoni

Cyclaspis triplicata

Cyclaspis unicornis

Cyclaspis uniplicata

Cyclasterope brevis

Cyclasterope fascigera

Cyclasterope hendersoni

Cyclasterope orbicularis

Cyclasterope ovulum

Cyclasterope similis

Cyclasterope tenera

Cyclasterope zealandica

Cyclops ewarti

Cymbalopora milletti

Cymbalopora poeyi

Cypretta sarsi

Cypridina(?) armata

Cypridina(?) squamosa

Cypridina bairdi

Cypridina castanea

Cypridina danae

Cypridina foveolata

Cypridina granulosa

Cypridina insolita

Cypridina punctata

Cypridinodes favus

Cypridopsis marmorata

Cyprinotus

dentato-marginatus

Cyprinotus flavescens

Cyprinotus fragilis

Cyprinotus fragilis

Cypris flexilis

Cypris laetevirens
West, 12: Plate 44 West, 12: Plate 44 West, 12: Plate 44 West, 12: Plate 44 West, 12: Plate 44 West, 12: Plate 44 West, 12: Plate 44 Calman, 18: Plate 32 Calman, 18: Plate 32 Calman, 18: Plate 32 Calman, 18: Plate 32 Calman, 18: Plate 32 Calman, 18: Plate 32 Stebbing, 12: Plate 27 Garner, 2: Plate 2U Calman, 18: Plate 3 Calman, 18: Plate 4 Calman, 18: Plate 2 Calman, 18: Plate 5 Calman, 18: Plate 5 Calman, 18: Plate 3 Calman, 18: Plate 5 Calman, 18: Plate 3 Calman, 18: Plate 5 Calman, 18: Plate 4 Brady, 16: Plate 24 Brady, 16: Plate 21 Brady, 14: Plate 15 Brady, 14: Plate 15 Brady, 14: Plate 43 Brady, 16: Plate 23 Brady, 14: Plate 44 Brady, 14: Plate 43 Brady, 15: Plate 10 Unsigned, 20: Plate 51 West, 12: Plate 46 Brady, 16: Plate 25 Brady, 14: Plate 15 Brady, 14: Plate 16 Brady, 14: Plate 16 Brady, 14: Plate 16 Brady, 14: Plate 16 Brady, 16: Plate 22 Brady, 16: Plate 21 Brady, 16: Plate 22 Brady, 14: Plate 16 Brady, 16: Plate 22 Brady, 16: Plate 23

Brady, 16: Plate 23 Brady, 14: Plate 46 Brady, 16: Plate 23 Brady, 16: Plate 25 Brady, 16: Plate 23 Brady, 16: Plate 23 
Cypris virens

Cypris viridis

Cythere acuticosta

Cythere belgica

Cythere brunnea

Cythere cicatricosa

Cythere cornuta

Cythere cribrosa?

Cythere dawsoni?

Cythere ellipsoidea

Cythere innominata

Cythere jonesii

Cythere jurinei

Cythere latimarginata

Cythere limicola

Cythere macropora

Cythere macropora

Cythere mucronata

Cythere oedichilus

Cythere petrosa

Cythere plicata

Cythere plicatula

Cythere polytrema

Cythere scabropapulosa

Cythere sicula

Cythere subcoronata

Cythere tarentina

Cythere trapezia

Cythere truncula

Cythere wetherellii

Cythere woodiana

Cytherella eburnea

Cytherella elliptica

Cytherella nodosa

Cytherella parallela

Cytheridea cypridioides

Cytheridea milleri

Cytheridea papillosa var.

Cytheridea pinguis

Cytherideis (?)

lithodomoides

Cytherideis recta

Cytheropteron gradatum

Cytheropteron intermedium

Cytheropteron latissimum

Cytheropteron pipistrella

Cytherura broeckiana

Dactylopus hanseni

Dactylopus tisboides

Dasylepis asperrima

Desmophyllum crista-galli

Diastylis fistularis

Diastylis koreana

Diastylopsis crassior

Diastylopsis elongata
Brady, 16: Plate 23

Brady, 14: Plate 45

Brady, 10: Plate 66

Brady, 10: Plate 65

Brady, 14: Plate 47

Brady, 10: Plate 64

Brady, 10: Plate 66

Brady, 10: Plate 64

Brady, 10: Plate 66

Brady, 10: Plate 65

Brady, 14: Plate 46

Brady, 10: Plate 67

Brady, 10: Plate 65

Brady, 10: Plate 64

Brady, 10: Plate 64

Brady, 10: Plate 66

Brady, 10: Plate 67

Brady, 10: Plate 67

Brady, 10: Plate 64

Brady, 10: Plate 64

Brady, 10: Plate 65

Brady, 10: Plate 64

Brady, 10: Plate 66

Brady, 10: Plate 66

Brady, 16: Plate 25

Brady, 10: Plate 67

Brady, 10: Plate 63

Brady, 10: Plate 66

Brady, 14: Plate 47

Brady, 10: Plate 64

Brady, 10: Plate 65

Brady, 14: Plate 46

Brady, 10: Plate 62

Brady, 10: Plate 62

Brady, 10: Plate 62

Brady, 10: Plate 69

Brady, 10: Plate 62

Brady, 10: Plate 62

Brady, 10: Plate 62

Brady, 10: Plate 63

Brady, 10: Plate 63

Brady, 10: Plate 69

Brady, 10: Plate 69

Brady, 10: Plate 69

Brady, 10: Plate 69

Brady, 10: Plate 69

Brady, 15: Plate 11

Brady, 15: Plate 12

McIntosh, 9: Plate 67

Dewilde, 8: Plate 41

Calman, 18: Plate 37

Calman, 18: Plate 37

Calman, 18: Plate 37

Calman, 18: Plate 37 
Diphasia coronifera

Diplopteron insigne

Diplotis hyalina?

Discorbina bertheloti

Discorbina globosa

Discorbina globularis

Discorbina globularis

Discorbina orbicularis

Discorbina patelliformis

Discorbina

polys tomelloides

Discorbina pustulata

Discorbina reniformis

Discorbina valvulata

var. granulosa

Discorbina vesicularis

Distoma

Distoma clavatum

Doridopsis atromaculata

Doridopsis clavulata

Doridopsis fusca

Doridopsis gemmacea

Doridops is miniata

Doridopsis nigra

Doridopsis nigra var. a

Doridopsis nigra var. b

Doridops is punctata

Doridopsis pustulosa

Doridopsis rubra

Doridopsis tuberculosa

Doris apiculata

Doris areolata

Doris carinata

Doris castanea

Doris concinna

Doris ellioti

Doris formosa

Doris fragilis

Doris funebris

Doris osseosa

Doris pardalis

Doris rusticata

Doris striata

Doris tristis

Doris villosa

Ectinosoma australe

Enipo kinbergi

Enoploteuthis cookii

Enoploteuthis cookii

Enoploteuthis cookii

Enoploteuthis cookii

Entalophora tergemina

Entomolepis ovalis

Eocuma lata

Eocuma longicornis
Smit, 8: Plate 66

Smit, 8: Plate 68

Garner, 2: Plate 20

West, 12: Plate 46

Unsigned, 20: Plate 52

Unsigned, 20: Plate 51

West, 12: Plate 46

West, 12: Plate 46

Unsigned, 20: Plate 52

Unsigned, 20: Plate 52

Unsigned, 20: Plate 52

Unsigned, 20: Plate 52

Unsigned, 20: Plate 52

Unsigned, 20: Plate 52

Garner, 2: Plate 20

Owen, 1: Plate 41

Williams, 5: Plate 31

Williams, 5: Plate 31

Williams, 5: Plate 31

Williams, 5: Plate 31

Williams, 5: Plate 31

Williams, 5: Plate 31

Williams, 5: Plate 31

Williams, 5: Plate 31

Williams, 5: Plate 31

Williams, 5: Plate 31

Williams, 5: Plate 31

Williams, 5: Plate 29

Williams, 5: Plate 30

Williams, 5: Plate 30

Williams, 5: Plate 29

Williams, 5: Plate 28

Williams, 5: Plate 28

Williams, 5: Plate 28

Williams, 5: Plate 29

Williams, 5: Plate 28

Williams, 5: Plate 30

Williams, 5: Plate 28

Williams, 5: Plate 28

Williams, 5: Plate 30

Williams, 5: Plate 29

Williams, 5: Plate 30

Williams, 5: Plate 33

Brady, 15: Plate 10

McIntosh, 9: Plate 70

Smit, 11: Plate 30

Smit, 11: Plate 31

Smit, 11: Plate 32

Smit, 11: Plate 33

Woodward, EC, 13: Plate 32

Brady, 15: Plate 13

Calman, 18: Plate 6

Calman, 18: Plate 6 
Eocuma producta

Eocuma stellifera

Eolis militaris

Eolis ocellata

Eolis unilineata

Epialtus marginatus

Epialtus marginatus

Euconchaecia chierchiae

Eudorellopsis resimus

Eunoa hispanica

Eunoa nodosa

Eupanthalis kinbergi

Eupathistoma natans

Euphrosyne lanceolata

Euplectella aspergillum

Eurypylus petrosus

Euscorpius italicus

Euscorpius italicus

Euscorpius italicus

Eusthenelais hibernica

Evarne impar

Evarne johnstoni

Fischerina helix

Flabellum distinctum

Flabellum laciniatum

Flabellum minus

Flava crassicornis

Fungia symmetrica

Gaudryina filiformis

Gaudryina pupoides

Gaudryina pupoides var. chilostoma

Gaudryina scabra

Gemmulatrochus simplex

Gerardia savalia

Glaucus forsteri

Globigerina bulloides

Globigerina conglobata

Globigerina cretacea

Globigerina rubra

Gnathia cristatipes

Gnathia schistifrons

Goniodoris aspersa

Goniodoris citrina

Goniodoris modesta

Guynia annulata

Gynodiastylis bicristata

Gynodiastylis carinata

Gynodiastylis costata

Gynodiastylis laevis

Gypsina globulus

Gypsina Inhaerens

Gypsina rubra

Haddonia torresiensis

Halicornaria ramulifera
Calman, 18: Plate 6

Calman, 18: Plate 6

Williams, 5: Plate 33

Williams, 5: Plate 33

Williams, 5: Plate 33

Westwood, 2: Plate 11

Westwood, 2: Plate 13

Brady, 16: Plate 24

Calman, 18: Plate 8

McIntosh, 9: Plate 71

McIntosh, 9: Plate 67

McIntosh, 9: Plate 72

Brady, 14: Plate 44

McIntosh, 9: Plate 71

Sowerby, G.B., Jr. 3: Plate 13

Brady, 14: Plate 16

Stone, 11: Plate 81

Stone, 11: Plate 82

Stone, 11: Plate 83

McIntosh, 9: Plate 73

McIntosh, 9: Plate 70

McIntosh, 9: Plate 71

Unsigned, 20: Plate 46

Erxleben, 8: Plate 39

Erxleben, 8: Plate 39

Erxleben, 10: Plate 45

Brady, 15: Plate 10

Erxleben, 8: Plate 49

West, 12: Plate 42

West, 12: Plate 42

West, 12: Plate 42

Unsigned, 20: Plate 48

Erxleben, 10: Plate 45

Berjeau, 13: Plate 11

Williams, 5: Plate 33

West, 12: Plate 45

West, 12: Plate 45

Unsigned, 20: Plate 51

West, 12: Plate 45

Stebbing, 20: Plate 24

Stebbing, 20: Plate 24

Williams, 5: Plate 33

Williams, 5: Plate 32

Williams, 5: Plate 28

DeWilde, 8: Plate 47

Calman, 18: Plate 36

Calman, 18: Plate 35

Calman, 18: Plate 36

Calman, 18: Plate 35

West, 12: Plate 46

West, 12: Plate 41

Unsigned, 20: Plate 53

Unsigned, 20: Plate 46

Smit, 8: Plate 67 
Haplophragmium canariense Haplophragmium compressum Haplophragmium latidorsatum

Haplophragmium nanum Harmothoë antilopes Harmothoë areolata Harmothoë haliaeeti Harmothoë imbricata Harmothoë lunulata Harmothoë macleodi Harmothoë marphysae Harmothoë sibbaldii Harmothoë zetlandica Harmothoë zetlandica Harpacticus glaber Hauerina fragilissima Hemileucon comes Hemileucon uniplicatus Herbstia edwardsii Hermadion assimile Heteroleucon akaroëns is Heteropora glandiformis Hippocrepina oviformis Hormosina globulifera Hornera farehamensis Hyas edwardsii Hyperammina ramosa Hyssura producta Idmonea bialternata Idmonea coronopus Idmonea giebeli Idmonea seriatopora Idmonea seriatopora Iridia diaphana Kalinga ornata Kenia desjardiniana Labidocera cervi

Lafoëa halecioides

Lagena clavata

Lagena lagenoides

Lagena lineata

Lagena marginata

Lagena marginato-perforata

Lagena melo

Lagena melo

Lagena orbignyana

Lagena orbignyana var. Kerimbatica

Lagena orbignyana var. walleriana

Lagena striata Lagena sulcata Lagena sulcata Lagisca jeffreysi
West, 12: Plate 41 Unsigned, 20: Plate 46

West, 12: Plate 41 West, 12: Plate 41 McIntosh, 9: Plate 69 McIntosh, 9: Plate 68 McIntosh, 9: Plate 69 McIntosh, 9: Plate 68 McIntosh, 9: Plate 69 McIntosh, 9: Plate 69 McIntosh, 9: Plate 69 McIntosh, 9: Plate 68 MicIntosh, 9: Plate 68 McIntosh, 9: Plate 69 Brady, 15: Plate 12 Unsigned, 20: Plate 46 Calman, 18: Plate 9 Calman, 18: Plate 9 Westwood, 2: Plate 9 McIntosh, 9: Plate 70 Calman, 18: Plate 8 Woodward, EC, 13: Plate 32 Unsigned, 20: Plate 46 Unsigned, 20: Plate 46 Woodward, EC, 13: Plate 32 Westwood, 2: Plate 9 West, 12: Plate 41 Stebbing, 12: Plate 25 Woodward, EC, 13: Plate 32 Woodward, EC, 13: Plate 32 Woodward, EC, 13: Plate 32 Woodward, EC, 13: Plate 32 Woodward, EC, 13: Plate 32 Rhodes, 20: Plate 36 Williams, 5: Plate 32 Templeton, 2: Plate 5 Brady, 15: Plate 10 Smit, 8: Plate 66 Unsigned, 20: Plate 50 West, 12: Plate 44 West, 12: Plate 44 West, 12: Plate 44 Unsigned, 20: Plate 50 West, 12: Plate 44 West, 12: Plate 44 West, 12: Plate 44

Unsigned, 20: Plate 50

Unsigned, 20: Plate 50 West, 12: Plate 44 West, 12: Plate 44 West, 12: Plate 44 McIntosh, 9: Plate 71 
Lagisca jeffreysi

Lagisca propinqua

Laophonte meinerti

Leanira hystricis

Leanira yhleni

Lepidasthenia blainvillii

Lepidasthenia longissima

Lepralia lonsdalei

Leucon(?) heterostylis

Libinia rostrata

Lichenopora

Limulus

Limulus

Limulus

Limulus

Limulus

Linguatula taenioides

Lingula audebardii

Lingula semen

Loligo

Loligo

Loligo laticeps

Loligopsis guttata

Loligopsis ocellata

Loligopsis ocellata

Lophohelia prolifera

Lophohelia prolifera var. gracilis

Loxoconcha bitruncata

Loxoconcha grateloupiana

Loxoconcha latissima

Loxoconcha punctata

Loxoconcha variolata

Lunulites transiens

Lunulites transiens

Mactra stultorum

Madrella ferruginosa

Malmgrenia andreapolis

Malmgrenia castanea

Malmgrenia castanea

Massilina alveoliniformis

Massilina macilenta

Massilina secans

Massilina secans var. reticulata

Massilina secans var rugosa

Massilina secans var. tenuistriata

Melibaea viridis

Melibe fimbriata

Membranipora buski

Membranipora crassomuralis

Membranipora disjuncta

Membranipora eocena
McIntosh, 9: Plate 73

McIntosh, 9: Plate 67

Brady, 15: Plate 11

McIntosh, 9: Plate 73

McIntosh, 9: Plate 73

McIntosh, 9: Plate 72

McIntosh, 9: Plate 72

Woodward, EC, 13: Plate 31

Calman, 18: Plate 8

Westwood, 2: Plate $\delta$

Woodward, EC, 13: Plate 32

Benham, 11: Plate 72

Benham, 11: Plate 73

Benham, 11: Plate 74

Benham, 11: Plate 75

Benham, 11: Plate 76

Owen, 1: Plate 41

Owen, 1: Plate 23

Owen, 1: Plate 23

Geddes, 10: Plate 80

Geddes, 10: Plate 81

Owen, 2: Plate 21

Grant, R.E., 1: Plate 2

Scharf, H., 11: Plate 27

Smit, 11: Plate 26

DeWilde, 8: Plate 44

Erxleben, 8: Plate 42

Brady, 10: Plate 68

Brady, 10: Plate 68

Brady, 10: Plate 68

Brady, 14: Plate 46

Brady, 10: Plate 68

Woodward, EC, 13: Plate 29

Woodward, EC, 13: Plate 3C

Garner, 2: Plate 18

Williams, 5: Plate 33

McIntosh, 9: Plate 67

McIntosh, 9: Plate 67

McIntosh, 9: Plate 68

Unsigned, 20: Plate 45

Unsigned, 20: Plate 45

Unsigned, 20: Plate 44

Unsigned, 20: Plate 45

Unsigned, 20: Plate 45

Unsigned, 20: Plate 44

Williams, 5: Plate 33

Williams, 5: Plate 33

Woodward, EC, 13: Plate 29

Woodward, EC, 13: Plate 29

Woodward, EC, 13: Plate 29

Woodward, EC, 13: Plate 29 
Membranipora tenuimuralis Membranipora virguliformis Meniscopora bigibbera Microchaeta rappi Microchaeta rappi Micropora cribiformis Microrhynchus depressus Microrhynchus gibbosus Miliolina agglutinans Miliolina auberiana var. stenostoma

Miliolina bertheliniana Miliolina bicornis Miliolina bicostata Miliolina circularis var. cribrostoma Miliolina circularis var. sublineata Miliolina costata Miliolina crassa Miliolina cultrata Miliolina cuvieriana Miliolina durrandii Miliolina excisa Miliolina exsculpta Miliolina funafutiensis Miliolina kerimbatica Miliolina limbata Miliolina oblonga Miliolina parkeri Miliolina pygmaea Miliolina reticulata Miliolina rotunda Miliolina sclerotica Miliolina scrobiculata Miliolina seminulum Miliolina seminulum Miliolina striata Miliolina terquemiana Miliolina transversestriata Miliolina tricarinata Miliolina tricarinata var. plicata

Miliolina tricarinata var. plicata

Miliolina tricarinata var. serrata

Miliolina triquetra Miliolina undosa Miliolina undulata Mimosina echinata Mimosina hystrix Mimosina rimosa Mithrax denticulatus
Woodward, EC, 13: Plate 29 Woodward, EC, 13: Plate 29 Woodward, EC, 13: Plate 31 Beddard, 12: Plate 14 Beddard, 12: Plate 15 Woodward, EC, 13: Plate 30 Westwood, 2: Plate 8 Westwood, 2: Plate 8 West, 12: Plate 40

Unsigned, 20: Plate 42 Unsigned, 20: Plate 41 West, 12: Plate 40 Unsigned, 20: Plate 42

Unsigned, 20: Plate 41

Unsigned, 20: P1ate 41 Unsigned, 20: Plate 44 Unsigned, 20: Plate 42 Unsigned, 20: Plate 42 Unsigned, 20: Plate 42 Unsigned, 20: Plate 42 West, 12: Plate 40

Unsigned, 20: Plate 42 Unsigned, 20: Plate 42 Unsigned, 20: Plate 43 Unsigned, 20: Plate 44 West, 12: Plate 40 Unsigned, 20: Plate 43 West, 12: Plate 40 Unsigned, 20: Plate 43 Unsigned, 20: Plate 42 Unsigned, 20: Plate 44 Unsigned, 20: Plate 44 Unsigned, 20: Plate 42 West, 12: Plate 40

Unsigned, 20: Plate 44 Unsigned, 20: Plate 41

Unsigned, 20: Plate 42 West, 12: Plate 40

Unsigned, 20: Plate 41

Unsigned, 20: Plate 41

Unsigned, 20: Plate 41 Unsigned, 20: Plate 44 Unsigned, 20: Plate 43 Unsigned, 20: Plate 43 Unsigned, 20: Plate 50 Unsigned, 20: Plate 50 Unsigned, 20: Plate 50 Westwood, 2: Plate 11 
Mithrax nodosus

Mithrax pygmaeus

Mithrax rostratus

Mithrax ursus

Mucronella angustoaecium

Mytilus edulis

Nannastacus agnatus

Nannastacus gibbosus

Nannastacus lepturus

Nannastacus minor

Nannastacus reptans

Nannastacus tardus

Nannastacus zimmeri

Nautilus pompilius

Nautilus pompilius

Nautilus pompilius

Nautilus pompilius

Nereis phosphorescens

Nodosaria (D.) mucronata

Nodosaria (D.) obliqua

Nodosaria calomorpha

Nodosaria hispida

Nodosaria pyrula

Nodosaria scalaris

Nodosaria scalaris

Nodosaria spinulosa

Nonionina depressula

Nonionina exponens

Nonionina scapha

Nonionina umbilicatula

Notamia wetherelli

Nouria compressa

Nouria harrisii

Nouria polymorphinoides

Nubecularia lucifuga var. decorata

Nubecularia tubulosa

Nucula nucleus

Nummulella?

Octopus semipalmatus

Ommastrephes ensifer

Onychocella magnoaperta

Onychoteuthis raptor

Ophthalmidium inconstans

Orbicula cumingii

Orbicula lamellosa

Orbicula strigata

Orbitulipora petiolus

Orbulina universa

Othonia quinque-dentata

Othonia sex-dentata

Pachychalina variabilis

Pachychalina variabilis

Pandora inaequivalvis

Papuina lituus
Westwood, 2: Plate 11
Westwood, 2: Plate 11
Westwood, 2: Plate 10
Westwood, 2: Plate 10
Woodward, EC, 13: Plate 31
Garner, 2: Plate 20
Calman, 18: Plate 34
Calman, 18: Plate 33
Calman, 18: Plate 33
Calman, 18: Plate 34
Calman, 18: Plate 33
Calman, 18: Plate 34
Calman, 18: Plate 33
Van der Hoeven, $4:$ Plate 5
Van der Hoeven, $4:$ Plate 6
Van der Hoeven, $4:$ Plate 7
Van der Hoeven, $4:$ Plate 8
Garner, 2: Plate 20
West, 12: Plate 44
West, 12: Plate 44
West, 12: Plate 44
West, 12: Plate 44
West, 12: Plate 44
West, 12: Plate 44
West, 12: Plate 44
Unsigned, 20: P1ate 50
West, 12: Plate 43
West, 12: Plate 43
West, 12: Plate 43
West, 12: Plate 43
Woodward
Eh $13:$
Pata

Woodward, EC, 13: Plate 29

Rhodes, 20: Plate 37

Rhodes, 20: Plate 37

Rhodes, 20: Plate 37

Unsigned, 20: Plate 40

Unsigned, 20: Plate 40

Garner, 2: Plate 18

Garner, 2: Plate 20

Cwen, 2: Plate 21

Erxleben, 11: Plate 28

Woodward, EC, 13: Plate 30

Smit, 11: Plate 29

West, 12: Plate 40

Owen, 1: Plate 23

Owen, 1: Plate 23

Owen, 1: Plate 23

Woodward, EC, 13: Plate 31

West, 12: Plate 45

Westwood, 2: Plate 12

Westwood, 2: Plate 12

Mintern Bros, 12: Plate 58

Mintern Bros, 12: Plate 60

Garner, 2: Plate 18

Robson, 20: Plate 32 
Paracalanus parvus

Paraconchaecia oblonga

Paracyathus africanus

Paracyathus agassizi

Paracyathus costatus

Paracyathus humilis

Paracyathus inornatus

Paracyathus insignis

Paracyathus monilis

Paracyathus striatus

Paracyathus striatus

Paracypris polita

Paradoxostoma ensiforme

Paraleucon suteri

Paranthura nigro-punctata

Paranthura tenuis

Paurocope robusta

Pavonina flabelliformis

Pecten maximus

Pecten maximus

Pecten opercularis

Pecten opercularis

Pelia pulchella

Peltidium novae-zealandiae

Peltidium novae-zealandiae

Peneroplis pertusus

Pericera heptacantha

Pericera ovata

Pericera villosa

Pherusa caerulea

Philomedes agilis

Philomedes corrugata

Philomedes debilis

Philomedes flexilis

Philomedes flexilis

Philomedes sculpta

Philomedes sordida

Phroso gracilis

Phyllantinoë mollis

Phyllobranchus orientalis

Piratesa nigio-annulota

Pisa aculeata

Pisa spinipes

Placopsilina cenomana

Planispirina auriculata

Planispirina communis

Planispirina exigua

Planispirina sigmoidea

Planorbulina acervalis

Planorbulina mediterranensis

Plectoteuthis grandis

Plectoteuthis grandis

Pleoschisma moroides

Pliobothrus symmetricus
Brady, 15: Plate 9

Brady, 14: Plate 17

Erxleben, 10: Plate 44

Erxleben, 8: Plate 43

Erxleben, 10: Plate 44

Erxleben, 10: Plate 44

Erxleben, 10: Plate 44

Erxleben, 10: Plate 44

Erxleben, 10: Plate 44

Erxleben, 10: Plate 44

Erxleben, 8: Plate 43

Brady, 10: Plate 63

Brady, 10: Plate 64

Calman, 18: Plate 9

Stebbing, 12: Plate 26

Stebbing, 12: Plate 27

Brady, 15: Plate 13

Unsigned, 20: Plate 48

Garner, 2: Plate 19

Garner, 2: Plate 20

Garner, 2: Plate 19

Garner, 2: Plate 20

Westwood, 2: Plate 9

Brady, 15: Plate 12

Brady, 15: Plate 9

West, 12: Plate 42

Westwood, 2: Plate 12

Westwood, 2: Plate 12

Westwood, 2: Plate 12

Stebbing, 12: Plate 39

Brady, 14: Plate 16

Brady, 14: Plate 16

Brady, 16: Plate 21

Brady, 14: Plate 44

Brady, 14: Plate 45

Brady, 14: Plate 44

Brady, 16: Plate 24

Brady, 15: Plate 11

McIntosh, 9: Plate 72

Williams, 5: Plate 33

Templeton, 2: Plate 5

Westwood, 2: Plate 9

Westwood, 2: Plate 9

West, 12: Plate 42

Unsigned, 20: Plate 46

Unsigned, 20: Plate 46

West, 12: Plate 40

West, 12: Plate 40

West, 12: Plate 46

West, 12: Plate 45

Erxlében, 11: Plate 34

Erxleben, 11: Plate 35

Brady, 14: Plate 17

Erxleben, 8: Plate 49 
Plocamophorus ceylonicus

Podoceropsis palmatus

Podocerus cumbrensis

Polymorphia complexa

Polymorphina lactea

Polynoë floccosa

Polys tomella

Polystomella milletti

Polystomella

striatopunctata

Pontocypris faba

Pontocypris propinqua

Prionurus funestus

Psammobia florida

Psammolyce herminiae

Pseudoconchaecia serrulata

Pullenia quinqueloba

Pullenia sphaeroides

Pulvinulina elegans

Pulvinulina lateralis

Pulvinulina menardii

Pulvinulina micheliniana

Pulvinulina oblonga

Pulvinulina partschiana

Pulvinulina schreibersii

Pyrocypris americana

Reophax fusiformis

Reophax pilulifera

Reophax scorpiurus

Rhabdogonium tricarinatum

Rhabdosoma brachyteles

Rhabdosoma piratum

Rhapidoscene conica

Rhizotrochus affinis

Rhodia pyriformis

Rossia palpebrosa

Rotalia erinacea

Rotalia murrayi

Rotalia venusta

Sabinotrochus apertus

Sagrina dimorpha

Sagrina striata

Sagrina tessellata

Sagrina virgula

Sarsiella hanseni

Sarsiella hispida

Sarsiella ornithoides

Sarsiella robusta

Sarsiella sculpta

Sarsiella simplex

Schizoporella magnoaperta

Schizoporella magnoincisa

Schizotrema bifrons

Schizotrema depressum

Schizotrema sordidum
Williams, 5: Plate 32

Stebbing, 13: Plate 6

Stebbing, 13: Plate 6

Unsigned, 20: Plate 51

West, 12: Plate 44

McIntosh, 9: Plate 68

West, 12: Plate 43

Unsigned, 20: Plate 53

West, 12: Plate 43

Brady, 10: Plate 63

Brady, 10: Plate 63

Stone, 11: Plate 82

Garner, 2: Plate 18

McIntosh, 9: Plate 73

Brady, 14: Plate 17

West, 12: Plate 43

West, 12: Plate 43

West, 12: Plate 46

Unsigned, 20: Plate 53

West, 12: Plate 46

West, 12: Plate 46

West, 12: Plate 46

Unsigned, 20: Plate 53

West, 12: Plate 46

Brady, 16: Plate 21

West, 12: Plate 41

West, 12: Plate 41

West, 12: Plate 41

West, 12: Plate 45

Stebbing, 13: Plate 55

Stebbing, 13: Plate 55

Unsigned, 20: Plate 46

Dewilde, 8: Plate 47

Westwood, 2: Plate 9

Owen, 2: Plate 21

Unsigned, 20: Plate 53

Unsigned, 20: Plate 53

Unsigned, 20: Plate 53

DeWilde, 8: Plate 41

West, 12: Plate 45

Unsigned, 20: Plate 51

Unsigned, 20: Plate 51

Unsigned, 20: Plate 51

Brady, 14: Plate 45

Brady, 14: Plate 45

Brady, 16: Plate 23

Brady, 14: Plate 17

Brady, 14: Plate 17

Brady, 14: Plate 17

Woodward, EC, 13: Plate 30 Woodward, EC, 13: Plate 30

Calman, 18: Plate 34

Calman, 18: Plate 34

Calman, 18: Plate 34 
Scina acanthodes

Scina concors

Scina oedicarpus

Scina rattrayi

Scina similis

Scina stenopus

Scina uncipes

Scorpio (Androctonus)

Scorpio (Androctonus)

Scorpio (Buthus)

Scorpio (Buthus)

Scorpio (Buthus)

Scorpio (Buthus) cyaneus

Scorpio (Buthus) cyaneus

Scorpio (Italicus)

Scorpio italicus

Scutellidium plumosum

Scyllaea marmorata

Scyllaea viridis

Sepia officinalis

Sepia palmata

Sepia palmata

Sepiola stenodactyla

Sepiola vulgaris

Sepioteuthis

Sepioteuthis brevis

Sertularella gayi var. robusta

Sigalion buskii

Sigmoilina edwardsi

Sigmoilina ovata

Siphonochalina ceratosa

Siphonochalina ceratosa

Siphonochalina procumbens

Siphonochalina procumbens

Siphonochalina spiculosa

Siphonochalina spiculosa

Siren lacertinal

Smittia tubularis

Solen ensis

Solenosmilia variabilis

Sophrosyne robertsoni

Sphaeroidina bulloides

Sphaeroidina corticata

Sphenotrochus intermedius

Sphyrapus malleolus

Sphyrapus tudes

Spinosella maxima

Spinosella plicifera

Spinosella plicifera

Spinosella sororia

Spinosella sororia

Spinosella sororia

var. dilata
Stebbing, 13: Plate 51

Stebbing, 13: Plate 53

Stebbing, 13: Plate 52

Stebbing, 13: Flate 53

Stebbing, 13: Plate 54

Stebbing, 13: Plate 52

Stebbing, 13: Plate 54

Beck, 11: Plate 77

Beck, 11: Plate 78

Beck, 11: Plate 77

Beck, 11: Plate 78

Beck, 11: Plate 79

Lankester, 11: Plate 80

Stone, 11: Plate 81

Beck, 11: Plate 79

Stone, 11: Plate 81

Brady, 15: Plate 12

Williams, 5: Plate 33

Williams, 5: Plate 33

Owen, 2: Plate 21

Smit, 11: Plate 24

Smit, 11: Plate 25

Grant, R.E., 1: Plate 11

Grant, R.E., 1: Plate 11

Owen, 2: Plate 21

Smit, 11: Plate 26

Smit, 8: Plate 66

McIntosh, 9: Plate 70

Unsigned, 20: Plate 45

Unsigned, 20: Plate 45

Mintern Bros, 12: Plate 58

Mintern Bros, 12: Plate 62

Mintern Bros, 12: Plate 58

Mintern Bros, 12: Plate 62

Mintern Bros, 12: Plate 58

Mintern Bros, 12: Plate 62

Owen, 1: Plate 31

Woodward, EC, 13: Plate 32

Garner, 2: Plate 18

Erxleben, 8: Plate 42

Stebbing, 13: Plate 5

West, 12: Plate 45

Unsigned, 20: Plate 51

DeWilde, 8: Plate 41

Stebbing, 12: Plate 22

Stebbing, 12: Plate 22

Mintern Bros 12: Plate 61

Mintern Bros, 12: Plate 58

Mintern Bros, 12: Plate 60

Mintern Bros, 12: Plate 58

Mintern Bros, 12: Plate 59

Mintern Bros, 12: Plate 63 
Spinosella sororia var. dilatata

Spinosella sororia var. elongata

Spinosella sororia var. fruticosa

Spinosella velata

Spinther oniscoides

Spirillina ornata

Spirillina semidecorata

Spirillina vivipara

Spiroloculina asperula

Spiroloculina crenata

Spiroloculina limbata

Spiroloculina planissima

Spiroloculina planulata

Stereosoma celebense

Stereosoma celebense

Sthenelais? zetlandica

Sthenelais atlantica

Sthenelais boa

Sthenelais jeffreysi

Sthenelais jeffreysi

Sthenelais Iimicola

Strongylura arctiphylax

Stylaster gemmascens

Syrrhoë fimbriatus

Taenia lamelligera

Talorchestia tumida

Tanaella unguicillata

Teichopora clavata

Telegonus

Telegonus

Temora tenuicauda

Terebratula chilensis

Terebratula psittacea

Terebratula sowerbii

Terebratula uva

Textularia abbreviata

Textularia agglutinans

Textularia agglutinans

Textularia candeiana

Textularia conica var. corrugata

Textularia crispata

Textularia foliacea

Textularia hauerii

Textularia inconspicua

Textularia rugosa

Textularia sagittula

Textularia trochus

Thalestris australis

Thalestris ciliata

Thambema amicorum

Thoe erosa
Mintern Bros, 12: Plate 58

Mintern Bros, 12: Plate 63

Mintern Bros, 12: Plate 59 Mintern Bros, 12: Plate 59 McIntosh, 9: Plate 67

Unsigned, 20: Plate 51

Unsigned, 20: Plate 51

Unsigned, 20: Plate 51

West, 12: Plate 40

Unsigned, 20: Plate 41

Unsigned, 20: Plate 40

Unsigned, 20: Plate 41

West, 12: Plate 40

Hickson, SJ, 13: Plate 50

King, 13: Plate 45

McIntosh, 9: Plate 70

McIntosh, 9: Plate 72

McIntosh, 9: Plate 72

MicIntosh, 9: Plate 72

McIntosh, 9: Plate 73

McIntosh, 9: Plate 70

Stebbing, 12: Plate 24

Erxleben, 8: Plate 49

Stebbing, 13: Plate 5

Owen, 1: Plate 41

Stebbing, 12: Plate 39

Stebbing, 12: Plate 24

Woodward, EC, 13: Plate 31

Stone, 11: Plate 81

Stone, 11: Plate 82

Brady, 15: Plate 9

Owen, 1: Plate 22

Owen, 1: Plate 22

Owen, 1: Plate 22

Owen, 1: Plate 22

West, 12: Plate 42

West, 12: Plate 41

West, 12: Plate 42

Unsigned, 20: Plate 47

Unsigned, 20: Plate 47

Unsigned, 20: Plate 47

Unsigned, 20: Plate 47

Unsigned, 20: Plate 47

Unsigned, 20: Plate 47

Unsigned, 20: Plate 47

West, 12: Plate 42

Unsigned, 20: Plate 47

Brady, 15: Plate 12

Brady, 15: Plate 11

Stebbing, 20: Plate 26

Westwood, 2: Plate 9 
Thuiaria hippuris

Thuiaria laxa

Thuiaria salicornia

Trachyleberis scabrocuneata

Trachyleberis scabrocuneata

Trevelyana bicolor Trichina spiralis

Tritaxeopus cornutus Trochammina ochracea

Truncatulina

Truncatulina echinata

Truncatulina glabra

Truncatulina lobatula

Truncatulina lobatula

Truncatulina mundula

Truncatulina reticulata

Truncatulina rostrata

Truncatulina tubulifera

Truncatulina variabilis

Tyche lamellifrons

Umbonula bartonense

Umbonula calcariformis

Unio pictorum

Urothoe brevicornis

Urothoe brevicornis

Urothoe elegans

Urothoe marinus

Urothoe norvegica

Urothoe pulchella

Uvigerina asperula

Uvigerina pygmaea

Valvulina conica

Valvulina conica

Vauntompsonia arabica

Venerupis pullastra

Verneuilina spinulosa

Virgulina schreibersiana

Virgulina schreibersiana var. carinata

Webbina clavata

Xestoleberis compressa

Xestoleberis depressa

Xestoleberis luxata

Xestoleberis olivacea

Zygosiphon mortenseni
Smit, 8: Plate 65

Smit, 8: Plate 65

Smit, 8: Plate 65

Brady, 14: Plate 47

Brady, 14: Plate 47

Williams, 5: Plate 29

Owen, 1: Plate 41

Erxleben, 11: Plate 23

Unsigned, 20: Plate 46

West, 12: Plate 45

Unsigned, 20: Plate 53

Unsigned, 20: Plate 52

West, 12: Plate 42

West, 12: Plate 45

West, 12: Plate 45

West, 12: Plate 45

Unsigned, 20: Plate 52

Unsigned, 20: Plate 52

West, 12: Plate 45

Westwood, 2: Plate 12

Woodward, EC, 13: Plate 31

Woodward, EC, 13: Plate 31

Garner, 2: Plate 20

Stebbing, 13: Plate 3

Stebbing, 13: Plate 4

Stebbing, 13: Plate 1

Stebbing, 13: Plate 2

Stebbing, 13: Plate 4

Stebbing, 13: Plate 4

West, 12: Plate 45

West, 12: Plate 45

West, 12: Plate 41

West, 12: Plate 42

Calman, 18: Plate 7

Garner, 2: Plate 19

West, 12: Plate 42

Unsigned, 20: Plate 49

Unsigned, 20: Plate 49

West, 12: Plate 42

Brady, 14: Plate 46

Brady, 10: Plate 66

Brady, 14: Plate 46

Brady, 14: Plate 46

Calman, 18: Plate 7 
Achatina schweinfurthi

$$
\text { var. }
$$

Antinous anthropoophagorum

Bairdia amygdaloides

Bairdia bosquetiana

Bairdia crosskeiana

Bairdia fusca

Bairdia ovata

Bairdia subdeltoidea

Calyptraea arenata

Calyptraea cepacea

Calyptraea conica

Calyptraea cornea

Calyptraea corrugata

Calyptraea dilatata

Calyptraea dorsata

Calyptraea echinus

Calyptraea excavata

Calyptraea foliacea

Calyptraea hispida

Calyptraea hystrix

Calyptraea imbricata

Calyptraea incurva

Calyptraea lessonii

Calyptraea lichen

Calyptraea lignaria

Calyptraea maculata

Calyptraea mamillaris

Calyptraea marginalis

Calyptraea pallida

Calyptraea radiata

Calyptraea rudis

Calyptraea serrata

Calyptraea sordida

Calyptraea spinosh

Calyptraea squama

Calyptraea striata

Calyptraea strigata

Calyptraea tenuis

Calyptraea unguiformis

Calyptraea unguis

Calyptraea varia

Chama corrugata

Chama echinata

Chama frondosa

Chama imbricata

Chama lobata

Chama pacifica

Chama pellucida

Chama producta

Chama sinuosa

Chama sordida

Chama spinosa
Green, 19: Plate 1

Kobson, 20: Plate 33

Brady, 5: Plate 57

Brady, 5: Plate 57

Brady, 5: Plate 57

Brady, 5: Plate 57

Brady, 5: Plate 57

Brady, 5: Plate 57

Sowerby, GB II, 1: P1. 29

Sowerby, GB II, 1: P1. 27

Sowerby, GB II, 1: Pl. 28

Sowerby, GB II, 1: Pl. 27

Sowerby, GB II, 1: Pl. 27

Sowerby, GB II, 1: P1. 28

Sowerby, GB II, 1: P1. 28

Sowerby, GB II, 1: P1. 29

Sowerby, GB II, 1: P1. 29

Sowerby, GB II, 1: P1. 28

Sowerby, GB II, 1: P1. 27

Sowerby, GB II, 1: P1. 29

Sowerby, GB II, 1: P1. 27

Sowerby, GB II, 1: Pl. 29

Sowerby, GB II, 1: P1. 29

Sowerby, GB II, 1: P1. 28

Sowerby, GB II, 1: P1. 27

Sowerby, GB II, 1: P1. 27

Sowerby, GB II, 1: P1. 28

Sowerby, GB II, 1: P1. 29

Sowerby, GB II, 1: P1. 29

Sowerby, GB II, 1: P1. 27

Sowerby, GB II, 1: P1. 27

Sowerby, GB II, 1: P1. 28

Sowerby, GB II, 1: P1. 28

Sowerby, GB II, 1: P1. 28

Sowerby, GB II, 1: P1. 29

Sowerby, GB II, 1: P1. 28

Sowerby, GB II, 1: P1. 28

Sowerby, GB II, 1: P1. 27

Sowerby, GB II, 1: P1. 29

Sowerby, GB II, 1: P1. 28

Sowerby, GB II, 1: PI. 27

Unsigned, 1: Plate 38

Unsigned, 1: Plate 39

Unsigned, 1: Plate 38

Unsigned, 1: Plate 39

Unsigned, 1: Plate 38

Unsigned, 1: Plate 39

Unsigned, 1: Plate 38

Unsigned, 1: Plate 39

Unsigned, 1: Plate 38

Unsigned, 1: Plate 39

Unsigned, 1: Plate 38 
Chronos sublimis

Clavagella elongata

Clavagella melitensis

Cypridina bairdii

Cypridina elongata

Cypridina japonica

Cythere areolata

Cythere canaliculata

Cythere catenata

Cythere clathrata

Cythere clathrata var. latimarginata

Cythere clathrata var. lyrata

Cythere clathrata var. nuda

Cythere compacta

Cythere costata

Cythere cribriformis

Cythere hodgii

Cythere jurinei

Cythere jurinei var. costellata

Cythere lactea

Cythere lactea var. rudis

Cythere latissima

Cythere mamillata

Cythere mutabilis

Cythere normani

Cythere oblonga

Cythere parkeri

Cythere pavonia

Cythere plicatula

Cythere producta

Cythere pumicosa

Cythere pumila

Cythere rhomboidea

Cythere scabra

Cythere septentrionalis

Cythere setosa Hunde

Cythere setosa

var. hunde

Cythere venata

Cythereis batei

Cythereis cristatella

Cythereis fungoides

Cythereis lacerata

Cythereis militaris

Cythereis spinosissima

Cythereis subcoronata

Cytherella beyrichi

Cytherella pulchra

Cytherella punctata

Cytherella rugosa
Robson, 20: Plate 33

Sowerby, G.B., 1: Plate 35

Sowerby, G.B., 1: Plate 35

Brady, 5: Plate 62

Brady, 5: Plate 62

Brady, 5: Plate 62

Brady, 5: Plate 62

Brady, 5: Plate 59

Brady, 5: Plate 60

Brady, 5: Plate 59

Brady, 5: Plate 59

Brady, 5: Plate 59

Brady, 5: Plate 59

Brady, 5: Plate 62

Brady, 5: Plate 60

Brady, 5: Plate 61

Brady, 5: Plate 59

Brady, 5: Plate 59

Brady, 5: Plate 59

Brady, 5: Plate 60

Brady, 5: Plate 60

Brady, 5: Plate 62

Brady, 5: Plate 59

Brady, 5: Plate 59

Brady, 5: Plate 61

Brady, 5: Plate 59

Brady, 5: Plate 62

Brady, 5: Plate 61

Brady, 5: Plate 60

Brady, 5: Plate 59

Brady, 5: Plate 61

Brady, 5: Plate 60

Brady, 5: Plate 62

Brady, 5: Plate 61

Brady, 5: Plate 60

Brady, 5: Plate 58

Brady, 5: Plate 58

Brady, 5: Plate 59

Brady, 5: Plate 60

Brady, 5: Plate 61

Brady, 5: Plate 61

Brady, 5: Plate 61

Brady, 5: Plate 61

Brady, 5: Plate 60

Brady, 5: Plate 60

Brady, 5: Plate 57

Brady, 5: Plate 57

Brady, 5: Plate 57

Brady, 5: Plate 57 
Cytheridea curta

Cytheridea kirkbyi

Cytheridea margaritea

Cytheridea minima

Cytheridea mülleri

Cytheridea papillosa

Cytherideis decora

Cytherideis gracilis

Cytherideis lata

Cytherideis maculata

Cytherideis nobilis

Cytherideis oryza

Cytherideis pulchra

Cytherideis tigrina

Heterodesmus adamsii

Homorus bicolor

Homorus fuscostrigatus

Jonesia simplex

Leptoconchus striatus

Limicolaria saturata

Limicolaria smithi

Normania affinis

Normania avellana

Normania dorso-tuberculata

Normania glabra

Normania grisea

Normania modesta

Papuina lituus

Papuina wollastoni

Trachycystis?

ruwenzoriensis

Trochozonites leptaleus
Brady, 5: Plate 58

Brady, 5: Plate 58

Brady, 5: Plate 58

Brady, 5: Plate 58

Brady, 5: Plate 58

Brady, 5: Plate 58

Brady, 5: Plate 57

Brady, 5: Plate 58

Brady, 5: Plate 58

brady, 5: Plate 57

Brady, 5: Plate 58

Brady, 5: Plate 58

Brady, 5: Plate 58

Brady, 5: Plate 58

Brady, 5: Plate 62

Green, 19: Plate 1

Green, 19: Plate 1

Brady, 5: Plate 57

Sowerby, G.B., 1: Plate 35

Green, 19: Plate 1

Green, 19: Plate 1

Brady, 5: Plate 61

Brady, 5: Plate 61

Brady, 5: Plate 61

Brady, 5: Plate 61

Brady, 5: Plate 61

Brady, 5: Plate 61

Robson, 20: Plate 33

Robson, 20: Plate 33

Green, 19: Plate 1

Green, 19: Plate 1 
antelope antelope

aye-aye

aye-aye

aye-aye

aye-aye

aye-aye

bat

bat

bat

caaing whale

chimpanzee

chimpanzee

chimpanzee

chimpanzee

chimpanzee

chimpanzee

chinchilla

dolphin

dolphin, Risso's

duck-billed platypus

duck-billed platypus

giraffe

gorilla

gorilla

kangaroo

kangaroo,

kangaroo,

kangaroo,

kangaroo,

kangaroo,

kangaroo,

kangaroo,

kangaroo,

kangaroo,

kangaroo,

kangaroo,

kangaroo,

kangaroo,

kangaroo,

kangaroo,

kangaroo,

lion

manatee

manatee

manatee

okapi

okapi

okapi

orang utan

orang utan

orang utan

orang utan
Hills, 1: Plate 1

Unsigned, 2: Plate 39

Wolf, J., 5: Plate 14

Wolf, J., 5: Plate 15

Wolf, J., 5: Plate 16

Wolf, J., 5: Plate 17

Wolf, J., 5: Plate 18

Lear, 2: Plate 6

P., C.M., 19: Plate 20

Smit, J., 14: Plate 30

Berjeau, 8: Plate 30

Owen, 1: Plate 48

Owen, 1: Plate 50

Owen, 1: Plate 56

Scharf, 1: Plate 51

Scharf, 1: Plate 52

Scharf, 1: Plate 55

Lear, E., 1: Plate 4

Smit, 11: Plate 1

Smit, 8: Plate 1

Bennett, 1: Plate 34

Jones, R., 1: Plate 32

Hills, 3: Plate 1

Wolf, J., 5: Plate 43

Wolf, J., 5: Plate 44

Lear, E., 1: Plate 37

Frohawk, 21: Plate 35

Frohawk, 21: Plate 36

Frohawk, 21: Plate 38

Frohawk, 21: Plate 39

Frohawk, 21: Plate 40

Frohawk, 21: Plate 41

Frohawk, 21: Plate 42

Frohawk, 21: Plate 43

Frohawk, 21: Plate 44

Frohawk, 21: Plate 45

Frohawk, 21: Plate 46

Frohawk, 21: Plate 47

Frohawk, 21: Plate 48

Frohawk, 21: Plate 49

Frohawk, 21: Plate 50

Unsigned, 21: Plate 37

Lear, E., 1: Plate 24

Berjeau, 11: Plate 5

Berjeau, 11: Plate 6

Berjeau, 11: Plate 7

Grönvold, 16: Plate 31

Grönvold, 16: Plate 32

Smit, P.J., 16: Plate 30

Owen, 1: Plate 49

Owen, 1: Plate 50

Owen, 1: Plate 56

Scharf, 1: Plate 53 
orang utan

orang utan

orang utan

orang utan

orang utan

orang utan

orang utan

pigmy whale

pigmy whale

pigmy whale

rhinoceros

rhinoceros

rhinoceros

rhinoceros

rhinoceros

Risso's dolphin

sea lion

sea lion

sea-lion, Californian

sea-lion, Californian

squirrel

whale, caaing

whale, pigmy

whale, pigmy

whale, pigmy

Aigocerus niger

Alactaga

Antilope mhorr

Archaeolemur edwardsi

Archaeolemur edwardsi

Archaeolemur edwardsi

Archaeolemur edwardsi

Archaeolemur edwardsi

Archaeolemur platyrrhinus

Archaeolemur platyrrhinus

Arvicanthis macculus

Batomys granti

Batomys granti

Berardius arnouxi

Berardius arnouxi

Berardius arnouxi

Bos

Bradypus tridactylus

Callithrix moloch

Camelopardalis giraffa

Camelopardalis giraffa

Camelopardalis giraffa

Camelopardalis giraffa

Camelopardalis giraffa

Camelopardalis giraffa

Camelopardalis giraffa

Camelopardalis giraffa

Canis vulpes

Carpomys melanurus

Carpomys melanurus
Scharf, 1: Plate 54

Scharf, 1: Plate 55

Scharf, G., 2: Plate 30

Scharf, G., 2: Plate 31

Scharf, G., 2: Plate 32

Scharf, G., 2: Plate 33

Scharf, G., 2: Plate 34

Berridge, 16: Plate 7

Berridge, 16: Plate 8

Berridge, 16: Plate 9

Wolf, 9: Plate 95

Wolf, 9: Plate 96

Wolf, 9: Plate 97.

Wolf, 9: Flate 98

Wolf, 9: Plate 99

Smit, 8: Plate 1

Smit, J., 12: Plate 64

Smit, J., 12: Plate 65

Smit, 11: Plate 48

Smit, 11: Plate 49

P., C.M., 19: Plate 22

Berjeau, 8: Plate 30

Berridge, 16: Plate 7

Berridge, 16: Plate 8

Berridge, 16: Plate 9

Unsigned, 2: Plate 39

Unsigned, 2: Plate 24

hills, 1: Plate 1

Searle, 18: Plate 16

Searle, 18: Plate 17

Searle, 18: Flate 18

Searle, 18: Plate 20

Searle, 18: Plate 23

Searle, 18: Plate 19

Searle, 18: Plate 20

P., C.M., 19: Plate 24

Grönvold, 14: Plate 36

Smit, J., 14: Plate 33

Wesley, 8: Plate 27

Wesley, 8: Plate 28

Wesley, 8: Plate 29

B., E.M., 10: Plate 18

Be11, 1: Plate 17

Flower, 5: Plate 27

Hills, 3: Plate 1

Scharf, G., 2: Plate 40

Scharf, G., 2: Plate 41

Scharf, G., 2: Plate 42

Scharf, G., 2: Plate 44

Scharf, G., 3: Plate 2

Scharf, H., 2: Plate 43

Scharf, H., 2: Plate 45

B., E.M., 10: Plate 3

Grönvold, 14: Plate 36

Smit, J., 14: Plate 34 
Carpomys phaeurus

Carpomys phaeurus

Cavia aperea

Cavia porcellus

Celaenomys silaceus

Celaenomys silaceus

Centetes ecaudatus

Ceratorhinus sumatrensis

Ceratorhinus sumatrensis

Cervus belgrandi

Cervus cashmeerianus

Cervus dama

Cervus davidianus

Cervus duvaucelli

Cervus eldi

Cervus eldi

Cervus elephus

Cervus elephus var. barbarus

Cervus elephus var. barbarus?

Cervus mantchuricus

Cervus maral

Cervus maral

Cervus sika

Cervus swinhoii

Cervus taivanus

Cervus taivanus

Chinchilla lanigera

Chinchilla lanigera

Chiromys madagascariensis

Chiromys madagascariensis

Chiromys madagascariensis

Chiromys madagascariensis

Chiromys madagascariensis

Chiromys madagascariensis

Chiromys madagascariensis

Chiromys madagascariensis

Chiromys madagascariensis

Chiromys madagascariensis

Chiromys madagascariensis

Chiromys madagascariensis

Chiromys madagascariens is

Chrotomys whiteheadi

Chrytomys whiteheadi

Crateromys schadenbergi

Crtptoprocta ferox

Crunomys fallax

Crunomys fallax

Ctenodactylus massonii

Ctenomys magellanicus

Cynictis steedmannii

Dactylopsila trivirgata

Dasypus peba

Dasypus sexcinctus
Grönvold, 14: Plate 36

Smit, J., 14: Plate 34 Matthews, 5: Plate 50

Unsigned, 21: Plate 20

Grönvold, 14: Plate 35

Smit, J., 14: Plate 31

Matthews, 5: Plate 50

Smit, 10: Plate 70

Smit, 11: Plate 20

Wilson, 15: Plate 21

Smit, 7: Plate 30

B., E.M., 10: Plate 19

Smit, 7: Plate 28

Wolf, 7: Plate 36

Smit, 7: Plate 38

Wolf, 7: Plate 37

B., E.M., 10: Plate 21

B., E.M., 10: Plate 21

Dinkel, 10: Plate 20

Smit, 7: Plate 32

Wolf, 7: Plate 29

Wolf, 7: Plate 31

Wolf, 7: Plate 35

Wolf, 7: Plate 39

Smit, 7: Plate 34

Wolf, 7: Plate 33

Martin, 1: Plate 5

Newton, 1: Plate 7

Erxleben, 5: Plate 19

Erxleben, 5: Plate 20

Erxleben, 5: Plate 21

Erxleben, 5: Plate 22

Erxleben, 5: Plate 23

Erxleben, 5: Plate 24

Erxleben, 5: Plate 25

Erxleben, 5: Plate 26

Wolf, J., 5: Plate 14

Wolf, J., 5: Plate 15

Wolf, J., 5: Plate 16

Wolf, J., 5: Plate 17

Wolf, J., 5: Plate 18

Grönvold, 14: Plate 35

Smit, J., 14: Plate 32

Grönvold, 14: Plate 36

Lear, E., 1: Plate 21

Grönvold, 14: Plate 35

Smit, J., 14: Plate 33

Wagner, 7: Plate 50

Lear, 2: Plate 17

Lear, E., 1: Plate 3

Unsigned, 21: Plate 20

Owen, 4: Plate 40

Owen, 4: Plate 40 
Dasyurus

Delphinus (Lagenorhynchus) fusiformis

Delphinus delphis

Delphinus euphrosine

Delphinus fusiformis

Delphinus gadamu

Delphinus gadamu

Delphinus lentiginosus

Delphinus maculiventer

Delphinus pomeegra

Delphinus pomeegra

Delphinus sinensis

Delphinus sinensis

Delphinus tursio

Dendrolagus bennettianus

Dendrolagus dorianus $a b .10 c$. aureus

Dendrolagus dorianus dorianus

Dendrolagus dorianus mayri

Dendrolagus dorianus notatus

Dendrolagus goodfellowi goodfellowi

Dendrolagus goodfellowi shawmayeri

Dendrolagus inustus finschi

Dendrolagus inustus inustus

Dendrolagus inustus keiensis

Dendrolagus inustus keiensis

Dendrolagus leucogenys

Dendrolagus lumholtzi

Dendrolagus matschiei matschiei

Dendrolagus matschiei matschiei

Dendrolagus maximus

Dendrolagus ursinus

Dendrolagus ursinus

Didus?

Didus ineptus

Dipus hirtipes

Echinops telfairi

Elephas

Elephas falconeri

Elephas falconeri

Elephas falconeri

Elephas falconeri

Elephas falconeri
Scharf, G., 2: Plate 70

Erxleben, 6: Plate 7

Smit, 11: Plate 1

Erxleben, 6: Plate 8

Willis, 6: Plate 5

Erxleben, 6: Plate 4

Willis, 6: Plate 3

Willis, 6: Plate 5

Willis, 6: Plate 6

Erxleben, 6: Plate 8

Will is, 6: Plate 6

Smit, 7: Plate 17.

Smit, 7: Plate 18

Smit, 11: Plate 1

Frohawk, 21: Plate 49

Frohawk, 21: Plate 40

Frohawk, 21: Plate 39

Frohawk, 21: Plate 42

Frohawk, 21: Plate 41

Unsigned, 21: Plate 37

Frohawk, 21: Plate 38

Frohawk, 21: Plate 46

Frohawk, 21: Plate 45

Frohawk, 21: Plate 47

Frohawk, 21: Plate 48

see Dendrolagus ursinus

Frohawk, 21: Plate 50

Frohawk, 21: Plate 35

Frohawk, 21: Plate 36

see Dendrolagus inustus inustus

Frohawk, 21: Plate 43

Frohawk, 21: Plate 44

Ford, 4: Plate 55

Jennens, 4: Plate 54

Unsigned, 2: Plate 24

Dickes, 2: Plate 46

Erxleben, 6: Plate 44

Erxleben, 6: Plate 47

Erxleben, 6: Plate 49

Erxleben, 6: Plate 50

Erxleben, 6: Plate 51

Erxleben, 6: Plate 52 
Elephas falconeri?

Elephas indicus

Elephas indicus

Elephas melitensis

Elephas melitensis

Elephas melitensis

Elephas melitensis

Elephas melitensis

Elephas melitensis

Elephas melitensis

Elephas melitensis

Elephas melitensis

Elephas melitensis

Elephas melitensis

Elephas melitensis

Elephas melitensis

Elephas melitensis

Elephas melitensis

Elephas melitensis

Elephas melitensis

Elephas melitensis

Elephas melitensis

Elephas melitensis

Elephas melitensis

Elephas melitensis

Elephas melitensis

Elephas melitensis?

Elephas mnaidriensis

Elephas mnaidriensis

Elephas mnaidriensis

Elephas mnaidriensis

Elephas mnaidriensis

Elephas mnaidriensis

Elephas mnaidriensis

Elephas mnaidriensis

Elephas mnaidriensis

Elephas mnaidriensis

Elephas mnaidriensis

Elephas mnaidriensis

Elephas mnaidriensis

Elephas mnaidriensis

Elephas mnaidriensis

Elephas mnaidriensis

Elephas mnaidriensis

Equus caballus

Equus caballus

Equus caballus

Equus caballus

Euphysetes simus

Felidae caligata

Felidae pardina

Felidae pardus

Felis domestica

Felis domestica

Felis jubata
Erxleben, 6: Plate 53

Howe, 11: Plate 21

Howe, 11: Plate 22

Erxleben, 6: Plate 45

Erxleben, 6: Plate 46

Erxleben, 6: Plate 47

Erxleben, 6: Plate 48

Erxleben, 6: Plate 51

Griesbach, 9: Plate 1

Griesbach, 9: Plate 11

Griesbach, 9: Plate 12

Griesbach, 9: Plate 13

Griesbach, 9: Plate 14

Griesbach, 9: Plate 15

Griesbach, 9: Plate 2

Griesbach, 9: Plate 21

Griesbach, 9: Plate 4

Griesbach, 9: Plate 5

Griesbach, 9: Plate 9

Wesley, 9: Plate 10

Wesley, 9: Plate 16

Wesley, 9: Plate 17

Wesley, 9: Plate 18

Wesley, 9: Plate 19

Wesley, 9: Plate 20

Wesley, 9: Plate 6

Erxleben, 6: Plate 53

Griesbach, 9: Plate 1

Griesbach, 9: Plate 11

Griesbach, 9: Plate 14

Griesbach, 9: Plate 15

Griesbach, 9: Plate 2

Griesbach, 9: Plate 21

Griesbach, 9: Plate 3

Griesbach, 9: Plate 4

Griesbach, 9: Plate 8

Wesley, 9: Plate 10

Wesley, 9: Plate 16

Wesley, 9: Plate 17

Wesley, 9: Plate 18

Wesley, 9: Plate 19

Wesley, 9: Plate 20

Wesley, 9: Plate 6

Wesley, 9: Plate 7

B., E.M., 10: Plate 18

B., E.M., 10: Plate 7

B., E.M., 10: Plate 8

B., E.M., 10: Plate 9

see Physeter simus

B., E.M., 10: Plate 3

B., E.M., 10: Plate 3

B., E.M., 10: Plate 3

Flower, 5: Plate 27

Jones, T.R., 1: Plate 20

Jones, T.R., 1: Plate 20 
Felis leo goojratensis

Funisciurus antoniae

Funisciurus carruthersi

Galago crassicaudatus

Galago crassicaudatus

Galago crassicaudatus

Galago crassicaudatus

Galago crassicaudatus

Galago moholi

Galeopithecus

philippinensis

Galeopithecus temminckii

Galictis allamandi

Galictis vittata

Galictis vittata

Gerbillus sp.?

Gerbillus africanus

Gerbillus brevicaudatus

Gerbillus burtoni

Gerbillus burtoni

Gerbillus egyptius

Gerbillus indicus

Gerbillus otarius

Gerbillus pygargus

Gerbillus pyramidum

Globiocephalus melas

Globiocephalus melas

Globiocephalus melas

Globiocephalus melas

Globiocephalus melas

Globiocephalus melas

Globiocephalus melas

Globiocephalus melas

Globiocephalus melas

Grampus griseus

Grampus griseus

Harpyionycteris whiteheadi

Harpyionycteris whiteheadi

Hippopotamus (?)

Hippopotamus?

Hippopotamus amphibius

Hippopotamus amphibius

Homo

Homo

Homo

Homo

Homo

Homo

Homo

Homo

Homo

Homo

Homo

Homo

Homo var. ethiopicus
Lear, E., 1: Plate 24

P., C.M., 19: Plate 23

P., C.Ni., 19: Plate 22

Berjeau, 7: Plate 2

Berjeau, 7: Plate 3

Berjeau, 7: Plate 4

Berjeau, 7: Plate 5

Berjeau, 7: Plate 6

Unsigned, 21: Plate 20

Curtis, 2: Plate 58

Curtis, 2: Plate 58

Unsigned, 2: Plate 37

Unsigned, 2: Plate 35

Unsigned, 2: Plate 36

Unsigned, 2: Plate 26

Unsigned, 2: Plate 26

Unsigned, 2: Plate 26

Unsigned, 2: Plate 22

Unsigned, 2: Plate 23

Unsigned, 2: Plate 25

Unsigned, 2: Plate 25

Unsigned, 2: Plate 26

Unsigned, 2: Plate 25

Unsigned, 2: Plate 25

Berjeau, 8: Plate 30

Berjeau, 8: Plate 31

Berjeau, 8: Plate 32

Berjeau, 8: Plate 33

Berjeau, 8: Plate 34

Berjeau, 8: Plate 35

Berjeau, 8: Plate 36

Berjeau, 8: Plate 37

Berjeau, 8: Plate 38

Smit, 8: Plate 1

Wesley, 8: Plate 2

Grönvold, 14: Plate 35

Smit, J., 14: Plate 30

Griesbach, 9: Plate 11

Erxleben, 6: Plate 51

Smit, 11: Plate 3

Smit, 11: Plate 4

Erxleben, 5: Plate 1

Erxleben, 5: Plate 2

Erxleben, 5: Plate 3

Erxleben, 5: Plate 4

Erxleben, 5: Plate 5

Erxleben, 5: Plate 9

Ford, 5: Plate 12

Ford, 5: Plate 13

Ford, 5: Plate 7

Ford, 5: Plate 8

Robinson, F., 5: Plate 10

Robinson, F., 5: Plate 11

Erxleben, 5: Plate 6 
Homo sapiens

Homo sapiens

Homo sapiens

Homo sapiens

Homo sapiens

Homo sapiens

Homo sapiens var. aethiopicus

Homo sapiens var. aethiopicus

Homo sapiens var. aethiopicus

Homo sapiens var. melanoides

Hyaena brunnea

Hyena crocuta

Hyena crocuta

Hylomys peguens is

Hyperoodon

Hyperoodon rostratus

Hypsiprymnus

Ibex

Ibex

Ibex

Ibex

Ibex

Ibex

Inia geoffrensis

Inia geoffrensis

Inia geoffrensis

Lagotis cuvieri

Lagotis cuvieri

Lagotis cuvieri

Lagotis pallipes

Leggada bufo

Lemur jullyi

Lemur majori

Lemur nigrifrons

Lenomys meyeri

Lepus cuniculus

Lophuromys woosnami

Macacus nemestrinus

Macropus

Macropus (Osphranter) rufus

Macropus (Osphranter) rufus

Macropus (Osphranter) rufus

Macropus (Osphranter) rufus

Macropus (Osphranter) rufus

Macropus (Osphranter) rufus
Erxleben, 4: Plate 32

Erxleben, 4: Plate 36

Ford, 4: Plate 31

Scharf, 1: Plate 57

Scharf, 1: Plate 58

Unsigned, 21: Plate 20

Erxleben, 4: Plate 33

Erxleben, 4: Plate 34

Erxleben, 4: Plate 35

Ford, 4: Plate 30

Berjeau, 7: Plate 63

Dinke1, 10: Plate 1

Dinkel, 10: Plate 2

Ahmud, 8: Plate 64

Smit, 6: Plate 56

Wesley, 8: Plate 29

Scharf, G., 2: Plate 71

B., E.M., 10: Plate 23

B., E.M., 10: Plate 24

B., E.M., 10: Plate 25

B., E.M., 10: Plate 26

Dinkel, 10: Plate 20

Dinkel, 10: Plate 22

Smit, 6: Plate 25

Smit, 6: Plate 26

Smit, 6: Plate 27

Lear, E., 1: Plate 4

Martin, 1: Plate 5

Newton, 1: Plate 6

Zeitter, 1: Plate 42

P., C.M., 19: Plate 23

Searle, 18: Plate 27

Searle, 18: Plate 28

Flower, 5: Plate 27

Grönvold, 14: Plate 36

Matthews, 5: Plate 50

P., C.M., 19: Plate 24

Matthews, 5: Plate 50

Scharf, G., 2: Plate 71

Erxleben, 9: Plate 74

Erxleben, 9: Plate 75

Erxleben, 9: Plate 76

Erxleben, 9: Plate 77

Erxleben, 9: Plate 78

Erxleben, 9: Plate 79 
Macropus (Osphranter) rufus

Macropus (Osphranter) rufus

Macropus (Osphranter) rufus

Macropus (Osphranter) rufus

Macropus parryie

Manatus americanus

Manatus americanus

Manatus americanus

Manatus americanus

Manatus americanus

Manatus americanus

Manatus americanus

Manatus americanus

Manatus americanus

Manatus americanus

Manatus americanus

Manatus americanus

Manatus americanus

Manatus americanus

Megaladapis grandidieri

Megaladapis grandidieri

Megaladapis grandidieri

Meles labradoria

Meles taxus

Mesoplodon australis

Mesoplodon australis

Mesoplodon australis

Mesoplodon grayi

Mesoplodon grayi

Mesoplodon grayi

Mesoplodon haasti

Mesoplodon haasti

Mesoplodon hectori

Mesoplodon hectori

Mesopropithecus

$$
\text { pithecoides }
$$

Mesopropithecus pithecoides

Mesopropithecus pithecoides

Mungos sanguineus proteus

Mus decumanus

Mus luzonicus

Myosorex blarina

Myoxus melitensis

Myrmecobius fasciatus

Myrmecobius fasciatus

Myrmecophaga didactyla

Myrmecophaga jubata

Myrmecophaga jubata

Myrmecophaga jubata
Erxleben, 9: Plate 80

Erxleben, 9: Plate 81

Erxleben, 9: Plate 82

Erxleben, 9: Plate 83

Lear, E., 1: Plate 37

Berjeau, 11: Plate 5

Berjeau, 11: Plate 6

Berjeau, 11: Plate 7

Berjeau, 11: Plate 8

Berjeau, 11: Plate 9

Berjeau, 8: Plate 21

Berjeau, 8: Plate 22

Berjeau, 8: Plate 23

Berjeau, 8: Plate 24

Berjeau, 8: Plate 25

Berjeau, 8: Plate 26

Smit, 10: Plate 28

Smit, 10: Plate 29

Smit, 10: Plate 30

Searle, 18: Plate 24

Searle, 18: Flate 25

Searle, 18: Plate 26

Scharf, G., 2: Plate 59

B., E.M., 10: Plate 3

Smit, 10: Plate 71

Smit, 10: Plate 72

Smit, 10: Plate 73

Smit, 10: Plate 71

Smit, 10: Plate 72

Smit, 10: Plate 73

Smit, 10: Plate 71

Smit, 10: Plate 72

Smit, 10: Plate 71

Smit, 10: Plate 72

Searle, 18: Plate 21

Searle, 18: Plate 22

Searle, 18: Plate 23

P., C.M., 19: Plate 21

Matthews, 5: Plate 50

Grönvold, 14: Plate 36

P., C.M., 19: Plate 20

Adams, 6: Plate 54

Dickes, 2: Plate 27

Waterhouse, 2: Plate 28

Owen, 4: Plate 40

Carter, E.V., 4: Plate 37

Carter, E.V., 4: Plate 38

Carter, E.V., 4: Plate 39 
Myrmecophaga jubata

Myrmecophaga jubata

Myrmecophaga jubata

Nannosciurus samaricus

Neobalaena marginata

Neobalaena marginata

Neobalaena marginata

Nyctipithecus trivirgatus

Octodon cumingii

Okapia johnstoni

Okapia johnstoni

Okapia johnstoni

Ornithorhynchus paradoxus

Ornithorhynchus paradoxus

Ornithorhynchus paradoxus

Oryctolagus cuniculus

Otaria gillespii

Otaria gillespii

Otaria gillespii

Otaria hookeri

Otaria hookeri

Otaria jubata

Otaria jubata

Otaria jubata

Otaria jubata

Otaria jubata

Otaria jubata

Otaria jubata

Otaria jubata

Otaria jubata

Otaria jubata

Otaria jubata

Otaria jubata

Otaria jubata

Palaeopropithecus maximus

Palaeopropithecus maximus

Palaeopropithecus maximus

Palaeopropithecus maximus

Palaeopropithecus maximus

Palaeopropithecus maximus

Palorchestes crassus

Pectinator spekei

Pectinator spekei

Pectinator spekii

Perameles lagotis

Petaurus

Phalangista

Phascolarctos fuscus

Phascolomys

Phascolomys latifrons

Phascolomys latifrons

Phascolomys latifrons

Phascolomys latifrons

Phascolomys latifrons

Phascolomys latifrons
Carter, H.V., 4: Plate 51

Carter, H.V., 4: Plate 52

Carter, H.V., 4: Plate 53

Smit, J., 14: Plate 30

Berridge, 16: Plate 7

Berridge, 16: Plate 8

Berridge, 16: Plate 9

Flower, 5: Plate 27

Lear, 2: Plate 16

Grönvold, 16: Plate 31

Grönvold, 16: Plate 32

Smit, P.J., 16: Plate 30

Bennett, 1: Plate 34

Jones, R., 1: Plate 32

Owen, 1: Plate 33

Unsigned, 21: Plate 20

Smit, 11: Plate 48

Smit, 11: Plate 49

Smit, 11: Plate 50

Smit, J., 12: Plate 64

Smit, J., 12: Plate 65

Berjeau, 7: Plate 67

Berjeau, 7: Plate $6 \varepsilon$

Berjeau, 7: Plate 69

Berjeau, 7: Plate 70

Berjeau, 7: Plate 71

Berjeau, 7: Plate 72

Berjeau, 7: Plate 73

Berjeau, 8: Plate 77

Berjeau, 8: Plate 78

Berjeau, 8: Plate 79

Berjeau, 8: Plate 80

Berjeau, 8: Plate 81

Berjeau, 8: Plate 82

Searle, 18: Plate 10

Searle, 18: Plate 11

Searle, 18: Plate 12

Searle, 18: Plate 13

Searle, 18: Plate 14

Searle, 18: Plate 15

Smit, 11: Plate 2

Wagner, 7: Plate 48

Wagner, 7: Plate 49

Wagner, 7: Plate 50

Scharf, G., 2: Plate 71

Scharf, G., 2: Plate 71

Scharf, G., 2: Plate 71

Unsigned, 2: Plate 69

Scharf, G., 2: Plate 71

Maclise, 3: Plate 37

Smit, 8: Plate 50

Smit, 8: Plate 51

Smit, 8: Plate 52

Smit, 8: Plate 53

Smit, 8: Plate 54 
Phascolomys latifrons Phascolomys latifrons Phascolomys latifrons Phascolomys latifrons Phascolomys latifrons Phascolomys latifrons Phascolomys latifrons Phascolomys latifrons Phascolomys latifrons Phascolomys platyrhinus Phascolomys platyrhinus Phascolomys platyrhinus Phascolomys platyrhinus Phascolomys platyrhinus Phascolomys platyrhinus Phascolomys platyrhinus Phascolomys platyrhinus Phascolomys platyrhinus Phascolomys platyrhinus Phascolomys platyrhinus Phascolomys platyrhinus Phascolomys platyrhinus Phascolomys vombatus Phascolomys vombatus Phascolomys vombatus Phascolomys vombatus Phascolomys vombatus Phascolomys vombatus Phascolomys vombatus Phascolomys vombatus Phascolomys wombat

Phocoena brevirostris Physeter breviceps Physeter macrocephalus Physeter macrocephalus Physeter macrocephalus Physeter macrocephalus Physeter macrocephalus Physeter macrocephalus Physeter macrocephalus Physeter macrocephalus Physeter simus

Physeter simus Physeter simus Physeter simus Physeter simus Pithecus morio Pithecus morio Pithecus satyrus Pithecus satyrus Pithecus satyrus var. pappan

Pithecus satyrus var. rambi

Pithecus wurmbii
Smit, 8: Plate 55 Smit, 8: Plate 56 Smit, 8: Plate 57 Smit, 8: Plate 69 Smit, 8: Plate 70 Smit, 8: Plate 71 Smit, 8: Plate 72 Smit, 8: Plate 73 Smit, 8: Plate 74 Smit, 8: Plate 50 Smit, 8: Plate 51 Smit, $\delta$ : Plate 52 Smit, 8: Plate 53 Smit, 8: Plate 54 Smit, 8: Plate 55 Smit, 8: Plate 56 Smit, 8: Plate 57 Smit, 8: Plate 69 Smit, 8: Plate 70 Smit, 8: Plate 71 Smit, 8: Plate 72 Smit, 8: Plate 73 Maclise, 3: Plate 37 Smit, 8: Plate 50 Smit, 8: Plate 51 Smit, 8: Plate 52 Smit, 8: Plate 54 Smit, 8: Plate 55 Smit, 8: Plate 56 Smit, 8: Plate 57 Unsigned, 2: Plate 68 Willis, 6: Plate 9 Owen, 6: Plate 14 Owen, 6: Plate 14 Smit, 6: Plate 55 Smit, 6: Plate 56 Smit, 6: Plate 57 Smit, 6: Plate 58 Smit, 6: Plate 59 Smit, 6: Plate 60 Smit, 6: Plate 61 Owen, 6: Plate 14 Willis, 6: Plate 10 Willis, 6: Plate 11 Willis, 6: Plate 12 Willis, 6: Plate 13 Ford, 4: Plate 48 Ford, 4: Plate 49 Erxleben, 4: Plate 33 Ford, 4: Plate 29

Ford, 4: Plate 50

Ford, 4: Plate 50 Erxleben, 4: Plate 33 
Pontoporia blainvillii

Potamogale velox

Potamogale velox

Potos tlavus

Pteropus whitei

Pteropus whitei

Rhinoceros bicornis

Rhinoceros hemitoechus

Rhinoceros hemitoechus

Rhinoceros hemitoechus

Rhinoceros hemitoechus

Rhinoceros hemitoechus

Rhinoceros hemitoechus

Rhinoceros hemitoechus

Rhinoceros hemitoechus

Rhinoceros hemitoechus

Rhinoceros indicus

Rhinoceros indicus

Rhinoceros indicus

Rhinoceros indicus

Rhinoceros indicus

Rhinoceros indicus

Rhinoceros indicus

Rhinoceros indicus

Rhinoceros indicus

Rhinoceros indicus

Rhinoceros indicus

Rhinoceros indicus

Rhinoceros indicus

Rhinoceros indicus

Rhinoceros lasiotis

Rhinoceros sondaicus

Rhinoceros sondaicus

Rhinoceros sondaicus

Rhinoceros sondaicus

Rhinoceros sondaicus

Rhinoceros sondaicus

Rhinoceros sumatrensis

Rhinoceros unicornis

Rhynchomys soricoides

Rhynchomys soricoides

Rousettus lanosus

Sciurus ruwenzorii

Semnopithecus entellus

Semnopithecus entellus

Simia

Simia

Simia

Simia

Simia

Simia

Simia

Simia

Simia

Simia morio
Smit, 6: Plate 28

Ford, 6: Plate 2

Wolf, 6: Plate 1

Unsigned, 21: Plate 20

Curtis, 2: Plate 7

Lear, 2: Plate 6

Wolf, 9: Plate 99

B., E.M., 10: Plate 10

B., E.M., 10: Plate 11

B., E.M., 10: Plate 12

B., E.M., 10: Plate 13

B., E.M., 10: Plate 14

B., E.M., 10: Plate 15

B., E.M., 10: Plate 16

B., E.M., 10: Plate 17

B., E.M., 10: Plate 18

Erxleben, 4: Plate 10

Erxleben, 4: Plate 11

Erxleben, 4: Plate 12

Erxleben, 4: Plate 13

Erxleben, 4: Plate 14

Erxleben, 4: Plate 15

Erxleben, 4: Plate 16

Erxleben, 4: Plate 17

Erxleben, 4: Plate 18

Erxleben, 4: Plate 19

Erxleben, 4: Plate 20

Erxleben, 4: Plate 21

Erxleben, 4: Plate 22

Erxleben, 4: Plate 9

Wolf, 9: Plate 98

Smit, J., 12: Plate 33

Smit, J., 12: Plate 34

Smit, J., 12: Plate 35

Smit, J., 12: Plate 36

Smit, J., 12: Plate 37

Wolf, 9: Plate 96

Wolf, 9: Plate 97

Wolf, 9: Plate 95

Grönvold, 14: Plate 35

Smit, J., 14: Plate 31

P., C.M., 19: Plate 20

P., C.M., 19: Plate 22

Owen, 1: Plate 8

Owen, 1: Plate 9

Wesley, 6: Plate 35

Wesley, 6: Plate 36

Wesley, 6: Plate 37

Wesley, 6: Plate 38

Wesley, 6: Plate 39

Wesley, 6: Plate 40

Wesley, 6: Plate 41

Wesley, 6: Plate 42

Wesley, 6: Plate 43

Scharf, G., 2: Plate 33 
Simia morio

Simia morio?

Simia morio?

Simia morio?

Simia morio?

Simia morio?

Simia satyrus

Simia satyrus

Simia satyrus

Simia satyrus

Simia satyrus

Simia satyrus

Simia troglodytes

Simia troglodytes

Simia troglodytes

Simia troglodytes

Simia troglodytes

Simia troglodytes

Simia wurmbii

Simia wurmbii

Simia wurmbii

Stenops javanicus

Thylacinus

Trichecus rosmarus

Trichecus rosmarus

Troglodytes calvus

Troglodytes calvus

Troglodytes calvus

Troglodytes calvus

Troglodytes calvus

Troglodytes calvus

Troglodytes gorilla

Troglodytes gorilla

Troglodytes gorilla

Troglodytes gorilla

Troglodytes gorilla

Troglodytes gorilla

Troglodytes gorilla

Troglodytes gorilla

Troglodytes gorilla

Troglodytes gorilla

Troglodytes gorilla

Troglodytes gorilla

Troglodytes gorilla

Troglodytes gorilla

Troglodytes gorilla

Troglodytes gorilla

Troglodytes gorilla

Troglodytes gorilla

Troglodytes gorilla

Troglodytes gorilla

Troglodytes gorilla

Troglodytes gorilla

Troglodytes gorilla

Troglodytes gorilla
Scharf, G., 2: Plate 34

Smit, J., 13: Plate 24

Smit, J., 13: Plate 25

Smit, J., 13: Plate 26

Smit, J., 13: Plate 27

Smit, J., 13: Plate 28

Owen, 1: Plate 49

Owen, 1: Plate 50

Owen, 1: Plate 56

Scharf, 1: Plate 53

Scharf, 1: Plate 54

Scharf, 1: Plate 55

Owen, 1: Plate 48

Owen, 1: Plate 50

Owen, 1: Plate 56

Scharf, 1: Plate 51

Scharf, 1: Plate 52

Scharf, 1: Plate 55

Scharf, G., 2: Plate 30

Scharf, G., 2: Plate 31

Scharf, G., 2: Plate 32

Flower, 5: Plate 27

Scharf, G., 2: Plate 70

Berjeau, 7: Plate 54

Berjeau, 7: Plate 55

Smit, J., 13: Plate 20

Smit, J., 13: Plate 21

Smit, J., 13: Plate 22

Smit, J., 13: Plate 23

Smit, J., 13: Plate 25

Smit, J., 13: Plate 28

Erxleben, 3: Plate 61

Erxleben, 3: Plate 62

Erxleben, 3: Plate 63

Erxleben, 4: Plate 32

Erxleben, 4: Plate 33

Erxleben, 4: Plate 34

Erxleben, 4: Plate 35

Erxleben, 4: Plate 36

Erxleben, 5: Plate 1

Erxleben, 5: Plate 2

Erxleben, 5: Plate 3

Erxleben, 5: Plate 4

Erxleben, 5: Plate 5

Erxleben, 5: Plate 6

Erxleben, 5: Plate 9

Ford, 4: Plate 26

Ford, 4: Plate 27

Ford, 4: Plate 28

Ford, 4: Plate 31

Ford, 4: Plate 32

Ford, 5: Plate 12

Ford, 5: Plate 13

Ford, 5: Plate 45

Ford, 5: Plate 47 


Troglodytes gorilla
Troglodytes gorilla
Troglodytes gorilla
Troglodytes gorilla
Troglodytes gorilla
Troglodytes gorilla
Troglodytes gorilla
Troglodytes gorilla
Troglodytes gorilla
Troglodytes niger
Troglodytes niger
Troglodytes niger
Troglodytes niger
Troglodytes niger
Troglodytes niger
Troglodytes niger
Troglodytes niger
Troglodytes niger
Troglodytes niger
Troglodytes niger
Troglodytes niger
Troglodytes niger
Troglodytes niger
Troglodytes niger
Troglodytes niger
Trogontherium cuvieri
Ursus arctos
Ursus arctos
Ursus arctos
Ziphius
Ziphius
Ziphius

Ford, 5: Plate 49

Ford, 5: Plate 7

Ford, 5: Plate 8

Robinson, F., 5: Plate 10

Kobinson, F., 5: Plate 11

Robinson, F., 5: Plate 46

Kobinson, F., 5: Plate 48

Wolf, J., 5: Plate 43

Wolf, J., 5: Plate 44

Erxleben, 3: Plate 58

Erxleben, 3: Plate 59

Erxleben, 3: Plate 60

Erxleben, 4: Plate 32

Erxleben, 4: Plate 35

Erxleben, 4: Plate 36

Erxleben, 5: Plate 1

Erxleben, 5: Plate 2

Erxleben, 5: Plate 3

Erxleben, 5: Plate 4

Erxleben, 5: Plate 5

Erxleben, 5: Plate 6

Erxleben, 5: Plate 9

Ford, 4: Plate 32

Ford, 5: Plate 7

Ford, 5: Plate 8

Berjeau, 13: Plate 19

B., E.M., 10: Plate 5

Dinkel, 10: Plate 4

Dinke1, 10: Plate 6

Parker, 12: Plate 49

Scott, 12: Plate 48

Scott, 12: Plate 50 



AMNH LIBRARY 